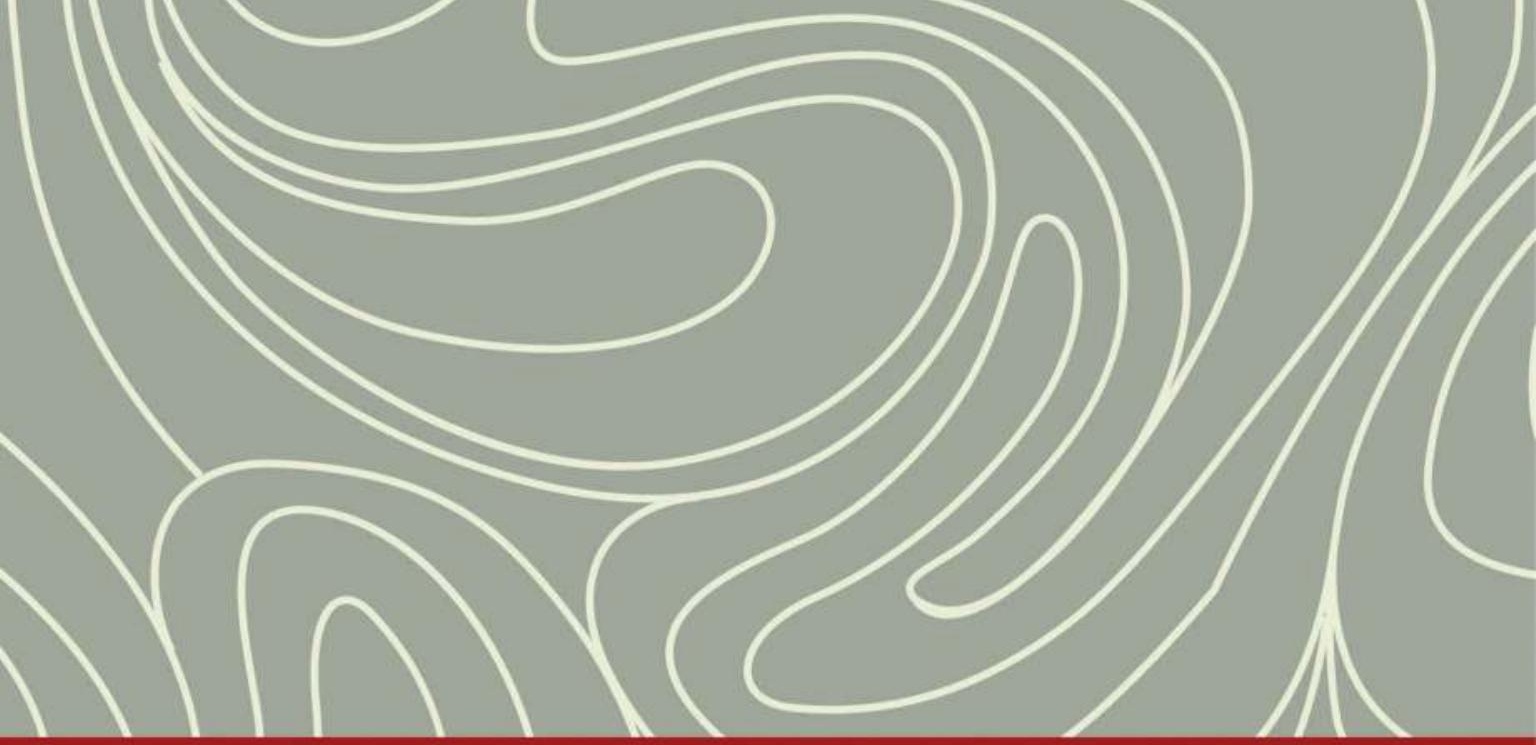

The Historical Anthropology of Chinese Society series

\title{
THE TRANSFORMATION OF YUNNAN IN MING CHINA
}

FROM THE DALI KINGDOM TO IMPERIAL PROVINCE

Edited by

Christian Daniels and Jianxiong Ma

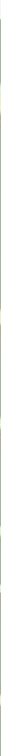




\section{The Transformation of Yunnan in Ming China}

This book examines how the Ming state transformed the multi-ethnic society of Yunnan into a province. Yunnan had remained outside the ambit of central government when ruled by the Dali kingdom, 937-1253, and its foundation as a province by the Yuan regime in 1276 did not disrupt Dali kingdom-style political, social and religious institutions. It was the Ming state in the fourteenth to seventeenth centuries, through its institutions for military and civilian control, which brought about profound changes and truly transformed local society into a province. In their investigation of the incorporation of ethnic peoples into Chinese administrative systems, authors demonstrate how diverse ethnic communities negotiated with the Ming state. In contrast to other studies which have portrayed Yunnan as a non-Han frontier region waiting to be colonised, this book, by focusing on changes in local society, casts off the idea of Yunnan as a border area far from civilisation.

Christian Daniels is Professor and Head of the Division of Humanities at Hong Kong University of Science and Technology.

Jianxiong Ma is an Associate Professor in the Division of Humanities at Hong Kong University of Science and Technology. 


\section{The Historical Anthropology of Chinese Society Series \\ Series editor: David Faure \\ Chinese University of Hong Kong}

Historians are being increasingly attracted by the methodology of historical anthropology, an approach which combines observations in the field with documentary analysis, both of official documents and of documents collected from local society. In China, historians have been pursuing such local historical research for a generation, with very little of this work being available in English hitherto. This series makes available in English research undertaken by the Historical Anthropology of Chinese Society project based at the Chinese University of Hong Kong, and related work. The books argue that top-heavy, dynasty-centred history is incomplete without an understanding of how local communities were involved in the government process and in the creation of their own historical narratives. The books argue that Chinese social history needs to be rewritten from the bottom up.

1 The Fisher Folk of Later Imperial and Modern China

An Historical Anthropology of Boat-and-Shed Living

Edited by Xi He and David Faure

2 Colonial Administration and Land Reform in East Asia

Edited by Sui-Wai Cheung

3 Fieldwork in Modern Chinese History

A Research Guide

Edited by Thomas David DuBois and Jan Kiely

4 The Transformation of Yunnan in Ming China

From the Dali Kingdom to Imperial Province

Edited by Christian Daniels and Jianxiong Ma

For more information about this series, please visit: www.routledge.com/TheHistorical-Anthropology-of-Chinese-Society-Series/book-series/HISTANTHCH INSOC 


\section{The Transformation of Yunnan in Ming China}

From the Dali Kingdom to

Imperial Province

\section{Edited by Christian Daniels and Jianxiong Ma}

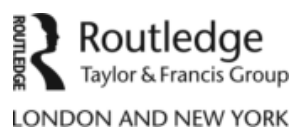


First published 2020

by Routledge

2 Park Square, Milton Park, Abingdon, Oxon OX14 4RN

and by Routledge

52 Vanderbilt Avenue, New York, NY 10017

Routledge is an imprint of the Taylor \& Francis Group, an informa business

(C) 2020 selection and editorial matter, Christian Daniels and Jianxiong $\mathrm{Ma}$; individual chapters, the contributors

The right of Christian Daniels and Jianxiong Ma to be identified as the authors of the editorial material, and of the authors for their individual chapters, has been asserted in accordance with sections 77 and 78 of the Copyright, Designs and Patents Act 1988.

All rights reserved. No part of this book may be reprinted or reproduced or utilised in any form or by any electronic, mechanical, or other means, now known or hereafter invented, including photocopying and recording, or in any information storage or retrieval system, without permission in writing from the publishers.

Trademark notice: Product or corporate names may be trademarks or registered trademarks, and are used only for identification and explanation without intent to infringe.

British Library Cataloguing-in-Publication Data

A catalogue record for this book is available from the British Library

Library of Congress Cataloging-in-Publication Data

A catalog record has been requested for this book

ISBN: 978-0-367-35336-0 (hbk)

ISBN: 978-0-429-33078-0 (ebk)

Typeset in Times New Roman

by Wearset Ltd, Boldon, Tyne and Wear 


\section{Contents}

List of figures vi vi

List of maps vii

List of tables viii

Notes on contributors $\quad$ ix

Acknowledgements $\quad$ xi

Introduction: the agency of local elites in the transformation of western Yunnan during the Ming dynasty

CHRISTIAN DANIELS AND JIANXIONG MA

1 Salt, grain and the change of deities in early

Ming western Yunnan

Z H A O MIN

2 Local communities, village temples and the reconstruction of ethnic groups in western Yunnan, fourteenth to seventeenth centuries

JIA N XIONG MA

3 The Lancang Guard and the construction of Ming society in northwest Yunnan

HUANG CAIWEN

4 The Mu Native Official's governance of the Tibetan world and his sponsorship of Tibetan Buddhism

Y A M ADA NORIYUKI

5 Upland leaders of the internal frontier and Ming governance of western Yunnan, fifteenth and sixteenth centuries

CHRISTIAN DANIELS 


\section{Figures}

1.1 Jiuzhou nestled beside the Mekong River encircled by Sanchong Mountain

2.1 Villages in the Dengchuan basin located along the banks of the Miju River 瀰苴河 (the line of trees in the centre)

3.1 The South Gate of the Qingshui postal relay station

4.1 The present-day sBa shes palace at Baisha 白沙, Lijiang

4.2 The reconstructed stone gate standing at the entrance to the $\mathrm{Mu}$ Native Official yamen in Lijiang

5.1 The deep gorge of the Yupao River

5.2 Sketch map of the mountains of Iron Chain Gorge 


\section{Maps}

1.1 Western Yunnan, $1582 \quad 23$

$\begin{array}{lll}2.1 & \text { Dali region, } c .1582 & 49\end{array}$

$\begin{array}{lll}3.1 & \text { Northwest Yunnan, c.1582 } & 78\end{array}$

$\begin{array}{ll}4.1 & \text { Lijiang and the Muli region } \\ 5.113\end{array}$

5.1 Internal frontier and centres of administration in western
Yunnan, 1582 


\section{Tables}

4.1 Villages and their tax quotas 119

5.1 Leaders in the internal frontier, c.1572-1573 148

5.2 Native Official troops mobilised in the 1573/74 campaign against Iron Chain Gorge 


\section{Contributors}

Christian Daniels was Professor of Chinese history at the Research Institute for Languages and Cultures of Asia and Africa, Tokyo University of Foreign Studies, Japan from 1996 to 2014. He is now Head and Professor in the Humanities Division, Hong Kong University of Science and Technology. He has published extensively in Chinese, Japanese and English about the history of Southwest China and northern mainland Southeast Asia. He guest edited the Special Issue: Upland Peoples in the Making of History in Northern Continental Southeast Asia for the international journal, Southeast Asian Studies (Vol. 2, No. 1, April 2013) published by Kyoto University. His two most recent English publications include "The Mongol-Yuan in Yunnan and ProtoTai/Tai Polities during the 13th-14th Centuries", Journal of the Siam Society (Vol. 106, 2018, pp. 201-243), and "Upland Peoples and the 1729 Qing Annexation of the Tai Polity of Sipsong Panna, Yunnan: Disintegration from the Periphery", in China and Southeast Asia: Historical Interactions edited by Geoff Wade (London and New York: Routledge, 2019), pp. 188-217.

HUANG Caiwen is Professor and Vice Dean at Nationalities Research Institute of Yunnan (Faculty of Ethnology and History), Yunnan Minzu University in Kunming, China. He researches the historical anthropology of Yunnan, and he has published in Chinese on northwest Yunnan.

Jianxiong MA is Associate Professor in the Division of Humanities at the Hong Kong University of Science and Technology. As an anthropologist, he has done long-term field work on ethnic groups in Southwest China, especially on the frontier between Yunnan and Myanmar. His books include The Lahu Minority in Southwest China: A Response to Ethnic Marginalization on the Frontier (Routledge, 2013) and Reinventing Ancestors: Ethnic Mobilization in China's Southwest Frontier and the Historical Construction of Lahu (Hong Kong: The Chinese University Press, in Chinese). His present research focuses on the historical formation of the Sino-Myanmar frontier and ecological conditions of cultural diversity and ethnicity in Southwest China. His publications on these topics include "Salt and Revenue in the Frontier Formation: State Mobilized Ethnic Politics in Yunnan-Burma Borderland since the 1720s" in Modern Asian Studies (Vol. 48, No. 6, 2014, pp. 1637-1669); 
"The Rise of Gentry Power on the China-Burma Frontier since the 1870s: The Case of the Peng Family in Mianning, Southwest Yunnan" in International Journal of Asian Studies (Vol. 11, No. 1, 2014); "The Mule Caravans as Cross-Border Networks: Local Bands and Their Stretch on the Frontier between Yunnan and Burma", co-authored with MA Cunzhao, in Myanmar's Mountain and Maritime Borderscapes: Local Practices, Boundary-making and Figured Worlds, edited by Su-Ann Oh (Singapore: ISEAS Publishing, 2016, pp. 237-257), and "Dike-based Communities between Water and Sand: The Sand-land Environmental System in Dongchong, South China, 1720s-1980s", in Environment, Modernization and Development in East Asia: Perspectives from Environmental History, edited by Ts'ui-jung Liu and James Beattie (London and New York: Palgrave, 2016, pp. 89-110).

YAMADA Noriyuki is Professor at Hokkai School of Commerce, Sapporo, Japan. He is a historian of northwest Yunnan and the Tibetan world. His main publications in Japanese include the "Territorial Expansion into Surrounding Areas by the Naxi Mu Family Native Official of Lijiang in the Ming Period 明代の雲南麗江ナシ族 木氏土司にょる周辺地域への勢力拡張とその 意義”, published in the Shigaku Zasshi 史學雜誌 (Vol. 118:7, 2009, pp. 60-86) and The History of the Political Regime of the Nashi Ethnic Group in Yunnan: Between China and Tibet 雲南ナシ族政権の歴史: 中華 とチベットの狭間で (Tokyo: Keiyūsha, 2011).

ZHAO Min is Professor and Dean at the Faculty of Arts, Dali University in Yunnan, China. He has conducted extensive fieldwork in the Dali area, and he has published journal articles in Chinese on the history of western Yunnan from the perspective of historical anthropology. His present research focuses on the historical relationship between western Yunnan and north Myanmar. 


\section{Acknowledgements}

The editors and authors gratefully acknowledge support and help from the following organisation in conducting the research published in this volume.

Hong Kong SAR University Grants Committee Areas of Excellence (Fifth Round): The Historical Anthropology of Chinese Society. 


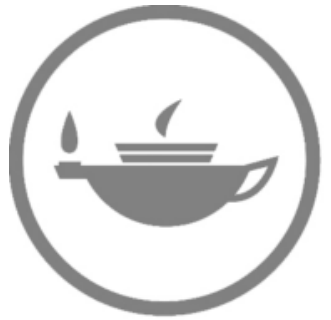

Taylor \& Francis Taylor \& Francis Group

http://taylorandfrancis.com 


\title{
Introduction
}

\section{The agency of local elites in the transformation of western Yunnan during the Ming dynasty}

\author{
Christian Daniels and Jianxiong Ma
}

This volume investigates from the perspective of historical anthropology how local elites transformed pre-1382 society in Yunnan into an imperial province during the Ming dynasty. Most scholars study the history of Southwest China within the framework of the traditional centre-local dichotomy to trace the process of assimilation and acculturation. Many interpret the expansion of the Chinese state and the spread of its institutions and Chinese culture and religions to the periphery as civilisation projects designed to ultimately transform indigenous populations into subjects of the Emperor. In this process, local elites, whether indigenous native officials (tuguan 土官) or academic degree holders, served as agents for the state, or middle men, who promoted the state's interests. ${ }^{1}$ For the past ten years, the Historical Anthropology of Chinese Society, an Areas of Excellence project funded by the Hong Kong SAR University Grants Committee and led by David Faure of the Chinese University of Hong Kong, has probed alternative approaches. Adopting a historical anthropological perspective, this volume eschews the centre-local dichotomy approach to the incorporation of indigenous peoples into Chinese administrative systems. Instead, it concentrates on investigating how the process of negotiation between diverse ethnic communities and the Ming state transformed local society. Marshalling empirical evidence to analyse local society from the bottom up, the authors demonstrate the intricate ways in which communities, both non-Han and Han, coped with incorporation and how they adapted to the profound changes wrought by Ming institutions for military and civilian control in western Yunnan between the late fourteenth and seventeenth centuries.

Emphasis on agency in the Ming transformation highlights the diverse range of transactions that occurred between local elites and the state. This emphasis reveals the versatility of local elites in adapting to ever-mutating circumstances and their dexterity in manipulating state institutions and policies to their advantage. In their investigation of the numerous ways in which local elites negotiated with the seemingly all-powerful Ming, the volume's authors demonstrate how certain ethnic groups restricted the scope of domination, thus exposing the limits of the centre's control over peripheral regions of western 


\section{Christian Daniels and Jianxiong Ma}

Yunnan. From the perspective of the centre-local dichotomy, one might say that this volume examines how local societies in western Yunnan re-made themselves to cope with the demands of the Ming state.

By selecting local society as the focus of analysis instead of the state, this volume also aims to repudiate the preconception of Yunnan as a border area isolated from civilisation at the centre by distance. In adopting the recent historical paradigm of late imperial China as a colonising power, analogous to powers on the Eurasian land mass during the early modern period, studies over the past thirty years have emphasised the role of the state and Han migrants in Chinese expansion into frontier areas. In portraying the southwest as a frontier waiting to be colonised, scholars have concentrated on such themes as state control of non-Han peoples through native officials, permanent garrisoning of soldiers, the promotion of Confucian civilisation projects, and the discourses of imperial expansion and knowledge-building for the state. ${ }^{2}$ Although providing a framework within which to compare the Chinese Empire with other empires, past studies rarely examine indigenous responses and local perspectives. This shortcoming has resulted in a one-sided account of the colonisation and civilisation processes they describe.

In contrast to such state-orientated perspectives, this volume examines how local society negotiated with Ming-imposed institutions and systems. After the Ming initiated governance in Yunnan, the newly emergent Confucian local elite, generated by the examination system, felt a compelling need to align society to match the expectations of Ming administrators. From the late fifteenth century, they advocated the reform of local customs, attempted to re-write indigenous history and even modified legends in response to the introduction of new imperial ideologies. Local elites transformed their societies through transactions with the state and regular bureaucrats. The Dali kingdom (AD 937-1253), an ethnic regime coeval with China's Song dynasty (AD 907-1279), had its own centre and periphery and possessed a distinctive political, social and religious system. The transformation of pre-Ming indigenous societies in western Yunnan progressed through the agency of local elites, who responded creatively to the Chinese version of the binary of civilised and un-civilised. The diversity of responses from local society to the extension of Ming administration in western Yunnan resulted in different degrees of subjugation to, and autonomy from, Ming rule rather than the uniform colonisation proposed by previous studies. In contrast to the colonisation model, the historical anthropological approach offers new perspectives for understanding the history of western Yunnan within the context of both mainland Southeast Asia and Southwest China.

\section{Governance prior to the conquest of $\mathbf{1 3 8 2}$}

The reason for adopting 1382 as the starting point lies in an unusual feature of local history: Yunnan remained outside the ambit of the Chinese dynastic state during the Dali kingdom period. The Mongol-Yuan founded Yunnan as a province in 1276, 137 years before the Ming established Guizhou province in 1413. However, unlike the Ming in Guizhou, the Mongol-Yuan largely relied on the 
indigenous elite, that is, the royal family and the magnate families of the Dali kingdom, to administer local societies in western Yunnan on its behalf. By restoring political power to the deposed royal family, the Mongol-Yuan preserved the socio-political-religious culture of the Dali kingdom until 1382. Therefore, the Mongol-Yuan conquest of Yunnan in 1254 and Yunnan's subsequent founding as a province in 1276 did not represent a complete rupture with the past but conversely ended up prolonging the life of certain Dali kingdomperiod institutions. It was the arrival of the Ming that triggered the transformation of the local society into an imperial province.

The protraction of the Dali kingdom's socio-political-religious culture arose out of peculiar historical circumstances. After toppling the Dali kingdom in 1254, the Mongol-Yuan restored temporal and religious authority to the last Dali King Duan Xingzhi 段興智 in 1255 to utilise his power and authority in the pacification of Yunnan and the conquest of kingdoms in mainland Southeast Asia. The Mongol-Yuan even revived the King's Sanskrit regal title maharajā (maheluocuo 摩訶羅嵯) in 1256 to facilitate his governance of local societies. This title connoted Duan Xingzhi's role as a Buddhist King, a cakravartin or universal ruler, and emphasised the Duans as a royal family reincarnated from a Buddha descended from the Tusita heaven. The Duans governed local society in Yunnan and contiguous northern mainland Southeast Asia under the new title of Duan Family General Administrator (Duan shi zongguan 段氏總管), a hereditary office that endured for twelve generations of Duan males until 1382. This arrangement benefitted the Mongol-Yuan because it enabled it to mobilise Duan-led “Cuan-Bo armies” (瞅來束軍) to eradicate local resistance and to conquer the Southern Song. After the founding of Yunnan province in 1276, the Mongol-Yuan rescinded the Duan entitlement to govern the whole of Yunnan on its behalf and confined the Duan administrative authority to western Yunnan and Mon-Khmer and proto-Tai/Tai polities situated along the transportation routes leading to the upper Ayeyarwaddy River. The Duan Family General Administrator consolidated its position between 1331 and 1381 when the Mongol-Yuan provincial authorities lost their control over Yunnan and political power fell into the hands of the two Mongol imperial princes of the blood: the Yunnan King at Dali and the Liang Prince at Kunming. This configuration of power was what preserved the socio-political-religious culture of the Dali kingdom in western Yunnan until 1382, when the Ming dismantled the Duan Family General Administrator's institutions of control. ${ }^{3}$ The downfall of the Mongol-Yuan marked the demise of its association with the Dali kingdom, and local communities faced the fresh challenge of adjusting to the new rulers.

\section{Main changes wrought by early/mid-Ming governance}

For the previously mentioned reasons, the Ming conquest of Yunnan in 1382 heralded the advent of a new political, religious and ideological order in Yunnan. Central government institutions and Confucian ideology only began to penetrate local society after this momentous event. Broadly speaking, the 
transition from the Dali kingdom/Mongol-Yuan to Ming rule initiated three significant changes that resulted in the reconstruction of local society in western Yunnan, the major theme of this volume. First, rank and birthright no longer guaranteed access to official appointments as they had in Dali kingdom and Mongol-Yuan times. To gain bureaucratic appointments, males now had to compete in empire-wide examinations. The examination system generated a new Confucian elite, who replaced pre-Ming magnate families, such as the Duan 段, Gao 高 and Dong 董, as leaders of local society by the late fifteenth century. Second, the promotion of state-sanctioned religion resulted in a decline in pre1382 Buddhism. As a result of the central government's tight regulation of Buddhism through Prefectural Buddhist Registries (senggang si 僧綱司), preMing magnate families lost their role as sponsors of the faith, contributing to their demise. Third, the emergent Confucian elite began to use moral instruction to re-fashion local culture and religion to conform better to Sinitic habits and Ming socio-political structures. Members of the new local elite included renowned official scholars, such as Yang Shiyun 楊士雲 (1477-1554) and Li Yuanyang 李元陽 (1497-1580), who strove to make Ming institutions and systems more intelligible to local communities by re-interpreting local legends and history from the Dali kingdom period and earlier. The exiled Sichuanese scholar-official Yang Shen 楊慎 used two texts written in Bowen 整文 (Bai language written in Chinese characters) as sources when compiling his Dian Zaiji 滇載記 (An Unofficial History of Yunnan). Non-Chinese-language texts that still existed enabled the local elite to re-write local history and legends in Sinitic script during the sixteenth century. ${ }^{4}$ Such endeavours undoubtedly involved substantial re-interpretation.

Jianxiong Ma describes the processes initiated by this agenda for reforming ideology and beliefs in local society as social reconstruction. He argues that the new Confucian elite used the lijia 里甲 system of social control and tax collection to re-organise village communities into a form more beneficial to the Ming state. The ability to penalise non-conformist communities through the lijia system enabled the reform of an assortment of local customs and habits. ${ }^{5}$ The Confucian elite orchestrated the reconstruction of local society in response to the new infrastructure of state administration. ${ }^{6}$

Several chapters in this volume empirically demonstrate the role played by elites in the process of social transformation. The elite included local power holders, such as indigenous native officials, and even Han military officers in addition to scholar-officials, many of whom hailed from ethnic families. In his chapter, Zhao Min examines the case of the elite in Yunlong county voluntarily forging new identities under the Ming. Zhao traces the transformation of the local protective deity of Yunlong from the founder of the Dali kingdom into a new god Wang Ji 王焂 (1378-1460), a deification of the celebrated Ming Minister of War who led military campaigns in Yunnan during the wars with Mäng ${ }^{2}$ Maaw $^{2}$. By abandoning the Dali kingdom god and adopting a prominent Ming dynasty military man as their protective deity in its place, the local elite forged fresh bonds with the new dynasty while shedding its former associations 
with the Dali kingdom. The process of appropriation constituted a meaningmaking discourse between the Yunlong elite and the Ming state, indicating the extent of transformation.

\section{Lowland/upland dichotomy in western Yunnan}

The history of Yunnan and northern mainland Southeast Asia has unfolded within the topographical and ecological framework of the lowland/upland dichotomy. ${ }^{7}$ From early times, economic and political centres formed within valley basins separated from one another by mountain ranges. Despite their seeming isolation, the basins served as transportation hubs in networks that linked lowland communities with the outside world. Transportation routes crisscrossed Yunnan, interconnecting the basins with other provinces as well as with distant Southeast Asia and Tibet. Overland thoroughfares interconnected with water transport along the Yangtze and the Ayeyarwaddy (Irrawaddy) Rivers, further facilitating trade and even serving as conduits for the flow of religious and philosophical ideas to Yunnan. For local communities in pre-1382 times, the basins constituted socio-political-religious centres, roles they continued to play during the Ming and Qing periods. Therefore, the basins in Yunnan were dynamic places, sites that affected the history of the uplands as well as the lowlands. ${ }^{8}$

The geopolitical importance of the basins made it imperative for all dynasties, whether indigenous (such as the Nanzhao and Dali kingdoms) or exogenous (such as the Mongol-Yuan, Ming and Qing), to establish power bases on the lowlands to support the institutions necessary for governing Yunnan. However, the nature of the terrain complicated the governance of upland communities by the state. In many cases, the Ming only administered upland communities through the medium of native officials, who dispatched their own subordinates to superintend on their behalf. Under this system of indirect administration, the measure of control over upland communities varied greatly according to the political authority of the native official and his representatives. The protection afforded by the precipitous terrain enabled certain upland settlements to retain autonomy from the Ming state following the conquest of 1382. For instance, communities associated with Iron Chain Gorge in western Yunnan, studied by Christian Daniels in this volume, remained autonomous from the Ming state until their elimination in 1574. The emergence in these communities of an alliance of kings with a nascent bureaucracy poses an important challenge to James Scott's wellknown hypothesis that upland peoples evaded hierarchical ordering. ${ }^{9}$ The evidence from Ming sources indicates that this alliance attempted to create a polity/ polities to retain autonomy from the Ming. For nearly 200 years, these uplands were not directly governed by regular bureaucrats or indirectly governed by native officials. Thus, complete control of the lowlands did not automatically translate into jurisdiction over the surrounding uplands. Domination of basins generally preceded that of the uplands because the lowlands served as the centres of local power, supported relatively large populations, and afforded control 
over vital transportation routes. Therefore, the history of local communities in Yunnan unfolded against an intricate backdrop of lowlands, uplands and transportation routes.

\section{Civilising projects}

Previous historians of Southwest China writing in English have emphasised the role of state-sponsored civilising projects. Chinese emperors drew sharp distinctions between civilised Chinese and non-civilised barbarians. To facilitate administration and promote unification, the state adopted a series of measures aimed at acculturating non-Han populations. With the expansion of direct and indirect administration of non-Han peoples in the southwest, the Ming and Qing states promoted the sinicisation of non-Han elites through education. The settlement of large numbers of Han soldiers during the Ming and later economic migrants exposed ethnic people to Han culture and ways of life. Certain historians regard these measures as part of a larger process of state-orchestrated colonisation of the southwest. ${ }^{10}$ They identity what Steven Harrell has termed the "Confucian civilising mission" as a moral justification for the state expanding into non-Han areas. ${ }^{11}$ State-sponsored civilisation projects may have inadvertently inspired Ming local elites at Dali to reconstruct the identity of the Bai 白 people, the main ethnic group of the Dali kingdom. Hou Chong 侯冲 argues that Bai ethnic consciousness and the legends supporting it emerged as a response to the Ming conquest. ${ }^{12}$ Expanding on Hou Chong's research, Megan Bryson explains the creation of the Bai as an ethnic group by local elites on the Dali plain within the framework of the Chinese-barbarian binary. She maintains that finding themselves now categorised as barbarians in the Ming civilising project, local elites "began to represent themselves as 'Bai' in a way that seems to fit into ethnic discourse". ${ }^{13}$ Local elites created the Bai ethnicity out of the compelling need to distinguish themselves as an ethnic group separate from the newly arrived Han soldiers resettled in western Yunnan by the state. The new Confucian elite emerged as the successors to magnate families of the Dali kingdom period and re-arranged previous legends to sharpen the distinction between indigenous and Han settler communities. In this scenario, the local elite acted as agents of cultural transformation, re-creating ethnic identity in the course of sustained contact with the Han soldier settlers who threatened their traditional cultural and religious institutions.

\section{Role of Buddhism in the pre-1382 period}

Buddhism featured as a prominent universalising discourse throughout the societies in western Yunnan in the pre-1382 period. It served as an ideology with which the Dali kingdom could integrate the diverse ethnic groups into its political organisation. With Duan monarchs standing at the apex of society as Buddharājas (Ch: 佛王), or Buddha-kings, supported by the Gao and other magnate families, Buddhism shaped the political organisation of the kingdom. 
Although no scholars question the "civilising" force of Buddhism, consensus is lacking regarding the transmission routes of Buddhism to Yunnan and the origin of its religious culture during the Dali kingdom period. Hou Chong 侯冲 proposes the most extreme view by claiming China as the sole source of Buddhist influence in Yunnan. Hou bases his argument on the fact that all extant Dali kingdom Buddhist scriptures derive from China. According to him, even the unique texts that only survive in Yunnan originally existed in China but were subsequently lost. Hou also denies the possibility of Tantric Buddhism deriving from anywhere but China by rejecting the possibility of direct transmission from India, Tibet or Southeast Asia on the grounds of insufficient written evidence. Based on his assumption of a single origin in China, Hou plays down the uniqueness of Dali Buddhism. ${ }^{14}$ In contrast, Megan Bryson has empirically demonstrated certain distinctive elements in the politico-religious system of Dali kingdom Buddhism and notes a tension between universality and localising forces in the creation of local deities. ${ }^{15}$ Bryson notes the non-Chinese origins of two gods in the pantheon of the Dharma Guardians protecting the Dali kingdom. These gods, Fude Longnü 福德龍女/Baijie Shengfei 白姐聖妃 and Mahākāla (Ch: Dahei tianshen 大黑天神), were both of regional origin and of regional significance. Bryson shows that Fude Longnü/Baijie Shengfei was a hybrid figure that combined Indian and Chinese elements as well as local and translocal elements. Buddhists in Southeast Asia, India, Tibet, Central Asia, Tang China and Yunnan commonly used figures of Mahākāla. Bryson argues that court Buddhists in the Dali kingdom created their own ritual texts centred on their own tutelary deities derived from Chinese sources, which projected the "consistent image of Dali Kingdom Buddhism as Indian". ${ }^{16}$

The historian of Buddhist art Ku Chengmei 古正美 has created a novel perspective on the politico-religious organisation of the Dali kingdom in her recent re-interpretation of the Zhang Shengwen Fanhua Juan 張勝溫梵畫卷 (The Long Scroll By Zhang Shengwen) of 1180, a principal source for this kingdom. Drawing on a variety of sutras in the Chinese Tripitaka, she notes the common practice of Buddharājas (Ch: 佛王) founding and ruling Mahayana kingdoms in India, Southeast Asia and even China until the twelfth century. Ku identifies two types of Buddhist concept of royalty (fojiao jianguo xinyang 佛教建國信仰) employed by Dali kings. The first type belonged to the esoteric Avalokiteśvara Buddhist conception of royalty (mijiao Guanyin fowang jianguo xinyang 密教觀 音佛王建國信仰), while the second type constituted a version of caitya worship (zhiti xinyang 支提信仰), which revered the Vairocana Buddha (Piluzhena Fo 毘盧遮那佛) as a Buddharāja who was at once both a Buddha and a King ( ji shi fo you shi wang 既是佛又是 王). The role of the Vairocana Buddha as a founder of Buddhist kingdoms derives from the Gandavyūha (Ch: Rufajie Pin 入法界品) in the section of the Flower Garland Sutra (Avatamsaka Sütra, Ch: Huayan Jing 華嚴經). According to Ku Chengmei, Duan Zhixing 段智興, the reigning Emperor from 1172 to 1200, terminated Avalokiteśvara worship as practised by his father Duan Zhengxing 段正興, alternatively known as Duan Yizhang 段易長 (1148-1172). Instead, Duan Zhixing shifted to Buddharāja 
worship and reigned as the Vairocana Buddha, enlisting monks to promote reverence for the Vairocana Buddha throughout the kingdom. $\mathrm{Ku}$ argues that his son Duan Zhilian 段智廉 (reigned 1201-1205) continued this type of Buddharāja worship. ${ }^{17}$ Although no evidence exists for Buddharāja worship after 1205, we can hypothesise that the concept of Duan Kings governing as Buddharājas underpinned their authority to rule local society until the fall of the Mongol-Yuan in 1382.

\section{Establishment of new civilian and military institutions}

The authors of this volume share a common understanding of Ming institutions, particularly the new military and civilian institutions for control and administration. These institutions profoundly changed the socio-political-religious culture of western Yunnan during the fifteenth and sixteenth centuries. As background to the theme of transformation, we briefly elucidate the main institutional changes.

In addition to establishing military and civilian institutions, the state also promoted Ming Confucian ideology through schools founded in the jurisdictions of both regular bureaucrats and native officials. Many lowland communities were transformed in the process of adapting to these institutions. However, certain upland communities rejected them outright, steadfastly refusing to comply. In this volume, while Huang Caiwen emphasises the contributions of military institutions to economic growth in Beisheng sub-prefecture, Yamada Noriyuki demonstrates how the Native Official of Lijiang manipulated the Ming court's trust in his loyalty and its dependence on his army to prevent Tibetan intrusions to expand his territory into the Kham region of eastern Tibet. Upland communities in the internal frontier centred at Iron Chain Gorge chose to maintain autonomy from the Ming for 200 years (see the chapter by Daniels). Local communities in western Yunnan responded to Ming institutions in diverse ways depending on the level of exposure and their respective circumstances.

\section{Administrative status of population}

The establishment of governance entailed the registration of the populace. As elsewhere in Southwest China, broadly speaking, the Ming state divided the population of western Yunnan into three categories: civilian tax-paying households (minhu 民户), military households (junhu 軍戶) and unregistered, or ethnic, people (yiren 夷人; literally, “barbarians”). Regular bureaucrats directly administered civilian households, thereby facilitating social control and the collection of taxes through empire-wide systems, such as the lijia and the baojia. The military household category consisted of Han soldiers settled in Yunnan by the state after 1382 .

Native officials (tuguan 土官) constituted the backbone of dynastic administration in Yunnan from the Mongol-Yuan onwards. However, this practice of governing indigenous communities through intermediary native officials prevented the registration of people within their jurisdictions as civilian tax-paying 
households. The Mongol-Yuan governed western Yunnan through the agency of a single intermediary native official: the Duan Family General Administrator. The Ming replaced the Duan with a system of direct and indirect rule, appointing regular bureaucrats (liuguan 流官) to administer prefectures, sub-prefectures and counties directly, and assigned numerous hereditary native officials to govern indigenous peoples indirectly. This approach transformed Yunnan into a patchwork of directly and indirectly ruled areas. In effect, native officials were local leaders appointed as ranked imperial officials, each individually responsible to the Ming state. The Ming distributed the political power originally wielded by the Duan family amongst numerous local leaders scattered over western Yunnan. The native officials benefitted because titles of appointment from the Ming state bolstered their authority to govern their jurisdictions.

By permitting native officials to govern their own ethnic peoples in accordance with customary law and regulations, the Ming found it difficult to register populations under their jurisdiction. This difficulty hindered the organisation of people under native official jurisdiction into lijia and baojia. Nevertheless, historical sources reveal that certain native officials in lowland basins did register their populations (bian hukou 編戶口), referring to them as ethnic households (yihu 夷戶). ${ }^{18}$ The state's inability to directly govern all ethnic peoples compelled regular bureaucrats to partially administer them through the medium of native officials after gaitu guiliu 改土 歸流 in certain cases. Gaitu guiliu refers to the abolition of the appointment of native officials and their replacement by regular bureaucrats. Circumstances often required regular bureaucrats to jointly administer together with the "abolished" native officials. The state retained the services of "abolished" native officials when large differences in language and culture rendered it impossible for regular bureaucrats to govern ethnic societies without the backing of local leaders. By retention, the state continued to acknowledge the authority and the influence of native officials over certain sections of the ethnic population under the jurisdiction of the regular bureaucrats. Joint administration by regular bureaucrats and native officials, an arrangement known as tuliu jianzhi 土流兼治, has been documented for Menghua prefecture in western Yunnan. ${ }^{19}$ The state clearly defined and regulated the native official system. However, the realities of political power in local society forced the state to improvise when trying to convert to direct administration. This process created multiple layers of administration under the umbrella of a regular bureaucrat.

\section{Establishment of Guards and Battalions and the Mäng ${ }^{2} \mathrm{Maaw}^{2}$ polity}

Zhu Yuanzhang, the founding Emperor of the Ming, established Guards and Battalions (weisuo 衛所) across the country for the maintenance of social stability. In border areas threatened by external regimes, such as western Yunnan, the Guards and Battalions played a particularly important role in defence. The soldiers settled in the Guards and Battalions comprised the backbone of the military during early Ming. The state established Guards and 
Battalions in Yunnan from $1388^{20}$ and positioned them within the jurisdictions of both regular bureaucrats and native officials. The state controlled the military through three levels of command emanating from the capital and extending down to the local level. Situated at the bottom of the command chain, the Guards reported to the Yunnan Regional Military Commission (du zhihui shi si 都指揮使司), which in turn took orders from the Five Military Commissions (wu jun dudu fu 五軍都督府) at the capital, the highest military authority in the empire. Grain depots at the Guards served as vital centres for providing soldiers and their families with food supplies.

Geopolitics affected the siting of Guards and Battalions. The early Ming faced a constant threat from what they viewed as the war-mongering Tai polity of Mäng ${ }^{2} \mathrm{Maaw}^{2}$ (Ch: Luchuan 麓川) at the southwestern tip of the province. The emergency lasted for sixty-two years until 1449, when Ming forces finally toppled the polity's stronghold in present-day Dehong zhou 德宏州. From the perspective of the Ming state, western Yunnan constituted a strategically important border area adjoining Myanmar, Laos and Vietnam to the south and Tibet to the northwest. To mobilise soldiers swiftly and provide logistical support for military campaigns against intrusions from outside, the Ming established Guards and Battalions along communication routes across western Yunnan.

The Guards and Battalions in areas around Dali prefecture prevented unrest at the former centre of Dali kingdom political power in addition to defending the lowlands against raiding by upland ethnic groups from the internal frontier known as Iron Chain Gorge. The Ming founded Guards and Battalions at Yongchang and Tengchong to thwart intrusions by the Mäng ${ }^{2} \mathrm{Maaw}^{2}$ polity and established the Lancang Guard to maintain security along the communication routes leading to Tibet and Sichuan. Permanent stationing of the military at strategic positions on thoroughfares stabilised the surrounding areas and provided protection for officials, soldiers and merchants. In his chapter, Zhao Min notes the importance of grain delivery for feeding the Guards, highlighting the role these routes played in the transportation of resources necessary for the maintenance of Ming control in western Yunnan.

The Ming avoided imperial overreach by refraining from establishing Guards and Battalions within northern mainland Southeast Asia. The Mongol-Yuan administered as far south as Northern Thailand and even stationed troops at Tagaung on the upper Ayeyarwaddy River for approximately eighteen years between 1285 and $1303 .{ }^{21}$ By c.1360-1370, the configuration of political power on the southwest periphery of Mongol-Yuan rule had changed drastically. The newly emergent Tai polity of Mäng ${ }^{2} \mathrm{Maaw}^{2}$ now not only blocked Ming expansion into Southeast Asia but also forcefully occupied parts of southern Yunnan. The Ming responded by issuing thirteen new native official titles to the rulers of small Tai polities in an effort to dissipate Tai political power between 1400 and 1439. By conferring native official titles on these Tai rulers, the Ming aimed to weaken the bonds of allegiance between the title recipients and their former overlords in Mäng ${ }^{2} \mathrm{Maaw}^{2}{ }^{22}$ The Ming required a long, difficult eleven years of 
mobilising troops and intensive campaigning between 1438 and 1449 to overcome this polity. ${ }^{23}$ After eliminating this adversary, the Ming adhered to its policy of appointing Tai rulers as native officials and refrained from establishing Guards and Battalions in contiguous parts of Southeast Asia, locating them within the confines of Yunnan province.

The Guards and Battalions were founded on the basic principle of selfsufficiency. The state permanently settled soldiers and their families at local Guards and established military farming colonies (juntun 軍屯) to make them self-sufficient in food. The state provided oxen, tools and seeds. ${ }^{24}$ Zhu Yuanzhang approved the establishment of military colonies in Yunnan as early as 1386 (Hongwu 19). ${ }^{25}$ The court assigned one farming colony to every Guard and set the ratio of soldiers cultivating military colony land (tunzhong 屯種) to those training and guarding (caoshou 操守) at 7:3. According to the 1510 Zhengde Yunnan Gazetteer 正德雲南志, the allocation of 30 per cent to guarding duties was 10 per cent higher than in China proper, where the ratio was 8:2. ${ }^{26}$ Presumably, Yunnan required a higher proportion of combat soldiers to pacify resistance until the 1390s and for defence against $\mathrm{Mäng}^{2} \mathrm{Maaw}^{2}$, which remained a deadly menace until c.1450. The allocation of 10 per cent more soldiers to guarding duties reduced the percentage available for clearing virgin land for cultivation, thereby escalating the demand for grain transported from outside Yunnan.

The Guards and Battalions exerted long-lasting influence on local history in a number of concrete ways. First, they introduced a sizeable Han population into the ethnoscape of Yunnan for the first time. The influx of Han soldiers placed pressure on arable land resources, and the inability to grow sufficient grain for their sustenance caused local food shortages. Zhu Yuanzhang originally followed the Mongol-Yuan practice of conscripting large numbers of soldiers from civilian households, many of whom had served in the armies of the MongolYuan and warlords. ${ }^{27}$ From 1383 until the early Yongle reign period, the Ming court mass-conscripted civilians. ${ }^{28}$ Soldiers assigned to Guards and Battalions in Yunnan may have come from their ranks. The Ming mobilised 1.56 million soldiers for the pacification of Yunnan during the period 1381-1391 (Hongwu 14Hongwu 24). Sources reveal that the number of soldiers stationed in Yunnan ranged from 27,000 in 1381 to 35,000 in $1382,57,000$ in 1383 , and 35,000 in $1390 .{ }^{29}$ According to Fang Guoyu, the quota required to man the Battalions established in Yunnan (1,120 men per Battalion) over the entire Ming period amounted to 146,720 soldiers. It is unknown if these quotas were ever filled. However, a breakdown over time gives 129,920 for the Hongwu period, an additional 12,320 added after the Zhengtong period, and a further 4,480 added after the Wanli period. ${ }^{30}$ These figures exclude family members and do not represent incremental increases over generations. More specifically, they do not take into account that the non-serving sons of military personnel had their own families and were transformed into civilian residents. James Lee estimates that the population of Yunnan may have reached four million by the early sixteenth century. ${ }^{31}$ Although the exact figures are unknown, soldiers constituted the bulk of the first 
large-scale Han migrants during the early Ming. The structure of the Guards and Battalions created Han communities moulded according to the needs of the military.

The second influence was the spin-off effect of Guards and Battalions on local society. As demonstrated by Huang Caiwen in this volume, the Lancang Guard became a catalyst for change in local communities, occasionally influencing communities under native official jurisdiction. The postal relay stations, forts, outposts and markets established by the Lancang Guard promoted communication and trade and even facilitated the growth of lowland/upland networks. Therefore, the guard and battalion system created an infrastructure for implanting Ming governance and socio-economic norms into local society. In addition, the decline of state institutions supporting the military inadvertently promoted transformation. The Ming commissioned merchants to deliver grain to Guards whose military farming colonies could not produce sufficient rice to feed the soldiers. The state incentivised merchants to deliver grain from outside Yunnan to guard granaries in return for lucrative licences to sell government salt. Under this arrangement, known as the salt-barter system (kaizhong $f a$ 開中法), alternatively translated as the border delivery system, ${ }^{32}$ regular bureaucrats issued merchants with salt licences (yanyin 鹽引) for conversion into specified quantities of salt in exchange for delivering grain. ${ }^{33}$ The exchange rate of grain-to-salt licences fluctuated depending on the distance travelled and licence type. ${ }^{34}$ The high cost associated with the transportation of grain to Yunnan and the increase in grain prices could deter merchants from delivering grain and resulted in the collapse of the salt-barter system. In his chapter, Zhang Min traces how such a collapse caused profound changes in western Yunnan during the fifteenth century. The breakdown forced the state to rely on local magnates and in certain cases on local military officials for grain supplies. State provision of incentives for local magnates to sell their stockpiled grain ended up creating new wealth, which in turn fostered the rise of new local merchants and even caused shifts in the ethnic composition of the local population. Zhang Min's case study clearly shows how the breakdown of a Ming state institution contributed to the transformation of local society in Yunlong county during the late fifteenth century.

Third was the impact of the decline of the Guards and Battalions after the mid-1430s due to widespread desertion. This development was an empire-wide phenomenon, and in Yunnan, it coincided with the Mäng ${ }^{2} \mathrm{Maaw}^{2}$ emergency. In the aftermath of the Tumu Crisis 土木之變 of 1449, the Ming introduced measures to rectify the trend. However, the court only attempted to fully restore the Guards and Battalions to their original condition during the Chenghua reign (1465-1487). Although all efforts at reconstruction ended in failure, the Ming did not abolish this institution. Therefore, the military household registration system survived until the end of the dynasty. In his chapter, Huang Caiwen argues that the expansion of market-exchange networks, the extension of communication lines and the ascent of local elites loyal to the Ming court gradually weakened the position of the Guards and the Battalions as brokers between native officials and the Ming state. Huang also notes that the decline of the 
Lancang Guard from the mid-Ming onwards enhanced the gradual conversion of military households into local civilian households. This series of changes resulted in the local native official strengthening his political authority over these military institutions. It is well known that the decline of the Guards and Battalions compelled the Ming to depend on native officials for troops in emergencies. The case of the campaign against Iron Chain Gorge demonstrates the extent to which the Ming relied on the military forces of native officials for large offensives against bandits after the mid-sixteenth century. All of the 6,400 soldiers mobilised to fight at the front line in this campaign came from native official jurisdictions in today's Chuxiong, Lijiang and Dali prefectures. Troops from the Guards were stationed outside the battle zone.

\section{Ming transition and ethnic groups}

In a union of opposites, governance in western Yunnan encompassed lowlands under Ming jurisdiction and autonomous uplands from 1382 until 1574. Lowland/upland relations were not always harmonious. Communities associated with Iron Chain Gorge disturbed lowland life for nearly 200 years. Although constrained by the limited reach of governance, Ming institutions created a new socio-political-religious culture in the lowlands. As previously mentioned, moral instruction by local elites also contributed to the transformation. Changes wrought by Ming institutions on lowland ethnic groups pose a challenge to the applicability of concepts such as acculturation and assimilation. Past studies have emphasised the sinicisation of indigenous peoples as a main component of state expansion into Southwest China from early times. In the centre-local dichotomy scenario, administration by regular bureaucrats and native officials resulted in shifts of ethnic identity from non-Han to Han over time. By linking ethnicity to household registration categories introduced by the Ming, Jianxiong $\mathrm{Ma}$ in this volume suggests an alternative way of understanding the impact of state expansion on ethnic identity.

Ma traces the institutional origin of social identity in three valley basins in Eryuan county to state-imposed social categories and shows how the household registration system shaped ethnic categories. The Ming household registration categories and the application of the lijia system for the collection of taxes and social control created diverse identities in local society. After the fall of the Ming, three new ethnic identities replaced these categories: the Minjia 民家 (the Bai people), the Han and the Luoluo (the Yi). The Minjia and the Han resided in the lowlands, while the Luoluo dwelt in the uplands under the jurisdiction of native officials. These three ethnic categories emerged coevally with the appearance of new basin communities under the leadership of local elites from the late seventeenth century. According to Ma, these new communities forged social alliances that extended beyond the boundaries of family, kinship, and li and jia units. Because ethnic categories were shaped by household registration, Ma concludes that this process should be understood as a transformation of Ming local identities into new categories of ethnic identity created under the changed 
socio-politico-economic conditions of the late seventeenth/eighteenth century. This process constituted a re-definition of non-Han ethnic groups and did not result in "sinicisation", or a mass shift in ethnicity from non-Han to Han. People who had identified themselves as Bai during the Ming period now became known as Minjia. The localisation of military households as civilians occasionally contributed to an overlapping of Minjia and Han. There was continuity and fluidity in ethnicity as categories mutated. However, in the end, the non-Han/ Han distinction remained in the local multilingual environment.

The argument presented by Jianxiong Ma draws attention to the fluidity of ethnic identity, an issue studied by Edmund Leach in his classic ethnography of the Kachin and Shan (Tai) in northern Myanmar. Leach demonstrated how shifts in social structure could transform Kachin societies into Shan societies within one generation. This rapid transformation was possible because Kachin societies originally oscillated between two opposing social systems. The first was an egalitarian system known as gumlao. The second was a hierarchical, aristocratic system termed gumsa, which was presided over by a hereditary leader. The gumsa system strongly resembled the societies of the Shan and other Tai-speaking groups who dwelt in valley basins. ${ }^{35}$ In contrast to Leach, Ma understands ethnicity in Ming/Qing western Yunnan as being reconstructed within the context of factors such as long-term interaction between communities within the region, administrative change and the role of overland trading networks that extended to the Ayeyarwaddy River region in northern Burma. Ma emphasises that the reconstruction of Minjia identity arose in close connection with shifts in state institutions and under different historical and ecological conditions than those obtaining in the Kachin and Shan communities studied by Leach.

Ma's research reveals that irrespective of their ethnicity, lowland communities in Eryuan county shared the similar characteristic of establishing common property for the purpose of generating income to support religious practices from the late seventeenth century. All community members participated in these religious activities. The new social environment of common property held under the name of village temples and managed by the gentry and village leaders included intermarriage between families with diverse histories of household registration and even marital unions between different ethnic groups. However, despite extremely strong cohesiveness between village communities during the turmoil of the Islamic rebellion led by Du Wenxiu between 1856 and 1873, local people continued to draw sharp distinctions between the Minjia and the Han.

One salient feature of community organisation in Yunnan was the absence of management according to patrilineal lineages, or kinship principles. David Faure traces the origins of the lineage as an institution to the Ming period. The popularisation of Confucian ancestor worship amongst the wider civilian population spread with the rise of the lineage. As Faure elaborates, ancestor worship was originally only practised by elites and nobility, including state officials. It was not until after the 1530 s that this practice become normalised in the population at large. This normalisation was due in large measure to changes in tax collection and registration policy. Instead of registering individuals for tax purposes, 
the Ming state began to register land. Land itself could be owned collectively under many names, resulting in the emergence of lineages as "corporations" in the southeast littoral of China. ${ }^{36}$ The circumstances in western Yunnan differed. First, the lineage as an institution had not yet been embraced by the civilian population in China proper when Ming military personnel were resettled in Yunnan. Therefore, lineage-building did not spread to Yunnan hand-in-hand with Han migration during the late fourteenth and fifteenth century. Second, as demonstrated by Jianxiong Ma in his study on Eryuan, when the holding of common property emerged in seventeenth-century communities, it was the village temple, not Minjia or Han family lineages, that took possession. Although gentry and village leaders managed the common property, they did so as individuals, not as representatives of lineages or larger kinship groups.

\section{Notes}

1 David Faure and Ho Ts'ui-P'ing, Eds. (2013), pp. xi-xii.

2 For instance, see Peter Perdue (2005); James Millward (1998); Laura Hostetler (2001); C. Patterson Giersch (2006); Richard Von Glahn, (1987); and Steven Harrell, ed. (1994).

3 Christian Daniels (2018), pp. 69-111.

4 Fang Guoyu (1984), Vol. 1, p. 372.

5 Regarding social reconstruction, see Ma Jianxiong (2014). For an account of the lijia 里甲 system and how it functioned as more than a mere tax-collection unit, see Tsurumi Naohiro (1984).

6 See Ma Jianxiong (2014) and Ma Jianxiong (2017).

7 James C. Scott (2009), pp. 1-63.

8 Ken Kirigaya argues that access to trade flows both from maritime trade via the Ayeyarwaddy River and from the overland trade routes through Yunnan from China brought new wealth and military technologies that caused the reconfiguration of political power in western mainland Southeast Asia. Although these factors initially resulted in the political expansion of the basin-based Tai polities during the fifteenth century, these polities were ultimately subordinated to Burman dynasties located closer to the coast that had access to maritime trade and European firearms during the sixteenth century; see Ken Kirigaya (2018). For a study on the complex trading networks linking the lowland/upland of nineteenth- and early twentieth-century Yunnan, Sichuan, the Kham region of Tibet and Southeast Asia, see C. Patterson Giersch (2010).

9 For a full account of the hypothesis, see James C. Scott (2009).

10 For instance, regarding the Southern Lu in Sichuan during the Song, see Richard von Glahn (1987), and for Guizhou, John E. Herman (2007) and Laura Hostetler (2001).

11 Steven Harrell, "Introduction: Civilising Projects and the Reaction to Them", in Steven Harrell (1994), pp. 4-7.

12 Hou Chong (2002), pp. 96-102. In this study, Hou notes evidence for the emergence of the Bai identity in the Mongol-Yuan period by drawing attention to the legends concerning Long Asoka, Shayi 沙壹 and the Bai kingdom.

13 Megan Bryson (2017), p. 88.

14 Hou Chong (2002) and Hou Chong (2006).

15 Megan Bryson (2017), p. 9, pp. 55-57.

16 Megan Bryson (2017), pp. 55-57, pp. 80-82.

17 Ku Chengmei (2018), pp. 76-90. Ku Chengmei's principal evidence for Duan Zhixing reigning as the Vairocana Buddha comes from paintings 63-67, 84 and 104 in the 


\section{Christian Daniels and Jianxiong $M a$}

Zhang Shengwen Fanhua Juan. Titled "a painting of investment as emperor and king (feng wei huangdi piaoxin tu 封為皇帝驃信圖)”, paintings 63-67 depict Duan Zhixing (the Lizhen Emperor 利貞皇帝) as a Buddharāja in the form of the Vairocana Buddha seated in the middle with two disciples of the Buddha (Kassapa and Ananda) standing beside him, flanked by two Avalokiteśvaras 觀音, one on each side. The Avalokiteśvara on the left is further flanked by the Puxian Bodhisattva 普賢菩薩 riding a white elephant and that on the right is accompanied by the Wenshu Bodhisattva 文殊 菩薩 seated on a lion. Because the Vairocana Buddha as a Buddharāja in a set of seven images appears at Dazu in Sichuan, Ku concludes that Duan Zhixing borrowed the Vairocana Buddha from monks associated with Dazu, thus indicating that he introduced it from the Southern Song. Ku also notes that paintings 63-67 the Zhang Shengwen Fanhua Juan actually depict the Vairocana Buddha as a Buddharāja in a set of eleven images. The four additional images include two god-kings (shenwang 神王) and two vajra-guardians (jingang lishi 金剛力士). See Ku Chengmei (2018), pp. 76-78.

18 For instance, the first Native Official of Dengchuan Zhou 鄧川州土官知州 (in today's Eryuan county), A Zhe 阿這 (appointed c.1383), registered his population; see the tomb inscription Dengchuan Zhou Tuguan Zhizhou Ashi Wushi Mubiao 鄧川 州土官知州阿氏五世墓表 of 1508 (Zhengde 3) written by Yang Nanjin 楊南金, a native of Dengchuan Zhou, in Yang Shiyu and Zhang Shufang, Eds. (1993), p. 71.

19 Tang Li (2016), pp. 31-58.

20 The Veritable Records documents the establishment of Left, Right and Front Guards in Yunnan prefecture 置雲南左, 右前三衛中, 左千戶所 on 3 January 1388 (Hongwu 20/eleventh month gengzi day); see Taizu Shilu, p. 2800.

21 Christian Daniels (2018), pp. 217-222.

22 Christian Daniels (2006), pp. 30-33.

23 Liew Foon Ming (1996), pp. 162-203.

24 Wang Yuquan (1965), pp. 114-115.

25 According to the Veritable Records, Mu Ying 沐英 submitted a memorial requesting permission to establish military farming colonies in Yunnan on 30 September 1386 (Hongwu 19/ninth month gengshen day):

Yunnan has exceptionally broad expanses of land, much of which lies uncultivated. We should declare the establishment of military farming colonies (tun 屯) and order the soldiers to open up and cultivate land in order to store reserves of grain 雲南土地甚廣而荒無居多, 宜宣置屯, 令軍士開耕以備儲偫。.

See Taizu Shilu, pp. 2709-2710.

26 Peng Gang and Zhou Jifeng, Zhengde Yunnan Zhi, 2:10a-10b, pp. 123-124. The original reads: “又内地各衛俱二分操守, 八屯種, 雲南三分操守, 七分屯種。”.

27 Li Xinfeng (2016), pp. 241-244, and Yu Zhijia (1987), pp. 4-5.

28 Li Xinfeng (2016), pp. 246-248.

29 Okuyama Norio (2003), p. 204, p. 217.

30 Fang Guoyu (2003), p. 162.

31 Li Zhongqing (2012), pp. 132-136.

32 Foon Ming Liew translates kaizhong $f a$ as "salt-barter system", while Timothy Brook translates it as "border delivery system"; see Liew Foon Ming (1984), p. 15, and Timothy Brook (1998), p. 108.

33 One standard yin 引 equalled 400 jin of salt in the Ming. However, during the Hongwu reign, smaller yin of 200 jin were also used. The equivalences of yin varied across regions and time periods; see Ray Huang (1974), p. 193.

34 Conversion rates varied greatly from a high of five dan to a low of one dou and three sheng for one licence; see Liew Foon Ming (1984), pp. 19-22.

35 E. R. Leach (1954).

36 David Faure (2007). 


\section{Bibliography}

Brook, Timothy. The Confusion of Pleasure: Commerce and Culture in Ming China. Berkeley, Los Angeles, London: University of California Press, 1998.

Bryson, Megan. Goddess on the Frontier: Religion, Ethnicity and Gender in Southwest China. Stanford: Stanford University Press, 2017.

Daniels, Christian. "Historical Memories of a Chinese Adventurer in a Tay Chronicle: Usurpation of the Throne of a Tay Polity in Yunnan, 1573-1584". International Journal of Asian Studies, Vol. 3 (2006), pp. 21-48.

Daniels, Christian. "The Mongol-Yuan in Yunnan and ProtoTai/Tai Polities during the 13th-14th Centuries". Journal of the Siam Society, Vol. 106 (2018), pp. 201-243.

Fang Guoyu 方國瑜. Yunnan Shiliao Mulu Gaishuo 雲南史料目錄概說. Beijing: Zhonghua Shuju, 1984. 2 volumes.

Fang Guoyu 方國瑜. “Mingdai zai Yunnan de Juntun Zhidu Yu Hanzu Yimin 明代在雲 南的軍屯制度與漢族移民 (The System Military Farming Colonies in Yunnan and Han Migrants in the Ming Period)”. In Fang Guoyu, Fang Guoyu Wenji 方國瑜文集 (The Collected Works of Fang Guoyu). Kunming: Yunnan Jiaoyu Chubanshe, 2003, Vol. 3, pp. 145-332.

Faure, David. Emperor and Ancestor: State and Lineage in South China. Stanford: Stanford University Press, 2007.

Faure, David, and Ho Ts'ui-P'ing, Eds. Chieftains into Ancestors: Imperial Expansion and Indigenous Society in Southwest China. Vancouver: UBS Press, 2013.

Giersch, C. Patterson. Asian Borderlands: The Transformation of Qing China's Yunnan Frontier. Cambridge and London: Harvard University Press, 2006.

Giersch, C. Patterson. “Across Zomia with Merchants, Monks, and Musk: Process Geographies, Trade Networks, and the Inner-East-Southeast Asian Borderlands". Journal of Global History, Vol. 5 (2010), pp. 215-239.

Harrell, Steven, Ed. Cultural Encounters on China's Ethnic Frontiers. Seattle: University of Washington Press, 1994.

Herman, John E. Amid the Clouds and Mist; China's Colonisation of Guizhou, 1200-1700. Cambridge and London: Harvard University Asia Center, 2007.

Hostetler, Laura. Qing Colonial Enterprise: Ethnography and Cartography in Early Modern China. Chicago and London: The University of Chicago Press, 2001.

Hou Chong 侯冲. Baizu Xinshi: “Bai gu tongji” yanjiu 白族心史一《白古通記》研究. Kunming: Yunnan Minzu Chubanshe, 2002.

Hou Chong 侯冲. “Dali Guo Xiejing Yanjiu 大理國寫經研究”. Minzu Xuebao, No. 4 (December 2006), pp. 11-60.

Huang, Ray. Taxation and Governmental Finance in Sixteenth-century Ming China. Cambridge: Cambridge University Press, 1974.

Kirigaya Ken. "Tay (Shan) Encroachments into the Irrawaddy Basin and the Fall of Ava: Western Mainland Southeast Asia in the "Age of Commerce'". Journal of the Siam Society, Vol. 106 (2018), pp. 245-277.

Ku Chengmei 古正美. “Zhang Shengwen Fanhua Juan” Yanjiu: Yunnan Houli Guo Duan Zhixing Shidai de Fojiao Huaxiang 《張勝溫梵畫卷》研究: 雲南后里國段智 興時代的佛教畫像 (Research on the Long Scroll By Zhang Shengwen: Buddhist Portraits at the Time of Kingship of Duan Zhixing of the Houli Kingdom in Yunnan). Beijing: Minzu Chubanshe, 2018.

Leach, E. R. Political Systems of Highland Burma: A Study of Kachin Social Structure. London: The London School of Economics and Political Science and G. Bell and Sons Ltd, 1954. 
Li Xinfeng 李新峰. Ming Qianqi Junshi Zhidu Yanjiu 明前期軍事制度研究 (Research on the Military System in the Early Ming). Beijing: Beijing Daxue Chubanshe, 2016.

Li Zhongqing 李中清 (James Lee). Zhongguo Xinan Bianjiang de Shehui Jingji: 12501850 中國西南邊疆的社會經濟: 1250-1850 (Society and the Economy in Southwest China: 1250-1850). Beijing: Renmin Chubanshe, 2012.

Liew Foon Ming (劉奮明). Tuntian Farming of the Ming Dynasty (1368-1644). Mitteilungen der Gesellschaft für Natur- and Völkerkunde Ostasiens, Band 97. Hamburg: Gesellschaft für Natur- and Völkerkunde Ostasiens, 1984.

Liew Foon Ming (劉罳明). “The Luchuan-Pingmian Campaigns (1438-1449) in the Light of Official Chinese Historiography”. Oriens Extremus, Vol. 39 (1996), pp. 162-203.

Ma Jianxiong. "Zhaozhou Bazi Society in Yunnan: Historical Process in the Bazi Basin Environmental System during the Ming Period (1368-1643)". In Ts'ui-jung Liu, Ed., Environmental History in East Asia: Interdisciplinary Perspectives. London: Routledge, 2014, pp. 131-155.

Ma Jianxiong 馬健雄. “Mingdai de Zhaozhou yu Tiesuoqing: Dianxi yi 'Bazi' wei zhongxin de dili huanjing yu zuqun jiangou 明代的趙州與鐵索箐: 滇西以 ‘壩子’ 為 中心的地理環境與族群建構 (Zhaozhou and Iron Chain Gorge in the Ming Period: The Geographical Environment of Basins and the Making of Ethnic Groups in Western Yunnan).” In Zhao Min 趙敏 and Wang Wei 王偉, Eds., Dali Minzu Wenhua Yanjiu Luncong 大理民族文化研究論叢 (Collected Research Articles on Dali Ethnic Groups and Culture), No. 6. Beijing: Minzu Chubanshe, 2017, pp. 229-262.

Millward, James A. Beyond the Pass: Economy, Ethnicity, and Empire in Qing Central Asia, 1759-1864. Stanford: Stanford University Press, 1998.

Okuyama Norio 奥山憲夫. Mindai Gunseishi Kenkyu 明代軍政史研究 (Research on the History of Military Administration in the Ming Period). Tokyo: Kyūko Shoin, 2003.

Peng Gang 彭綱 and Zhou Jifeng 周季鳳. Zhengde Yunnan Zhi 正德雲南志. Preface 1510 (Zhengde 5). In Tianyige Cang Mingdai Fangzhi Xuankan Xubian 天一閣藏明 代方志選刊續編, 70 \&71. Shanghai: Shanghai Shudian, 1990.

Perdue, Peter C. China Marches West: The Qing Conquest of Central Eurasia. Cambridge: Belknap Press of Harvard University, 2005.

Scott, James C. The Art of Not Being Governed: An Anarchist History of Upland Southeast Asia. New Haven and London: Yale University Press, 2009.

Taizu Shilu 太祖實錄. Taibei: Guoli Zhongyang Yanjiuyuan Lishi Yuyan Yanjiusuo, 1962.

Tang Li 唐立 (Christian Daniels). "Tuliu jianzhi diqu de tuguan shizheng: yi Dianxi Menghua Fu Zuo shi tuguan wei li土流兼治地區的土官施政: 以滇西蒙化府左氏土 官為例”. Qingshi Luncong 清史論叢, No. 32 (2016), pp. 31-58.

Tsurumi Naohiro. "Rural Control in the Ming Dynasty". In Linda Grove and Christian Daniels, Eds., State and Society in China: Japanese perspectives on Ming-Qing Social and Economic History. Tokyo: University of Tokyo Press, 1984, pp. 245-277.

Von Glahn, Richard. The Country of Streams and Grottos: Expansion, Settlement, and the Civilizing of the Sichuan Frontier in Song Times. Cambridge and London: Council on East Asian Studies, Harvard University, 1987.

Wang Yuquan 王毓銓. Mingdai de Juntun 明代的軍屯 (Military Farming Colonies of the Ming Dynasty). Beijing: Zhonghua Shuju, 1965.

Yang Shiyu 楊世鈺 and Zhang Shufang 張樹芳, Eds. Dali Congshu Jinshi Pian 大理叢 書金石篇. Beijing: Zhongguo Shehui Kexue Chubanshe, 1993. 10 volumes.

Yu Zhijia 于志嘉. Mingdai Junhu Shixi Zhidu 明代軍戶世襲制度 (The Hereditary System of Military Households in the Ming Period). Taibei: Taiwan Xuesheng Shuju, 1987. 


\title{
1 Salt, grain and the change of deities in early Ming western Yunnan
}

\author{
Zhao Min
}

\section{Introduction}

The Ming conquest of 1382 marked the beginning of the transformation of local society in Yunnan. The Mongol-Yuan relied heavily on the Duan 段, descendants of the royal family of the Dali kingdom (937-1253), to administrate local society in western Yunnan. The first Ming Emperor, Zhu Yuanzhang, continued many Mongol-Yuan administrative policies in Yunnan. His practice of appointing local ethnic leaders as native officials (tuguan 土官) to administer ethnic populations is well known. In addition, he implemented novel measures that became catalysts for change at the level of local society. One such case was the establishment of Guards and Battalions (weisuo 衛所) to control local society and to prevent unrest by indigenous peoples, particularly those inhabiting the borders with Southeast Asia. The Mongol-Yuan had also stationed troops in Yunnan. However, the Ming innovated by establishing a system for delivering grain to the troops. The early Ming state solved the problem of provisioning the Guards and the Battalions in border areas through two methods. The first was to set up military colonies (tuntian 屯田), while demobilising seven out of every ten soldiers to grow food for the army. The other method, known as the salt-barter system (kaizhong $f a$ 開中法), involved incentivising merchants to deliver grain to Guard granaries in return for lucrative licences to sell government salt. The salt-barter system triggered a series of changes that played a part in the transformation of pre-1382 local society into something more akin to that of other Ming-administered provinces in Southwest China.

This chapter traces the introduction of the salt-barter system, paying particular attention to the way in which external factors, such the war with the Tai polity of Mäng $^{2}$ Maaw $^{2}$ (Ch: Luchuan 麓川) and the price of grain, required the Ming to improvise and compromise with local elites to maintain food supplies to the Guards and Battalions. I argue that the solution for provisioning the military adopted by the Ming, particularly the mobilisation of local power holders in western Yunnan to maintain the system, inadvertently created a new political, social and economic environment in local society. Through a case study on the changed identity of a tutelary deity in Yunlong county 雲龍縣 known as Sanchong 三崇, I demonstrate that the transformation of local society extended to the sphere of local religious beliefs. 


\section{The salt-barter system and the military in Yunnan}

Chinese dynastic states monopolised the production and sale of edible salt from ancient times. Recognising salt as a commodity essential for human existence, the state of Qin monopolised its production from the Warring States period (480-221 BC). The Chinese state oversaw salt production in Yunnan from early times. The Western Han dynasty (202 BC-AD 9) appointed officials to oversee salt production at Lianran 連然 (today's Anning 安寧 near Kunming). During the Eastern Han (AD 25-220), Zheng Chun 鄭純, the Governor of Yongchang 永 昌, exacted taxes from salt wells located along the River Bi 沘江 in Yunlong and Lanping 蘭坪. Zheng Chun compelled local magnates (yihao 邑豪) to submit two sets of pull-over shirts (guantou yi 貫頭衣) and one $h u$ 斛 (100 litres) of salt every year as regular tax. ${ }^{1}$ The Nanzhao and Dali kingdoms regulated the supply of salt to maintain a tight hold over the indigenous population. The Nanzhao kingdom gained dominance over the salt pools (yanchi 鹽池) in Yanyuan 鹽源 county in today's Sichuan in 794 (Zhenyuan 1) after a long struggle with the Tang dynasty and the Tubo 吐蕃. ${ }^{2}$ The Mongol-Yuan established a Commissioner for Salt Transit Taxes (Yanque shi 鹽榷使) on the Dali Route 大理路 to collect tax on salt and a Supervisor of the Salt Commission (Tiju Yanshi si 提舉鹽使司) on the Weichu Route 威楚路 to administer the Black Salt Well 黑鹽井. However, the various dynasties that controlled Yunnan had not formulated a comprehensive system for regulating salt production before the Ming.

As elsewhere in the country, the early Ming used the salt-barter system to deliver grain to the Guard and Battalions in Yunnan. The Ming mobilised 300,000 soldiers to conquer Yunnan, and the military soon faced food shortages. The situation proved so desperate that during the second lunar month of 1382 (Hongwu 15), Zhu Yuanzhang, the founding Emperor, instructed the Ministry of Revenue "to order merchants to deliver grain to Yunnan in exchange for salt in order to supply" the military with food. ${ }^{3}$ The Ministry of Revenue clearly stipulated the exchange rate of grain for salt for different delivery points in the province at that time as follows:

For transportation to Yunnan, 200 catties (jin 斤) of Huai salt 淮鹽 will be issued for bringing $6 \mathrm{dou}$ 斗 of rice; 200 catties of Zhejiang salt 浙鹽 will be issued for bringing 5 dou of rice; and 200 catties of Sichuan salt 川鹽 will be issued for bringing $1 s h i$ 石 of rice. For transportation to Pu'an 普 安, 200 catties of Huai and Zhejiang salt will be issued for bringing $6 \mathrm{dou}$ of rice; 200 catties of Sichuan salt will be issued for bringing 2 shi 5 dou of rice. For transportation to Puding 普定, 200 catties of Huai salt will be issued for bringing $5 \mathrm{dou}$ of rice; 200 catties of Zhejiang salt will be issued for bringing $4 \mathrm{dou}$ of rice; for Sichuan salt the regulation used in Pu'an applies. For transportation to Wusa 烏撒, 200 catties of Huai and Zhejiang salt will be issued for bringing 2 dou of rice; for Sichuan salt the regulation used in Pu'an applies. ${ }^{4}$ 
The Ming Shi records the personal role played by Zhu Yuanzhang, noting particularly his instructions "for drawing up regulations for controlling salt, for establishing government organs and setting up officials". It specifically mentions him "decreeing that the state would take one-twentieth of the sales by merchants to provide supplies for the armies". ${ }^{5}$ These regulations were aimed to systematise the salt-bartering method that supported the Ming military in extending and maintaining control in Yunnan.

The salt-barter system commenced in Shanxi province in 1370 (Hongwu 3), twelve years before the conquest of Yunnan. Zhu Yuanzhang approved a request to make merchants responsible for delivering grain to state granaries in exchange for salt licences ( yanyin 鹽引). Merchants could obtain salt when they presented the licence slips (yinpiao 引票) issued by officials at designated locations. Since this system saved the state the cost of transporting grain and supplied the military with food at the same time, Zhu Yuanzhang ordered its implementation empire-wide. ${ }^{6}$

In essence, the salt-barter system enabled the Ming state to closely control the production and sale of salt while ensuring the provisioning of the military. The system functioned in the following way. The state issued salt licences, and every licence ( $y$ in引) entitled the merchant to sell a certain amount of salt while at the same time requiring him to deliver a specific amount of grain. After delivering the grain to the designated granary or yamen, the merchant received the salt licence in exchange and proceeded to the location designated on the licence to collect the stipulated amount of salt. Then, the merchant sold the salt for profit in the area designated on the licence. The state issued standard licences for 400 catties of salt although it issued smaller licences for 200 catties during the Hongwu reign (1368-1398). The exchange rate of grain to salt in the licenses fluctuated depending on the distance travelled and licence type.

To ease the difficulty of supplying food for the large numbers of troops sent to suppress rebellions by ethnic peoples, the Ming state made officials in border areas responsible for the salt licences. This arrangement aimed to encourage merchants to transport grain to distant locations and profit from selling salt there. To function successfully, the arrangement depended on the taste of merchants for profit. Since the Ming state benefitted from not having to bear the transportation costs of both the rice and the salt, it continued to use the salt-barter system in conjunction with the institution of military state farms (juntun 軍屯) to ensure that the Guards and Battalions had sufficient food supplies after the conquest of Yunnan.

The influx of soldiers into Yunnan placed pressure on food supplies during the early Ming. After establishing the Yunnan Provincial Administration Commissioner (Yunnan Dengchu Chengxuan Buzheng Shishi 雲南等處承宣布政使 司), Zhu Yuanzhang settled Mu Ying 沐英 and several hundred thousand soldiers in Yunnan as a defence force and established large numbers of military state farms to provide food for them. However, the grain produced at military state farms proved insufficient. Therefore, the state had to rely on the salt monopoly as a solution and began to recruit merchants to deliver grain in exchange 


\section{Zhao Min}

for salt from 1382. In a memorial dated the second lunar month of 1382, Fu Youde 傅友德, the General for Conquering the South 征南將軍, suggested a number of ways to feed the soldiers. Fu Youde requested the garrisoning of soldiers in Yunnan to guard strategic positions. The soldiers came from Jiangxi 江 西, Zhejiang 浙江, Huguang 湖廣, Henan 河南 and Sichuan 四川. However, noting the inadequacy of the grain reserves at the Guards and Battalions, he suggested a number of means to make up the food shortage as follows:

Turning [the land of] former state monasteries and cloisters (guansiyuan 官 寺院) into state land (guantian 官田), appropriating the taxes collected from the prefectures, sub-prefectures (zhou 州) and counties this current year, as well as making use of taxes paid by native officials, grain delivered by salt merchants, and the harvests from military farming colonies of garrison troops (shubing tuntian 戊兵屯田). ${ }^{7}$

$\mathrm{Fu}$ Youde's request to use all available state income and resources indicates the severity of the food crisis in 1382.

To make the salt-barter system function, the Ming had first to secure control over the salt production in Yunnan. The Ming established four Salt Distribution Supervisorates (Yanke Tiju Si 鹽課提舉司) at Black Salt Well, White Salt Well 白鹽井, Anning Salt Well and Wujing 五井 (located in Yunlong county: see Map 1.1). The Ministry of Revenue determined that the salt-barter system would be implemented first at the Anning Salt Well, stipulating as follows:

Two hundred catties of Anning salt will be issued to recruited merchants who transport $3 \mathrm{shi}$ of rice to Yunnan and Lin An, 2 shi 8 dou of rice to Wusa and Wumeng 烏蒙, 3 shi 5 dou of rice to Zhanyi 沾益 and Dongchuan 東川, 2 shi 8 dou to Qu Jing and 1 shi 8 dou of rice to Pu'an. ${ }^{8}$

At that time, the Ming had six Salt Controllers (Yanyun Si 鹽運司) and seven Salt Distribution Supervisorates over the entire country, with four Salt Distribution Supervisorates located in Yunnan. Merchants transporting grain to Yunnan traded salt produced at the wells in Anning, Wujing and the Black Salt Well and only sold it within Yunnan. ${ }^{9}$ The Ming court utilised Yunnan salt as part of an exchange system to support the military forces that guarded against intrusions by ethnic peoples on the southwest border.

\section{The Mäng ${ }^{2}$ Maaw $^{2}$ campaigns, the grain supply and local magnates}

At first, the Ming restricted the use of the salt-barter system to Guards and Battalions in eastern and central Yunnan, at locations such as Lin'an, Wusa, Wumeng, Zhanyi, Dongchuan and Qujing. These military institutions occupied vital positions on the transportation routes and served as strategic sites for pacifying the entire province. In time, large numbers of Han troops from Central China settled 


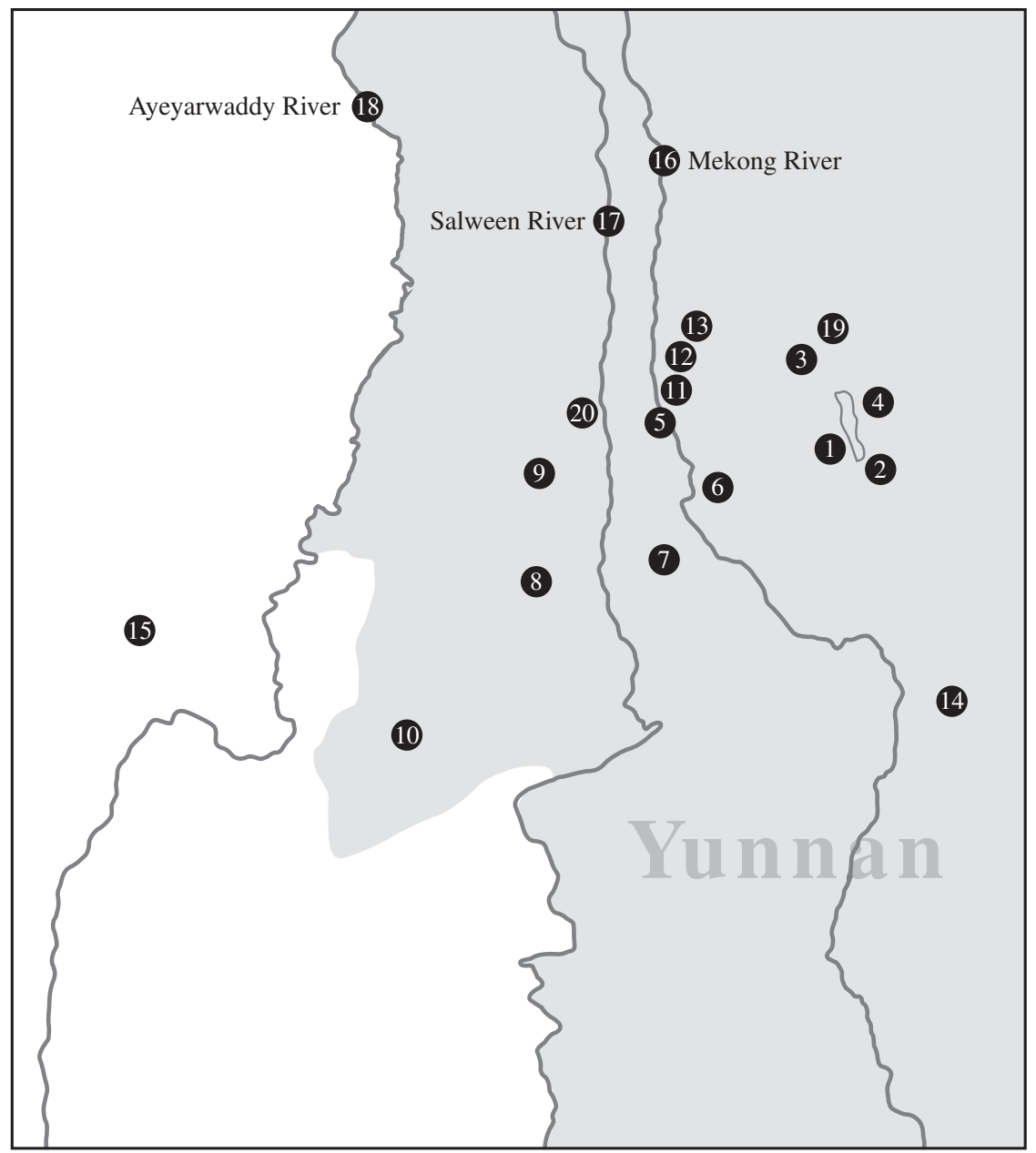

\begin{tabular}{|c|c|c|}
\hline $\begin{array}{l}\text { ali 大理 } \\
\text { naozhou 趙州 } \\
\text { angqiong 浪穹 } \\
\text { t. Chicken Foot 雞足山 } \\
\text { Inlong 雲龍 } \\
\text { ngping 永平 } \\
\text { ngchang 永昌 }\end{array}$ & $\begin{array}{l}8 \text { Tengchong Guard (Tengyue) } \\
\text { 騰衝衛/騰越 } \\
9 \text { Mingguang 明光 } \\
\text { (10 Mäng² Maaw² (Luchuan) } \\
\text { (11) Wujing 五井 } \\
\text { (12) Shijing 師井 } \\
\text { (13) Shundangjing 順蕩井 } \\
\text { (14) Jingdong 景東 }\end{array}$ & $\begin{array}{l}15 \text { Meng Yang 孟養 } \\
16 \text { Mekong River 瀾滄江 } \\
17 \text { Salween River 怒江 } \\
18 \text { Ayeyarwaddy River 大金江 } \\
19 \text { Foguang stockade 佛光寨 } \\
20 \text { Gaoligongshan Mountains } \\
\text { 高黎貢山 }\end{array}$ \\
\hline
\end{tabular}

Map 1.1 Western Yunnan, 1582. 


\section{Zhao Min}

in Yunnan, placing pressure on the living space of indigenous people. During the Xuande era (1426-1435), the focus of the salt-barter system shifted from eastern and central Yunnan to Dali, Yongchang and Tengchong 騰衝 on the military front in western Yunnan in preparation for punitive expeditions against the belligerent Tai polity of Mäng ${ }^{2} \mathrm{Maaw}^{2}$. At that time, although merchants found the transportation of grain to border areas under the salt-barter system increasingly less attractive, they continued to transport salt to Yunnan. Thus, the barter system remained strong there. As a result, the Ming court used the salt-barter system as a crucial strategy for managing Yunnan and an indispensable means to provide food supplies to troops in the province for an extended period of time. During the fifth month of 1427 (Xuande 2), the Ministry of Revenue received a document from the Yunnan Provincial Administration Commissioner reporting a shortage of grain for the troops in Yunnan. The document explained that this deficiency arose because of an increase in the price of rice and a decrease in the price of salt as follows:

In the past, the salt-barter method was used to exchange Anning Well salt [for transported grain]. One yin was issued for $2 \mathrm{shi}$ of rice received. Now that the price of rice has risen and that for salt has gone down, travelling traders no longer come. It is requested that the amount could be lowered. For salt produced at Anning, one Yin would be issued for every 1 shi 2 dou of rice instead, and 1 shi of rice for salt produced at the Black Salt Well and the White Salt Well. The grain had to be delivered to the granary at the Jinchi Military-cum-Civilian Military Command 金齒軍民指揮司, and salt could be claimed at any time. ${ }^{10}$

This request was approved and put into practice. However, in 1431 (Xuande 6), the Ming discontinued the salt-barter system in the entire country with the exception of Beijing. Facing an acute shortage of grain, the Yunnan Provincial Administration Commissioner petitioned the court for special consideration. The request read as follows:

The border areas of Yunnan used to annually issue salt licences to travelling merchants who delivered rice to granaries in places such as Dali and Jinchi in exchange for salt produced at Anning and other salt wells. Now that this method has been discontinued, the supply [of grain] is no longer sufficient to meet the demand. We request that [Yunnan] still be permitted to recruit merchants to transport rice to exchange for salt and that [the exchange rate] at Anning and other salt wells follow the regulations laid down in 1428 (Xuande 3) and that [the exchange rate] at Huai and Zhe follow the regulations of the Hongwu era. ${ }^{11}$

The granting of special approval by the Xuanzong Emperor ensured the continuation of the salt-barter system in Yunnan. The Emperor's decision may have been influenced by the constant threat of war with the Tai polity of Mäng ${ }^{2}$ Maaw $^{2}$ that dominated parts of southwest Yunnan and northern Myanmar. 
Si Renfa 思任發, the paramount leader of Mäng ${ }^{2} \mathrm{Maaw}^{2}$, attacked parts of Yunnan where the Tai resided in 1439 (Zhengtong 4). His forces raided Jingdong 景東 and plundered Meng Ding 孟定, killing over a thousand people, including Dao Fenghan 刀奉漢, the Prefect of Dahou 大侯. The Native Chief's office at Meng Lian 孟璉長官司 and several stockades at Meng Lai 孟賴 even surrendered to him. ${ }^{12}$ The Ming responded by dispatching punitive expeditions against Si Renfa, which expended large amounts of food and provisions and depleted grain supplies available to the military. The increase in rice prices made it unprofitable for merchants to engage in the salt-barter system. This circumstance prompted the Yingzong Emperor to approve the Yunnan Provincial Administration Commissioner's request to "transport silver notes" (yinchao 銀鈔) from the Commission's treasury to Jinchi and Dali for purchasing grain to keep in reserve. Additionally, Yingzong also approved the request to lower the exchange rate for rice to salt at Dali and Jinchi to benefit merchants. The new arrangement was as follows:

At Dali, one yin of salt from the four wells, including the Black Salt Well, was exchanged for 2 shi of rice; now it has been reduced to 1 shi $5 \mathrm{dou}$ instead. At Jinchi, one yin of salt from the five wells of Anning was exchanged for 1 shi 2 dou; now it has been reduced to 1 shi instead. One yin of salt from the Black Well and White Well was exchanged for 1 shi; now it has been reduced to 8 dou instead. ${ }^{13}$

The Ming court appointed Mu Ang 沐昂 General for Conquering the South and Regional Commander (zongbingguan 總兵官) of the punitive expedition sent against Si Renfa, on the third day of the fifth lunar month in 1439 (Zhengtong 4). ${ }^{14}$ In the sixth lunar month, the Ming reinstated the salt-barter system in Yunnan. To meet the needs of the expedition, the Ming recruited merchants to transport rice to Dali and Jinchi to exchange for salt. However, the price of rice rapidly increased because of the prolongation of the campaign and the reluctance of merchants to transport grain. To alleviate the situation, the relevant officials adjusted the exchange rate: "one salt yin from Salt Distribution Supervisorates at the White Salt Well and the Wujing Salt Well would be issued to merchants who transported 2 dou of rice to Dali or $1.5 \mathrm{dou}$ of rice to Jinchi." 15 During the eleventh lunar month of 1439, the Ming was forced to reduce the exchange rate of rice to salt to an even lower level to ensure the delivery of grain. Now, merchants received one yin of salt from Sichuan for transporting only $1.5 \mathrm{dou}$ of rice to Dali and the same amount of salt for transporting only $1 \mathrm{dou}$ of rice to Jinchi. ${ }^{16}$ This change represented a reduction of $0.5 \mathrm{dou}$ rice for delivery to both locations within five months. The Ming desperately tried to attract more merchants to participate in the saltbarter system by lowering the ratio of rice to salt. It also emphasised how the immense cost of the military campaigns against Mäng ${ }^{2} \mathrm{Maaw}^{2}$, with large numbers of troops garrisoned in western Yunnan, aggravated the food shortage in the province. 
Ten years later, the price of salt licences again increased to a great height. Local magnates in western Yunnan seized the opportunity to monopolise the sale of salt licences and rice. They found the salt-barter system appealing. A report from Yongping county in the sixth lunar month of 1449 (Zhengtong 14) reveals that merchants bought salt licences with silver, a practice condoned by Ming authorities. The report stated as follows:

The salt from the Wujing is exchanged for rice by magnates (haoyou 豪右) from Jinchi and other places. Every salt licence is worth 2 to 3 shi of rice, even though only 5 to $6 \mathrm{dou}$ are delivered. Recently, soldiers and civilians in Yongping willingly pay 3 taels of silver for every salt licence, and the purchased rice is delivered to the Jinchi granary. ${ }^{17}$

The salt-producing area closest to the war zone was the Wujing wells (literally Five Wells) in today's Yonglong county. It was administered by the Salt Distribution Supervisorate. The exchange rates for salt and rice at the Wujing wells, which were close to Yongping county, were far better than at the Black Well and the White Well salt areas and infinitely superior to the salt hauled long distance from Huai, Zhejiang and Sichuan. At that time, a licence for Wujing salt was "worth 2 to 3 shi of rice". However, in reality, licence holders only delivered 5 to $6 \mathrm{dou}$; thus, profits reached as high as 2 shi $5 \mathrm{dou}$. The lucrative exchange of Wujing salt for grain was monopolised by magnates from Jinchi (today’s Baoshan 保山). In essence, this phenomenon reveals that the escalation of warfare with Mäng ${ }^{2} \mathrm{Maaw}^{2}$ and the increasing costs of provisioning the military with grain under the salt-barter system caused a sharp increase in both salt and rice prices. Holding surplus silver, local civilians and military households in the vicinity of Yongping county found it lucrative to purchase rice to participate in the salt-barter system.

\section{Native officials and local magnates as grain suppliers}

By monopolising salt production, the Ming did not intend to protect the interests of consumers. Rather, the state aimed to recruit merchants to distribute salt on their behalf to reduce transportation costs. This arrangement enabled the Ming to regulate salt supplies to the civilian population and at the same time aided the provisioning of armies at border regions. Merchants willingly accepted the task of supplying grain to troops in border areas because the state granted them the right to sell salt and most importantly because they could profit from price margins. The delivery of a specific amount of grain for the military by state-recruited merchants was known as baozhong 報中 (reporting for exchange). During the mid-to-late Ming, the sites for baozhong in Yunnan were the farming colonies (tun 屯) attached to the Guards and Battalions (weisuo 衛所), whose sites could change according to the location of military campaigns undertaken to suppress revolts by ethnic peoples and the places in which disturbances arose in border areas. The need for suppliers to traverse high mountains and cross deep valleys 
to reach the border regions of Yunnan increased the price of rice. The longer that the journey was, the higher the price. The salt-barter system undeniably contributed immensely to the provisioning of the military and fostered economic growth at the borders in Yunnan. However, we should not overlook that the saltbarter system was unable to supply the military there with sufficient grain. Under the salt-barter system, the motivation for merchants to deliver could easily change according to economic conditions. In a memorial of 1437 (Zhengtong 2), the Yunnan Provincial Administration Commissioner reported as follows:

Vast amounts of food and provisions have been consumed during the military campaigns against Luchuan, but the transport of warehoused grain has failed to cover the losses. Though there are regulations for the grain/salt exchange rate, soaring rice prices have reduced the number of merchants coming to exchange [grain] for salt. ${ }^{18}$

With fewer merchants delivering grain, large quantities of salt lay in store for a long time, which rendered the salt-barter system increasingly less sustainable.

To relieve the worsening problem of grain shortage created by the campaigns against Mäng ${ }^{2} \mathrm{Maaw}^{2}$, the Ming court adopted the exceptional measure of rewarding and promoting those who donated grain to the military with official posts. Lai Xun 賴巽, the Surveillance Commissioner of Yunnan, requested the implementation of this arrangement in a memorial dated the seventh lunar month of 1439 (Zhengtong 4), in which he provided the following detailed description:

Recently, it has become difficult to deliver provisions to the army fighting Si Renfa, the rebel bandit of Luchuan, so we have already started to recruit merchants to deliver grain in exchange for salt. The [Yunnan] Provincial Administration Commissioner has already been instructed to use military silver (junyin 軍銀) for purchasing rice. Nevertheless, the price of rice is high, and few merchants come to exchange for salt. At present, troops in the Guards (Wei) and local people (turen 土人) at Dali and elsewhere stockpile great quantities of grain at home. Henceforth, military officers and native officials who are able to deliver 200 shi of rice to the granaries at Jinchi will be promoted one grade, and those who deliver 300 shi will be promoted two grades. Local people who deliver 200 shi of rice will be rewarded with official positions such as Aides to Postal Relay Stations (Yicheng 驛丞) and Fishing Tax Offices (Hebo 河泊), while soldiers who deliver the same amount will be given positions as Judges (Zhenfu 鎮撫) in the Guards. Those who deliver 300 shi will be appointed as Vice Magistrates (Xianzuo 縣佐) and Military Inspectors (Xunjian 巡檢) if they are local people, and Probationary Company Commanders (Shi Baihu 試百戶) if they are soldiers. In this way, people will be spared the trouble of transporting the grain, the state will not lose money, and the supply of grain and provisions will be sufficient [for the needs of the army]. ${ }^{19}$ 
Because of the emergency situation, the Ming offered rewards to military officers in the Dali Guard, as well as native officials and local magnates, if they delivered grain for the army. The state rewarded them with official positions and promotions to different grades according to the quantities of grain delivered. Imperial bureaucrats introduced these desperate measures at Dali due to its proximity to the front in the war against Mäng ${ }^{2} \mathrm{Maaw}^{2}$.

Fifteen years later, in 1454 (Jingtai 6), fifty-four powerful officials (guanhao 官豪) at Tengchong, including Commander Chen Sheng 陳昇, “appropriated and cultivated military farming colonies (tuntian 屯田) in the vicinity of the walled city". After an investigation into this malpractice, the state pardoned the officials involved and distributed the land to soldiers for cultivation. ${ }^{20}$ This incident reveals the contradictory situation created by the campaign against the Tai polity. While the state faced an emergency in provisioning the army and Yunnan suffered from an increasingly acute shortage of food, military officers in the Guards and Military-cum-Civilian Military Command prefectures, native officials and local magnates in western Yunnan took advantage of their power and influence to seize military farmland laid waste by the mobilisation of the soldiers for battle. By false reporting, these individuals secretly amassed large quantities of grain at their homes, and because of the short supply, they sold grain at highest price only. They turned a blind eye to the urgent needs of the state for grain.

The practice of rewarding individuals with official positions for delivering grain to the military was tantamount to the state procuring grain by the sale of ranks and titles. The Ming court had increasingly become dependent on military officers in the Guards and Battalions, native officials and local magnates for the supply of military power and provisions. As the main suppliers of grain to the military, native officials and local magnates rose to prominence and later became an influential socio-economic force in Yunnan. Although the Ming court knew that certain native officials oppressed their people, it took no action against them because of anxiety over the vitally important issue of provisioning the military. For instance, in 1451 (Jingtai 2), Mu Lin 沐璘, the Regional Commander and Vice-Commissioner-in-chief, promoted Dong Zhen 董禎 “the Native Police Chief” (Tuguan Xunjian 土官巡檢) of Zhaozhou 趙州 (today’s Fengyi zhen 鳳(儀鎮) in Dali prefecture, to a higher rank despite complaints from 750 individuals that Dong had treated them brutally and unreasonably. $\mathrm{Mu}$ Lin ignored these protests by local people because Dong Zhen and his brother had donated grain to Guizhou. ${ }^{21}$ From the outset, official magnates (guanhao 官 豪) gained power and influence because of the state's urgent need for rice and provisions. An ethnic Tai family, the A 阿氏, acquired the hereditary post of sub-prefectural Native Magistrate in Dengchuan Zhou 鄧川 (in today's Eryuan county) during the Hongwu period because a family forebear "led his people in transporting grain". ${ }^{22}$ The Shi family 施氏 attained its position as hereditary Native Company Commander (Tu Baihu 土百户) in Dengchuan sub-prefecture because an ancestor provided "truly commendable meritorious service" to the Ming by "transporting provisions" at the time of the conquest. ${ }^{23}$ 
With their eyes fixed on the opportunities, imperial rotating officials (liuguan 流官) also joined in the scramble. Colluding with native officials and local magnates, they distorted facts to suit their own purposes and sought large profits and agricultural land to appropriate. For instance, take the case of Yongchang prefecture. The throne approved the request by Hu Yuan 胡淵, the Commander of the Jinchi Guard, to convert the Guard into a Military-cum-Civilian Military Command responsible for administrating both the military and the civilians. $\mathrm{Hu}$ Yuan based his request on the claim that Jinchi had a small population and insufficient supplies of grain. However, officials and eunuchs who arrived later profited from resources there. This fact casts doubt on the veracity of his claim. He Mengchun 何孟春 (1474-1536), who served as Grand Coordinator of Yunnan 雲南巡撫 during the Zhengde era (1506-1521), recorded the arrival of the first eunuch Mao Sheng 毛勝 at Jinchi and the activities of other eunuchs who followed in his wake as follows:

At the end of the Jingtai era, Mao Sheng, the Commissioner-in-chief (Dudu 都督) came with the punitive campaign against Luchuan, and he ensconced himself as the Grand Defender (Zhenshou 鎮守) because he noticed that Jinchi had abundant [taxable] resources under its jurisdiction. Seeing that Mao Sheng had profited greatly, other eunuchs came following on his heels. They appropriated many wet fields from the indigenous people (yitian 夷 田) and turned them into official manors (guanzhuang 官莊), and they used the property of the indigenous people (yicai 夷財) to pay for their own expenses. $^{24}$

Although $\mathrm{Hu}$ Yuan claimed a shortage of grain and provisions as the reasons for the administrative reform, his real motive lay in expanding the scope of his powers of governance as Commander of the Military-cum-Civilian Military Command, a hereditary position. By invoking the need to ensure the delivery of grain to the military as a valid justification, he was able to exploit the situation for his own benefit. The eunuchs dispatched by the court to attend to political, military and economic activities at Jinchi and Tengyue also took advantage of the situation to line their pockets. Because the post of Grand Defender (Zhenshou 鎮守) at Jinchi became a lucrative post, eunuchs at court vied with one another for appointment to the position, and with no one on the spot to control their behaviour, they appropriated agricultural land from the indigenous people in the border area.

\section{Impact on local society}

The salter-barter system linked the two basic commodities of salt and rice, thus giving the Ming state control over people's livelihoods. For reasons already explained, the use of the salt monopoly to deliver grain to the military in western Yunnan resulted in high prices for both these commodities. In the process, the significance of salt underwent a drastic change at the Wujing salt wells in 
Yunlong county. Although the state controlled the salt, it was the merchants who had come to profit by selling it through the salt-barter system, which resulted in intensified competition in society for these commodities. Since both salt and rice were expensive commodities, certain individuals generated wealth by hoarding rice, while others became rich because they had access to salt.

The Ming established a Salt Distribution Supervisorate at Langqiong county 浪穹縣 in Dali prefecture in 1383. Since this Supervisorate administered five wells, it was known as the Wujing (literally Five Wells) salt-producing area. The Supervisorate was subdivided into five Salt Tax Offices (Yanke si 鹽課司), many of which were located in Yunlong county: Nuodeng 諾鄧, Dajing 大井, Shijing 師井, Shundang 順蕩 and Luoma 落馬. Li Yuanyang (1497-1580) described the organisation of the staff, the location of each well and the annual revenue in the sixteenth century as follows:

There is one Supervisor (Tiju 提舉) and one Chief of Police (Limu 吏目) [at Langqiong]. The Salt Tax Offices at Nuodeng, Dajing, Shijing and Shundang each have one Commissioner (Dashi大使). For the location of the wells, Nuodeng well lies in front of the Salt Distribution Supervisorate yamen; Dajing lies 10 li southeast of the Salt Distribution Supervisorate yamen; Shimen well 石門井 lies ten $l i$ southeast of the Salt Distribution Supervisorate yamen; the Luoma, Shifeng 石綘井, and Hebian 河邊井 wells all lie $50 \mathrm{li}$ south of the Salt Distribution Supervisorate yamen. The annual tax collected by the Salt Distribution Supervisorate totals 4475.5465452 taels (in leap years) and 4131.2725 taels (in non-leap years). ${ }^{25}$

The 1694 Dali prefecture gazetteer recorded that the prospect of profits had lured Han people from all four quarters of the empire to come and settle at the Luoma well in Yunlong county. After time, they became local people (tuzhu 土 著), and "their talented descendants gradually immersed [themselves in education], becoming official families of civil and military scholars (yiguan wenwu zhi $s h i$ 衣冠文武之士)" ${ }^{26}$ Merchants visiting the Wujing salt wells under the saltbarter system boosted the scale of salt production and attracted more people to the area, thus promoting economic and cultural interflow between Yunlong and Central China. Profits generated from salt altered the population structure; Han migrants became indigenous people, while the indigenes imitated the Han. Male family members of local magnates could rely on capital accumulated from salt trading to compete in the civil service examinations. Through this process, local magnates transformed themselves into "official families of civil and military scholars", thus gaining admission into the hierarchy of the privileged group.

Native officials enthusiastically engaged in the tribute system, travelling to the capital to pledge their allegiance by paying tribute. The Veritable Records of the Ming record that even low-ranking native officials in charge of salt wells in Yunlong submitted tribute. Yang Sheng 楊勝 and Sun He 孫和, native officials at the Police Office (Xunjian Si Tuguan 巡检司土官) at the Shijing well, and 
Yang Jian 楊堅, a Native Official at the Salt Tax Office at Shanjing 山井 well (today's Shanjing village 山井村 in Yunlong county) arrived at the capital bringing horses as tribute during the eighth lunar month of 1425 (Hongxi 1). ${ }^{27}$ Yang Xingyong 楊星勇 and Sun Chun 孫春, former Native Official Vice Commissioners (Tuguan Fushi 土官副使) of the Salt Tax Office at Shundang, arrived at the capital to offer horses as tribute during the second lunar month of 1431 (Xuande 6). ${ }^{28}$ Duan Jie 段節, Native Official of Zhennan sub-prefecture 鎮 南州, and Li Xiang 李祥, a Bashi 把事 in Yunlong sub-prefecture, submitted horses as tribute during the second lunar month of 1435 (Xuande 10) and were provided various gifts in return. ${ }^{29}$

The Ming court clearly understood the characteristics of the native officials and their niche in Yunnan. The authors of the Ming Shi explain that the Ming expanded on the Yuan dynasty's policy by appointing native officials in prefectures, sub-prefectures and counties and drawing up regulations concerning quotas for the submission of land taxes and labour service, as well as the deployment of troops. While recognising the merits and demerits of the native official system, they noted its value as a method for restraining the indigenous leaders of the southwest as follows:

The way lies in the halter-and-bridle method (jimi 羈縻). The great surnames act as they please and have used force to threaten [to abrogate] agreements for generations. We must confer our titles and ranks on them, favour them with official names, in order to easily dominate them. In this way, they serve us in compliance with our commands. ${ }^{30}$

Despite the transition from the Yuan to the Ming, social stratification in local society remained unshaken. As a privileged group, the new dynastic rulers and the local magnates joined together to gain benefits from vital material resources. Although the Ming expanded on the native official system practised during the Yuan period, it did not make significant changes to the social structure that allowed upward movement in society. The Ming Huiyao states as follows:

In 1374 (Hongwu 7), the barbarians from the southwest came to pay tribute. [The state] conferred on most the titles that they held during the Yuan period and attempted to restrain them by laying down regulations on the collection of labour and conscript service. ${ }^{31}$

In 1381 (Hongwu 14), when Ming armies marched towards Yunnan, the native officials under Mongol-Yuan rule successively surrendered. The Ming court reappointed most of them to their original posts, generously "conferring [previous] titles and ranks on them" and "favouring them with official names". Many indigenous magnates of the Mongol-Yuan period willingly submitted to the Ming because the new dynasty recognised their roles as leaders of local society. The halter-and-bridle method (jimi 羈縻) policy used by the Ming in Yunnan was essentially aimed at containing and restraining indigenous magnates. 


\section{Zhao Min}

The Ming widely adopted the salt-barter system in Yunnan to aid the pacification of the indigenous peoples and bring order to border areas. However, when the barter arrangement failed to function as expected and the continuance of the war with Mäng ${ }^{2}$ Maaw $^{2}$ caused the prices of both rice and salt to escalate, the Ming sought ways to persuade local magnates to co-operate by parting with the grain they stockpiled at home. It was only by "conferring titles and ranks" on native officials and local magnates and through the purchase of grain with silver that the Ming could relieve food shortages at the front. In this sense, the native official system proved highly successful for the Ming.

\section{Changed identity of the Sanchong Deity}

After the conquest of 1382, the Ming state did not seek to overturn the social structure of indigenous society in western Yunnan. Instead, it increasingly came to rely on the power of local magnates to control the indigenous people. This practice forced local magnates to realise they needed to reconstruct and redefine their legitimacy as new power holders in changed times. For the new magnates at the Wujing salt wells in Yunlong, which was the main group providing grain through the saltbarter system to the army campaigning against $\mathrm{Mäng}^{2} \mathrm{Maaw}^{2}$, the re-interpretation of their legitimacy as power holders became a particularly urgent issue because they desperately needed to secure support from the area's local people. The way the new Wujing magnates re-interpreted history was truly amazing. They quietly replaced the existing protective god in the territory of the Zuo Family Native Official 左氏土官 with a completely new deity. Local magnates replaced the original god, known as the State Founding Chicken Foot Emperor (Jianguo Jizu Huangdi 建國雞足皇帝), with Wang Ji 王驥 (1378-1460), the celebrated Minister of War (Bingbu Shangshu 兵部尚書) who defeated Mäng² Maaw ${ }^{2}$. Wang Ji had a long military career serving in punitive campaigns at the borders in both North and South China. He became Right Vice-Minister of War in 1427 and was formally promoted to Minister of War in 1434. He appeared as a new deity in areas administered by the Zuo family in the Wujing salt zone, at the Yunlong sub-prefecture seat located at Caojian 漕澗, and in parts of Tengchong sub-prefecture. As a deity, Wang Ji left a deep mark on the respective local societies, which has lasted until today. At the Wujing salt well at Jiuzhou 舊州 (marked as Yunlong on Map 1.1) and at Mingguang 明光 (Tengchong), people still worship Wang Ji as their tutelary deity, and they regularly repair his temples, which are never short of worshippers who come to pay their respects by burning incense to him.

In his 1573 Comprehensive Gazetteer of Yunnan, Li Yuanyang recorded that the State Founding Chicken Foot Emperor was the original deity in Sanchong temples 三崇廟 as follows:

The Shrine of the Sanchong Deity 三崇神祠 rested on the slope of Sanchong Mountain in Yunlong sub-prefecture. It was built by Duan Wenxian 段文顯, the native magistrate during the Jiajing era (1522-1566), and sacrifices are made in spring and autumn twice every year. ${ }^{32}$ 
By the mid-Ming, Duan Wenxian, the Native Official of Yunlong sub-prefecture, had endorsed the Sanchong deity as the tutelary god of the area. The temple was constructed at the sub-prefecture seat (today's Jiuzhou, renamed Gongguo Bridge Town 功果橋鎮) on a slope at the foot of Sanchong Mountain on the west bank of the Mekong (Lancang) River (see Figure 1.1).

The following passage in the Sanchong Hao 三崇浩, a ritual text (keyi 科儀) from the Wujing salt well area, traces the origin of Sanchong to the Tang period:

Jizu 雞足, a spiritual peak set among lofty mountains and magnificent scenery, was born during the Tang period. Jizu supported the fortune of the country with unswerving loyalty and manifested itself as a divine being (sheng 聖) in Ming times. The utmost inner powers (zhide 至德) of Jizu constantly enrich the livelihood of the people, create abundant produce in the spring, mend damage wrought by disasters, and joyously fulfil numerous wishes. Jizu declares the transformability of all things (hua 化) on behalf of Heaven, supports good and eradicates evil while harmonising the sentiments of the people. Its merits are recorded on the watchtowers (que 閲) in the north, and it suppresses the southern lands from its position (wei 位). It possesses great pity, an immense ability to fulfil wishes, vast holiness and enormous compassion. The emperor has issued an edict conferring on it the title "Sanchong State Founding Chicken Foot People Protecting Emperor 三崇建國雞足佑民皇帝”.33

The Sanchong deity was a divine god originally viewed as the founding Emperor of the Dali kingdom (937-1253). According to this text, the deity was born during the Tang period and had "supported the fortune of the country with unswerving loyalty" ever since. Therefore, Sanchong must have been Duan Siping 段思平 (938-944), the founding Emperor of the Dali kingdom. During

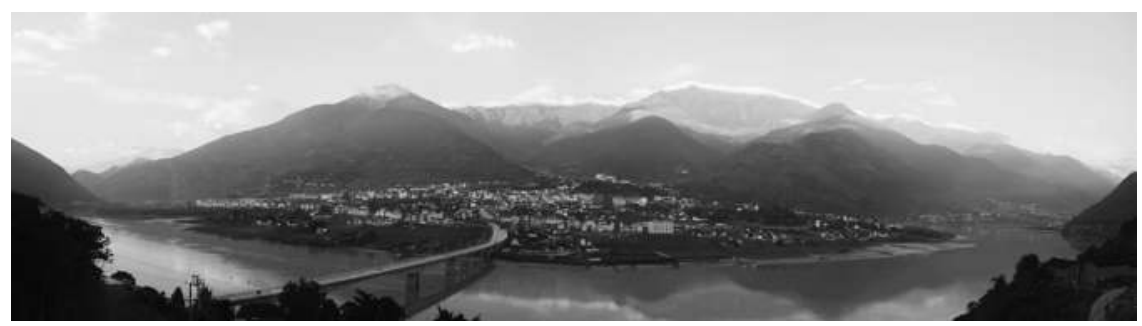

Figure 1.1 Jiuzhou nestled beside the Mekong River encircled by Sanchong Mountain.

The sub-prefecture seat of the native official of Yunlong was located here at Jiuzhou 舊州 at an elevation of 1,440 metres above sea level on the west bank of the Mekong River during the Yuan and Ming dynasties. The Shrine of the Sanchong Deity 三崇神祠 rested on the slope of Sanchong Mountain. Protected by Sanchong Mountain from behind and facing the Mekong, Jiuzhou was a strategic point on the route from western Yunnan to northern Myanmar.

Photograph: Zhao Min, 2019. 


\section{Zhao Min}

the Ming, the Sanchong deity once again "manifested itself as a divine being" but this time as Wang Ji 王焂, the Minister of War, not as Duan Siping. The text cited above indicates the substitution of Wang Ji for Duan Siping. Wang Ji rendered meritorious military service in the campaigns against the Mongols in the northwest on the Gansu frontier. Thus, the phrase "merits are recorded on the watchtowers (que 閭) in the north" refers to his role in these campaigns. The Ming History recorded that Wang Ji led a punitive expedition of 150,000 soldiers against Mäng ${ }^{2} \mathrm{Maaw}^{2}$ in 1441 (Zhengtong 6). ${ }^{34}$ The phrase "suppresses southern lands from its position" refers to the campaigns that Wang Ji led against the Tai polity of Mäng ${ }^{2} \mathrm{Maaw}^{2}$ that lay south of Yunlong and Tengchong.

Though no extant historical sources mention consanguinity between the Duan native officials of Yunlong and the Duan royal family of the Dali kingdom, the former were closely associated with the swapping of the deities. To understand the connection, we must review the background to the appointment of the Duan as native officials in Yunlong. According to an account titled Yunlong Ji Wang 雲龍記往 written by a native of Yunlong named Dong Shanqing 董善慶, a tribute student (gongsheng 貢生) of 1710, the Tai (Baiyi 擺夷) ethnic group originally exercised power and influence along the Mekong (Lancang) River in Yunlong. ${ }^{35}$ At an unknown point, the Achang 阿昌 replaced the Tai as local leaders and won over the Puman 蒲蠻 people residing there as well. All residents accepted Zao Kai 早慨, a man of the Achang ethnic group, as their leader. Zao Kai's descendants held power for more than ten generations: "They expanded their territory and the population grew, and they traded with the Jinchi (Baoshan) and the Bo Kingdom 本束國 (Dali prefecture)." After another four or five generations of the Zao had passed during the Dali kingdom period, the Duan Emperor sent his men to soothe the Zao. The Zao surrendered and after "receiving the imperial mandate, submitted tribute annually". ${ }^{36}$ The Mongol-Yuan may have appointed the Zao family to serve as the Commander of the Yunlong Dian Military-cum-Civilian Route Command 雲龍甸軍民總管府. Because Zao Bao 早襄, the leader during the latter half of the fourteenth century, was negligent and proved inept at handling political affairs, the Zao appointed two sojourners (kemin 客民), named Li Guanzhang 李貫章 and Duan Bao 段保, to govern on his behalf. Later, Li Guanzhang plotted to usurp the power of his master, and by dishonesty and trickery, he seized Zao Bao's iron seal of office (tieyin 鐵印) and then massacred nearly all the members of his family. Duan Bao fled from Yunlong and rendered meritorious service to the new dynasty by leading forty-plus indigenous men to fight at Dali on the Ming side. After the Ming conquest of western Yunnan, Duan Bao returned to Yunlong to help reinstate the Zao family. However, the indigenous assembly (yizhong 夷眾) elected him as their leader because no Zao survivors could be found. In appreciation for his service, the founding Ming Emperor appointed Duan Bao the Seal-holding Native Sub-prefect of Yunlong 雲龍州掌印土知州. Duan Bao rose to power as the first Native Official of Yunlong in the Ming because of his close association with the Zao family. ${ }^{37}$ 
The Yunlong Ji Wang testifies that the Duan Native Official of Yunlong worshipped Duan Siping 段思平 (938-944), the founder of the Dali kingdom, as the Sanchong deity from $c .1380$. The text reads:

When [Duan] Bao still served [the Achang leader Zao] Bao, the indigenous people were horrified to hear that a dignitary in military uniform mounted on a white horse covered by a yellow canopy was passing through their territory with an entourage of several tens of attendants. Thinking this strange, Zao Bao sent Duan Bao to meet him, and enquire about the purpose of his visit. The dignitary bowed and said, "The emperor of the new regime will govern this land together with you someday in the future." Then, he vanished from sight. ${ }^{38}$

This was the first time Duan Bao encountered the divine dignitary. The second time occurred after his appointment as the Native Official of Yunlong and on the battlefield in 1383 (Hongwu 16) while fighting Pu Yandu 普顏篤, the rebel ensconced at Foguang stockade 佛光寨 near Dali. ${ }^{39}$ Just when the battle was not proceeding in his favour, the dignitary suddenly appeared in military dress with 300-plus surprise attack troops. With their aid, Duan Bao managed to capture Pu Yandu and take the stockade. When questioned regarding his place of residence, the dignitary replied, "I live on Jizu Mountain." The Yunlong Ji Wang recounts the circumstances that led Duan Bao to worship the dignitary on Jizu Mountain and finally adopt him as the protective deity of Yunlong as follows:

When Duan Bao journeyed to Jizu Mountain to visit the dignitary, the local people explained, "The deity of this mountain is Emperor Jizu", so Duan Bao went to worship him. On returning home, he painted an image of Emperor Jizu, and used it as the territorial god of Yunlong (Yunlong tuzhushen 雲龍土主神). ${ }^{40}$ People with illnesses recovered, if they prayed to it. Even now, the local people still worship it. ${ }^{41}$

According to these records, Emperor Jizu helped Duan Bao fulfil his duty to the Ming General Fu Youde and quell the rebellion. The implication is that Duan Bao only managed to capture Foguang stockade with his assistance. Emperor Jizu foretold that Duan Bao would become the future Native Official of Yunlong while he was still serving the Achang leader Zao Bao. Emperor Jizu prophesied that "the emperor of the new regime will govern this land together with you someday in the future". Having enjoyed the protection of Emperor Jizu at critical points in his life, Duan Bao worshipped him as a deity. His journey to search for him on Jizu Mountain can be construed as a pilgrimage. With his deep faith, it was only natural that Duan Bao, as the Native Official of Yunlong, adopted Emperor Jizu as the territorial god of his domain. Emperor Jizu was the first god worshipped as the Sanchong deity and probably had associations with Buddhist beliefs dating back to the Dali kingdom era. The "manifestation of a divine being in Ming times" accorded with the belief in the samsāra, or repeated cycles of birth, misery and death caused by karma. 


\section{Zhao Min}

After the appointment of Duan Bao as the Native Official of Yunlong, the Achang Zao family moved southward and settled in the area around Caojian 漕澗. As in the Wujing salt-producing area and as at Jiuzhou, the residents of Caojian worshipped Sanchong as their territorial god. At Caojian, the Sanchong deity referred to Wang Ji, not Emperor Jizu. The following legend presently circulating among the local people of Caojian provides background on the deification of Wang Ji as the Sanchong deity. The legend commences with the Minister of War drawing up plans to construct a walled city at Tengchong on land overgrown with rattan plants. To obtain labourers to clear the ground, he shaped silver bullion into beads and then threw the beads amidst the rattan. Attracted by the high value of the silver (one bead was equivalent to one silver yuan), the local people eagerly chopped down the rattan to gather the beads. By the time that they had collected all the silver beads, no rattan remained standing. By subsequently burning the chopped rattan, Wang Ji obtained a piece of flatland suitable for constructing a walled city. Before the lunar new year, Wang Ji returned to his native home, leaving his eldest son to supervise the soldiers in the construction of the city. Being kind by nature, the eldest son granted the soldiers a holiday, allowing them to spend the New Year with their families too. On his return, Wang Ji killed his son because he thought that the soldiers would not come back to continue with the city's construction. However, all the soldiers resumed work after the New Year holiday out of fear that Wang Ji would execute them and their families if they did not. After all, the only person Wang Ji killed was his own son. After completing the construction of Tengchong city, the third son of Wang Ji erected a walled city at Caojian. He chose a site at a village known as Rende 仁德 in today's Caojian township. Because subordinates of the third son were evil, the angered local people retaliated by poisoning the food and water wells of Wang Ji, his family and his subordinates. Except for the third son, everyone died instantly. The third son did not, however, probably because he had eaten very little. He eventually died at Wangjiang Slope 望江坡 in Jiuzhou while attempting to report the poisoning to local officials. To commemorate him, a statue was made. This legend holds that Minister of War Wang Ji died after being poisoned by disgruntled local people. ${ }^{42}$

After the Zao migrated to Caojian, they changed their family name to Zuo 左. Descendants of the Zuo of Caojian at Tengchong branched out into two lines: the Zuo of Mingguang 明光左氏 and the Zuo of Cizhu 茨竹左氏. Southern Ming bureaucrats posted Zuo Wenwei 左文偉 to guard Mingguang in 1655 (Yongli 8) to prevent plundering by people known as "wild men (yeren 野人)". His mother Madame Liu 劉氏and more than a hundred families of crossbowmen settled in Mingguang. Later, the Qing appointed Zuo Wenwei Native Company Commander of Mingguang (Tu Qianzong 土千總) in recognition of his meritorious service. The Qing commended his descendant Zuo Daxiong 左大雄 for resisting the British invasion of the Yunnan-Burmese border. For this meritorious service, the Qing conferred on him the title of Hereditary Native Assistant Brigade Commander of Mingguang 明光關世襲土守備. He gained jurisdiction over a larger area than before, his control now extending for more than $210 \mathrm{li}$ and including 
locations such as Dajiang 大江, Xiaojiang 小江, Chashan 茶山, Langsu 浪速 and Lisu 傈傈. ${ }^{43}$ The Qing also rewarded Zuo men from Cizhu for good service to the state. For instance, Zuo Zheng Bang 左正邦 was awarded the title Native Squad Leader of Cizhu village (Cizhuzhai Tu Bazong 茨竹寨土把總) for meritorious service in the campaign against Cheng Jia 秤戛. ${ }^{44}$ In 1747 (Qianlong 11), Zao Ke, a descendant of the original Senior Official at the Chashan Chief's Office (Chashan Zhangguan Si Zhangguan 茶山長官司長官), attacked Pianma 片馬, Yudong 魚洞 and other places to recover land that belonged to his ancestors when the Lisu ethnic group revolted at Chengjia 秤戛. Zuo Zhengbang was appointed hereditary Native Squad Leader for suppressing the Lisu rebellion, and he fought in Yunzhou during the Daoguang era. The Zuo family in Tengchong, who traced their line of descent to the Zuo Native Officials at Caojian, worshipped Wang Ji as the tutelary deity of their land.

The entry on local customs in the Kangxi edition of the Yunlong subprefecture gazetteer identifies the Sanchong deity as a Han General 漢將:

Ailing people sacrifice offerings, swine and sheep to thank their deity. They prepare distilled alcohol and paper ingots. They invite shamans ( $w u$ 巫) who say, "several scented boys dance and sing to amuse the god ... the sacrificial offering and the wine must be tasted before presentation to the god". According to legend, Sanchong was a Han General 漢將 who had been poisoned by indigenous people at Caojian; therefore the sacrificial offerings had to be presented in this way. This deity was extremely efficacious, and people came to give their thanks for answering their wishes every day. ${ }^{45}$

Sanchong worship became highly popular in Yunlong during the Qing dynasty. The Kangxi gazetteer notes that the Han General Sanchong had been "poisoned by indigenous people" and was later transmuted into a local tutelary god. The Guangxu edition of the Yunlong sub-prefecture gazetteer provides a more detailed account of the origin of Sanchong as follows:

The Sanchong Shrine 三崇祠, located on the slope of Delong Mountain 德龍山, was repaired by Gu Fangzong 顧芳宗, the sub-prefecture magistrate. Every year, sacrificial offerings were made in the spring and the autumn. Now, it has been shifted to the left of the sub-prefectural seat (zhoushu 州署). It was destroyed by bandits and rebuilt by the local people in 1875. The origin of the deity is reproduced here: the surname of the Sanchong deity is Wang 王 and his posthumous name was Ji 驥. He fought in the three campaigns against Longchuan 隴川 $\left[\mathrm{Mäng}^{2} \mathrm{Maaw}^{2}\right]$, which was administered by Tengyue 騰越 but was located in today's Longchuan 隴川. In the first lunar month of 1441 (Zhengtong 6), Si Renfa, the Pacification Commissioner (Xuanweishisi 宣慰使司) of Longchuan, revolted and captured Tengchong. [The court] ordered Mu Sheng 沐晟 and Mu Ang to quell the rebellion, but they failed. The next punitive expeditions led by Jiang Gui 蔣貴and Wang Ji ended in victory. [The Emperor] enfeoffed Jiang 
Gui as the Marquis of Pacifying the West 定西侯 and enfeoffed Wang Ji as the Earl of Jingyuan 靖遠伯. During the third lunar month of 1448 (Zhengtong 13), Si Jifa 思機發, the younger brother of Si Renfa, occupied Meng Yang 孟養. He sent tribute but refused to pledge allegiance to the Ming court. So [the Emperor] ordered Wang Ji to take charge of military affairs with the title “General of Pacifying the Barbarians 平蠻將軍”, and he led 150,000 soldiers on a punitive expedition against Si Jifa. The army crossed the Jinsha River 金沙江 [Ayeyarwaddy River] in the spring of the following year and arrived at Guiku Mountain 鬼哭山. Though the army captured more than ten fortified stockades, Si Jifa managed to escape. The army passed through Meng Yang and arrived at Meng Nahai 孟那海, located west of the Jinsha River and over a thousand $l i$ from Longchuan. Si Jifa occupied Meng Yang again. So, assuming that he could not capture Si Jifa after all, Wang Ji erected a stone column (shibiao 石表) at the Jinsha River and made a vow regarding Si Lufa 思陸發 saying: “Only when the stones crumble and the river dries up will you be able to cross." He then gathered his troops and returned. Today, [people] in Tengyue [Tengchong] worship Wang Ji as their deity. ${ }^{46}$

After the sub-prefectural seat of Yunlong shifted from Jiuzhou to Luoma salt well (today’s Baofeng Township 寶豐鎮), a Sanchong temple was constructed at the new location. Subsequently, Sanchong came to be worshipped as the local tutelary deity protecting the Luoma salt well. People in Tengchong also worshipped Wang Ji as the Sanchong god.

\section{Conclusion}

The use of the salt-barter system to maintain the military in western Yunnan combined with the emergency situation created by the war with the Tai polity of Mäng ${ }^{2}$ Maaw $^{2}$ transformed local society. Salt and grain transportation served as catalysts for change. The early Ming state transformed salt, originally a commodity produced within the binary structure of state/state taxation and salt-makers, into a vital link in a complex system to support defence in western Yunnan. The Ming implemented the salt-barter system to feed the Guards and Battalions located in areas both under native official and under direct imperial administration. This arrangement provided the military with grain and local civilians with salt. However, it was founded on the premise that merchants from outside Yunnan would profit from delivering grain to the Guards and Battalions in return for the right to sell salt produced in western Yunnan. Thus, when the war with Mäng ${ }^{2}$ Maaw $^{2}$ adversely affected the exchange rate between salt and grain, making the system unprofitable for merchants, the state had to turn to local magnates and in certain cases to local military officials for grain supplies. State incentives provided to local magnates to encourage them to sell grain ended up creating wealth among magnates and other groups with access to salt at the points of production. The prospect of opportunities in the new political and economic environment at 
the local level attracted migrants. Changed circumstances caused indigenous people to leave Yunlong during the late fourteenth century. The Yunlong Ji Wang describes the circumstances after Duan Hai 段海 succeeded his father Duan Bao as Native Official in 1397 (Hongwu 30) as follows:

At the time, more and more wet fields were opened, and the numbers of merchants from outside (keshang 客商) grew daily. Indigenous people were inept at calculation, and the merchants from outside encroached on their interests, escalating the distress of the indigenous day by day; some died, and some moved out. The merchants from outside grew numerous, while the numbers of indigenous people gradually shrank. ${ }^{47}$

The proliferation of migrant merchants changed the ethnic composition of the local population. The new social environment created by the Ming state played a part in transforming local society in Yunlong during the late fourteenth century. The intricate interconnection between the state, merchants and native officials transformed the delivery of grain for the military and the sale of local salt into catalysts for change in western Yunnan local society.

The substitution of new gods for old in Yunlong and Tengchong illustrates how the early Ming state triggered a transformation in local religious beliefs. The replacement of the Dali kingdom deity Emperor Jizu, the original tutelary god of Yunlong, with the Ming official Wang Ji in Sanchong temples represented a substantial departure from past tradition. Emperor Jizu symbolised strong connections with the Dali kingdom that survived through Mongol-Yuan times. However, Wang Ji, as Minister of War and Regional Military Commander of Yunnan 雲南總兵官, represented the conquering Ming dynasty. A series of mergers and mixings occurred, and although the name Sanchong remained the same, the identity of the deity worshipped changed. This transmutation of divine identity testifies to the incorporation of Yunnan into Ming territory. Before 1382, most Chinese regarded Yunnan as an alien land inhabited by barbarians. However, the Ming displaced the boundary with the barbarians to more distant lands in Southeast Asia. In the Ming punitive campaigns against “indigenous rebellions" (yiluan 夷亂), local magnates displayed no empathy towards indigenous people. Instead, these magnates co-operated enthusiastically with the Ming, competing with rotating officials for official positions and emoluments. The strategy of using military campaigns to complement the tribute system in controlling ethnic groups in borders areas exerted a far-reaching effect on the history of Yunnan during the Ming period.

\section{Notes}

1 Fan Ye, Hou Han Shu, p. 2851.

2 Pan Chuo, Manshu, juan 7, p. 189.

3 Taizu Shilu, p. 2240.

4 Taizu Shilu, pp. 2240-2241. 
5 Zhang Tingyu, Mingshi, p. 1931.

6 Zhang Tingyu, Mingshi, p. 1935.

7 Taizu Shilu, pp. 2258-2259.

8 Taizu Shilu, p. 2370.

9 Zhang Tingyu, Mingshi, p. 1934.

10 Xuanzong Shilu, p. 732.

11 Xuanzong Shilu, p. 1793.

12 Zhang Tingyu, Mingshi, pp. 8116-8117.

13 The memorial was submitted in the second lunar month of 1439; see Yingzong Shilu, p. 362.

14 Zhang Tingyu, Mingshi, p. 130.

15 Yingzong Shilu, p. 1068.

16 Yingzong Shilu, pp. 1160-1161.

17 Yingzong Shilu, pp. 3455-3456.

18 Yingzong Shilu, p. 1000.

19 Yingzong Shilu, p. 1090.

20 Yingzong Shilu, pp. 5432-5433.

21 Yingzong Shilu, p. 4348.

22 Yang Nanjin 楊南金, “Dengchuan zhou Tuguan Zhizhou A Shi Wushi Mubiao 鄧川 州土官知州阿氏五世墓表”, in Yang Shiyu and Zhang Shufang, Eds. (1993), Vol. 10, p. 71.

23 “Longmen Yi Shixing Sixi Canbei 龍門邑施姓世系殘碑碑》” in Yang Shiyu and Zhang Shufang, Eds. (1993), Vol. 2, p. 110.

24 He Mengchun, “Qing Fuzhi Yongchang Fuzhi Shu 請復置永昌府治疏”, in Fang Guoyu, Ed. (1998), p. 644.

25 Li Yuanyang, Wanli Yunnan Tongzhi, juan 3, 4a-4b.

26 Li Siquan and Huang Yuanzhi, Eds., 1694 Dali Fuzhi, 12:7a-7b; 142. The original has 文物 for wenwu. I have corrected it to 文武.

27 Xuanzong Shilu, pp. 204-205.

28 Xuanzong Shilu, p. 1769.

29 Yingzong Shilu, p. 58.

30 Zhang Tingyu, Mingshi, p. 7981.

31 Ming Huiyao 明會要, p. 770. Mao Qiling 毛奇齡:

In the early years of Hongwu period, [the Emperor] conferred the official titles already held on the barbarians from the southwest who came to pledge allegiance, and investigated the troops, land taxes and conscript services, military guard and defence systems of the native officials.

See Mao Qiling 毛奇齡, Mansi Hezhi 蠻司合志, juan 1, 2a in Mao Qiling, Mao Xihe Xiansheng Jingji.

32 Li Yuanyang. Wanli Yunnan Tongzhi, juan 12, $10 \mathrm{~b}$.

33 Taishang Shuo Sanchong Jing 太上說三崇經, p. 9. The original text of the citation is as follows:

崇山勝景, 雞足靈峰. 唐代出生, 能以孤忠開國運, 明時顯聖, 恒將至德裕民 生, 與物為春澤沛, 彌災歡眾志. 代天宣化, 扶良除暴洽輿情. 功標北閣, 位鎮南 邦. 大悲大愿, 大聖大慈, 敕封三崇建國雞足佑民皇帝.

34 Zhang Tingyu, Mingshi, p. 8117.

35 The text of the Yunlong Ji Wang 雲龍記往 is included in Wang Song, Ed., Yunnan Beizhengzhi, pp. 1055-1065. According to the introduction to this text, a Qing man Wang Fengwen 王鳳文 revised and re-arranged Dong Shanqing's original text into four juan. This text traces the history of the Duan Native Official in Yunlong from Duan Bao until 1707 (Kangxi 46).

36 Wang Song, Ed., Yunnan Beizhengzhi, pp. 1059-1061.

37 Wang Song, Ed., Yunnan Beizhengzhi, pp. 1059-1062. 
38 Wang Song, Ed., Yunnan Beizhengzhi, p. 1062.

39 Foguang stockade lay on the boundary between Eryuan and Heqing counties. Duan Bao led 1,000 indigenous troops to fight against $\mathrm{Pu}$ Yandu, and the Ming army conquered Foguang stockade during the seventh lunar month of 1383.

40 Tuzhu literally means "master of a certain territory". Such territorial gods were very popular in the Dali area and remain so even today.

41 Wang Song, Ed., Yunnan Beizhengzhi, pp. 1062-1063.

42 He Jianhua 何建華 (age 71) recounted the legend to me in July 2016. A Bai 白person and a native of Caojian Township, He Jianhua was the caretaker of the Sanchong temple 三崇廟 in Caojian at the time.

43 Zuo Daxiong 左大雄, “Mingji Gaofeng Shishou Caojian Wujie Jiangjun Muzhi Ming 明季誥封世守漕澗武節將軍墓志銘”, in Yunlong Wenshi Ziliao, Vol. 1, p. 64.

44 Wang Song, Daoguang Yunnan Zhichao, p. 362. In addition, Zuo Zhengbang was awarded a Pacification Commission (Xuanfu Si 宣撫司) title for suppressing a Lisu 傈僳 rebellion in Diantan Shangjiang 滇灘上江 during the Daoguang era and for fighting at Yunzhou 雲州 (today's Yun county in Lincang); see the Tusi kao 土司考 in the Xinzuan Yunnan Tongzhi 新纂雲南通, p. 687.

45 Kangxi Yunlong Zhouzhi, 康熙雲龍州志, juan 5 Fengsu, p. 5.

46 Zhang Dexu et al., Revised., Yang Wenkui, Ed., Guangxu Yunlong Zhouzhi. Cisi 祠 祀, no pagination.

47 Wang Song, Ed., Yunnan Beizhengzhi, pp. 1063.

\section{Bibliography}

Fan Ye 范瞱. Hou Han Shu 後漢書. Beijing: Zhonghua Shuju, 1985.

Fang Guoyu, Ed. Yunnan Shiliao Congkan 雲南史料叢刊. Kunming: Yunnan Daxue Chubanshe, 1998.

Kangxi Yunlong Zhouzhi, 康熙雲龍州志. In the collection of Harvard University.

Li Siquan 李斯佺 and Huang Yuanzhi 黄元治, Eds. 1694 Dali Fuzhi 康熙 大理府志. Beijing: Shumu Wenxian Chubanshe, 1988.

Li Yuanyang 李元陽, Ed. 1573 Wanli Yunnan Tongzhi 萬曆雲南通志. Beijing: Zhongguo Wenlian Chubanshe, 2011.

Mao Qiling 毛奇齡. Mao Xihe Xiansheng Jingji 毛西河先生經集. Preface of 1796 (Jiaqing 1). Printed at the Chengdong Shuyuan 城東書院 in Xiaoshan 蕭山. Held by the Toyo Bunko, Tokyo, Japan.

Ming Huiyao 明會要. Taibei: Shijie Shuju, 1972.

Pan Chuo 攀綽. Manshu 蠻書. Taibei: Dingwen Shuju, 1972. (楊家駱主編 國學名著珍 本彙刊 史學彙刊之一).

Taishang Shuo Sanchong Jing 太上說三崇經. A facsimile of a hand-copy made in 1936 held by Mr. Yang Sen 楊森 in Xingling village 杏林村 in Yunlong county.

Taizu Shilu 太祖實錄. Taibei: Guoli Zhongyang Yanjiuyuan Lishi Yuyan Yanjiusuo, 1962.

Wang Song 王崧. Daoguang Yunnan Zhichao 雲南志鈔. Kunming: Yunnan Sheng Shehui Kexueyuan Wenxian Yanjiusuo Dianxiaoben 雲南省社會科學院文獻研究所 點校本, 1995.

Wang Song 王崧, Ed. Yunnan Beizhengzhi 雲南備徵志. Kunming: Yunnan Renmin Chubanshe, 2010.

Xinzuan Yunnan Tongzhi 新纂雲南通志. Kunming: Yunnan Renmin Chubanshe, 2007.

Xuanzong Shilu 宣宗實錄. Taibei: Guoli Zhongyang Yanjiuyuan Lishi Yuyan Yanjiusuo, 1962. 


\section{Zhao Min}

Yang Shiyu 楊世鈺 and Zhang Shufang 張樹芳, Eds. Dali Congshu Jinshi Pian 大理叢 書金石篇. Beijing: Zhongguo Shehui Kexue Chubanshe, 1993. 10 volumes.

Yingzong Shilu 英宗實錄. Taibei: Guoli Zhongyang Yanjiuyuan Lishi Yuyan Yanjiusuo, 1962.

Yunlong Wenshi Ziliao 雲龍文史資料. Place of publication unknown: Yunlong County Zhengxie, 1986, Vol. 1.

Zhang Dexu 張德需 et al. Revised, Yang Wenkui 楊文奎, Ed. Guangxu Yunlong Zhouzhi 光緒雲龍州志. Hand-copy edition in the collection of the Yunlong Xianzhiban 雲龍縣 志辦.

Zhang Tingyu 張廷玉. Mingshi 明史. Beijing: Zhonghua Shuju, 1974. 


\title{
2 Local communities, village temples and the reconstruction of ethnic groups in western Yunnan, fourteenth to seventeenth centuries
}

\author{
Jianxiong $M a^{1}$
}

\section{Introduction}

This chapter investigates how shifts in Ming state administration, particularly household registration, taxation and systems for social control, shaped the transformation of local society in the three basins of Dengchuan 鄧川, Fengyu 鳳羽 and Langqiong 浪容 near Dali between the fourteenth and eighteenth centuries. Lying directly north of Lake Erhai, the core area of the Nanzhao and the Dali kingdoms, these three basins fall under the jurisdiction of today's Eryuan county 洱源縣 2 and are watered by tributaries of the Miju River 瀰苴河. Focusing on irrigation facilities, I trace the construction of different categories of local community through household registration and other administrative policies in the early Ming, their decline during the late Ming/early Qing, and their reconstruction as new communities during the seventeenth and eighteenth centuries through the agency of the local elite. I argue that the increase in village-owned common property and the joint management of water resources for wet rice agriculture shaped social change in the village communities in the basins from the seventeenth century.

To orientate readers to this long chapter, I briefly elucidate the significance of the local elite. The local elite that promoted transformation in the societies of the three basins consisted of gentry (i.e., degree holders), literati and village leaders. During the late fifteenth and sixteenth centuries, the gentry and literati advocated the reform of customs and practices to adjust local society to conform to empire-wide Ming norms. After the seventeenth century, they gained control of water management together with village leaders, which endowed them with the authority to re-interpret and reform culture, customs and ritual performance in their communities. The local elite orchestrated the establishment of common property to generate income to operate small-scale irrigation systems from the late Ming and gradually came to manage common resources in communities. I argue that it was the need to manage common property that provided this local elite the socio-political space and flexibility it required to respond effectively to changes in state policy and institutional shifts. The ability of the local elite to alter the cultural identity of local communities aided 
the integration of diverse social categories defined by the Ming state into new communities centred on village temples. In this reconstruction process, the village temple system played an important role because it became a centre for devising strategies for the local communities to address changes in state policies. In the new communities, the principle of sharing resources became a characteristic feature. In fact, it was the sharing of resources that differentiated communities in the three basins of Eryuan county from those on the eastern littoral of South China, where villages were organised on the basis of lineage or same surnames. ${ }^{3}$

As background to the analysis of the long-term changes between the fourteenth and eighteenth centuries, this chapter begins by explaining the reasons why wet rice cultivation required communities in the basins of western Yunnan to devise systems for the management of labour and water resources. Subsequently, the chapter offers a historical overview of the state administration of the three basins of Dengchuan, Fengyu and Langqiong.

\section{Wet rice cultivation and basin societies}

Uplands occupy approximately 94 per cent of the Yun-Gui plateau of Southwest China and the highlands of northern Shan State in Burma. Flatlands in valley basins only occupy approximately 6 per cent of this area. ${ }^{4}$ In the basins of Eryuan county, flatlands occupy 335 square km, 11 per cent of the total area of the county. ${ }^{5}$ The county has numerous lakes, springs, reservoirs and swamps as well as small and large rivers. Abundant land and water resources as well as a climate with a distinct division between rainy and dry months makes the basins of Eryuan county suitable for wet rice cultivation. All rivers run towards Erhai Lake, from which they flow into the Mekong River. The tributaries of the Miju River provide most of the water for wet rice irrigation in the three basins and serve as the main water source for the lake. ${ }^{6}$ Basins at elevations ranging from 2,000 to 2,200 metres above sea level occupy 11 per cent of the land in Eryuan county. ${ }^{7}$ Seventy-four per cent of the county's farming land lies in the irrigated basins of Dengchuan (shown in Figure 2.1), Fengyu and Langqiong, where 80 per cent of the county's population resides. ${ }^{8}$ The present population density ratio between basins and uplands in Eryuan county is 10:1. ${ }^{9}$ Wet rice cultivation is a feature that distinguishes basin communities from upland ones. Because wet rice cultivation required social co-operation and could support relatively large populations, basins became political and market centres and functioned as transportation networks between western Yunnan, the Tibetan Plateau and Burma. ${ }^{10}$

The success of wet rice cultivation depended on a combination of environmental and social factors. Climate in the Yunnan basins is characterised by a clear distinction between dry and wet seasons: the dry season lasts from November to April and the wet season from May to October. Rainfall from May to October accounts for more than 90 per cent of annual precipitation. ${ }^{11}$ Because rice seedlings had to be transplanted between the Xiaoman 小滿 and Mangzhong 芒種 


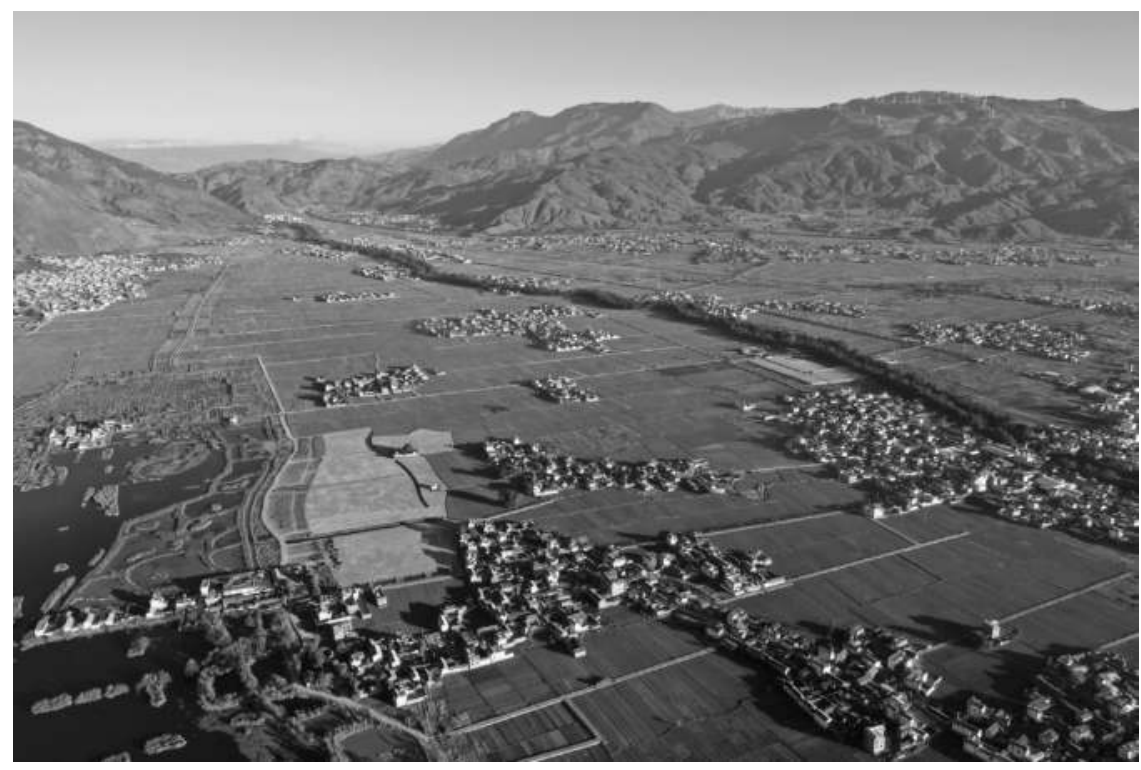

Figure 2.1 Villages in the Dengchuan basin located along the banks of the Miju River 瀰苴河 (the line of trees in the centre).

From this basin the river empties into Lake Erhai, a part of which is visible at the front left.

Aerial photograph: Li Shiyang 李仕陽, 2019.

solar terms (between approximately 21 May and 5 June), this climatic characteristic shaped the social mechanism for labour exchange and water sharing. If the monsoon rain began falling after approximately 6 June, subsequent water shortages would affect the harvest. After the rice harvest in the autumn, wheat, fava beans and rapeseed were planted in the dry season without irrigation. The securing of sufficient water to transplant rice seedlings before the monsoon rains arrived in May/June was essential for prolonging the growth period of rice at this high altitude. To safeguard their crops against the irregularities of monsoon rain and guarantee good harvests, all cultivators required irrigation to transplant their seedlings, and they had to share labour and distribute water to complete ploughing, add manure and transplant seedlings within this critical month. Therefore, community families had to co-operate to organise labour to ensure that all cultivators finished transplanting before early June. Thus, wet rice cultivation created a need for intracommunity and inter-community co-operation, and this feature became characteristic of the basin societies of western Yunnan.

The management of large-scale irrigation systems on main rivers, such as the Miju and its tributaries, largely remained under the control of county magistrates. However, many irrigation systems in the three basins were small in scale, only collecting water from minor streams and distributing it to a limited number 
of communities by canal. The small-scale irrigation systems in the Dengchuan, Fengyu and Langqiong basins were distinguished by management of labour and water at the community level. This chapter does not address the large-scale irrigation projects controlled by bureaucrats. Rather, it focuses on these small-scale projects. Particular attention is paid to the role of the local elite, particularly the gentry, in the management of issues related to water, agricultural resources and negotiating with the state. County magistrates issued regulations and orders that supported the local elite from the early Qing dynasty onward. Therefore, I utilise stele inscriptions, local gazetteers and official documents as well as notes from my own fieldwork as sources.

The increase in basin populations in western Yunnan due to the expansion of wet rice cultivation resulted in a seasonal shift in labour. Young males took advantage of the dry season after the rice harvest to work as traders in long-distance mule caravans or as craftsmen in upper Burma and Tai-speaking areas on the borderlands between Yunnan and Burma. Often travelling in groups, some of these young men worked as muleteers, other as miners in the uplands, as builders for native officials (tuguan 土官/tusi 土司), or as itinerant carpenters, masons and blacksmiths moving from one village to the next. Yet others found employment as short-term labourers. ${ }^{12}$ Different ecological environments required diverse styles of labour co-operation and communal organisation in the basins and uplands of western Yunnan. The dry season in the cycle of wet rice cultivation provided villagers who possessed knowledge and skills an opportunity to earn income by working in communities of diverse ethnicity and culture spread across parts of southwestern Yunnan and northern mainland Southeast Asia. In this way, the movement of seasonal labour extended social connections from a single basin to a larger geographical area through transportation systems and the circulation of goods. ${ }^{13}$

\section{Historical overview of irrigation in the three basins}

Historical sources reveal that Dengchuan, Fengyu and Langqiong came under the administration of the Nanzhao kingdom from the eighth century. Nanzhao placed them under Langqiong 浪穹州, which was established in 794. After the defeat of the Dali kingdom in 1253/54, the Mongol-Yuan divided Langqiong prefecture into two Battalions 千户, which were subordinate to the Dali Circuit 路. With the founding of Dengchuan prefecture in 1274, the Mongol-Yuan renamed the two Battalions Fengyu county and Langqiong county. In 1383, after the Ming army finally suppressed the local resistance based at Foguang stockade 佛光寨, which lay between Langqiong and Heqing 鶴慶, the Ming appointed a Tai (Baiyi 擺夷) leader named A Zhe 阿這 hereditary Native Official in charge of Dengchuan. By this appointment, the Ming rewarded A Zhe for his meritorious service in leading troops from his native Weiyuan sub-prefecture in south Yunnan to aid the Ming army in the conquest of Dali. In its capacity as hereditary Native Officials, the A family subsequently played a crucial role for centuries in administrating the upland areas surrounding each of the three basins. 
When the Ming established Dengchuan county in 1569, they retained the A family to help regular bureaucrats (liuguan 流官) govern under an arrangement known as "joint administration by native officials and regular bureaucrats" (tuliu jianzhi 土流兼治). The Ming apportioned part of western Langqiong county to neighbouring Yunnan county in 1620, decreasing the significance of Fengyu basin as a transportation link to the salt wells in Yunlong. After the 1911 Revolution, the Yunnan provincial government renamed Langqiong as Eryuan county. However, Dengchuan county remained until 1958, when the PRC merged the two counties into the new Eryuan county. ${ }^{14}$

The three basins and their surrounding uplands underwent social and political change between the ninth and thirteenth centuries, when the capital of Yunnan was located at Dali. Wet rice agriculture yielded rich harvests to support relatively dense populations in the villages and market towns in these basins. Two key factors shaped the social transition in Langqiong and Dengchuan Counties after the thirteenth century. The first was a change in state administrative institutions. The second was a shift in social and economic relations. The change in administrative institutions encompassed the establishment of counties, military Guards, the appointment of native officials during the early Ming, and the subsequent abolition of Guards and military households during the late Ming/early Qing. The accompanying shifts in administrative units and state policies caused alterations to household registration, identity reconstruction, and adjustments to agricultural landholdings and the management of water resources. Together, this set of changes resulted in the reconstruction of basin societies as communities structurally adapted to the ecology of basins and irrigated wet rice agriculture. Ethnic identities and social relationships were defined and redefined as new communities emerged.

By establishing Guards (wei 衛) and Battalions (suo 所), the Ming permanently settled Han military personnel and their families in the basins of Yunnan, requiring them to raise their own grain by cultivating land on state farms. Although originally designed for defence and to maintain social stability, military settlement played a crucial role in stimulating the reconstruction of basin communities. The Ming registered Guard troops as hereditary military households ( junhu 軍戶), ${ }^{15}$ thereby clearly distinguishing them from civilian households (minhu 民户). In accordance with the requirements of lijia (里甲) household registration, Ming bureaucrats organised civilian families in Langqiong county into $25 l i$ in the early period and added another $7 \mathrm{li}$ when they extended lijia registration to the Fengyu basin during the Wanli reign period (1573-1620). Registration of civilians into $l i$ 里, or units of 110 households, functioned as an organisation for tax collection and as a system for controlling the rural population by creating a stable base for peasant reproduction. ${ }^{16}$ In Dengchuan county, the Ming enumerated the population into $12 \mathrm{li}$ but left the population of the northern upland area registered as Yangtang $L i$ 羊塘里 under the control of the A Native Official family. Military personnel and their families were not organised into $l i$ and jia units during the early and mid-Ming. However, from the Wanli reign period, all military households in Dengchuan county were organised into lijia units for the 
purpose of collecting taxes and assigning labour service in accordance with a policy known as "integrating Guards into [independent] sub-prefectures" (caiwei guishou 裁衛歸州). This reform expanded the total number of $l i$ in the county from 12 to $14 .{ }^{17}$ Langqiong county underwent reforms similar to those in Dengchuan during the late Ming, and the organisation of all military households in Langqiong county into the lijia system and the re-measurement of agricultural land was completed by $1670 .{ }^{18}$ Population growth resulted in deforestation in the uplands as mountain land was cleared for cultivation. These ecological changes caused the tributaries of the Miju River to flood increasingly larger areas of agricultural land in the basins. As a result, the effective operation of irrigation projects, particularly the construction, repair and maintenance of river dikes to protect villages and farming land, became a pressing issue in the Dengchuan basin. ${ }^{19}$ Bureaucrats mobilised both civilian and military households to manage water resources along the Miju River in the Dengchuan basin near Erhai Lake from the early Ming. All civilian households registered in the $11 \mathrm{li}$ had to provide one person for labour service on the river dikes in winter for every dan (石) of grain (approximately $60 \mathrm{~kg}$ ) they paid to the state as taxation. Military households were divided into units of three households, with each unit being required to provide two individuals to work on the irrigation facilities. The workers, who could be male or female, gathered after the Spring Festival to reconstruct the river dikes and dredge the Miju River. The worker teams were led by village heads in the case of civilians and military officers in the case of the Battalions, and county bureaucrats oversaw all the projects. ${ }^{20}$

When the dikes of the Miju River collapsed in 1622 (Tianqi 2), bureaucrats fined all the villages that had neglected their maintenance duties. The Dengchuan County Magistrate bought $300 \mathrm{mu}$ of farming land (approximately 20 acres) with the money from the fines and allocated the income earned from the rent of these lands to cover the expenses of repairing the dikes. County bureaucrats continued to enlarge funds for river maintenance by purchasing more income-earning land right up until 1949. Eventually, the acreage of agricultural land rented to provide funds for river repairs totalled approximately 1,500 $\mathrm{mu}$ (approximately 100 acres), yielding a total income of more than 10,000 silver dollars. ${ }^{21}$ Apart from managing the Miju River, local gentry also implemented other hydraulic projects. Gao Shanggui, a native of Yinqiao village 銀橋村 in Dengchuan county, who had served as the Magistrate of Chaling 茶陵 in Hunan province, donated his salary to mobilise village gentry to dig a new canal on the western side of Dengchuan basin, known as the Yong'an River (永安江), in 1781 (Qianlong 46). The construction project required 26 months, 60,000 labourers and 3,600 liang silver (approximately $13.32 \mathrm{~kg}$ ) to complete, and the new canal saved 11,200 mu (approximately 746 acres) of farmland from inundation. $^{22}$ As mentioned earlier, the management of large rivers, such as the Miju and its main tributaries, largely remained under the control of county magistrates. However, local gentry managed irrigation canals and small rivers on the basis of regulations issued by county magistrates from the early Qing dynasty onward. 


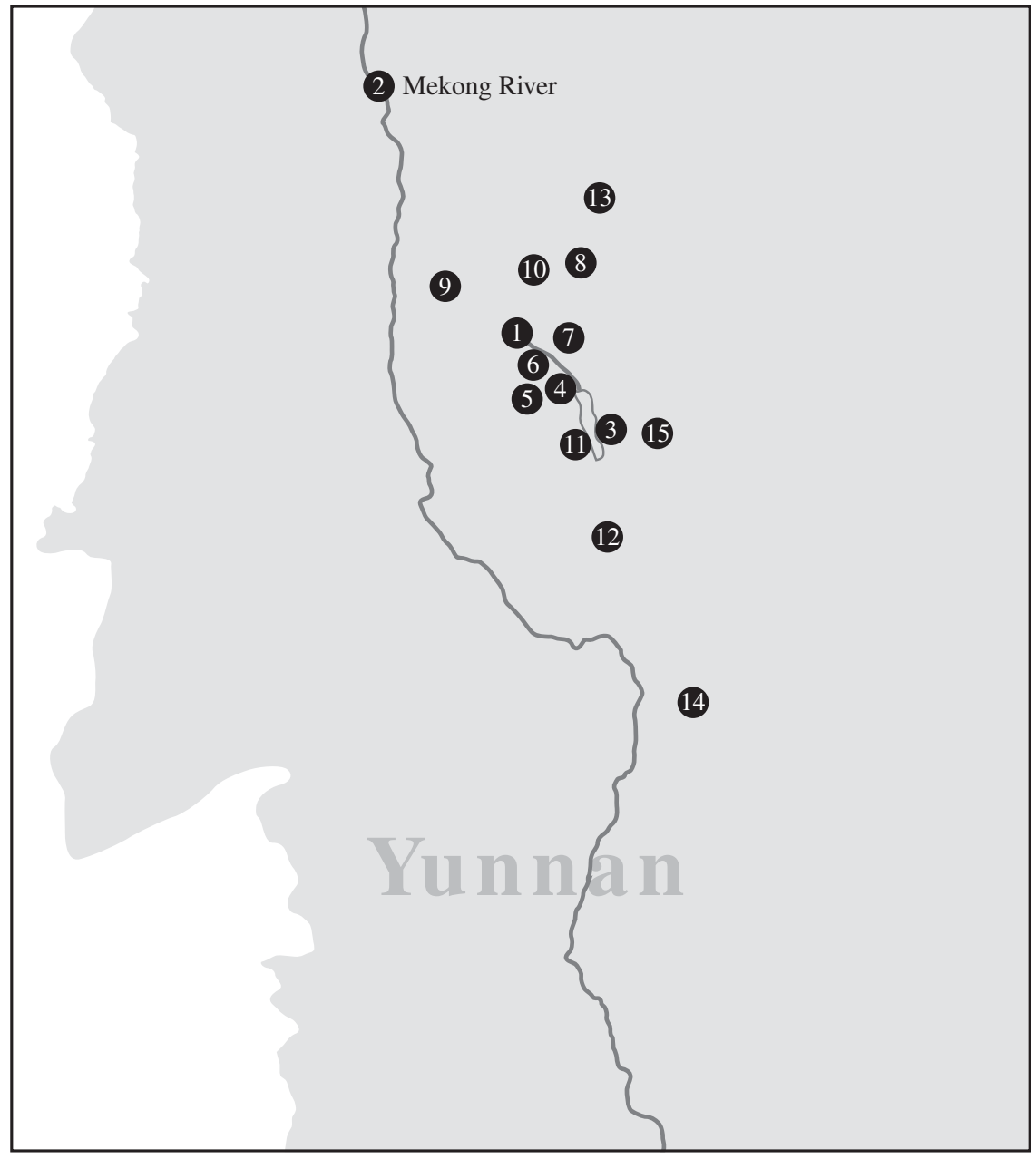

(1) Miju River 洅苴河

(7) Foguang Stockade 佛光寨 13 Lijiang 麗江

(2) Mekong River 瀾滄江

8 Heqing 鶴慶

14 Jingdong 景東

(3) Lake Erhai

9) Lanzhou 蘭州

15 Binchuan 賓川

(4) Dengchuan 鄧川

10 Jianchuan 劍川

(5) Fengyu 鳳羽

(11) Dali 大理

6 Langqiong 浪穹

(12) Menghua 蒙化

Map 2.1 Dali region, c. 1582. 


\section{Institutional changes and the differentiation of social identities}

The Mongol-Yuan administered local society in Yunnan through the magnate families of the fallen Dali kingdom after the conquest of 1253/54. By appointing the male head of the royal family the Duan Family General Administrator (Duan shi zongguan 段氏總管) after dethroning the King, the Mongol-Yuan perpetuated the authority of the Duan family and other powerful Dali kingdom families, such as the Gao 高 and the Dong 董, throughout the Mongol-Yuan period. The tomb inscription for Gao Laoguan 高老官 (Gao Guanyinlu 高觀音祿) from Eryuan county dated 1479 (Chenghua 15) characterises the pre-Ming as a period in which “the Gao served as leaders, and the Duan served as rulers” ““高家做酋, 段家做詔”). ${ }^{23}$ This inscription reveals that even in the latter half of the fifteenth century, nearly 100 years after the Ming had eliminated the Duan and all vestiges of the Dali kingdom, the local people still understood the socio-political framework of the Dali kingdom as continuing on throughout the Mongol-Yuan period. The inscription traces the pedigree of Gao Laoguan to a Prime Minister of the Dali kingdom named Gao Taiming 高泰明, who was the grandson of Gao Zhisheng 高智升, the latter having gained power after 1073 when the King Duan Silian 段思廉 relinquished power and became a monk, and the Dali kingdom court fell under the Prime Minister's control. ${ }^{24}$ Gao Taiming's grandson, Gao Hai 高海, married a woman from the Zhao family of Fengyu, who gave birth to Gao Laoguan. According to the inscription, Gao Laoguan's wife, Madame Li 李姓, observed the “three obediences and four virtues 三從四德, and her son Gao Xuan displayed filial piety in caring for his mother" and had "completely mastered the [philosophies of] the Various Masters and the Hundred Schools (zhuzi baijia 諸子百家)". ${ }^{25}$ Even though the Gao and Duan families no longer exercised political power, the Gao retained political influence in local communities during the fifteenth century through Buddhist monasteries; as devout Buddhists, the Gao had constructed many temples in the past. The attitude articulated by descendants of the Gao family in this inscription reveals consanguinity with Dali kingdom/Mongol-Yuan period society even as late as 1479 .

Local society gradually changed during the new political environment of the early and mid-Ming. When the Ming established the Guard at Langqiong county (shown on Map 2.1), it settled military personnel in villages in the eastern part of the Langqiong basin. These military households 軍戶 shared the wet rice fields in the basin with the indigenous inhabitants, whom the Ming registered as civilian households. ${ }^{26}$ Ai Zixiu 艾自修 (metropolitan degree 進士 holder of 1600), a scholar-official from Dengchuan, divided military households into two categories: sheren 舍人 and military people (junren 軍人). He wrote as follows:

Sheren are the family members and the kin relatives of commanders of the guard, the battalions and platoon commanders (zongqi 總旗). They provide conscript service (chaiyi 差役) to the guard and pay land tax to [regular bureaucrats]. All have been subordinate to the sub-prefectural magistrate since the Wanli reign period (1573-1619) because they live on Dengchuan 
soil, and eat from [the harvests of] Dengchuan wet fields. Military people are divided into four battalions; thirty per cent of them remain on active service, seventy per cent of them pay land tax, and auxiliary males (餘丁 yuding [family members supporting regular servicemen]) pay their labour services in silver (yinchai 銀差 [i.e., their labour services have been commuted to silver]). Military people on service mostly shoulder the responsibility [for defence] with Native official armies (tujun 土軍); all reside at the borders of the sub-prefecture, and all are subordinate to the sub-prefecture magistrate. This also began during the Wanli reign period. ${ }^{27}$

In 1853, the County Magistrate Hou Yunqin 侯允钦 observed that the guard and battalion system of the Ming functioned on the premise of 70 per cent of the military households cultivating military state farm land and 30 per cent participating in training and defence. Dividing three military households into single working units, the Ming allocated each unit $20 \mathrm{mu}$ of arable land (approximately 3.3 acres) and required them to deliver 50 dan (approximately 2,500 kg) of harvested grain to granaries at the Guard annually. However, after deducting their own grain rations, the actual amount delivered only totalled 22.8 dan (approximately $1,140 \mathrm{~kg}$ ), a figure significantly lower than the target. Later, the Ming changed the regulations, requiring each working unit to deliver 9.12 dan $(456 \mathrm{~kg})$ of rice to the Guard granary. In addition to the military state farms, manors (xunzhuang 勳莊) directly controlled by the Mu family 沐氏, the Imperial Duke, were located in Langqiong and Dengchuan. The Mu family paid no taxes and provided no labour service for holding these manors due to their rank and position. The people on the manors were fierce and uncontrollable and antagonised local bureaucrats until 1685, when the early Qing state placed military households under the jurisdiction of the counties. ${ }^{28}$

Native officials constituted a separate institutional category from that of regular bureaucrats. As mentioned earlier, the Tai leader Dao Ai 刀哀 from Weiyuan sub-prefecture in southern Yunnan fought on the Ming side against the pro-Mongol-Yuan forces resisting at Foguang stockade 佛光寨. According to a tomb inscription of 1508 (Zhengde 3), the Ming appointed A Zhe 阿這, the son of Dao Ai, as the Native Magistrate of Dengchuan sub-prefecture sometime after defeating the resistance in 1383, and he established a seat of office, registered households and established schools. This Tai family changed its surname to A 阿氏 and intermarried with other native officials in western Yunnan. It intermarried with the Zuo 左氏 family of Menghua 蒙化, the Mu 木氏 family of Lijiang, the Tao 陶氏 family of Jingdong 景東, the Luo 羅氏 family of Lanzhou 蘭州 (today's 蘭坪), and established marriage ties with commanders of the Dali Guard 大理衛指揮使. ${ }^{29}$ The A Family Native Official administered the ten Police Offices 巡檢司 established to manage upland communities and salt wells lying between Dengchuan sub-prefecture and valleys along the Mekong (Lancang) River to the west. Only the A family had the authority to command the troops of these hereditary Police Offices. ${ }^{30}$ The Tai soldiers who came with Dao Ai from Weiyuan sub-prefecture settled in Luochuan 羅川, a small basin 
northwest of Dengchuan, and their descendants served as troops for the A family. In 1573, Yuefeng 岳鳳, the adopted son of Duo Shining 多士寧, the Tai Native Official of Longchuan 隴川 on the Sino-Burmese border, murdered Duo, usurped power and proclaimed himself ruler of the domain. Yuefeng later swore loyalty to the Tounggoo dynasty and launched military attacks on native officials in Ming territory. ${ }^{31} \mathrm{~A} \mathrm{Yu}$ 阿鈺, the incumbent Native Official of Dengchuan, was married to the daughter of Duo Shining 多士寧 and therefore participated in the Ming campaign led by Liu Ting 劉綎 and Deng Zilong 鄧子龍 against the invading army of the Tounggoo King Nan-da bayin 莽應里 (reigned 1581 to 1591 ) in $1583 .{ }^{32}$ Due to long-term intermarriage connections with Tai native officials on the Sino-Burmese border, the A family played a role in Sino-Burmese relations. Although it no longer held the title of Native Official in the eighteenth century, the A family aided the Qing during the war between the Qing and the Konbaung dynasty in the 1765-1769 period. This war resulted in another wave of Tai refugee immigrants from the Sino-Burmese border area, who settled as wet rice cultivators at Yangtang $\mathrm{Li}$ 羊塘里 in the Luochuan basin.

In Langqiong and Dengchuan, the three institutional categories of the military (Guards and Battalions), regular bureaucrats and native officials existed in parallel from the Ming to the early Qing. On the one hand, reforms of household registration and tax revenue along with the integration of military families into local society and the abolition of native official titles changed relationships among communities. On the other hand, the A family of Dengchuan played a role in frontier politics, particularly with respect to Burma, and in relations between native officials within Yunnan. These reforms and socio-political changes altered the environment that shaped the cultural and the social identities of literati. Literati strategies and interpretations of culture and identity were strongly influenced by political shifts from the late Ming to the early Qing. A good example can be found in the detailed description of the social categories of identities in late Ming Dengchuan recorded by the scholar-official Ai Zixiu 艾 自修 and published in his compilation the 1646 Gazetteer of Dengchuan Subprefecture 邆川州志. Ai Zixiu, from a military family in Dengchuan, held the position of Sub-prefectural Magistrate of Chenzhou (辰州) in Hunan. After retirement, he returned to Dengchuan, where he educated many students. As a member of the local gentry, he was active as a leader of the local community. His prestige largely derived from his social activities and from the sale of $40 \mathrm{mu}$ of his own wet field land to cover the printing costs of the 1646 gazetteer, an act the Neo-Confucian literati regarded as particularly praiseworthy. Members of the gentry with opinions similar to those of Ai Zixiu emerged during this period as the gentry were rising as a powerful group in local society.

Ai Zixiu classified local society into seven groups, each of which represented different identities: indigenous people 土人, Han people 漢人, guest migrant people 客人, sheren 舍人, military people 軍人, Cuan people 婯人 (here referring to the Luoluo 猓玀 or Yi 彝) and Bo people 來人 (here referring to the Tai). Based on his study of past literature, Ai Zixiu explained the Han people as originating in the descendants of immigrants dating back to the time when Zhu Geliang 諸葛亮 
(181-234), the renowned strategist of the Shu kingdom, led punitive expeditions from Sichuan to Yunnan during the Three Kingdoms period. Han people from the central plains continued to immigrate, and indigenous people named them Han people 漢人. The category of guest migrant people encompassed the descendants of non-military immigrants from the provinces of Zhejiang, Sichuan and Huguang, who came for the purpose of trade or to participate trans-locally in the civil examinations. Arriving relatively late, they were registered by the Ming as local households. "Military people" referred to the households of the Guards and the Battalions. All people in these categories cultivated wet rice in the basins. As an indigenous ethnic group living in the mountains, Cuan people came under the authority of the A Native Official as registered civilian households of $l i$ communities and had to pay tax and render corveé service to the A family. Meanwhile, the Bo people, the descendants of Tai immigrants from southern Yunnan who arrived with Dao Ai, now served as the military force of the A Native Official. Most significantly, Ai Zixiu elucidated that indigenous people (turen 土人) included several special categories and social identities. He explained the origin of the term Bai erzi 白兒子 (literally, “sons of the Bai”) as follows:

Ashoka, the Indian emperor, who came to Dali to feed monks with white rice during the Han dynasty, was known as the King of White Rice (Baifanwang 白飯王). Therefore, his offspring became known as “the sons of the Bai (the White)". [This name] has remained unchanged for more than a thousand years. ${ }^{33}$

Ai Zixiu understood the crucial elements of the Bai identity to be rice, Ashoka and monks.

In his account of late Ming social identities, Ai Zixiu divided the indigenous inhabitants into three groups: the children of the Bai in the basin, the Cuan (Luoluo 猓玀) in the mountains, and the Bo, or Tai, immigrants from southern Yunnan. He identified these three indigenous groups using the criteria of spoken language and customs. However, he classified the three Han groups (i.e., Han people, sheren and military personnel) according to military rank and social status. The category of guest migrant people, who lived among local communities, consisted of traders, students studying to sit the examinations, and retired officials. The criteria applied by Ai Zixiu for distinguishing social identification and self-identity included factors as diverse as culture, local settlement history, types of household registration and social rank. However, certain Ming categories, such as sheren and military households, completely disappeared after the reform of the household registration system during the Ming/Qing transition. The invalidation of several previous criteria resulted in the creation of new social identities, such as the minjia 民家 (civilian families consisting of indigenous Bai) and the Han, in the early Qing. Ai Zixiu participated in the discourse on the history of the Bai people prior to the Ming. By claiming that the indigenous Bai people descended from the ancient Indian monarch Ashoka, named "the King of White Rice", Ai Zixiu offered an alternative to other stories regarding the origin of the Bai 
people. One version identified them as descending from civilians in the ancient kingdom of Bai, which was located under the White Cliff in the Midu 彌渡 basin during the late Ming and early Qing period. ${ }^{34}$ Discourses on indigenous identity and history emphasised such factors as divergent as rice farming, Buddhism or ancient local kingdoms. However, for the non-indigenous "others", such as military households and guest migrant people, it was their social ranking in connection with state institutions that mattered.

In the new 1853 edition of the Dengchuan gazetteer, Hou Yunqin and other editors simply classified the social identity of civilians as a "diverse" category that encompassed "the indigenous or the Bai" and "the Han". Hou Yunqin added new sub-categories of Han that distinguished their origins, such as the descendants of military households on state farms and registered households of guest migrants. This gazetteer recorded the presence of many rich Hui Muslim merchants and new immigrants from Burma and identified the Luoluo as inhabitants of the uplands, drawing a distinction between their occupations on the western and eastern mountains surrounding the basins: Luoluo raised stock on the western sides of the basins and engaged in mining on the eastern sides.

Accounts and discussions of social categories and identities reveal that society had changed over the 200 years from the 1640 s to the 1850 s. Two editions of Dengchuan gazetteers indicate that the reconstruction of boundaries between social groups related to their settlement history, military rank, household registration and occupation did not result in the formation of fixed, stable ethnic identities. The social mechanism for communal organisations both in basins and uplands was not shaped by language and custom but, rather, largely influenced by agriculture and the activities of local literati working within the framework of state institutions. Interaction between communities played a significant role in the continual construction of social boundaries and identities shaped by the agency of the literati and the gentry through their management of funds in communal religious practices and their organisation of rice farming irrigation. All these elements contributed to the reconstruction of social identities and boundaries between communities, not only in the basins and uplands but also between communities of different social rank and status under the framework of state institutions.

\section{Role of the gentry in the transformation of local society}

As a retired scholar-official deeply involved in community affairs, Ai Zixiu may be regarded as a representative of the gentry, a social stratum that gradually emerged during the early Ming. The gentry replaced the former elite, which declined with the transformation of Dali kingdom-style society and religion in accordance with new Ming norms that emerged in the context of new state institutions. The newly formed gentry strongly influenced the community organisations that emerged in tandem with shifts in religious practices.

Buddhism had been influential at the local level in the Dali area long before the Ming. The foundation of several famous Buddhist temples and chapels in 
Langqiong, Fengyu and Dengchuan dated to Nanzhao and Dali kingdom times. Well-known examples include such temples as Longhua 龍華寺, Zhulin 竹林 寺, Biaoleng 標楞寺, Lingjiu 靈熟寺, Jishan 積善寺 and the Ranggong Chapel 讓公庵. A stele inscription at Lingjiu Temple in Fengyu dated 1491 records the temple's reconstruction during the Yongle reign period (1402-1424) after it was burned by the Ming army. The faithful restored Buddha statues, including those of the Buddhas of the past, present and future (sanshi Fo 三世佛) and the statue of Mahākāla, the protector of the local territory 土主迦羅. The stele mentions the donation of agricultural land by many villagers to generate income for temple maintenance. The prospect of merit for their descendants motivated these donors in their acts of piety. The Three Pagoda Temple 三塔寺 controlled the Ranggong Chapel 讓公庵, which the Gao family constructed during the Nanzhao kingdom period. Friends of the famous Neo-Confucian scholar Li Yuanyang 李 元陽 (1497-1580) supported the chapel by donating funds to buy farm land for its maintenance as late as the Jiajing reign period (1522-1566). According to tradition, seven holy monks 聖僧 constructed Biaoleng Temple during the Nanzhao kingdom period. ${ }^{35}$ A stele dated 1430 (Xuande 5) records that Zhao Yanzhen 趙 彥貞 from a local family of officials renovated Longhua Temple (flourished during the Nanzhao to Dali kingdom periods) after its destruction by the Ming army. He donated agricultural land for its maintenance after he passed the civil service examination. ${ }^{36}$ These cases reveal that Dali kingdom-style patronage of Buddhist religious practice continued well into the fifteenth and sixteenth centuries. Powerful families donated farmland to accumulate merit, and their sponsorship gave them influence over large Buddhist monasteries, which in turn enabled them to control sizeable areas of farmland. It became increasingly difficult for large monasteries to maintain their landholdings after the mid-Ming because of the rise of village temples controlled by local communities.

Before the late Ming, village temples remained insignificant, overshadowed by the large Buddhist monasteries. According to stele inscriptions, certain village temples in Langqiong played an important bonding role for the people residing in various villages in the basin. For instance, Xingci Temple 興慈廟 commemorated Fengshi 豐時, who ruled the area before the Nanzhao kingdom conquered the Langqiong basin. Luofu Temple 羅浮廟 venerated the ruler of Shilang zhao 施浪 詔, a polity located in Langqiong prior to the foundation of the Nanzhao kingdom, while Huikang Temple 惠康廟 honoured Zhao Shanzheng 趙善政, the ruler of a short-lived regime between the Nanzhao and the Dali kingdoms. People at the grass-roots level celebrated the history of their local rulers through worship. Several small temples dedicated to gods performed functions closely associated with livelihoods. Lingying Temple 靈應廟 paid homage to the legendary figure Zhang Jing 張敬 for helping the Goddess of Mercy (Guanyin or Avalokiteśvara) overpower the raksha demons (luocha 羅刹) who had long plagued the people of Dali. Tradition holds that after his death, people worshipped Zhang Jing as the “god that drained the ditch" (lougou zhi shen 漏溝之神) and revered him as the deity responsible for the distribution of water resources. Another village temple memorialised an envoy from the Tang dynasty who served there as a local official. 


\section{Jianxiong Ma}

In addition to those historically associated with the Nanzhao and the Dali kingdom, other temples, such as Dragon King 龍王廟, were closely connected with the management of village water resources for irrigation and for powering mills. Village temples differed markedly from large Buddhist monasteries, which were patronised and controlled by powerful magnate families, such as the Gaos and the Zhaos, and even by prominent members of the scholar-gentry, such as Li Yuanyang. Local people managed these temples, and they functioned in ways intricately connected with everyday life. Following the decline of large Buddhist monasteries, village temples assumed increasing prominence in community life, particularly in water resource management, festivals, and labour sharing during the rice planting season.

Gentry projects for the transformation of local society by re-interpreting religious history according to Neo-Confucian thought ended up enhancing the significance of village temples. Gentry involvement in the re-interpretation of the gods worshipped at Cishan Temple 慈善廟 illustrates this point. Citing various texts in recounting the history of this temple, Ai Zixiu stressed that the strong belief in Buddhism among the inhabitants of Dali derived from the temple's proximity to India (Tianzhu 天笔):

They go to Buddhist monasteries to worship the Buddha and to feed the monks twice a month. It is commonly said that families gain eternal harmony, and thus become wealthy by believing in the Three Gems. ${ }^{37}$ Honorary officials (yiguan 義官) do not spare any expense in their construction of Buddhist monasteries, and even native officials and the wild and the intractable (jieao 桀驁) all bow and pay obeisance when they encounter Buddhist monks (ziliu 緇流). Old gazetteers record that what people commonly call the sons of the Bai are the descendants of the White Rice King, who was a Buddha. ${ }^{38}$

The case of the Holy Consort of White Purity (Baijie Shengfei 白潔聖妃) venerated at Cishan Temple in Dengchuan illustrates the extent to which the gentry's re-interpretation of local gods influenced the shift from Buddhist monasteries to village temples.

Prior to the formation of the Nanzhao kingdom, today's Dengchuan housed a polity known as Dengdan 鄧賧, with its capital at the walled city of Deyuan 德源城, literally “the city of the source of virtue". This polity was one of the four polities in the Dali area that were conquered and incorporated into the Nanzhao kingdom. In his review of the history of the unification of the polities, Ai Zixiu related the following tale:

During the Kaiyuan reign period (713-741), the ruler of Nanzhao, desired to annex the other four polities to create a kingdom, so he invited the four rulers to a banquet to celebrate the xinghui festival 星回節 on the sixteenth day of the twelfth lunar month. He set fire to the building, and then ordered the wives of the four rulers to search for their husband's bones and take 
them home. At first, Cishan, the wife of the ruler of Dengdan, could not find the bones of her husband, but she located them by searching for the iron bracelet that [she] asked her husband wear on his arm. The ruler of Nanzhao marvelled at her intelligence and strongly desired to take her as his wife. Cishan replied saying, "I have not buried my deceased husband yet, so how could I dare think of marrying again so quickly?", and then she shut tight her city gates. The Nanzhao army encircled the city, and all inside died of starvation after three months after completely exhausting their food supplies. [Before dying] Cishan declared, "I am going to report the injustice done to my husband to Heaven (Shangdi 上帝).” Horrified by this, the ruler of Nanzhao repented, and extolled her city as the "source of virtue". 39

Ai Zixiu highlighted the crucial point in the story: Madame Cishan chose to starve to death together with her people rather than re-marry her husband's murderer. Ai hinted that the Nanzhao ruler conferred honours on the city of Dengdan by re-naming it the "city of the source of virtue" out of fear of revenge from "the hungry ghosts" (egui 餓鬼) of Madame Cishan and all who died in the city.

Earlier texts provide Buddhist moral interpretations of Madame Cishan rather than underscore Confucian concepts of a wife's chastity and loyalty to her husband. One such interpretation appears in a stele inscription dated 1425 (Hongxi 1), in which local literati author Yang $\mathrm{Ci}$ 楊賜 recorded the history of Jinbang Temple 金鎊寺 near Erhai Lake. This history aids us in understanding how Madame Cishan was constructed as a goddess and how the literati represented her to local people. Yang Ci noted that in 1350 during the Mongol-Yuan period the Dali Route Commander, Duan Xinjuyi 段信直義, constructed this temple to worship four types of deity: the Four Heavenly Kings 四天王, Mahākāla 大黑天神, the Holy Consort White Sister Mother Hāriti (Beijie shengfei Helidimu 白姐聖妃訶 梨帝母), and the Bodhi Tree 菩提樹. Local communities regularly organised a parade for the deities on the eighth day of the second lunar month. Destroyed by the Ming army in the conquest of Dali in 1382, the temple was reconstructed in 1415 by the people of Changyu village 長育村, who donated farming land to generate income to support it. ${ }^{40}$ Madame Cishan, known here as the Holy Consort of White Purity (Baijie Shengfei 白潔聖妃), was recorded in later local gazetteers as the White Sister (Baijie 白姐), Pure Cedar (Bojie 柏潔), and the wife of the Dengdan ruler 鄧賧詔夫人. ${ }^{41}$ At the time of the reconstruction of Jinbang Temple in 1415 (Yongle 12), sixty-five years after its founding by Duan Xinjuyi, believers still worshipped the wife of the Dengdan ruler as the deity Mother Hāriti. Hāriti was a Buddhist goddess who protected children, aided in childrearing, parenting and family harmony, and facilitated pregnancies. She was also known as yakkha 母夜叉 or a demon. Buddhist texts record how the Buddha transformed Hāriti from a demon to a deity. Hāriti had numerous children of her own whom she loved and doted on, but she abducted and killed the children of others to feed them. To teach her a lesson, the Buddha hid her youngest son. In desperation after being unable to find him, Hāriti finally pleaded to the Buddha for help. The Buddha responded that her suffering over the loss of her son was 
the same as that of the other parents whose children she had murdered and transformed Hāriti from a demon into a Buddhist deity responsible for the protection of children. The pedigree of this goddess from the Mongol-Yuan to the late Ming reveals that Madame Cishan began as a tragic heroine, the wife of the Dengdan ruler who starved herself to death to avoid re-marriage to her husband's murderer, before being transformed into the Holy Consort of White Purity, a goddess equated with the Buddhist deity Hāriti. Cishan, literally the goddess of "benevolent goodness", from early Ming times assumed the role of protector of women and children.

However, the image of Madame Cishan as Hāriti changed significantly after the Ming/Qing transition. Literati rewrote her story to conform with Confucian ideas, and in the new version, Cishan now came to be revered as a paragon of female virtue: a model of chastity and loyalty. Feng Su 馮廷, a native of Zhejiang who had served as the Prefectural Magistrate of Yongchang and Chuxiong, repositioned the tale of Cishan within the framework of Confucian moral standards of righteous loyal males and chaste female martyrs (zhongyi jielie忠義節 烈). He articulated this fresh interpretation in the 1671 (Kangxi 10) stele he wrote for the Cishan Fei Miao, which was unearthed from its original site within the walled city of Deyuan:

There have been numerous righteous and loyal ministers over the last thousand odd years from the Tianbao reign period (742-756) until the present. Alas, [the details of] many are lost and have not been passed down to us! The rise of the six zhao [polities] was an exceptionally tiny event as it merely concerned one among the various barbarians (zhuman 諸蠻). There are countless cases of barbarian brothers (miaoman xiongdi 苗蠻兄弟) murdering each other and seizing their wives. In the beginning, nobody knew the preciousness of chastity martyrdom (jilie 節烈), and furthermore the consort despite being intelligent ended up failing to protect the descent-line and territory (zongshe 宗社) [of her husband]. Due to the successive deaths of both husband and wife, [the significance of martyrdom for chastity] vanished into the barbarian miasmas and the pestilential rain over the passage of time. Why have [people] transmitted the tale and worshipped [Cishan] until today? The [account in] the historical records of Yunnan is fragmentary, and the Bai Guji 白古記 ${ }^{42}$ is not often seen in the houses of scholars. Moreover, no erudite gentleman has carved the event in stone inside [Cishan] Consort's Temple. Her death for fidelity (sijie 死節) has only been transmitted orally by the people of Dengchuan, so the details have not been lost throughout the Song, Yuan and Ming. The details have come down to us because it is impossible to eradicate the Bonds, Constant Virtues and the sense of Great Righteousness (gangchang dayi 綱常大義 $)^{43}$ that naturally reside in the hearts of the people. ${ }^{44}$

Feng $\mathrm{Su}$ faced serious challenges to his official career when he wrote this account. Wu Sangui, the turncoat General who surrendered to the Manchus while still serving the Ming, controlled Yunnan at the time. Although he did not 
openly rebel against the Qing until 1673, Wu Sangui had already indicated his intentions in 1671. However, Feng Su did not want to participate in his rebellion even though it was $\mathrm{Wu}$ Sangui who appointed him Magistrate after he arrived in Yunnan with the Qing army in $1661 .{ }^{45}$ As a Confucian scholar living in tumultuous times of dynastic transition, Feng Su had already switched allegiance from the Ming to the Qing. However, now, his loyalty to the Qing faced a challenge from the Wu Sangui regime. It seems that when Feng Su wrote the 1671 stele, he was troubled regarding his political position. Madame Cishan became a medium through which Feng Su could express his pent-up feelings regarding loyalty. He praised the tale of Madame Cishan as a representation of the Three Bonds, the Five Constant Virtues and the sense of Great Righteousness. However, he also intended to educate the people in the land regarding "barbarian miasmas and pestilential rain" and the value of "chastity martyrdom", including its historical value, from the standpoint of Confucian ideology. Re-interpretations by later local literati also re-positioned Madame Cishan within the framework of Confucian morality in accordance with state ideology. The new Confucian version of Madame Cishan as a chaste wife loyal to her husband replaced the former image of her representing the Buddhist deity Hāriti. Although the Confucian literati embraced this metaphor of gendered loyalty, at the local level, villagers continued to worship Madame Cishan as the protective goddess of women and children.

By re-writing texts and re-interpreting the layers of meanings embodied in old texts to accord with shifts in dynastic power, the local literati educated local communities in Confucian values and played a key role in re-constructing these communities to match institutional reforms. Change progressed at a slow pace. However, it deeply altered the practice of local religion and the organisation of local communities. The endless wars and social chaos of the Ming/Qing transition disrupted local life, and dislocation wrought by floods and epidemics reshaped community relations. The abolition of the Guards and the Battalions ultimately resulted in the integration of military households into the local lijia registration system in 1687. The Yongzheng-period tax reform combined the poll tax with the land tax (diding yin 地丁銀), and this reform shifted the tax base of state power from the individual household to the village. The shift to the village enabled community leaders to create a new platform for integrating older elements into the new local culture that they were in the process of constructing. In addition, local communities provided labour for transportation and water management through the lijia system. Religious worship continued to function as a means for local communities to respond to county bureaucrats. As a result, local political and social life became centred on temples managed by $l i$ communities, and the Confucian literati used their status as gentry to gradually penetrate the political and economic lives of villagers, which brought about a cultural transformation that weakened the influence of Buddhism. With the decline of Buddhist monasteries from the Ming to the Qing, village temples came to assume an even more important role in agro-economics and the maintenance of social order. 


\section{Lijia system, religious reform and the gentry}

The early and mid-Ming saw the transformation of several large Buddhist monasteries into village temples, and these new village temples eventually replaced the large monasteries in local religious life from the late Ming onward. The rise of local leaders and Confucian literati and their subsequent control of village temples occurred as an extension of the transformation of the local elite from Dali kingdom/Mongol-Yuan period-style Buddhist scholars and magnate families into new Confucian literati deeply involved in village affairs. The literati, who were mostly men with status in the examination system and retired officials, constituted gentry in the sense used by T'ung-tsu Ch'u ${ }^{46}{ }^{46}$ The Wanli reign period (1573-1620) marked the beginning of administrative reforms that affected local society in Dengchuan county. The Ming made the county responsible for administrating military households and essentially abolished state farms. ${ }^{47}$ The Ming registered the Tai who in-migrated with the A Native Official as lijia households and settled them in forty-eight villages in Yangtang $\mathrm{Li}$ 羊塘里 during the early Ming. ${ }^{48}$ However, as a result of agricultural growth and increased population density, the A Native Official lost his administrative power over the basin population, only maintaining authority over the uplands in Dengchuan. A regular bureaucrat serving as the county magistrate and the hereditary A Native Official had jointly administered Dengchuan from its establishment in the early Ming. However, in 1569, the Ming made the county magistrate solely responsible for governance. The A Native Official only retained control of his own military force (tujun), which consisted of men from upland communities, but he exercised no authority over the affairs of the lijia households in the basins. ${ }^{49}$ These wide-ranging administrative reforms affected the military, native officials and state taxation policy and gradually homogenised the area in Dengchuan at the northern end of Erhai Lake between the early and late Ming. However, because the administrative reforms initiated the growth of new ethnic identities and created fresh cultural meanings, this tendency did not result in a simple process of "sinicisation" involving cultural unification or standardisation. These developments constitute the backdrop against which the gentry actively participated in the reconstruction of local society.

The following description by Ai Zixiu makes clear that the lijia system functioned as an institution for performing state-stipulated rituals and as a grassroots level organisation for collecting tax and procuring corveé service in Dengchuan:

The Ritual system of the Hongwu [Emperor] stipulates: "An altar for worshipping the gods of the five soils and five grains should be established for every one-hundred households in the suburbs and villages 鄉村. The five soils should be worshipped at the Spring Sacrifice (chunshe 春社) on the fifth day after the Beginning of Spring. The god of the five grains should be worshipped at the Autumn Sacrifice (qiushe 秋社) on the fifth day after the Beginning of Autumn." Each of the twelve $l i$ and four battalions in this 
sub-prefecture have set up she 社 in the monasteries and temples for worship, and moreover have established elementary schools (mengxunguan 蒙訓館) inside them. ${ }^{50}$

It was because the twelve $l i$ represented communities as well as administrative units that the state established she 社 in the "monasteries and temples for worship" in Dengchuan. By harnessing the twelve $l i$, the Ming ensured that communities performed rituals at the right time to reap good harvests. Every $l i$ had three li Elders (lilao 里老). The first, known as "the Wooden Bell Elder" (muduo laoren 木鐸老人), was responsible for patrolling the community and providing moral instruction. The second, known as "the Community Covenant Elder" (xiangyue laoren 鄉約老人), handled minor legal adjudications, mediated economic disputes, maintained peace and order, and helped local bureaucrats communicate with households in the li community. The third, known as the “Labour Management Elder" (guangong laoren 管工老人), organised manpower for labour service. This position became defunct with the reform of the tax system. Each elder received three dou 斗 of grain (approximately $45 \mathrm{~kg}$ ) per month as remuneration. In addition, there were li captains (lishang 里長), who together with the jia heads collected and shipped the grain tax of the $l i$ and bore responsibility for drawing up and implementing the labour service roster. After the commutation of the grain tax to payment in silver, $l i$ captains still had to ensure that payments were made in full. To maintain order in society, the bureaucrats introduced a system of collective responsibility known as the baojia 保甲 that encompassed all households. In theory, one bao consisted of ten jia (10 households per jia), and ten bao formed one $l i$ 里, or xiang 鄉. The bureaucrats assigned each household a house number (menpai 門牌) irrespective of status or wealth and recorded the number of household members, the amount of normal harvest and the types of weapons possessed. This security system aimed to make all households in the jia collectively responsible for crimes or misdemeanours. Ai Zixiu left the following description of the system's operation in Dengchuan:

If fire breaks out in one family, the other nine families provide emergency assistance; if one family steals, the other nine families are responsible for stopping it; thus, the system could effectively be managed by the jia heads. Strangers and outlaws (miansheng dairen 面生歹人) cannot lodge at inns (dian 店) or go through mountain passes. Gambling, which is strictly prohibited, will not be tolerated on commercial premises, or in private retreats (bieshi 別室). Itinerant Buddhist monks and demonic Daoist priests will not be able to stay at Chapels 庵, Halls 堂, Buddhist monasteries and Daoist temples. ${ }^{51}$

The Single Whip (yitiao bianfa 一條鞭法) reforms of the second half of the sixteenth century converted certain regular lijia labour services and miscellaneous labour levies into a single payment in silver. These new measures shifted 


\section{Jianxiong $M a$}

the unit of tax assessment from the $l i$ to the counties and sub-prefectures and required individual taxpayers to deliver their commuted tax payments in person. The lijia no longer had to handle the delivery of grain tax and to organise labour service under this new arrangement..$^{52}$ The implementation of these new policies progressed slowly, only reaching completion during the Yongzheng reign period.

Because the $l i$ and jia units still handled certain regular labour services and additional labour services were assigned to these units, these reforms did not reduce the burden of registered households. The endless wars in the late Ming period and the change in the currencies circulating on local markets in Yunnan increased the burden of peasant households. Shell money and copper coins had circulated as local currency for a long time. However, with the introduction of the Single Whip reforms, the state only accepted tax payments in silver, and the greater demand caused an increase in the price of silver. For peasant households only holding shell money or copper coins, this increase caused a substantial increase in the amount of tax paid, and the bureaucrats profited from the difference in exchange rates. ${ }^{53}$ In addition, the $l i$ and jia in the basins along the main thoroughfares in Yunnan still had to provide labour and horses for transportation ( fuma tanpai 夫馬攤派) from the Ming until the late Qing.

The transportation route for officials travelling between Dengchuan subprefecture and Heqing prefecture was managed by two post stations from the early Ming. Dengchuan sub-prefecture was responsible for assigning labour service for transportation by mule caravan and receiving officials travelling from the lower station (xiazhan 下站) in Dali to the upper station (shangzhan 上站) in Heqing. The distance between Dali station at Erxiyi 洱西邑 village to Dengchuan station was $45 \mathrm{~km}$, and the distance from Dengchuan to Guanyin mountain station in Heqing prefecture was approximately the same. ${ }^{54}$ After General Wu Sangui rebelled against the Qing in 1673, the Wu regime assigned Heqing prefecture's responsibility for providing labour service for official travel and transportation to Langqiong sub-prefecture. Langqiong originally paid 72 liang silver (approximately 95 ounces) per year for the Guanyin Mountain section. However, now, it had to provide an additional twenty men for labour service. As a result, each lijia unit in Langqiong paid the silver required on a rotating basis and provided men for duty each day to serve the needs of travelling officials. The local gentry of Langqiong were highly dissatisfied with this arrangement, and brought a lawsuit against Heqing prefecture. To settle the issue, the yamen of the Yunnan-Gui Governor-general abolished Langqiong's service assignments for transportation but still required the communities of Dengchuan to pay 48 liang silver (approximately 63 ounces) annually for Heqing to handle transportation. ${ }^{55}$ This lawsuit reveals that the local economy had undergone substantial changes with the integration of the Guards and Battalions into the lijia, the abolition of the Dengchuan Native Official, and the introduction of the Single Whip reform since the Wanli reign period. In addition, mines were opened in the uplands on the border between Dengchuan and Heqing prefecture during the late Ming. A silver mine known as the Yushi Mine 玉獅廠 flourished and attracted 
many migrants from other provinces. Increased population density and the construction of irrigation facilities changed society in the three basins of Dengchuan, Langqiong and Fengyu. The villages that grew out of the lijia became increasingly powerful when the gentry assumed leadership of local communities. Complex social identities based on residential settlement shifted during the early Qing dynasty as a result of administrative reforms that eliminated social categories such as military households, which simplified local identities into the categories of Han households 漢家 and Minjia民家 (Civilian households) for the indigenous Bai people. Along with the growth of new village communities, the gentry gained increasingly greater power over village affairs, and their influence was prominent in moral instruction and religious activities.

An example of moral instruction by Neo-Confucian scholars appeared in the writings of Yang Nanjin 楊南金, a metropolitan degree holder of 1499 who was born and bred in Dengchuan. He authored a treatise entitled the Sanjiao Lun 三 教論 (Discussions on the Three Teachings) and maintained close associations with the renown Dali scholar Li Yuanyan 李元陽 and the exiled Sichuanese scholar Yang Shen 楊慎. Yang Nanjin hailed from an indigenous Bai civilian family and was not a member of a Han military household. After retiring from bureaucratic service, he took a deep interest in local affairs and enthusiastically wrote about the need to reform local customs and practices in his Xixinquan Bei 洗心泉碑 (Spring for Washing Hearts Stele), dated 1519 (Zhengde 14). This stele commemorates the completion of a project to divert running water from a spring for everyday use in the sub-prefectural city of Dengchuan. Yang Nanjin wanted the local people to "wash away" certain old and new practices that he regarded as detrimental to social order in the $l i$ and jia. He described the practices that he disliked in a five-word poem titled Tuzhu Bian 土著變 (Local Change). To better understand what he wanted to "wash away", I translate the poem into prose below:

Grandchildren inherit fields watered by valley streams (xitian 溪田) measuring three to five shuang 雙 [approximately 15 to 20 acres] ${ }^{56}$ from their grandfathers and fathers. They cultivate and herd wearing large conical bamboo hats and palm-bark raincoats, and they are content with coarse clothing and rough food. Marriages are arranged by divination, and illnesses are cured by earnestly praying to ghosts. In worshipping ancestors, they use two stone vases (shiping 石瓶), and offer meat known as "three-year pork". They exert efforts to strengthen their doors and rely on each other for security against bandits. The older generation follows the Buddhist scriptures (zhi foshu 知佛書), and always regards extravagance as a disgrace. Ancestral graves have not been changed or moved without good reason for several generations. In recent years, mixing with the military and the merchant households, people now pursue trivial profit (zhumo 逐末) and have distanced themselves from agriculture (leisi 未耤). Although some people study the Confucian classics, they fail to comprehend the rationale ( $l i$ 理) behind [the teachings of] the sages and worthies. Cunning people deceitfully 
use their skills at writing official documents (daobi 刀筆) to spoil the goodwill and honesty of past human relations within the li (xirenli 昔仁里). Now, people value rare food and gorgeous clothing and are not frugal in their use of money. Real estate (hengchan 恆產) disappears as quickly as boiling water melts snow and looking around I see people becoming hungry and cold everywhere. Chaos has arisen due to people taking no action, and they just cast side-long glances, as they cannot handle the situation. We cannot obtain good people by mollifying their will to conform 拊循. ${ }^{57}$

It is clear that Yang Nanjin wanted to "wash away" three things: the people's esteem for Buddhism ("The older generation follows the Buddhist scriptures"), the new trend for pursuing commercial gain ("trivial profit"), and the penchant for an extravagant lifestyle. Juxtaposing these undesirable practices with the simple and rustic life in the $l i$ and the jia, he emphasised the incompatibility of old and new practices with state orthodoxy and Confucian ideals. In the stele of 1519 , he invoked the idea of washing the heart to transform people's soiled mind-sets. He requested Elders (fulao 父老) “to wash away the old dirt and cultivate new goodness", proclaiming that henceforth "you cannot use cremation when burying [the dead]" and "you cannot become Buddhist monks and Daoist priests". In addition, he exhorted people to "exert themselves at agricultural cultivation, diligently read the classics and the standard histories, take strict precautions against water and fire, and protect the safety of their families". ${ }^{58}$

A number of high-ranking officials and members of the local scholar-gentry advocated the reform of customs and practices in western Yunnan from the 1490s to the 1570s. For instance, Provincial Surveillance Commissioner Lin Jun 林俊, a native of Putian county in Fujian, ordered the destruction of more than 360 temples in Heqing in 1488, and Li Yuanyang prohibited cremation in Zhaozhou 趙州 south of Erhai Lake during the 1570s. Li Yuanyang wrote, henceforth "it is not permitted to lightly cremate deceased blood relations", and he enforced this order by making households in the $l i$ and jia mutually responsible for ensuring that everyone complied; all households in the group would be punished along with the offender. ${ }^{59}$ Cremation had associations with Dali kingdom-style Buddhism. Thus, by prohibiting its practice, the scholar-gentry distanced local people further from pre-Ming practices. These examples demonstrate that efforts by the scholar-gentry and the literati to reform local customs aimed to transform the mind-sets of the local elite. The goal was to make the local elite identify with Ming social and political ideology. They encouraged the local elite to embrace the idea that success in the examination system would provide men access to bureaucratic office. Ultimately, this encouragement resulted in increasingly larger numbers of men studying for the examinations in Langqiong and Dengchuan.

Wang Mingke 王明珂 has observed that renowned Langqiong scholar Wang Song 王崧 (1752-1837) stands out as an archetypical traditional historian who contextualised local history within orthodox central-plains ideology. 
In compiling and editing state-sponsored historical works, Wang Song positioned local polity leaders and hereditary magnate families of the Nanzhao and the Dali kingdom periods within the framework of the standard histories, thereby transforming local history into a sub-division of the larger category of central plains-based history. ${ }^{60}$ Although not the first to attempt such contextualisation, in his writings, Wang Song emphasised the role of gentry and literati in the long-term reconstruction of local communities to accommodate administrative reforms from the sixteenth century. It was this social group that led the local communities in adjusting themselves to changes wrought by the dynastic state.

\section{Establishment of common property based on village temples}

The elimination of the political power that sponsored Dali kingdom-style Buddhism in the early Ming initially resulted in state-orchestrated shifts in the ownership of the wet field landholdings of large Buddhist monasteries (changzhu tian 常住田). However, by the mid-Ming, certain of these landholdings had fallen into the hands of powerful landlord families. This change is evident in the case of Biaoleng Temple 標楞寺, located near Cibi Lake 茈碧湖 in Langqiong. Tradition holds that this temple originally founded by an Indian Monk (Shengseng 聖僧) constituted one of the “outer eight altars (wai ba tanchang 外八 壇場)" sponsored by the Dali kingdom. According to a stele of 1573 (Wanli 1), Zhang Dan 張䋁, Left Commissioner in the Yunnan Provincial Administration, transferred control of the wet fields belonging to Biaoleng Temple to the Dali monk Wuji 無極 when the Ming appointed the latter Superior of the Prefectural Buddhist Registry (senggang si dugang 僧綱司都綱) and assigned all MongolYuan period temple lands to him during the Hongwu era. However, influential families (haoyou 豪右) had gained control of most of the Biaoleng Temple wet fields by the Zhengde reign period (1506-1521). ${ }^{61}$ Furthermore, in 1684, monks reconstructed the monasteries and shifted the ownership of the wet fields to influential families. ${ }^{62}$ The general trend was for the ownership of temple land to shift into private hands as the landholdings of large Buddhist monasteries decreased in size.

As large Buddhist monasteries declined, several settlements known as "villages" turned into units for managing affairs related to irrigation, and residents donated wet fields to generate income for use by their village communities. This development marked the emergence of a new management system based on income from common property. A recent stele inscription of 2004 records that this change occurred during the late Ming, when three villages (Yongxing 永興, Yongfeng 永豐 and Changle 長樂) near Cibi Lake located at the margins of the Langqiong basin collectively dug an irrigation ditch along a mountainside named the Upper Ditch of the Changle Village God. The ditch linked streams to irrigate more than 1,200 mu (approximately 200 acres) of rice land. This joint project was not managed by a large Buddhist monastery but by a village temple. ${ }^{63}$ From the late Ming, the village became the unit for performing 


\section{Jianxiong $M a$}

hydrological construction projects in the basins of Langqiong, Fengyu and Dengchuan. However, because the distribution of villages reflected the ecological requirements of rice farming, villages did not always neatly fit the administrative units of $l i$ and jia. Therefore, when organising civilian households into the $l i$ and jia, bureaucrats had to adapt administrative units to accord with the size of villages to ensure that the distribution of water and the construction of irrigation channels could be conducted jointly.

The relatively small size of the Langqiong and Dengchuan basins made co-operation and alliances between villages essential for the construction and the maintenance of irrigation facilities. In the case of the 4 kilometre-long Upper Ditch of the Changle Village God, labour was required from the three villages to complete the project. Villages in the basins of western Yunnan often jointly undertook small-scale hydraulic projects that involved digging ditches to link streams and springs on mountainsides with pools and small reservoirs, from which water could be distributed to rice fields at lower elevations through gravity. These irrigation systems were primarily used in the spring before the arrival of the monsoon rains, and the ditches could be used to channel excess water into larger rivers to avoid flooding during the wet summer months. These small-scale irrigation systems distributed water from the slopes at the margins of basins towards the centres, particularly towards lakes and rivers located in the middle of the basins. They were smaller in scale than the large hydraulic system on the Miju River and to highlight this difference, I refer to them as a "basin irrigation" system. Irrigation systems jointly managed by multiple village communities gradually increased in the Langqiong and the Dengchuan basins after the late Ming. Village temples generated income from common property for their construction, repair and maintenance. Thus, the temples gradually assumed the role of centres for water management and ritual practices for all societies in the basins, irrespective of ethnic identity, household registration category or social class of the villagers. In this way, jointly operated small-scale irrigation systems contributed to the formation of new local communities, each dependent on the sharing of water resources for wet rice cultivation and collective religious practices.

As previously mentioned, the large Buddhist monasteries lost control over their land and tenants during the late Ming/early Qing period. This process progressed in tandem with the Neo-Confucian literati ceasing to support the monasteries and the rise of gentry involvement in local affairs. This trend is evident in an incident that occurred at Lanruo Temple 蘭若寺 in Dengchuan, whose founding dates to the Mongol-Yuan period. This monastery controlled $93 \mathrm{mu}$ (approximately 15.5 acres) of irrigated farming land and relied on the income from the rents to feed the monks and pay tax. During the Wanli reign period (1573-1620), the gentry of three neighbouring villages mobilised the tenants of Lanruo Temple and the $l i$ captains to block water from flowing into the temple's wet fields before the arrival of the rains, just when water was sorely needed to irrigate transplanted rice seedlings. The monks filed a court case against the gentry. However, the County Magistrate only granted the monks one-fourteenth 
of the water, giving the villages the largest share. In 1706, the villagers completely blocked the water source for irrigation. ${ }^{64}$ The Lanruo Temple example highlights the increasing trend for the control of resources, such as agricultural land and irrigation water, to gradually shift to villages as large Buddhist monasteries lost support from county bureaucrats and believers during the Ming/Qing transition period. By gaining complete control over water sources during the early Qing, the gentry and their village followers severely undermined the ability of the large monasteries to maintain themselves because the lack of irrigation made their wet fields untillable and therefore worthless.

A guaranteed supply of water for transplanting rice seedlings before the rainy season was crucial for wet rice cultivators. As representatives of village communities, the gentry drew up agreements concerning water distribution and mediated conflicts to make the irrigation system viable. Several cases reveal that as late as the 1790s, most villages in Langqiong had drawn up agreements for water distribution during the two-month rice transplantation period, and these agreements had the endorsement of county magistrates. These agreements for distributing water on a rotating basis emerged when the village gentry gained control of irrigation water.

To illustrate this point, I cite three relevant episodes from the Langqiong basin. Four villages in the basin used to send their men to fight for water to irrigate their fields when transplanting rice seedlings before the Mangzhong 芒種 solar term, normally around 6 June. Because of the prolonged nature of the conflicts, the gentry intervened and finally struck an agreement that teams of young men from the villages would jointly distribute the water on a rotating basis. ${ }^{65}$ Five villages in another part of the Langqiong basin irrigated their fields by sharing water channelled from two mountain streams. The five villages jointly established Huikang Temple 惠康廟, a Benzhu temple 本主廟, for the worship of a god known as the Emperor Zhao Shanzheng 天子趙善政. The temple also venerated a god known as Woodcutter Blue (Qiaoqingshen 樵青神), who possessed the ability to distribute water. Since Woodcutter Blue and the gods of the two mountain streams obeyed the instructions of the Emperor Zhao Shanzheng, all five villages jointly established common wet fields (gongtian 公田) and worshipped them collectively. The founding of this temple signified the eligibility of all five villages to receive shares of water and emphasised that only the deity Zhao Shanzheng possessed the ability to distribute the water fairly. The early Qing saw the introduction of a new festival in which villagers carried the images of the deity and his family members on sedan chairs around all five villages between the eighteenth and twenty-first days of the first lunar month. Expressing the god's capacity to protect the territory of the five villages, the images of the deity visited villages in the same rotational order in which water was distributed ${ }^{66}$ Water flowing down slopes in mountain streams or from upland springs provided gravity-fed irrigation. However, the nature of the terrain limited the size of such irrigation systems. Therefore, as previously mentioned, communities sharing a common source of water normally only encompassed three to five villages. 
A relatively large alliance of eleven villages in the Dengchuan basin shared a common water source. The common property of the alliance was managed by a committee at Dongchuan Great Temple 東川大廟 (where the Dragon God 龍神 was worshipped), which was also responsible for maintaining a small river and the irrigation channels branching from it. The temple committee, which consisted of gentry from all eleven villages, had written regulations for management and constructed a water-driven mill (duimo 碓磨) on the river. The managers used the income from renting out the mill to cover expenses for running the common property. People from the eleven villages worked in two shifts to operate the mill. The managers divided the small river into eleven sections, and each village repaired and performed maintenance on its own section during the second and eighth lunar months each year. The gentry of each village organised labour to work on their own sections. Originally established for religious purposes, the gentry used Dongchuan Great Temple as a venue for the Dongjing Assemblies 洞經會, which were held twice yearly, first on the deity's birthday on the fifth day of the first lunar month and second for the assembly celebration (huiqingzhu 會慶祝) on the twenty-third day of the seventh lunar month. The gentry of each village hosted the assemblies in rotation in the same way as with water distribution. The 1884 (Guangxu 10) stele for Dongchuan Great Temple emphasised that each village had to take turns:

The assembly for "speaking about the sutras (tanjing 談經 [Dongjing Assembly])" at the time of ritual ceremonies in spring and autumn must be hosted by each group according to the order of rotation in the past.

The stele lists the names of the villages in order from one to eleven. ${ }^{67}$ Certain names indicate an origin as villages of military households, such as, for instance, Liu Family Official Camp 劉官營, Chen Family Official Camp 陳官營 and Official Manor 官莊. However, by the 1790s, the past history of villagers as military households and Bai civilian households no longer mattered because village temples had become centres for inter-village religious practices and community festivals, for the management of common property, and for village assemblies for elderly male and female members. Many features that we now associate with local Bai culture emerged and gained popularity from c. $1820 .^{68}$

Another example that illustrates the agency of the gentry in the construction of new communities and the management of common property after the early Qing is the case of a sulphur spring known as the Jiuqitai hot spring九氣台溫泉 managed by a village of the same name. Characteristic features of the hot spring included two large stone slabs shaped like a snake and a turtle, which represented male and female power. Villagers constructed a temple dedicated to the god Zhenwu 真武 the True Warrior above the stone slabs near the spring pools. ${ }^{69}$ Local people bathed at the hot spring pools to heal skin diseases. However, from 1856 to 1873 during the Du Wenxiu Rebellion, the Muslim army used the sulphur for making gunpowder. After the return of the hot springs to the village in 1873 , the village temple committee continued to produce sulphur 
and following past custom paid the income derived from its sale into the account of the village temple Xuandi Ge 玄帝閣 for collective use by the village. The county government also issued the village a licence, thus legalising its sulphur production.

The establishment and maintenance of common property is an important focus for understanding the formation of local history and culture from the early Qing. Establishing common property was much more than a village response to the state's lack of support for constructing hydrological infrastructure, such as ditches and channels. It also aided the formation of new village communities after the demise of state-imposed categories of household registration and the termination of social control through the lijia system. The new communities integrated indigenous and migrant households of the Ming and created new local identities. In this way, the common-property management system served as a mechanism for re-constructing basin societies in western Yunnan. Common property constituted a public institution because it was shared by all village members, held under the name of village temples, and managed by the gentry and village leaders. This new social environment gave rise to intermarriage between families with diverse histories of household registration and even between different ethnic groups. However, such intermarriage did not result in the adoption of patrilineal lineages or family and kinship principles as important criteria for community organisation. The agency of the local gentry played an important role in the reconstruction of common property-based local communities under the changed social circumstances of the early Qing dynasty. This agency contributed to the holding of common property by villages becoming a social norm bound up with religious practices shared by community members. Cohesiveness between village communities was extremely strong in the latter half of the nineteenth century during the turmoil of the Du Wenxiu Rebellion and its aftermath, when local society was thrown into chaos and state power weakened. ${ }^{70}$

\section{Conclusion}

In this chapter, we have noted how factors such as state policy and land property rights deeply influenced shifts in local society. The three Ming institutions of native officials, the military and regular administrative units changed the economic bases of large Buddhist monasteries dating to the Mongol-Yuan period. The introduction of different household registration categories and the use of the lijia system to collect grain taxes, assign labour services and to control local society created multiple individual communities in the Dengchuan, Fengyu and Langqiong basins. These state-imposed social categories can be regarded as the institutional origin of the ethnic identities of indigenous inhabitants in the Ming as well as a method of distinguishing them from diverse groups of immigrants. However, the lijia system did not re-shape social relations based on the need for stability in access to water resources. Co-operation for water distribution was achieved after long-term conflicts and through the religious activities of village 
temples. It was because village temple systems for the joint management of labour and water resources replaced state institutional authority at the local level that local elites, such as the gentry and village leaders, gained the leeway required to innovatively reconstruct communal ties by binding them to religious practices and family organisation and forging inter-community links.

From the late Ming to the early Qing, the $l i$ and jia community became less constrained by the state because of changes in policies regarding taxation and labour services. However, at the same time, the Neo-Confucian literati became increasingly involved in moral instruction. The gentry in rural villages played significant roles in public education, religious practice and irrigation facility construction as well as in the management of common property for constructing larger social alliances beyond the boundaries of family, kinship, and $l i$ and jia units. In this way, the social agency of the gentry became increasingly important for integrating the diverse state-imposed categories into new communities from the early Qing. Meanwhile, because the gentry now had more flexibility than before, they were able to reconstruct village temples into hubs for organising local society. Villagers also regarded these temples as public spaces for the purpose of co-operative negotiation and for negotiating with state power. Therefore, village temples came to assume a role that extended well beyond simple religious activities. Villages organised committees to manage common property, and these committees replaced the influential large Buddhist temples of the past. This shift was accompanied by a transfer of agricultural land under the control of magnate families and monasteries to the hands of village gentry. The fall of the Ming witnessed the disappearance of the diverse identities created by the Ming state household registration. Three new ethnic identities emerged to replace past categories. Now, there were only the Minjia and the Han in the basins and the Luoluo (the Yi) in the uplands under the jurisdiction of native officials. That is, the Qing did not in fact "sinicise" ethnic peoples in the Dali area. What occurred was that the diverse local identities of the Ming classification system were transformed into a new style of ethnic relations and identities. Thus, this transformation did not constitute a "sinicisation" process as claimed by certain scholars ${ }^{71}$ but, rather, a re-definition of non-Han ethnic groups.

Co-operation between the state and the local elite shaped the reconstruction of social life and cultural practices. It facilitated social reforms, including a high level of elite involvement in local society, particularly in irrigation management, labour sharing, and the promotion of goods circulation through long-distance trade. The gentry provided leadership for villagers in their extension of local public space and social ties. Members of local communities themselves became the interpreters of religious rituals, festivals, and the moral instruction of the gentry endorsed by the state. Ethnic identities formed in relation to villages and the alliances between villages centred on Benzhu temples. In the process of creating new identities, village identity became a means of interpreting ethnic differences, and in fact, the Bai nationality adapted village identity as an ethnic marker after 1949. In sum, ethnic culture and ethnic identity has formed slowly over a long time. It has emerged in response to shifts in state institutions and 
embodies the historical experience of local people continually adjusting their orientations to reconstruct social ties in the face of change. When village temples became a hub for worshipping common ancestors of villagers and the management of common property, they also provided venues for evaluating family fame and resolving disputes between families.

Village temple inscriptions and local gazetteers mostly record the activities of the local elite, particularly the gentry, as leaders of village organisations, seldom mentioning $l i$ and jia units. The local elite dominated the committees that managed temple property and handled assignments from the state throughout the Qing period. They also organised festivals, Taoist assemblies, repairs of irrigation facilities and other affairs at the local level. The common property of village temples was used for the benefit of all constituent members. It was not privately owned by anyone but founded on the notion of shared ownership; the temples were constructed for the "public" or "common (gong 公)" good.

This chapter demonstrates that although shifts in state policies established an institutional framework for the transformation of local society from the early Ming to the Qing, it was the change of local elites that led to the reconstruction of local communities in the basins of western Yunnan. These basins cannot be simply regarded as a frontier area devoid of specific regional and local agency for social transformation. It was through the agency of local elites and village leaders that new social structures and ethnic identities were created during the long historical process of change from the Dali kingdom period to the Qing period.

\section{Notes}

1 This research was supported by the Hong Kong Research Grants Council (RGC) General Research Fund Project (No. 16655916).

2 Eryuan county covers an area of approximately 2,600 square kilometres; see www. ey.yn.gov.cn/eygov/1585548543811125248/20141022/29782.html, homepage of Eryuan county government, last accessed on 16 October 2016. (洱源县人民政府门 户网站, 2016.10.16.).

3 James L. Watson, "Chinese Kinship Reconsidered: Anthropological Perspectives on Historical Research", China Quarterly, Vol. 92 (1982), pp. 589-622.

4 Zhao Min and Tik-Sang Liew, Eds., Yun-Gui Gaoyuan De "Baisi Shehui”, p. 1.

5 Eryuan Xianzhi Bianweihui, Ed., Eryuan Xianzhi, p. 45.

6 Mark Elvin, Darren Crook, Shen Ji, Richard Jones and John Dearing (2002), pp. 1-60.

7 Eryuan Xianzhi Bianweihui, Ed., Eryuan Xianzhi, p. 1.

8 Eryuan Xianzhi Bianweihui, Ed., Eryuan Xianzhi, p. 49.

9 Eryuan Xianzhi Bianweihui, Ed., Eryuan Xianzhi, p. 79.

10 Ma Jianxiong (2014). There are ninety-three Bazi basins in Yunnan larger than fifty square kilometres in area. However, in total, the Bazi basins only occupy approximately 6.52 per cent of the total area of the province.

11 Eryuan Xianzhi Bianweihui, Ed., Eryuan Xianzhi, p. 55.

12 “Hou Zhonglu Xiansheng Zhi Xingji Bei 侯鐘麓先生之形迹碑 (Stele on the Achievement of Mr. Hou Zhonglu)", in Zhao Min and Wang Wei, Eds., Dali Eryuan Xian Beike Jilu, pp. 180-182.

13 For the circulation of goods see chapters in Eric Tagliacozzo and Wen-Chin Chang, Eds., Chinese Circulations and Networks in Southeast Asia. 
14 Eryuan Xianzhi Bianweihui, Ed., Eryuan Xianzhi, p. 1, p. 31.

15 See Charles O. Hucker, A Dictionary of Official Titles in Imperial China. p. 79.

The basic garrison unit was a Guard (衛), headed by a Guard Commander (指揮 使). Each Guard was normally named after the prefecture or sub-prefecture where it was based and in theory consisted of 5,600 hereditary soldiers. A Guard theoretically had five Battalions (千户所) of 1,120 men, each divided into ten Companies (百户所). Companies, and even Battalions, were often garrisoned apart from the Guards to which they belonged, and there were some Independent (守御) Battalions that were controlled directly by Regional Military Commissions (都督府) and were not parts of Guards.

16 In theory, 110 neighbouring households constituted one $l i$ or a community. One $l i$ consisted of ten jia 甲 (ten households per jia), one li captain 里長 and nine jia heads 甲首, for a total of 110 households; see Charles O. Hucker, A Dictionary of Official Titles in Imperial China, p. 78. The lijia system aimed to share out taxes and labour services equitably among all the households in the $l i$. For an account in English of how the system functioned as an instrument of local control, see Tsurumi Naohiro "Rural Control in the Ming Dynasty", in Linda Grove and Christian Daniels, Eds., State and Society in China: Japanese Perspective on Ming-Qing Social and Economic History, pp. 245-277.

17 Ai Zixiu, Compiler, Chongzhen Dengchuan Zhou Zhi, p. 8; Hou Yunqin 侯允欽, Xianfeng Dengchuan Zhou Zhi, juan 3, p. 5.

18 Zhao Gongxiu, Kangxi Langqiong Zhou Zhi, juan 7, p. 4.

19 Mark Elvin, Darren Crook, Shen Ji, Richard Jones and John Dearing (2002), pp. $23-51$.

20 Ai Zixiu, Compiler, Chongzhen Chongxiu Dengchuan Zhou Zhi, p. 8; Hou Yunqin, Xianfeng Dengchuan Zhou Zhi, juan 2, p. 13.

21 Eryuan Xianzhi Bianweihui, Ed., Eryuan Xianzhi, p. 9; Hou Yunqin, Xianfeng Dengchuan Zhou Zhi, juan 9, p. 18.

22 Eryuan Xianzhi Bianweihui, Ed., Eryuan Xianzhi, p. 10.

23 “Gaogong Muzhi Bei 高公墓志碑 (The Tomb Inscription of Duke Gao)", in Zhao Min and Wang Wei, Eds., Dali Eryuan Xian Beike Jilu, p. 14.

24 Ni Tui, Dianyun Linian Zhuan, p. 175.

25 "Gaogong Muzhi Bei", in Zhao Min and Wang Wei, Eds., Dali Eryuan Xian Beike Jilu, p. 14.

26 Zhou Hang, Guangxu Langqiong Xian Zhilue, juan 13, p. 3.

27 Ai Zixiu, Compiler, Chongzhen Dengchuan Zhou Zhi, juan 1, p. 9.

28 Hou Yunqin, Compiler, Xianfeng Dengchuan Zhou Zhi, juan mo, p. 54.

29 “A Shi Wushi Mubiao Be i 阿氏五世墓表碑 (The Tomb Inscription of Five Generations of the A Family)", in Zhao Min and Wang Wei, Eds., Dali Eryuan Beike Jilu, pp. $18-19$.

30 The ten Police Offices were also administered by hereditary families, such as those of native officials. These hereditary families included the $\mathrm{Zi}$ 字氏 and the $\mathrm{Li}$ 李氏 families, who controlled the transportation routes to the salt wells in the Yunlong area; the Yang 楊氏 family at the Upper Five Salt Wells 上五井; the Li family 李氏 at the Shundang Salt Wells 順蕩井; and the Yang family 楊氏 at the Shijing Salt Wells 師 井 in the Yunlong area. In addition, the routes from Dengchuan to Heqing were controlled by the Yang 楊氏 family of Shangjiangzui 上江嘴, the He 何氏 family of Xiajiangzui 下江嘴, the Yang 楊氏 family of Qingsuobi 青索鼻 and others. See Hou Yunqin, Compiler, Xianfeng Dengchuan Zhouzhi, juan 10, p. 30.

31 Christian Daniels "Historical Memories of a Chinese Adventurer in a Tay Chronicle", pp. 33-34.

32 Hou Yunqin, Compiler, Xianfeng Dengchuan Zhouzhi, juan 12, p. 15.

33 Ai Zixiu, Compiler, Chongzhen Dengchuan Zhou Zhi, juan 1 zulei 族類, p. 9. 
34 Zhuang Cheng, Wanli Zhaozhou Zhi, "Preface".

35 Zhou Hang. Guangxu Langqiong Zhilue, juan 6, p. 6.

36 “Chongxiu Longhuasi Jibei 重修龍華寺記碑 (Inscription on the Renovation of the Longhua Temple)", in Zhao Min and Wang Wei, Eds., Dali Eryuan Beike Jilu, p. 10.

37 The Three Gems 三寶, triratna [S] consist of the three components of Buddhism: the Buddha, Buddhist law [Dharma], and the monastic community [Sangha].

38 Ai Zixiu, Compiler, Chongzhen Dengchuan Zhou Zhi, juan 1 zulei 族類, p. 15.

39 Ai Zixiu, Compiler, Chongzhen Dengchuan Zhou Zhi, juan 1 zulei 族類, pp. 15-16.

40 “Chongxiu Jinbangshan Ji Bei 重修金鎊山記碑 (Stele Record of the Renovation of Jinbang Mountain Temple)", in Zhao Min and Wang Wei, Eds., Dali Eryuan Beike Jilu, p. 8.

41 Zhao Gongxiu, Kangxi Langqiong Zhou Zhi, Vol. 7, p. 6; Zhou Hang, Ed., Guangxu Langqiong Xian Zhilue 浪穹縣志略, juan 6, p. 6.

42 This name refers to the Bo Gu Tongji 來古通記.

43 Gangchang 綱常 refers to the Three Bonds and the Five Constant Virtues (sangang wuchang 三綱五常). The Three Bonds are the superordinate and subordinate ties between prince and minister, father and son, and husband and wife. The Five Constant Virtues are benevolence, righteousness, propriety, wisdom and fidelity.

44 “Cishan Fei Miao Jibei 慈善妃廟記碑 (Stele of the Record of the Cishan Consort Temple)", in Zhao Min and Wang Wei, Eds., Dali Eryuan Beike Jilu, p. 57.

$45 \mathrm{Li}$ Xiaoyou 李孝友 and Xu Wende 徐文德, Diankao Jiaozhu 滇考校注 (Annotated Version of the Diankao) (Kunming: Yunnan Minzu Chubanshe, 2002).

46 See Ch'u T'ung-tsu, Local Government in China under the Ching.

47 Ai Zixiu, Compiler, Chongzhen Dengchuan Zhou Zhi, juan 1 zulei 族類, p. 9.

48 Ai Zixiu, Compiler, Chongzhen Dengchuan Zhou Zhi, juan 3 fengjing zhi 風景志, p. 16.

49 Ai Zixiu, Compiler, Chongzhen Dengchuan Zhou Zhi, juan 5 guanshi 官師, p. 36.

50 Ai Zixiu, Compiler, Chongzhen Dengchuan Zhou Zhi, juan 12 cisi zhi 祠祀志, p. 101.

51 Ai Zixiu, Compiler, Chongzhen Dengchuan Zhou Zhi, juan 5 guanshi 官師, p. 39.

52 Tsurumi Naohiro "Rural Control in the Ming Dynasty", in Linda Grove and Christian Daniels, Eds. (1984), pp. 266-273.

53 Ai Zixiu, Compiler, Chongzhen Dengchuan Zhou Zhi, juan 6 xianfa zhi 憲法志, p. 42.

54 “Xiazhan Kangxi Wuyin Bei 下站康熙戊寅碑 (The Inscription on the Lower Station in 1722)", in Zhao Min and Wang Wei, Eds., Dali Eryuan Beike Jilu, p. 76.

55 Zhao Gongxiu, Ed., Kangxi Langqiong Zhou Zhi, juan 7, p. 21.

56 The term shuang 雙 is a unit of land area measurement used from the Nanzhao period. One shuang is equivalent to four $m u$. See Pan Chuo 攀綽's Manshu蠻書 juan 2 in Wang Song 王崧, Ed., Yunnan Beizhengzhi, p. 111.

57 Hou Yunqin, Xianfeng Dengchuan Zhou Zhi, juan 15, p. 1.

58 "Xixinquan Bei 洗心泉碑 (Spring for Washing Hearts Stele)", in Zhao Min and Wang Wei, Eds., Dali Eryuan Beike Jilu, p. 24.

59 Cheng Jinren, Ed., Qianlong Zhaozhou Zhi 乾隆趙州志, juan 1 Minsu 民俗, p. 28.

60 Wang Mingke 王明珂, “Wang Song de Difangzhi Shijie: Ming Qing Shiqi Yunnan Difangzhi de Wenti Yu Qingjing", pp. 97-118.

61 “Biaoleng Si tian Ji 標楞寺田記 (A Record of Wet-fields Belonging to the Biaoleng Temple)", in Zhao Min and Wang Wei, Eds., Dali Eryuan Beike Jilu, p. 40.

62 Zhao Gongxiu, Ed., Kangxi Langqiong Zhou Zhi, juan 7, p. 21.

63 "Changle Shen Shanggou Beiji 長樂神上溝碑記 (Stele Record of the Upper Ditch of Changle Village God)", in Zhao Min and Wang Wei, Eds., Dali Eryuan Beike Jilu, p. 204.

64 “Lanruo Si Changzhu Bei 蘭若寺長住碑 (Stele on Land-holdings of Lanruo Temple)" in Zhao Min and Wang Wei, Eds., Dali Eryuan Xian Beike Jilu, p. 72.

65 “Zeyuan Liuchang Bei (干橋水利) 澤遠流長碑 (Stele on the Irrigation System of Ganqiao Village)", in Zhao Min and Wang Wei, Eds., Dali Eryuan Xian Beike Jilu, p. 92.

66 “Zhao Tianzi Miao Bei 趙天子廟碑 (Zhao Tianzi Temple Stele)", in Zhao Min and Wang Wei, Eds., Dali Eryuan Xian Beike Jilu, p. 168. 
67 “Dongchuan Da Miao Bei 東川大廟碑 (Stele of the Dongchuan Great Temple)”, in Zhao Min and Wang Wei, Eds., Dali Eryuan Xian Beike Jilu, pp. 132-133.

68 “Daoguang Jiachen Nian Bei 道光甲辰年碑 (Inscription on Madam Hou's Virtue in 1844)", in Zhao Min and Wang Wei, Eds., Dali Eryuan Xian Beike Jilu, pp. 112.

69 Eryuan Xianzhi Bianweihui, Ed., Eryuan Xianzhi, p. 55.

70 Jianxiong Ma 馬健雄, “Shiye Kuanggong Yu Difang Junshi hua”, pp. 88-113.

71 John E. Herman, Amid the Clouds and Mist.

\section{Bibliography}

Ai Zixiu 艾自修, Compiler. Chongzhen Dengchuan Zhou Zhi 崇禎重修鄧川州志. Dali: Dali Zhou Wenhua Ju Reprint, 1983.

Cheng Jinren 程近仁, Ed. Qianlong Zhaozhou Zhi 乾隆趙州志. In Zhongguo Difangzhi Jicheng: Yunnan Fuxian Zhi Ji 77中國地方志集成: 雲南府縣志輯 77. Nanjing: Fenghuang Chubanshe, 2009, juan 1 minsu 民俗, p. 28.

Ch'u T'ung-tsu. Local Government in China under the Ching. Harvard: East Asia Center of Harvard University, 1965.

Daniels, Christian. "Historical Memories of a Chinese Adventurer in a Tay Chronicle; Usurpation of the Throne of a Tay Polity in Yunnan, 1573-1584". International Journal of Asian Studies, Vol. 3 (2006), pp. 21-48.

Elvin, Mark, Darren Crook, Shen Ji, Richard Jones and John Dearing. "The Impact of Clearance and Irrigation on the Environment in the Lake Erhai Catchment from the Ninth to the Nineteenth Century". East Asian History, Vol. 23 (2002), pp. 1-60.

Eryuan Xianzhi Bianweihui 洱源縣志編委會, Ed. Eryuan Xianzhi 洱源縣志. Kunming: Yunnan Renmin Chubanshe, 1991.

Fan Chuo 樊綽. Manshu 蠻書. Taibei: Dingwen Shuju, 1972. (楊家駱主編 國學名著珍 本彙刊 史學彙刊之一).

Grove, Linda and Christian Daniels, Eds. State and Society in China: Japanese perspective on Ming-Qing Social and Economic History. Tokyo: University of Tokyo Press, 1984.

Herman, John E. Amid the Clouds and Mist: China's Colonisation of Guizhou, 1200-1700. Cambridge and London: Harvard University Asia Center, 2007.

Hou Yunqin 侯允欽, Compiler. Xianfeng Dengchuan Zhou Zhi 咸豐鄧川州志. Taipei: Chengwen Press, 1968.

Hucker, Charles O. A Dictionary of Official Titles in Imperial China. Taipei, Southern Material Center Inc., 1985.

Li Xiaoyou 李孝友 and Xu Wende 徐文德. Diankao Jiaozhu 滇考校注. Kunming: Yunnan Minzu Chubanshe, 2002.

Ma Jianxiong. "Zhaozhou Bazi Society in Yunnan: Historical Process in the Bazi Basin Environmental System during the Ming Period (1368-1643)". In Ts'ui-jung Liu, Ed., Environmental History in East Asia: Interdisciplinary Perspectives. London: Routledge, 2014, pp. 131-155.

Jianxiong Ma 馬健雄. “Shiye Kuanggong Yu Difang Junshi hua: Qing Zhongqi Yunnan Nanxibu Yinkuangye Shuaitui Yu Huimin De Zuqun Dongyuan 失业矿工与地方军事 化: 清中期云南西部银矿业衰退与回民的族群动员 (Unemployed Miners and Local Militarisation: Ethnic Mobilisation of the Hui and the Decline of Silver Mining in the Mid-Qing)”. In Yao Jide 姚繼德 and Ma Jianxiong 馬健雄, Eds., Yisilan Yu Zhongguo Xinan Bianjiang Shehui 伊斯兰与中国西南边疆社会 (Islam and the Southwest Frontier of China). Kunming: Yunnan Daxue Chubanshe, 2017, pp. 88-113.

Ni Tui 倪蜕. Dianyun Linian Zhuan 滇雲歷年傳. Kunming: Yunnan Daxue Chubanshe, 1992. 
Tagliacozzo, Eric and Wen-Chin Chang, Eds. Chinese Circulations and Networks in Southeast Asia. Durham, NC: Duke University Press, 2011.

Wang Mingke 王明珂. “Wang Song de Difangzhi Shijie: Ming Qing Shiqi Yunnan Difangzhi de Wenben Yu Qingjing 王崧的方志世界:明清時期雲南方志的文本與情 境 (The World of Gazetteer Writing of Wang Song: Text and Context of Local Gazetteers of Yunnan in the Ming and Qing Dynasties)". In Sun Jiang 孫江, Ed., Xin Shixue: Gainian, Wenti, Fangfa 新史学: 概念、文本、方法 (New History: Concepts, Texts and Methods). Beijing: Zhonghua Shujuu, 2018, Vol. 2, pp. 97-118.

Wang Song 王崧, Ed., Yunnan Beizhengzhi 雲南備徵志. Kunming: Yunnan Renmin Chubanshe, 2010.

Watson, James L. "Chinese Kinship Reconsidered: Anthropological Perspectives on Historical Research". China Quarterly, Vol. 92 (1982), pp. 589-622.

Zhao Gongxiu 趙珙秀. Kangxi Langqiong Zhou Zhi 康熙浪穹州志. In Dali Congshu 大 理叢書. Beijing: Minzu Chubanshe, 2007.

Zhao Min 趙敏 and Tik-Sang Liew 廖迪生, Eds. Yun-Gui Gaoyuan De “Bazii Shehui”: Lishi Renleixue Shiye Xia De Xinan Bianjiang 雲貴高原的“壩子社會”: 歷史人類學 視野下的西南邊疆 (Bazi Societies of the Yun-Gui Plateau: Southwest Frontier in the Perspective of Historical Anthropology). Kunming: Yunnan University Press, 2015.

Zhao Min 趙敏 and Wang Wei 王偉, Eds. Dali Eryuan Xian Beike Jilu 大理洱源碑刻集 輯 (A Collection of Inscriptions from Eryuan County, Dali).

Zhou Hang 周沉, Ed. Guangxu Langqiong Xian Zhilue 光緒浪穹縣志. Taipei: Chengwen Press, 1975.

Zhuang Cheng 莊誠. Wanli Zhaozhou Zhi 萬曆趙州志. Hand-copy version held at the Yunnan Provincial Academy of Social Science Library in Kunming. 


\title{
3 The Lancang Guard and the construction of Ming society in northwest Yunnan
}

\author{
Huang Caiwen
}

\section{Introduction}

The Ming garrisoned troops across the empire in military units known as Guards and Battalions (weisuo 衛所, hereafter Guards). Zhu Yuanzhang stationed soldiers at the Guards, allocating each Guard its own military colony land to ensure selfsufficiency in food. In the early Ming, this practice ensured that the soldiers could effectively serve as combat forces in quelling rebellions and controlling ethnic peoples. In addition to serving as military bases, the Guards constituted relatively independent social and cultural units scattered among diverse ethnic populations throughout the empire. In Yunnan, the establishment of Guards over the entire province resulted in the permanent settlement of large numbers of Han military personnel among the indigenous ethnic population. In this manner, the Ming established the basis for the gradual growth of new Han communities in Yunnan from the fifteenth century onwards, markedly altering the ethnoscape of the Mongol-Yuan period. Previous research has concentrated on investigating details of the Guards and the military farming colonies as administrative units and has clarified factual data, such as the number, location, and founding dates of Guards, the types of military personnel assigned to them, the acreage of military farms, and the amounts of grain paid as tax. ${ }^{1}$ This emphasis on administrative organisation has laid a firm foundation for future studies. However, it has also resulted in a bias towards a state-based view of history. In many cases, the Ming established Guards side by side with administrative units in local societies populated with indigenous peoples governed by native officials (tuguan 土官). If we consider history from the viewpoint of local society, a fresh set of questions arises: What changes did the establishment of Guards effect in local society? How did interaction between the military administration and native officials alter the course of local history in Yunnan?

In this chapter, I demonstrate the extent to which the military influenced local society in Yunnan through a case study on the Lancang Guard 瀾滄衛 in northwest Yunnan. The Ming established this Guard in 1395 (Hongwu 28) and abolished it in 1687 (Kangxi 26). Located in Beisheng sub-prefecture 北勝州 (today’s Yongsheng county 永勝縣), for nearly 300 years the soldiers of this Guard played a vital role in protecting communication routes in northwest Yunnan, administrating the territory under native official (tuguan 土官) jurisdiction in the 
mid- and upper courses of the Jinsha River 金沙江, and maintaining order and peace in the region. Its strategic position on communication routes leading to Sichuan enabled the Lancang Guard to superintend native officials located to the northwest in Lijiang 麗江 and Yongning 永寧, whose territory adjoined Tibet. The geopolitical position and the relatively complex nature of ethnic relations in the basins and in the mountains provide rich source material for investigating the changes wrought on local society by the establishment of a military institution such as the Guards among an indigenous population. To understand the establishment of the Guard in a broad context, I commence this chapter with a description of northwest Yunnan's topography and brief histories of five native officials who administered it. I trace in detail the rise and the decline of the Lancang Guard, describing the breadth of its administrative organs, and argue that infrastructure constructed by the Guard, such as schools, irrigation facilities and market systems, benefitted local society. Finally, I describe the creation of a new ethnic identity among soldiers who served the local native official after the sixteenth century to illustrate the impact of the military on the ethnoscape.

\section{Location of Beisheng and the native officials in northwest Yunnan}

Maintaining stability on the borders has always been a prime concern of the Chinese dynastic state. Situated in Southwest China, Yunnan adjoins mainland Southeast Asia in the south and Tibet in the northwest. From ancient times, overland routes have connected Yunnan with Myanmar and India as well as other provinces, such as Sichuan and Guizhou. Successive dynasties since the Qin and Han periods have attached substantial importance to opening and maintaining communication routes leading to the outside world through Yunnan. The early Ming state quickly realised the strategic importance of thoroughfares in Yunnan. Therefore, in addition to establishing numerous Guards, it also followed the Mongol-Yuan system of establishing postal relay stations (yizhan 驛站). For instance, in 1387, the Ming constructed one fort (bao 堡) every $60 \mathrm{li}$ 里 along the route from Yongning to Dali, allocating to each fort military farming colonies (juntun 軍屯) with wet fields to provide food and ordering the soldiers to "send messages back and forth as a substitute for postal transmission" (yichuan 驛傳). ${ }^{2}$ The establishment of military forts with the same responsibilities as postal relay stations for transmitting messages along the main communication arteries strengthened state control over Yunnan.

\section{Position of Beisheng on the communication route to Sichuan}

Beisheng was located in today's Yongsheng county. The name changed throughout the ages, occasionally even multiple times during the same dynasty. ${ }^{3}$ After submission to Mongol-Yuan suzerainty, the court established Shizhou 施州 in this location in 1278 and renamed it Beisheng sub-prefecture in 1280 before upgrading it to Beisheng prefecture 北勝府 in 1287 (see Map 3.1). The Ming downgraded the prefecture to a sub-prefecture (zhou 州) under the jurisdiction of the Provincial 


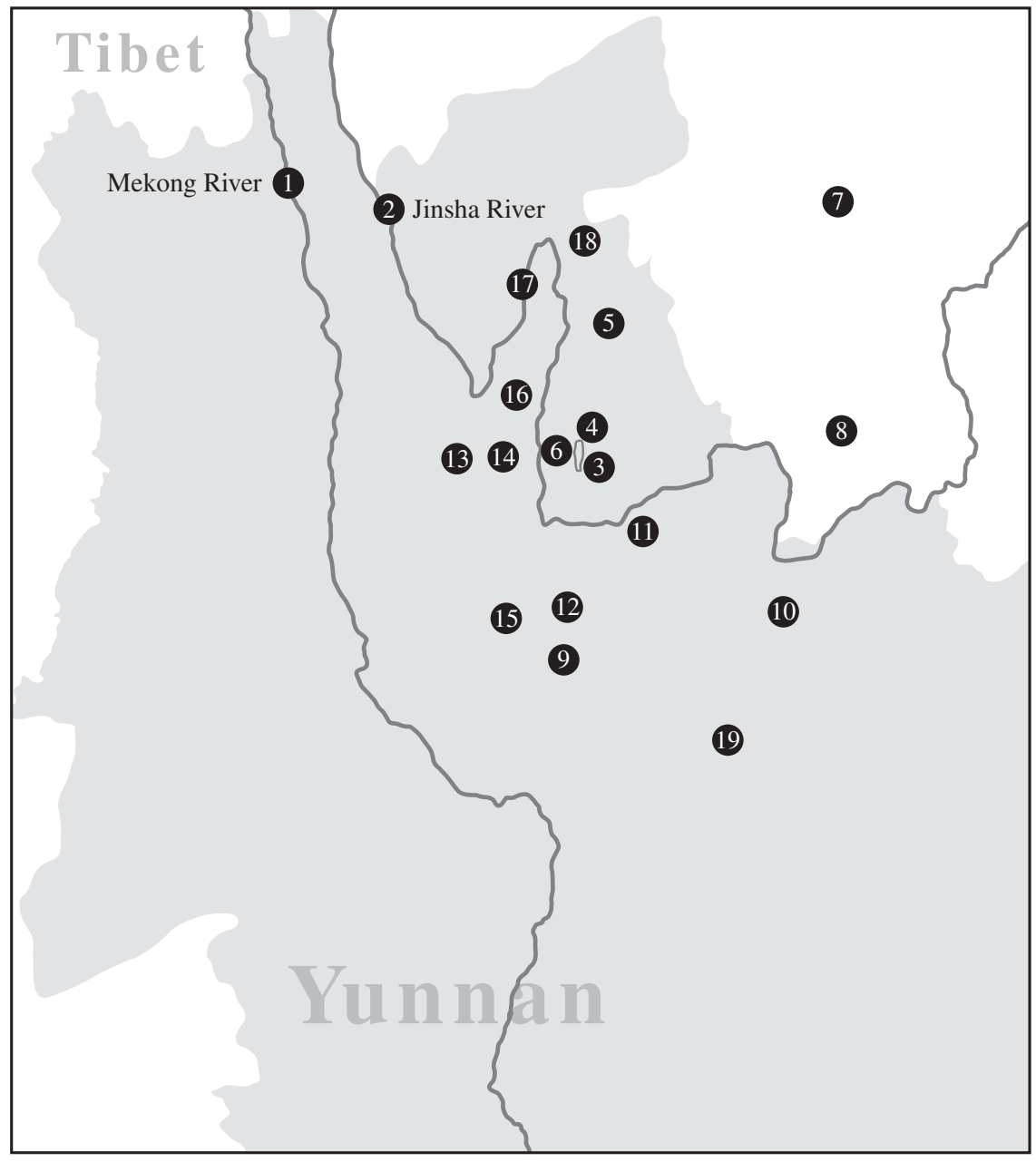

(1) Mekong River 瀾滄江

8 Huichuan 會川

(15) Dali 大理

(2) Jinsha River 金沙江

(9) Yunnan (Xiangyun) 雲南/祥雲

16 Lijiang 麗江

(3) Lake Chenghai 程海湖

(10) Yuanmou 元謀

(17) Baoshan 寶山州

(4) Lancang Guard (Beisheng zhou) 瀾滄衛/ 北勝州

(5) Langqu 蒗真州

(11) Iron Chain Gorge 鐵索箐

18 Yongning 永寧

(12) Daluo Guard (Binchuan)

(19) Chuxiong 楚雄

6) Shunzhou 順州 大羅衛/賓川

(7) Jianchang 建昌

13 Jianchuan 劍川

(14) Heqing 鶴慶

Map 3.1 Northwest Yunnan, c.1582. 
Administration Commission (Buzhengsi 布政司) and subordinated it to Heqing prefecture 鶴慶府 during the third lunar month of $1382 .{ }^{4}$ With the appointment of a rotating official as magistrate of Beisheng sub-prefecture in 1384, the region became jointly administered by an imperial and a native official. In 1396, the year following the founding of the Lancang Guard, the Ming placed the region under military administration, naming it the Military-cum-Civilian Military Command of the Lancang Guard 瀾滄衛軍民指揮使司, subsequently upgrading it to Beisheng Directly Attached sub-prefecture 北勝直隸州 in 1441. The region remained a directly attached sub-prefecture for over 250 years until 1692 (Kangxi 31), when the Qing upgraded it to Beisheng prefecture 北勝府. It was downgraded to Yongbei directly attached sub-prefecture 永北直隸州 in 1767 (Qianlong 32) and to Yongbei county 永北縣 in 1913 before being named Yongsheng county in 1933.

The Ming Shi described Beisheng sub-prefecture as situated in the area where Yunnan met Sichuan:

Located northeast of Dali, and adjoining the Lama 喇嘛 and Tubo 吐蕃, it linked with Lijiang and Heqing inside the province. The physical terrain was precipitous and inaccessible. It had a high-altitude alpine climate. ${ }^{5}$

The land lies high in the northeast and low in the southwest, and settlements formed in the mountain basins (bazi 壩子) of Sanchuan 三川, Chenghai 程海, Qina 期納, Taoyuan 濤源 and Pianjiao 片角. The Jinsha River runs south before turning east to flow out of the province. The Jingtai period (1450-1456) gazetteer of Yunnan described Beisheng sub-prefecture as surrounded by the Jinsha River and "secured by three passes on the west, south and north" such that the topography ensured that “even if barbarians from outside (waiyi 外夷) come close to the boundaries, they do not dare to cross the boundary, so there is no fear of bandits and robbers". ${ }^{6}$ Beisheng occupied an important position on the tea horse trade road between Sichuan and Tibet from the Tang dynasty onwards. Travelling north, merchants could enter Tibet via Lijiang. Journeying east, they could enter Sichuan and reach Chengdu. Moving south, travellers had direct access to Chuxiong and Kunming, and turning west, they could reach Myanmar and India via Dali and Baoshan. Beisheng sub-prefecture covered a vast area and included an important thoroughfare on the trunk line of the tea horse trade between Yunnan, Sichuan and Tibet in the early Ming. Its location was strategically vital for controlling the Tibetans (Tubo 吐蕃) to the north. The Qianlong gazetteer of Yongbei prefecture states, "linked with Binchuan 賓川 and Dengzhou 鄧州 to the south and facing the barbarian peoples (fanyi 番彝) to the north, it served as a fence of protection for Dali, and as a place from which to restrain (yinkong 引控) various native officials"?

\section{Native officials in northwest Yunnan during early Ming}

There were numerous leaders of ethnic peoples in northwest Yunnan during the late Yuan and early Ming periods. The dominant native official families in the Ming included the Gao 高 and Zhang 章 of Beisheng sub-prefecture, the $\mathrm{Mu}$ 木 
of Lijiang prefecture, the A 阿 of Yongning sub-prefecture, the A 阿 of Langqu sub-prefecture 蒗莧州 and the Zi 子 of Shunzhou 順州.

The Gao of Beisheng claimed descent from Gao Shengtai 高昇泰, who usurped the throne of the Dali kingdom c.1094 for approximately one year. According to the Yuan History, Gao Zhisheng 高智升 sent his grandson, Gao Dahui 高大惠, to administer the area after the fall of the Nanzhao kingdom. ${ }^{8}$ The Gao served as the Native Officials of Beisheng sub-prefecture for eleven generations during the Ming dynasty. The Ming appointed the first Gao Ce 高策 in recognition of his meritorious military service in 1389, and the eleventh Gao Shichang 高世昌 inherited the position of Vice Magistrate of rank four in 1630. The Gao administered a broad area that extended for 300 li to Mala Chief's Office 馬喇長官司 in the east, where it bordered with Sichuan; for 270 li to Iron Chain Gorge (Tiesuo qing 鐵鎖箐) in the south, where it adjoined Binchuan sub-prefecture 賓川州; for 70 li to Gezaolang 革早郎 in the west, where it conjoined with the territory of the Zi Native Official; and for 5 li to Laoya Gorge 老鸦箐 in the north, where it touched the territory of the Zhang Native Official. ${ }^{9}$

After Mu Ying 沐英 conquered Dali, Zhang Ji Tie Mu Er 章吉帖木儿, the Native Magistrate of Beisheng, pledged alliance to the Ming in 1382. Later, $\mathrm{Mu}$ Ying ordered his son, Guanyin $\mathrm{Nu}$ 觀音奴, to participate in the military campaigns against the armed revolts in locations such as Sanying 三營 and Puyan 普彦. However, his soldiers deserted. For this failure, the Ming demoted the Zhang to the position of Vice Magistrate 州同 and forced them to reside at the sub-prefectural seat 州治 to assist the Gao Native Official. The Zhang family served in this post for fourteen generations during the Ming period. The area that the Zhang administered extended for $300 \mathrm{li}$ to the Chief's Offices in Sichuan to the east; for $15 \mathrm{li}$ to the territory of the Gao Native Official in the south; for $10 \mathrm{li}$ to the boundary with the Han people at Longtan 龍潭 in the west; and for $120 \mathrm{li}$ to the river boundary at Langqu postal relay station 蒗薬站 in the north.

During the Ming dynasty, the Mu Native Official of Lijiang was the most powerful and influential native official in northwest Yunnan. Lijiang prefecture exercised jurisdiction over four sub-prefectures (Lanzhou 蘭州, Tong'an 通安, Jujin 巨津 and Baoshan 寶山) and one county (臨西縣) in the early Ming. The $\mathrm{Mu}$ were one of the three most powerful Native Officials in the province, the other two being the Tao 陶氏 family of Jingdong 景東 and the Na family 那氏 of Yuanjiang 元江. When Fu Youde 傅友德 captured Dali in the spring of 1382, A Jia A De 阿甲阿得, Vice Pacification Commissioner 宣撫司副使 of Lijiang under the Mongol-Yuan, pledged alliance to the Ming. Zhu Yuanzhang bestowed the surname $\mathrm{Mu}$ on him to show his appreciation for his "leading his people to submit early, setting an example for other indigenous peoples" and for "clearly displaying sincerity". ${ }^{10}$ The Ming established Lijiang prefecture in 1383 and appointed $\mathrm{Mu}$ De 木得 Prefect in the following year. The Mu served as Native Officials under the Ming for fourteen generations.

The $\mathrm{Mu}$ administered an expansive area. It extended for $180 \mathrm{li}$ to Langqu sub-prefecture under the jurisdiction of the Lancang Guard in the east and had the Jinsha River as its border; for $70 \mathrm{li}$ to Heqing Military-cum-Civilian 
prefecture 鶴慶軍民府 in the south; for 200 li to the Lancang River in the Xifan 西番 (today's Pumi 普米 ethnic group) territory in the west; for $320 l i$ to the Gedian Chief's Office 革甸長官司 in Yongning prefecture in the north; for $270 \mathrm{li}$ to Yongning prefecture in the northeast; for 200 li to the Military-cum-Civilian Military Command of the Lancang Guard in the southeast; for 130 li to Jianchuan 劍川 in the southwest; and for 350 li to the border with the Xifan 西 番 in the northwest. The four sub-prefectures under Lijiang's jurisdiction all fell within this area. ${ }^{11}$ During the late Ming, Mu Native Officials expanded their sphere of influence with military force. Their area of control subsequently extended as far as the Yalong River to the northeast and the N'mai Hka (Nam Tamai) River 恩梅開江 in northwestern Myanmar in the west, thus enabling them to control vital communication lines between Yunnan, Sichuan and Tibet.

The A family of Yongning also benefitted from early submission to the Ming. Their ancestor Bo Dou Ge Ji 卜都各吉, the Native Official of Yongning during the Mongol-Yuan period, led his people to submit in 1381. As a result, the Ming appointed him Magistrate of Yongning sub-prefecture, at the time subordinate to Heqing prefecture. Yongning sub-prefecture came under the jurisdiction of the Lancang Guard in 1396, and a total of thirteen A family males served as Native Officials during the Ming period.

As Native Officials, the A administered an area contiguous with Sichuan that extended for $60 l i$ to the Native Battalion Commander 土千户 at Zuosuo 左所 in Yanyuan county 鹽源縣 in the east; for 170 li to Kaxipo 卡洗坡 in the south, bordering with the territory of the Langqu Native Official; for 80 li to Bojiao 卜脚 in the north, having the river as the boundary with Lijiang prefecture; and for 300 li to Gufan 古蕃 in the west.

The Zi, an old family of leaders whose ancestors hailed from Niu Dan 牛賧, served as the Native Magistrate of Shunzhou 順州土知州 for eleven generations during the Ming. The Mongol-Yuan founded Shunzhou after the submission of $\mathrm{Zi} \mathrm{Ri}$ 子日 and appointed him Native Magistrate. Zi Yu 子輿 submitted in 1382, and although the Ming appointed a regular magistrate to administer Shunzhou, $\mathrm{Zi} \mathrm{Yu}$ inherited the title of Native Magistrate. The Zi Native Official administered an area that extended for $40 l i$ to the Baqing River壩箐河 in the east, adjoining the territory of the Gao; for 40 li to Maidi Po 麦地坡 in the south, flanking the territory of the Gao in Heqing prefecture; for $60 l i$ to Jingli 井里 in the west; and for 50 li to Baishui outpost 白水哨 in the north. Both of the latter extensions bordered on the territory of the Mu Native Official of Lijiang.

The A family of Langqu sub-prefecture came from Luogong Dan 羅共賧, where their ancestors had served as indigenous leaders (yiqiu 夷酋) for generations. They submitted to the Mongol-Yuan in 1272 (Zhiyuan 9), which resulted in the founding of Langqu sub-prefecture. A De 阿的 submitted to the Ming during the Hongwu period and retained the title of Native Sub-prefectural Magistrate. After his death, his son, A Ji 阿吉, inherited the post in $1386 .{ }^{12}$ The A family served the Ming as Native Officials for eleven generations. The family's jurisdiction extended for 100 li to Genasi 格纳思 in the south and adjoined Zhongsuo 中所 in Sichuan; for 120 li to the Zhan River 站河 in the south to the 


\section{Huang Caiwen}

boundary with the territory of the Zhang Native Official; for $180 \mathrm{li}$ to Jinxing 金行 in the west to the boundary with Lijiang prefecture; and for 120 li to Kaxipo and the boundary with Yongning native prefecture in the north.

The influence of Mongol-Yuan period native official families remained strong in northwest Yunnan during the early Ming. The pedigree of the Gao family dated to Dali kingdom times, and the family members who served as Native Officials after the conquest included Gao Ci 高賜, Native Vice Magistrate of Tong'an sub-prefecture 通安州 in Lijiang Military-cum-Civilian prefecture, and Gao Zhong 高仲 of Heqing Native prefecture. A Nucong 阿奴聪, the Magistrate of Jujin sub-prefecture 巨津州 in Lijiang Military-cum-Civilian prefecture, was another influential family member. Native officials established an extensive network of connections and interest alliances through marriage with other native officials interspersed among the rugged topography and complicated ethnoscape of northwest Yunnan. According to a tomb inscription, intermarriage occurred between five native official families during the Hongzhi and Zhengde reign periods (1488-1521): the Gao of Beisheng, the Mu of Lijiang, the A of Yongning, the Zhang of Beisheng and the Zi of Shunzhou. ${ }^{13}$ Gao Guanyin Ming 高觀音銘, the first wife of Zi Qing 子清, the local Magistrate of Shunzhou, was the daughter of the Gao Native Magistrate of Heqing prefecture from the Hongwu to Xuande era (1382-1436). ${ }^{14}$ According to the Mushi Huanpu 木氏宦譜 (A Genealogical Record of the Official Positions held by Members of the Mu Family), Yanshou Miaoxiang 延壽妙香, the wife of Mu Ding 木定 of Lijiang during the Hongzhi period (1488-1505), was a Beisheng Gao woman. Mu Ding married his daughters to A Chuo 阿綽 of Yongning and Gao Fei 高飛 and Zhang Hong章宏, both of Beisheng. The second sister of Mu Gao 木高 married Gao De 高德, and $\mathrm{Mu}$ Dong木東married Gao Xian 高嫻, a Beisheng Gao woman. Marriage ties created an intricate network of political alliances between native officials in northwest Yunnan. Marriages of convenience consolidated the position of native officials as rulers of their own people and served to expand their spheres of influence.

\section{Revolt by and unrest among ethnic leaders and the Lancang Guard}

The Ming court established Guards in areas of strategic importance long before the conquest of Yunnan in 1364, and their number increased as Zhu Yuanzhang unified the country. The Guards reported to the Regional Military Commission (du zhihui shi si 都指揮使司) within each province, which in turn reported to the Five Military Commissions ( $w u$ jun dudu fu 五軍都督府) at the capital. The two major characteristics of this system included (1) the settlement of soldiers and their families in local areas and (2) the establishment of farming colonies to make the soldiers self-sufficient in food. According to the stipulation of 1374, one Guard consisted of approximately 5,600 soldiers. Every Guard had 5 Battalions 千户所 (i.e., Front, Rear, Central, Left and Right), each with 1,120 soldiers. A Battalion consisted of 10 Companies 百户 of 112 soldiers each. Every Company had 2 platoon commanders 總旗, and 10 men served as squad commanders 小旗. ${ }^{15}$ The Ming followed the Mongol-Yuan in creating Guards in border areas. In essence, 
the Guards integrated military and local administrative systems into geographical contexts, ${ }^{16}$ which aided the maintenance of stability at the borders and exerted positive effects on long-term governance by bringing lasting peace.

Zhu Yuanzhang dispatched $\mathrm{Fu}$ Youde, Lan Yu 蓝玉 and Mu Ying 沐英 with a force of 300,000 soldiers to conqueror Yunnan in the ninth lunar month of 1381. After the pacification of Yunnan during the second lunar month of 1382, the Ming began to form Guards and to garrison troops for defence on a longterm basis. By the mid-Ming period, the state had established Guards in most parts of Yunnan, and according to statistics, the Yunnan Regional Military Commission commanded a total of 131 Battalions, 67 of which lay in west and northwest Yunnan. ${ }^{17}$ The 100,000 plus soldiers settled at the Guards and Battalions throughout Yunnan constituted a vitally important military force for controlling the communication routes in Yunnan.

\section{Revolts by indigenous leaders in the early Ming}

As previously mentioned, numerous native officials with different-sized power bases, each managing their own domain independently, dotted the landscape of northwest Yunnan. After the conquest of 1382, Ming officials reported that "the land has precarious terrain and lies faraway, and their people are wealthy and ferocious". ${ }^{18}$ They described the newly submitted indigenous leaders (tuqiu 土 酋) as "stubbornly wild and extremely crafty by nature" and noted that indigenous leaders "controlled strategic points preventing entry into the mountains". ${ }^{19}$ These leaders frequently revolted, which hindered effective administration of the mountains, and posed substantial threats to stability in Yunnan. The Native Official of Baoshan sub-prefecture 寶山州 in Lijiang and ethnic groups around Songpan 松潘 in Sichuan revolted in the twelfth lunar month of 1384. The Veritable Records of the Ming record that Ming forces sent to quell the rebellion in Songpan captured 120 horses, 300 buffaloes 犏牛 and 590 yaks. ${ }^{20} \mathrm{Ci}$ Mi Ru Ji 刺密如吉, the Native Official of Baoshan sub-prefecture, revolted again in 1385. A Nucong 阿怒聰, the indigenous leader of Jujin sub-prefecture in Lijiang, revolted and attacked Shimen Pass 石門關, resulting in “the Battalion Commander named Pu Quan 浦泉 dying on the battlefield" during the twelfth lunar month of 1386. Later, Lu Chong 陸仲 led a punitive expedition against the rebels and finally "caught and executed" them. ${ }^{21}$

When Yang $\mathrm{Nu}$ 楊奴, the indigenous leader of Jianchuan sub-prefecture, revolted in the tenth lunar month of 1387, Zheng Xiang 鄭祥, the Commander of the Dali Guard, led his troops to suppress him and "killed more than 80 rebels, but Yang Nu managed to escape". ${ }^{22}$ Not long thereafter, Yang Nu revolted again. However, this time, Zheng Xiang killed him, putting an end to the revolt.

Faced with the serious situation of frequent revolts in northwest Yunnan, Zhang Dan 张䋁, the Left Provincial Administration Commissioner of Yunnan, submitted a memorial to the throne during the eighth lunar month of 1391 requesting the stationing of troops. He cited disobedience by the indigenous people in "Yongning, Langqu ... and other Sub-prefectures" as the principal 


\section{Huang Caiwen}

reason. ${ }^{23}$ The court did not approve Zhang Dan's request to establish a Guard in northwest Yunnan. Thus, the indigenous people continued to revolt. $\mathrm{Bu} \mathrm{Ba} \mathrm{Ru}$ Jia 卜八如甲, a leader of the Xifan (Pumi 普米 ethnic group), and Cita 刺塔, the headman at Tuoyushui Fort 拓榆水寨, rose in revolt in the ninth lunar month of 1392, attacking Langqu from Yongning. Jia Hala 贾哈喇, the indigenous leader of the Mosuo Grottoe 摩㱔洞 in Yongning, revolted in the twelfth month of 1393, and he "plundered Jianchang 建昌, and laid siege to the fort at Hexi 河西" during the first lunar month of $1394 .{ }^{24}$ Ming forces did not quell this revolt until 1398, when they "captured Jia Hala, and sent him to the capital where he was executed". ${ }^{25}$ In the twelfth lunar month of 1396, "the indigenous bandit, Bu bai Ru Jia 卜百如加 robbed and killed soldiers and civilians” in Yongning. ${ }^{26}$ The frequent revolts in northwest Yunnan created a sense of crisis, which made the Ming court realise it needed to change its strategy to establish firm control. It was the "stubbornness" of the ethnic peoples, their remoteness, and the precarious nature of the terrain that compelled the Ming "to temper threats with mercy". ${ }^{27}$ To ensure long-term stability in the area, the court had to do more than just station troops at Guards and Battalions in Beisheng.

\section{Unrest in the mountain tracts of Iron Chain Gorge}

Resistance in northwest Yunnan sprang from indigenous upland leaders as well as from native officials in the basins (bazi 壩子). Opposition by the leaders of Iron Chain Gorge lasted nearly as long as the dynasty itself. ${ }^{28}$ Iron Chain Gorge referred to large and broad mountain tracts that crossed Binchuan, Zhaozhou 趙州, Beisheng and Yaozhou 姚州 measuring approximately $200 \mathrm{~km}$ in the north-south direction. Iron Chain Gorge lay in the precipitous mountains beside the Yipao River 一泡江 (now known as the Yupao River 渔泡江 in today's Dayao county). Lisuo and other ethnic groups lived scattered over these uplands along a vital communication route: the thoroughfare starting from Sichuan and extending to Dali and Tengchong 騰衝 via Yaozhou. The Ming History records the following:

People at Iron Chain Gorge were of Luo stock 倮種 from the beginning. Relying on the steep mountains, they live by plundering, and harm all the neighbouring prefectures. Some submitted during the Hongzhi era (1488-1505), and [bureaucrats] put them under the jurisdiction of Yao'an and Yaozhou. They came under Yao'an during the Jiajing era (1522-1567). ${ }^{29}$

By the end of the Jiajing era, these raiding activities affected "a vast expanse of 400 plus li”, reaching Huichuan 會川 in Sichuan to the north, Yunnan county (today's Xiangyun 祥雲) in the west, Yuanmou 元謀 in the south and Beisheng in the northwest. ${ }^{30}$ Ethnic groups associated with Iron Chain Gorge resisted the Ming for nearly 200 years. The historical geographer Gu Zuyu 顧祖禹 wrote as follows:

[Iron Chain Gorge] lay in the northwest part of the county and stretched over a great expanse of mountain recesses and streams where brooks and 
paths ran deep and treacherous. Each time the indigenous people gather here, they utilise the precipitous terrain to go in and out and have plundered for over several hundred years. ${ }^{31}$

The plundering not only disrupted safe travel on the thoroughfares between Yunnan and Sichuan but also posed a severe threat to peace and order on the southwest border.

The reach of armed resistance from the centres at Iron Chain Gorge and Red Rock Cliff (Chishiya 赤石崖) expanded during the Hongzhi and Jiajing eras. Li Yuanyang 李元陽, a scholar-official from Dali, described the escalation:

In the beginning, they robbed and plundered merchants, then they torched and captured villages and military colonies (cuntun 村屯), and their brethren have grown by the day. Possessing a penchant for killing people wherever they pass, they run wild doing as they please on the major thoroughfares. ${ }^{32}$

Later, large numbers of heavily armed indigenous people assembled around Iron Chain Gorge and threatened people living in the neighbouring basins, itinerant merchants, and even Ming officials. According to Li Yuanyang,

Half of the province has suffered from the calamities of bandits from the various gorges in Binchuan. Merchants travelling fear them on the roads, and peasants resent them in the fields, and so shouldering their pots and pans, the villagers left with their elderly and young to seek shelter elsewhere. The villages lie abandoned throughout the year. ${ }^{33}$

The court dispatched numerous punitive expeditions against the rebels of Iron Chain Gorge during the decades between 1522 and 1573. However, all ended in failure due to the dense forests in the gorges and limitations on the number of Guard troops that the Ming could mobilise. ${ }^{34}$ Li Yuanyang described the intensification of rebel activity: they "capture the households of scholar-officials and common people, advance on walled cities and rampage everywhere, and no one dares to touch them" ${ }^{35}$ Originally bandits who plundered the countryside, the indigenous people of Iron Chain Gorge now became a force politically opposed to the Ming.

To establish effective control over native officials in the basins and eradicate armed opposition in the uplands of Iron Chain Gorge, the Ming court established the Dali Guard in 1383, the Erhai Guard 洱海衛 in 1386, and the Daluo Guard 大羅衛 in 1494. Officials deployed troops from Zhaozhou, Binchuan and Yaozhou and mobilised troops from the Guards and native officials to surround the uplands of Iron Chain Gorge and Red Rock Cliff. In 1573, after more than 200 years of continuous fighting, Zou Yinglong 鄒應龍, acting on imperial orders, led Ming forces and finally managed to overcome the rebels of Iron Chain Gorge. ${ }^{36}$ Commenting on the aftermath, Gu Zuyu 顧祖禹 wrote, “with seventy-two villages all pacified, the four quarters are stable because troops have been stationed here". ${ }^{37}$ However, the Ming paid a heavy price over many years of fighting before attaining a decisive victory. 


\section{Lancang Guard}

The early Qing scholar Gu Yanwu (顧炎武 1613-1682) noted the strategic importance of Lijiang, Yongning and Beisheng for guarding against Tubo intrusions. ${ }^{38}$ However, the early Ming did not immediately establish defence forces in the northwest after the pacification of Yunnan. Apart from at Dali and Heqing, ${ }^{39}$ the Ming did not establish a Guard along the thoroughfare from Binchuan, ${ }^{40}$ Beisheng, Langqu and Yongning to Lijiang prefecture for over ten years. Thus, the dynasty's military presence remained comparatively weak there. A large number of Mongolian soldiers remained active in western Sichuan, which adjoined northwest Yunnan, after Zhu Yuanzhang unified Yunnan, causing unrest. For instance, Yuelu Tiemuer 月魯帖兒, the Mongolian Commander of the Jianchang Guard 建昌衛, revolted in 1392, and unrest soon spread to today’s Liangshan zhou 凉山州 in Sichuan and much of the surrounding area. Additionally, the Veritable Records reports that "various indigenous peoples rebelled and submitted constantly", ${ }^{41}$ revealing the unstable situation on the border between northwest Yunnan and Sichuan. Western Sichuan lay on the route on which Kublai Khan entered Yunnan in 1253. Therefore, the residual Mongolian army took advantage of the lack of Guards and Battalions in the area to attack, seriously threatening Ming control in Southwest China. The Ming soon realised it was imperative to found Guards in northwest Yunnan to facilitate the safety of communication routes and to monitor and control native officials. The stationing of troops also aided the containment of the armed rebels at Iron Chain Gorge, thereby contributing to the maintenance of stability in the region.

The Ming founded the Lancang Guard by transferring the Yunnan Central Guard 雲南中衛 to Beisheng sub-prefecture in the ninth lunar month of $1395 .{ }^{42}$ The following year, the court converted the sub-prefecture into Lancang Guard Military-cum-Civilian Command 瀾滄衛 軍民指揮使司, an office that administered both military and civilian populations. Wang Zuo 王佐, the Commander, constructed a walled city for the Lancang Guard south of the walled city of Beisheng sub-prefecture. The Qianlong gazetteer of Yongbei prefecture records the size of the Guard city (weicheng 衛城) as follows:

The wall measured five $l i$ 里 3 fen 分 in perimeter and 1.6 zhang 丈 in height, $5 \mathrm{chi}$ 尺 thick at the base, and $1.8 \mathrm{chi}$ thick at the battlements on top. It was surrounded by a moat, and a watchtower [capped] each of the four gates. ${ }^{43}$

In addition to the Guard city's construction, bureaucrats also established many postal relay stations 驛, forts 堡, outposts 哨, and post stations 舖 along the thoroughfares in Beisheng sub-prefecture. They established two postal relay stations in 1396: Lancang postal relay station outside the south gate of the Guard city and Qingshui postal relay station (see Figure 3.1) 60 li south of the Guard city. Later, they established the Jinsha River Fort 金沙江堡 at the Jinjiang Ferry 金江渡口 more than $100 \mathrm{li}$ south of the sub-prefecture, and this location became an important crossing point linking northwest Yunnan with other provinces. 


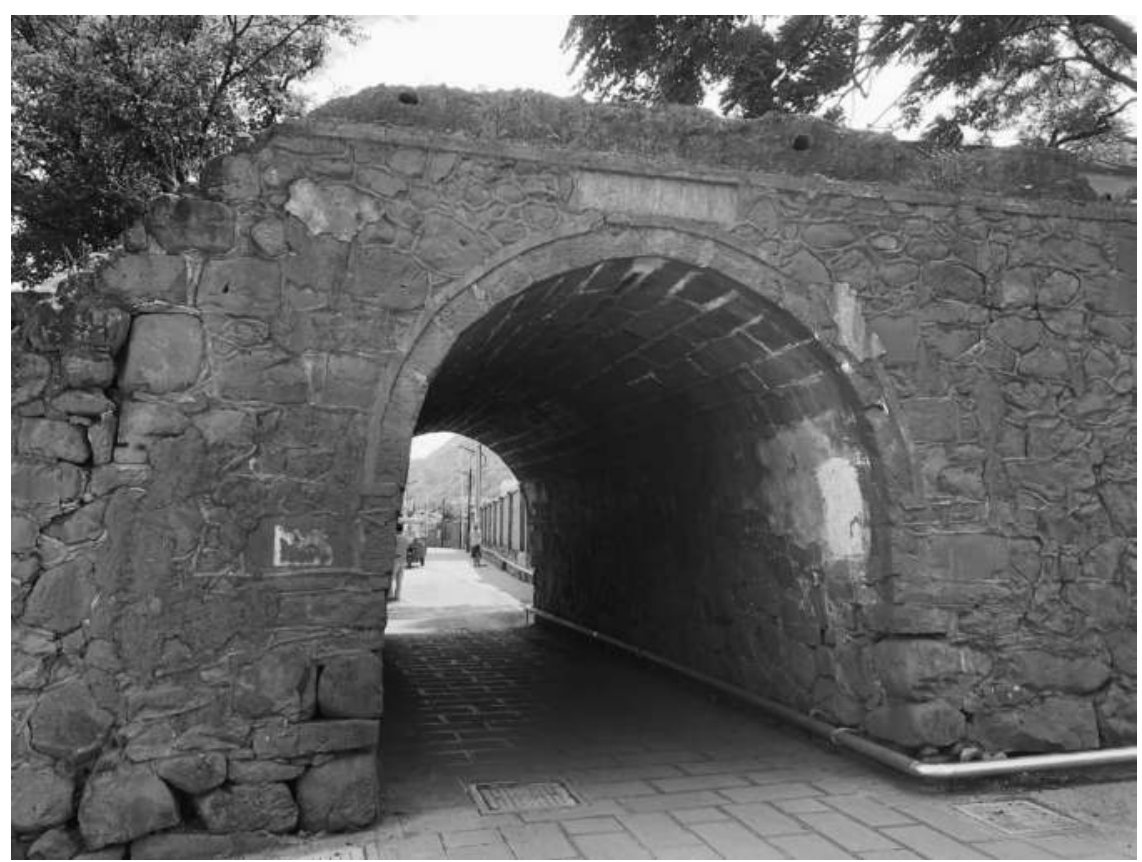

Figure 3.1 The South Gate of the Qingshui postal relay station.

It still stands today in Qingshui village 清水村, Qina township 期納鎮 in Yongsheng county 永勝 縣. Postal relay stations were fortified for protection.

Photograph: Christian Daniels, 23 June 2019.

The three sentry outposts 哨戌 that were established were Huangcao outpost 黃草 哨 (below Nanshan Pass 南山關, $40 \mathrm{li}$ from the sub-prefecture; constructed 1495), Dadan outpost 答旦哨 (150 li south of the sub-prefecture; constructed 1487), and Lizi yuan outpost 李子園哨 (east of the city at Guanyin Gorge 觀音菁, 5 li from the sub-prefecture; constructed 1501). Five post station facilities 舖舍 were established: Zong Pu 總舖 (in front of the sub-prefecture office), Guanlan Pu 觀瀾舖 (15 li south of the sub-prefecture office), Haikou Pu 海口舖 (at Qingshui postal relay station), Luomen Pu 羅門舖 (on the banks of the Jinsha River) and Pianjiao $\mathrm{Pu}$ 片角舖 (at Pianjiao Chuan 片角川, $20 \mathrm{li}$ from Dadan village). ${ }^{44}$ Positioned at strategic points along communication routes under the jurisdiction of the Lancang Guard, postal relay stations, forts and other military institutions ensured the safe passage of military, native officials on tribute-submitting missions, and merchants alike. They played a vital role in strengthening Ming control in northwest Yunnan.

The Ming established twenty Guards and six Independent Battalions 守御千 户所 in Yunnan during the Hongwu era (1382-1397). Of the twenty Guards, only the Lancang, Jinchi 金齒衛 and Tengchong Guards 騰衝衛 were converted to Military-cum-Civilian Commands. This change signalled the advent of 
military governance of civilian populations, which reflected the strategic importance of these three locations for defence. Wang Shixing emphasised this point in his Guangzhi Yi 廣志繹 (author's preface 1597):

The Lancang Guard extending to Yongning and Lijiang in the west controls the Xifan. Jinchi and Tengchong in the south have a grip on the various basins (dian 甸) [of the Tai ethnic group]. Yuanjiang 沅江 and Lin'an in the east safeguard against Jiaozhi 交趾 [Vietnam]. Qujing 曲靖 in the north oversees the Black barbarians (Wuman 烏蠻). Each has been established for a reason. ${ }^{45}$

The foundation of the Lancang Guard not only strengthened military defence. It also enabled co-ordination with the Military Command of the Dali and the Heqing Guards in restraining native officials in northwest Yunnan and maintaining control over the communication routes between Yunnan and Sichuan.

The Military-cum-Civilian Command of the Lancang Guard exercised authority over a comparatively large area at the time of its establishment. In addition to commanding its own Guard troops, it also "controlled Beisheng, Langqu and Yongning Sub-prefectures". ${ }^{46}$ The area under its jurisdiction extended for $400 \mathrm{li}$ to Yaozhou and Dayao counties in Yao'an Military-cum-Civilian prefecture in the east; for 330 li to Dali prefecture, Zhaozhou, and Yunnan county in the south; for 60 li to Heqing Military-cum-Civilian prefecture and to Shunzhou in the west; for 360 li to Yongning prefecture in the north; for 400 li to the Regional Military Commission on Campaign at the Salt Well Guard 行都司鹽 井衛 in Sichuan to the northeast; for 330 li to Yaozhou in the southeast; for 500 li to Dengchuan sub-prefecture in the southwest; and for 150 li to Lijiang Military-cum-Civilian prefecture in the northwest. ${ }^{47}$ The Lancang Guard lost jurisdiction over Yongning and Beisheng sub-prefectures in 1406 (Yongle 4) and 1442, respectively, after which it only administered one sub-prefecture, Langqu. According to the Ming History, "the seat of office shifted to the Lancang Guard City" in 1496, and "shortly later the Military-cum-Civilian office was abolished leaving only the Guard". ${ }^{48}$ Thus, the Military-cum-Civilian Command of the Lancang Guard lost control over civilians and reverted to the sole role of a military institution. The Qing officially abolished the Lancang Guard in 1687, ending its history of nearly 300 years in Yongsheng.

\section{Interaction between the Guard and border society}

After submitting and pledging allegiance to the Ming, native officials in northwest Yunnan gradually came to participate in the construction of a new political order. In the process, they fostered a sustained but complicated collaborative relationship with the Lancang Guard and the Ming court. The establishment of a new order on the northwest Yunnan border and the maintenance of congenial relations between the Ming and the local society were essential for ensuring stability. On the one hand, the Ming had to rely on the Lancang Guard to achieve these goals. It counted on them to restrain the power of native officials, 
to control the armed rebels at Iron Chain Gorge and to manage intricate ethnic relations in the region. On the other hand, native officials also depended on the Lancang Guard to communicate with the Ming. Native officials consolidated their positions and protected their personal interests through the Guard's careful and skilful handling of relations with the Ming court. It was against this background that the military immigrants of the Lancang Guard, the Ming court and all levels of local society created a sustained and collaborative relationship.

\section{Tribute and tax}

The obligation of native officials to submit tribute and pay tax served as an important means for the Ming court to sustain viable lord-vassal relations with native officials. Although native official positions were customarily passed down through bloodlines, succession required formal approval from the court. The Ming History states, "Inheritance must follow the directives of the court, and despite great distance, all [native officials] must visit the capital." ${ }^{\prime 9}$ The Ming established strict regulations for tribute missions that standardised the frequency, the number of attendants in the entourages of native officials, and the required tribute type. Native officials from northwest Yunnan often took advantage of the opportunity afforded by the requirement to "submit tribute once every three years" to present many valuable commodities and local products to the court in the hope of acquiring greater privileges and favours. The court provided native officials with certificates of appointment (gaochi 誥敕), conferred honours on the virtuous and the worthy in their families and adopted various methods of showing appreciation to manage these officials. The Ming designed the tribute system to make native officials more loyal. Native officials, such as the Gao and Zhang of Beisheng sub-prefecture, the $\mathrm{Zi}$ of Shunzhou, and the A of Langqu sub-prefecture, visited the capital several times to present tribute.

Sources document numerous tribute missions. Gao Ying 高瑛, the son of Native Assistant prefecture 土判官 Gao Lin 高琳, presented local products to the court in 1429 and requested imperial approval for the inheritance of his father's title. In 1435, Gao Ying submitted tribute, and the court bestowed paper money (chaobi 鈔幣) on him. ${ }^{50}$ Zhang Guanyin $\mathrm{Nu}$ 章觀音奴, Vice Magistrate of Beisheng sub-prefecture, visited the capital, where he enjoyed an imperial audience and received a certificate of appointment (gaoming 誥命) from the Emperor in 1385 (Hongwu 18). The Native Officials of Shunzhou and Langqu subprefectures journeyed to the capital to submit tribute in 1426, and the Veritable Records record that “The Native Magistrate of Shunzhou, Zi Qing 子清, and his wife, Guanyin Ming 觀音銘, presented horses as tribute" in the summer of that year. ${ }^{51}$ The same source records, “A Ge 阿各 the Native Magistrate of Langqu Sub-prefecture, dispatched Yue Lu 悅魯, the Bashi hou 把事侯, to present horses and local products" $" 52$ in the winter of 1426. After Mu De 木得 pledged allegiance to the Ming and received a hereditary Native Official title, generations of Lijiang native officials submitted tribute at the capital. The Ming History records, “Mu De 木德, the barbarian leader, came to present horses as tribute, 
and [the Emperor] appointed him a magistrate (zhifu 知府) in 1383." ${ }^{53}$ The Veritable Records states, "Mu Chu 木初 and others sent men to present horses as tribute, and the emperor bestowed paper money (chaobi 鈔幣) on them" during the ninth lunar month of 1411 (Yongle 9). ${ }^{54}$ Fourteen years later, in 1425, Mu Chu and others "dispatched another tribute mission to present horses, and received gifts in return from the emperor". ${ }^{55}$ According to the Mushi Huanpu 木氏宦譜, the Mu family sent more than ten tribute missions to the capital during the Ming period.

\section{Deployment of native official troops}

Frequent rebellion by indigenous leaders caused incessant warfare in the border areas of western Yunnan. The Ming court adopted the policy of "using barbarians to control barbarians" (yi yi zhi yi 以夷制夷) and often deployed native official troops to participate in military campaigns. According to the Qianlong gazetteer of Yongbei prefecture, the Ming court ordered the Gao, Zhang and Zi of Beisheng sub-prefecture to join military expeditions on many occasions. Gao Chang 高这 and Zhang Ying 章英 participated in military operations against the Tai polity of Mäng² Maaw ${ }^{2}$ (Ch: Luchuan 麓川) in 1441 and 1443. Gao Lun 高侖 led his troops to suppress the revolts by indigenous leaders at Red Rock Cliff, Tanglang 螳螄 and other locations on three occasions between 1530 and 1554. Gao Chengzu 高承祖 deployed troops to participate in the suppression of the revolts at Iron Chain Gorge in accordance with imperial orders in 1573, and he went again to fight on the southwestern Yunnan border at Tengchong and Longchuan 隴川 in 1583 and 1585, respectively. Acting on orders from the court, Gao Shimao 高世 禁 deployed his troops to Menghua, Kunbang 困蚌, Manla 蠻臘, Dingjia 定嘉, Shunning 順寧, Wuding 武定 and Tengchong between 1597 and 1610. Similarly, Gao Shichang 高世昌 led soldiers to lay siege to rebel villages in Zhanyi subprefecture 沾益州 in 1622, and Zhang Peng 章鵬 dispatched troops for a punitive expedition against rebels in Lufeng 祿豐, Wuding and Xundian 尋甸 in 1528.

The court even requisitioned troops from the $\mathrm{Zi}$ family, which possessed fewer resources than the Gao. Zi Ying, the Native Vice Magistrate of Shunzhou, fought at Guduma 古都麻 and other villages in Binchuan in 1490. Zi Tong 子潼 led soldiers to suppress the revolts by An Quan 安銓 and Feng Wen 鳳文 in Wuding prefecture in 1527. Zi Mingshao 子鳴韶 rendered meritorious service in the campaign against $\mathrm{Na}$ Jian 那鑒, the indigenous leader of Yuanjiang prefecture, in 1552. Subsequently, Zi Yilong 子一龍 and Zi Tianxi 子天錫 successively dispatched troops to quell rebellions in Ami sub-prefecture 阿迷州 and Dali until the Chongzhen era (1628-1644). ${ }^{56}$

The Ming relied on the Mu family of Lijiang to pacify disturbances on numerous occasions. The $\mathrm{Mu}$ deployed troops in campaigns against revolts by Yang $\mathrm{Nu}$ (Native Magistrate of Jianchuan), Bu Ba Ru Jia (indigenous leader of Yongning), Jia Hala 賈哈刺 (Native Official at the Zuosuo Salt Well Guard in Sichuan), and against Mäng ${ }^{2} \mathrm{Maaw}^{2} .^{57} \mathrm{Mu}$ De joined the expedition against A Nucong, the indigenous leader of Jujin sub-prefecture, in 1386 and participated with Mu Ying 沐英 in the defence of Jingdong and Dingbian 定邊. 
The Ming History records that $\mathrm{Mu}$ De "was given a hereditary title for meritorious services on all" the campaigns. ${ }^{58}$ The $\mathrm{Mu}$ family played a highly important role in "controlling the Tibetans (Tubo 吐蕃) and warding off the Western barbarians" (Xirong 西戎) even though the Ming had never stationed troops or established a Guard in Lijiang.

To arouse enthusiasm among native officials to participate in military campaigns, the Ming court adopted the performance of the soldiers of the native officials on the battlefield as a benchmark for succession and promotion. Sources document many examples. For instance, the court honoured Gao Cong 高聰 of Beisheng sub-prefecture with the prestigious title Grand Master for Governance 奉政大夫 and bestowed an imperial commendation (gaoming 誥命) on Gao Lun, promoting him to the fourth rank 四品散官 with the title of Grand Master 大夫之職 in appreciation for his outstanding service. The court presented Gao Chengzu with a horizontal board inscribed with the words "Serving the Country with Loyalty" 報國忠 貞 and honoured Zhang Guanyin Hai 章觀音海with an imperial commendation and an honourable title. Officials presented $\mathrm{Zi}$ Ying, the Native Vice Magistrate of Shunzhou, with a flowery red silver tablet (huahong yinpai 花紅銀牌) for meritorious service. ${ }^{59}$ According to the Mushi Huanpu, the Emperor conferred the prestigious title of Grand Master Exemplar 中憲大夫 on Mu De 木得 posthumously and honoured his wife with the title of Respectful Lady 恭人. The court bestowed a Sincerity in Serving the Country 誠心報國 gold belt on $\mathrm{Mu}$ Chu and awarded him the prestigious title of Grand Master Exemplar and posthumous titles.

To curb the power of native officials, the Ming took advantage of disputes within native official families, deploying other native officials to solve them. This strategy was undoubtedly adopted when Gao Shichang 高世昌 succeeded his deceased half-brother Gao Shimao as Native Magistrate of Beisheng subprefecture in 1620. Shichang's nephew Gao Lan 高蘭 set fire to his uncle's house, killing more than seventy family members. Shichang's uncle, Mu Zeng 木增, the Native Official of Lijiang prefecture, volunteered to personally lead his soldiers to crush Gao Lan when he learnt of the tragedy. The Ming History records the dispatch of Mu Zeng:

Senior officials praised his righteousness, and deployed Zeng to lead his troops to quell [the disturbance]. [Zeng] captured and beheaded Gao Lan, impaling his head on a pole for public display. ${ }^{60}$

Native officials in northwest Yunnan took advantage of the Guard system to strengthen their links with the Ming state. They forged connections with military officers in the Guards through marriage unions to protect their vested interests. For instance, Gao Chengzu, Native Official of Beisheng sub-prefecture, married his third daughter to Li Junzhi 李君植, Associate Military Commander 指挥同 知 at the Lancang Guard during the Wanli era (1573-1619). Chengzu's wife was the third sister of Mu Wang 木旺, the Native Official of Lijiang. ${ }^{61}$ Here, we can discern a pattern of native officials extending marriage alliances to include military officials of the Lancang Guard. 


\section{Huang Caiwen}

In summary, numerous tribute missions to the capital, the deployment of troops to fight for the Ming, and the issue of rewards from the emperor further strengthened interaction between the native officials in northwest Yunnan, the Ming court, and local administrative units at every level.

\section{Appointment of a Military Defence Vice-Commissioner}

The Ming severely punished military officers in the Guards and rotating officials for negligence of duty. The Veritable Records record an incident related to military discipline that had repercussions for military administration. In the tenth lunar month of 1497, “Zhang $\mathrm{Ni}$ 章輗, the tushe of Beisheng sub-prefecture, gathered a group of barbarian bandits (fanzei 番贼), and crossing the boundary killed more than 150 indigenous people (yimin 夷人) at Daobing fortified village 刀丙寨.” Investigating officials arrested Lu Song 陸嵩 and Qin Tie 秦鐵 from the Lancang Guard and Zhu Guang 朱廣, the Magistrate of Beisheng subprefecture. The Ministry of War charged them with "the crime of failure to defend 失於防禦之罪”, and ordered them to apprehend the barbarian bandits within the time limit that was prescribed. ${ }^{62}$ This incident resulted in the appointment of a Circuit Intendant 道員 at the Lancang Guard for the purpose of strengthening control over military affairs and handling issues concerning displaced households (liumin 流民). This episode formed the backdrop to the appointment of the Military Defence Vice-Commissioner 兵備副使, who supervised military affairs over a broad area of northwest Yunnan.

A memorial cited in the Veritable Records for the ninth lunar month of 1499 provides more detailed background information. The writer, Li Shao李韶, who was well acquainted with local customs and affairs of Yunnan after having served there as Right Administration Vice-Commissioner, made four important points in his memorial:

The Lancang Guard and Beisheng sub-prefecture are located within the same walled city, and the area [under their jurisdiction] is broad and extensive; it connects with the Xifan 西番 and the Yefan 野番 in Jianchang in Sichuan. In recent years, Zhang Ni, the tushe of the Xifan, and Gao Lian 高 連 granted amnesty to a thousand-plus Yefan 野番 families who relied on the precipitous mountainous terrain [to resist]. Having pledged allegiance, Zhang Ni and Gao Lian, have turned these families into households on their manors (zhuanghu 莊戶). This has made each barbarian obstinate, and murders have occurred. Officials in the sub-prefecture are unable to control the situation because they command no troops. The Guard officials have completely abandoned military administration, and, being indifferent, do not bother to take any action. The six to seven bandit strongholds that lie within the jurisdictions of Yao'an Prefecture, the Daluo Guard and Binchuan, have inflicted great harm on military and civilians. I request that a Military Defence Vice-Commissioner be appointed at the walled city of Lancang 瀾滄城 and that he have jurisdiction over Yao'an Prefecture, the 
Daluo and Erhai Guards, Binchuan Sub-prefecture, and the prefectures of Heqing, Lijiiang, Dali and Jingdong. ${ }^{63}$

The court approved Li Shao's proposal and stationed a Military Defence Vice-Commissioner at the walled city of Lancang to oversee the military affairs of the Lancang Guard.

The writings of the renowned Ming geographer Wang Shixing 王士性 (1547-1598), who served as Military Defence Vice-Commissioner of the Lancang Guard from 1590 to 1592, reveal the breadth of affairs handled by this Guard. Passages in his Guangzhi Yi 廣志繹 provide compelling evidence of the scope of activities undertaken by this Guard. Despite the Guard's great distance from today's northern Myanmar, the war between the Ming and the Toungoo dynasty in 1582-1584 affected the Guards in Yunnan, who dispatched soldiers and were charged with the transportation of provisions. Incursions into southwest Yunnan by the Burmese army created an emergency. Wang Shixing describes the tactics used by troops from Yunnan and mentions the heavy casualties suffered by the Ming army in the harsh climate of today's northern Myanmar during campaigns against the Burmese: "half of the ten thousand soldiers sent from the inland perished due to the heat." ${ }^{\prime 64}$ In addition to the Lancang, other Guards in the province also sent troops.

Located on the official route, the Lancang Guard was responsible for safeguarding foreign envoys on tribute missions to the Ming court. Wang Shixing describes a mission that passed through the Guard in 1592:

The Burmese came with tribute during the renchen 壬辰 year [1592], when I was in Lancang. They brought one tusked elephant, a female elephant, and various sorts of cotton and silk such as foreign cloth (fanbu 番布), Gula brocade 古喇锦 and golden satin damask (jinduan 金段), which all differed from those in China. There was a gold bowl inlaid with smashed pieces of precious stones on its surface, the workmanship was exceptional. ${ }^{65}$

This passage indicates that the Lancang Guard did not merely co-ordinate relations between the Ming court and native officials in northwest Yunnan but also had duties to fulfil in supporting political and military affairs connected with foreign countries. Such matters came under the purview of the Military Defence Vice-Commissioner.

\section{Lancang Guard and social change in local society}

Following the foundation of the Lancang Guard, the Ming established postal relay stations, forts, and outposts (shao 哨) along the communication routes and garrisoned them with sizeable numbers of Han soldiers. These military institutions had two functions. First, they guaranteed safe passage and security along the communication route that linked the Guard with the inland. Second, they facilitated the monitoring of native officials and the suppression of revolts by indigenous leaders, thereby strengthening control over the communication routes 
and the mountain-dwelling ethnic groups. As the backbone of Ming rule in the border areas of northwest Yunnan, the Lancang Guard played a crucial role militarily, economically, culturally and socially in Beisheng sub-prefecture. In this section, I describe the significant influence exerted by the Guard on local society.

\section{Changing the structure of society}

Before the early Ming, northwest Yunnan was mainly populated by non-Han ethnic peoples. Ethnic peoples recorded as residing in mountainous or semimountainous parts of Beisheng sub-prefecture included the Boren 本人, Mosuo man 摩些蠻, Lisuo 栗些, Xifan 西番, Baiman 白蠻, Luoluo 羅羅 and Echang 峨昌. In addition, reportedly, seven ethnic groups, i.e., the Baiman, Luoluo, Mosuo, Dongmen 冬門, Xunding 尋丁 and Echang, were forcibly moved here from the Kunmi River 昆彌河 (today's Miju River 彌苴河 in Dengchuan) by Nanzhao King Yimouxun 異牟尋 (reigned 779-808). ${ }^{66}$

The Jingtai (1450-1456) gazetteer of Yunnan records the ethnic composition of the Lancang Guard as follows: “Han 漢, Bo 來 and Wu people 武人 live among each other near the walled city", ${ }^{67}$ and there are "many Baiyi 百夷 who differ slightly from the Mosuo man within the jurisdiction [of Beisheng sub-prefecture]". ${ }^{68}$ The same gazetteer defined the Lisuo as "another sort of Luoluo, who dwell in mountain forests, and possess no houses". ${ }^{69}$ The Tianqi (1621-1627) gazetteer of Yunnan elaborates: "the indigenous peoples of Lijiang today are collectively known as Mosuo 磨些, and they also dwell in Beisheng, Shunzhou, and Lufeng."70 It also records that the Xifan 西番 "live north of the Jinsha river in Yongning, Beisheng, Langqu". ${ }^{71}$ Beisheng sub-prefecture clearly had a large non-Han population in the early Ming.

After the founding of the Lancang Guard, numerous soldiers, officials, cultured men (wenren 文人) and merchants collectively labelled "Hanren" 漢人 came to Beisheng sub-prefecture. In addition, not a small number of Han officials were banished to the Lancang Guard and forced into military service for misdemeanours. For instance, Zou Lü 鄒律, Assistant Commander of the Yongning Guard 永寧衛 in Guizhou, was demoted and sent to perform military service in perpetuity at the Lancang Guard in the first lunar month of 1508 "because he left his post and returned to his native land for a long time, and due to immoral and disgraceful conduct”. ${ }^{72}$ Similarly, Shang Guanchong 上官崇, the Magistrate of Xuzhou 徐州, was banished to the Lancang Guard in the fourth lunar month of $1510 .^{73}$ The Ming exiled Huo Zhong 霍忠, Assistant Regional Commander of the Left in the East Route of Ningxia 寧夏東路左參 將, “to serve as a soldier in Yunnan's Lancang Guard forever” during the eighth lunar month of 1510. This banishment seems to have been a reduced sentence as Huo Zhong was charged with neglect of duty (shiji 失機), a crime punishable by death. ${ }^{74}$

The surge in Han population and socio-economic growth attracted a number of intellectuals to study in Beisheng sub-prefecture, and certain of them even settled there. For example, Zhou Liangchen 周良臣, a man from Huguang who 
heard that Beisheng had a prodigy named Zhang Zongchu 張宗楚, “travelled 3,000 li to visit him and stayed" during the Zhengde era (1506-1521). ${ }^{75}$ Qian Bangqi 錢邦芑 from Zhenjiang 鎮江 in Jiangnan sojourned at Ruiguang Temple 瑞光寺, located within the jurisdiction of Qingshui postal relay station, for three years during the late Ming. ${ }^{76}$ Many Jiangxi people came to Yunnan to trade in urban areas during the Wanli era. Wang Shixing reports as follows:

When I served in Military Defence at Lancang, fifty to sixty per cent of the population of the entire province of Yunnan came from Fuzhou 撫州. At first, they were traders and only stayed in the walled cities and at markets. $^{77}$

Here, Wang probably refers to the non-military Han population in Yunnan. Later, Jiangxi merchants gradually moved to Beisheng sub-prefecture, and certain of them banded together to extort and cheat local people. The following case recorded by Wang Shixing provides information regarding such a case in Beisheng:

With vast expanses of land and a sparse population, Yunnan would not have seen growth if the Jiangxi merchants did not sojourn, yet they greatly harm the local people. When sentencing a prisoner, I read a document about (A), an elderly man wandering about destitute who was taken in out of pity by (B), a middle-aged man from the same native place. They conducted trade together, and (A) felt happy with his circumstances. One day, (B) encountered (C), a wealthy local person (turen 土人) from whom he desired to make a profit. So (B) and (A) took sundry goods to the house of (C), and the women competed to buy them. Using this as a pretext, (B) started a dispute, and got into a fistfight with (C). On returning home, (B) killed (A) and took [his body] to the home of (C). (B) intimidated (C) by saying that if he paid 200 pieces of gold he would burn the body of (A), thus destroying the evidence [and absolving him of the crime]. If (C) did not pay, (B) threatened to take legal action. Local Bo people ( $t u$ boren 土㗎 人) fear officials by nature, so (C) scraped together all the money in the family and gave (B) 150 pieces of gold. (B) then declared that he would burn the body that night. A relative of $(C)$ was sensible enough to beat the yamen drum and take the case to court. (B) was sentenced to death. From his place of registration, I saw that (B) was from Fuzhou 撫州. ... Serving in Lancang for only two years, I was familiar with their ill practices. I, therefore, did not pay attention to one word of written complaints from Fuzhou migrants. ${ }^{78}$

This passage described an example of Jiangxi traders conniving to harm indigenous people of Beisheng sub-prefecture. It also records how the indigenous people found satisfaction through successful litigation. Wang Shixing mentions that there were many other cases of similar nature, which demonstrates the extent of disruption to the order of local society caused by Han migrants. 


\section{Promoting Confucian education}

To change the customs of indigenous peoples and maintain stability in border societies, Zhu Yuanzhang strongly promoted Confucian education after unification. In the sixth lunar month of 1395 (Hongwu 28), he issued instructions to the Ministry of Rites to establish Confucian schools (ruxue 儒學) to educate promising male offspring of native officials in Yunnan and Sichuan. These schools educated the sons of local ethnic leaders in Confucian rules of behaviour, particularly instilling in them the idea of "righteousness ( $y i$ 義) in the bonds between lord and vassal, and between father and son". The schools emphasised teaching their pupils to understand that fighting and quarrelling with one another violated the principle of propriety ( $l i$ 禮) and to comprehend the unacceptability of such behaviour. Education through Confucianism therefore served as "way of establishing the borders". ${ }^{79}$ The Ming set up Confucian schools in the prefectures and counties across Yunnan, and their establishment in Beisheng subprefecture can be traced to a memorial by Wang Yi 王義, the Magistrate of Shunzhou, submitted to the throne during the second lunar month of 1417:

Though the sub-prefecture is populated by indigenous ethnic peoples (manyi 蠻夷), the people have benefitted from transformation by the sages (shenghua 聖化) over the past thirty-plus years since submission. Language gradually comes to be comprehended at places under the influence of Chinese culture (shengjiao 聲教). There are excellent males among the locals, so I request that we establish a school to educate them in the hope of producing some talented ones. ${ }^{80}$

The court approved the construction of the school. However, education proved difficult due to the comparatively small Han population in Shunzhou. During the seventh lunar month of 1445, Yang Ning 楊寧, Military Consultant for Yunnan and Right Vice-Minister in the Ministry of Justice 參贊雲南軍務刑部右侍郎, suggested shifting the Confucian school from Shunzhou to Beisheng subprefecture on the grounds that the "vulgar customs of the indigenous people" hindered the progress of education at Shunzhou. Yang commented that the larger population at Beisheng sub-prefecture increased the chances of success, and he advocated "appointing officials to teach the students". ${ }^{81}$ After approval from the court, officials established the school in the southwest corner of Lancang Guard city 瀾滄衛城. They constructed a Confucian temple (kongmiao 孔 廟) and a school building 學宮 on a “preliminary scale” 初備規制, ${ }^{82}$ and native officials in Beisheng prefecture and military officers at the Guard sent their children to study there.

State promotion of Confucian education exerted a strong influence on local society in Beisheng sub-prefecture. Li Yuanyang commented, "There have been no emergencies in the jurisdiction since the founding of the Guards, and humanistic learning (renwen 人文) has gradually flourished since the establishment of the school." 83 The civil service examinations enabled a large number of local 
people to become low-level degree holders, and some of them joined the ranks of the gentry, thus creating a local elite that advocated the transformation of society through virtue (dehua 德化). The new elite became an important force for changing common practices in Beisheng sub-prefecture. Let us consider several examples of successful elite members. Tan Sheng 譚昇, from the Lancang Guard, the first provincial degree holder (juren 舉人) in northwest Yunnan, obtained his metropolitan degree (jinshi 進士) in 1466. He served as the Magistrate of Hezhou 合州 in Sichuan and was well known for being incorruptible. Chen Biao 陳表 passed the provincial examinations in 1507 and served as Assistant Prefect of Dongchuan prefecture 東川府, where he was respected for his immaculate conduct. Liu Xi 劉䒽, a tribute student (gongsheng 貢生), served as an assistant instructor in Binchuan sub-prefecture. Discharging his duties efficiently, he was listed as a renowned government official in the Dali area because of his discipline and honesty. ${ }^{84}$ Lü Yuansheng 吕元生, a Battalion Commander in the Lancang Guard, was a filial son. Ruan Jiaxiang 阮嘉祥, from the Qingshui postal relay station, earned his provincial degree in 1615 and served as the Magistrate of Tongchuan zhou 潼川州 in Sichuan. Upright and fair, he raised money and reconstructed the Ruiguang Temple on a site south of the postal relay station after retiring to Qingshui. The temple was considered one of the eight great Buddhist temples of Beisheng sub-prefecture during the Ming dynasty. The Magistrate of Beisheng sub-prefecture bestowed a horizontal board engraved with the words "Virtue and Longevity Returns Gold 德壽換金” on Liu Sishan 劉思善, a government student (xiangsheng 庠生) from Qingshui during the Tianqi period to commend his honesty for not pocketing lost money that he found by coincidence. ${ }^{85}$

Confucian education gradually changed the customs and habits of the indigenous peoples in Beisheng sub-prefecture, particularly their penchant for rivalry. They were positively transformed through "cultural refinement and education" (wenhua jiaohua 文化教化). The Jingtai gazetteer of Yunnan records the following:

Han, Bo and Wu people all live mixed together near the city; they love disputes, and file court cases. Recently, the sub-prefectural school has been shifted [to Lancang Guard City], and they send their children to study the Confucian classics. Having been taught the teachings of propriety ( $l i$ 禮) and righteousness ( $y i$ 義), the students will be transformed to our culture. ${ }^{86}$

The promotion of Confucian education at the Lancang Guard spawned a political and cultural elite loyal to the dynasty and provided its members opportunities to participate in political administration, the management of villages and the promotion of activities for the reform of local customs and habits. A local writer commented, "the mechanism of transformation through guidance (huadao zhi ji 化導 之機) changes customs and habits, and scholars serving as officials benefits the court." ${ }^{\prime 87}$ The new elite contributed positively to the construction of political and cultural order in societies along the communication routes in northwest Yunnan. 


\section{Irrigation projects}

The Lancang Guard adopted the usual ratio of farming to combat soldiers (7:3). The Ming established fifty-three squads ( $w u$ 伍) to open land for cultivation on a large scale in Beisheng sub-prefecture. Thirty-five squads established farming colonies relatively close to the Guard city at Mt. Xiguan 西關山 and in the Sanchuan 三川 and Shunzhou basins. Eighteen squads resided outside Mt. Nanguan 南關山 in the area around Qina and Pianjiao. Place names associated with military farming colonies under the Lancang Guard still remain in Yongsheng county today. ${ }^{88}$ This geographical distribution of military farms had formed by the early years of the sixteenth century. The Zhengde gazetteer of Yunnan reports as follows:

There are fifty Company Commanders within the jurisdiction, and military farms lie scattered among the villages of Qina, Haikou, Mengzhuang dam 盟莊壩 and Pianjiao; they all belong to officers of the Lancang Guard. ${ }^{89}$

The acreage of military farms increased to more than 40,000 $\mathrm{mu}$, of which 6,223.5 $\mathrm{mu}$ belonged to military officers and 35,539.16 $\mathrm{mu}$ belonged to soldiers. ${ }^{90}$ Military farms played an important role in providing grain to feed the troops of the Lancang Guard.

With the expansion in the acreage of land farmed by soldiers, the Lancang Guard initiated irrigation projects. The facilities constructed close to the subprefectural seat included the Guanyin Gorge dam 觀音箐壩 3 li to the east, Mengzhuang dam 35 li to the west, Baojia sluice gate 包家閘 $8 l i$ to the south, Hai sluice gate 海閘 $70 l i$ further to the south, Hecao dam 和草壩 $2 l i$ to the southwest, Changgou dam 長溝壩 $30 l i$ to the north, and Jiulong Embankment 九龍堤 30 li to the northwest. ${ }^{91}$

The construction of these facilities improved irrigation for the wet rice fields of the military and civilians alike. A gazetteer compiled in the Qianlong period records as follows:

Wet fields in the proximity of the City depend on water diverted for irrigation (fenliu guangai 分流灌溉) from Guanyin Gorge, and there is no need to repair [the channels] every year. It has been a practice from former times for soldiers to return to the city during the day and go back to the military farms at night. Senior Agriculturalists (shangnong 上農) have been appointed to inspect in the City, while at each military farm Water Deputies (shuiwei 水委) have been set up to manage the division of the water. ${ }^{92}$

This passage indicates that farms near the fortified city of the Lancang Guard channelled water from Guanyin Gorge for irrigation and that the technique introduced during the Ming period was still used during the Qianlong period (1736-1795). The utilisation and management of water resources strengthened the links between soldiers from the Lancang Guard and the indigenous people of Beisheng sub-prefecture. 


\section{Establishment of market systems}

The Lancang Guard consisted of five Battalions: the Left, the Right, the Central, the Front and the Rear. The Left and the Front Battalions lay in the Sanchuan basin at today's Liangguan and Jinguan. The Right and Central Battalions were located in today's Qina township, while the Rear Battalion encompassed today's Taoyuan 濤源鎮 and Pianjiao 片角鄉 townships. The Ming settled sizeable numbers of Guard soldiers and their families at these places to farm the military colonies. The increase in the outside population and economic growth promoted urban construction and trade at markets in the Lancang Guard. Officials established markets (commonly known as jiezi 街子) in the Guard city and close to the military colonies at the postal relay stations at Qingshui, Qina, Zhongzhou 中洲 and Pianjiao. The 1573 comprehensive gazetteer of Yunnan records that trading at markets across the province followed a similar pattern:

People gather there at noon and disperse at sunset. They use shells 貝 in their transactions. One piece was called a zhuang 莊; four pieces made one shou 手; 4 shou were called miao 苗 and 5 miao would make one suo 索. $^{93}$

On market days, held once every three days at Beisheng during the 1620 s, "all gathered in the sub-prefectural city". ${ }^{94}$ Local people used the twelve animals of the Chinese zodiac, which corresponded to the twelve Earthly Branches 地支, to differentiate between market days at different locations. An eighteenth-century gazetteer records this practice. Market days were named according to the animals of the zodiac. For instance, markets held on rat days (ziri 子日) were termed Rat Day Markets, and those held on bull days were known as Bull Day Markets (chouri \#日) 日) ${ }^{95}$ Markets were held periodically on different days at the Guard city, at the postal relay station at Qingshui and at Qina.

The rise of periodic markets promoted trading activities and the exchange of goods between military personnel in the Lancang Guard and different groups of people in local society. On the prescribed days, people near and far gathered at markets just as spokes converge on a wheel. Such interaction at markets enhanced relations between soldiers and indigenous peoples. Mountain-dwelling indigenous peoples brought timber, cowhides, sheep skins, medicinal items and special foodstuffs and game to the markets to exchange for ironware, food, salt, vegetables and other everyday items. They travelled to the markets via the communication routes controlled by the military. The Qianlong gazetteer of Yongbei prefecture 永北府志 records as follows:

The Xifan 西番 do not have surnames, and they choose their names casually. They practice slash-and-burn agriculture and rely on buckwheat for their livelihood. Both men and women wear clothes made of hemp. They drape felt over their shoulders and carry short knives at their waists. They carry hewn timber and planks on their shoulders to the markets inside the walled cities to sell in order to buy food..$^{96}$ 
This passage describes trading between mountain-dwelling indigenous people and lowlanders. As previously noted, over the long years of administration, the Lancang Guard transformed Beisheng sub-prefecture into a strategic military position for the Ming in northwest Yunnan. In addition, the Guard established local social networks by integrating local market resources, which attracted traders from northwest Yunnan and places as far away as Sichuan and Jiangxi. The Lancang Guard city presented a picture of prosperity, where "shops with an endless array of commodities lined both sides of the street, which thronged with people on market days." 97

\section{Construction of local ethnic status}

The system of Guards and Battalions proved an effective measure for governing the border areas throughout the Ming period. However, a series of changes occurred in the societies along the communication routes in northwest Yunnan after the Xuande era (1425-1435). The expansion of market-exchange networks, the extension of communication lines, and the ascent of local elites loyal to the Ming court exerted a profound impact and gradually weakened the position of the Guards and the Battalions as brokers between native officials and the Ming state. Additionally, increased land sales, intensified oppression of villagers and ill treatment of soldiers by officers of the Lancang Guard caused many soldiers to desert and flee or to abandon military status and gradually blend into local society as civilian households. This series of changes affected the Guards and Battalions and accelerated the "civilianisation" (minhua 民化) of the soldiers. Bullying and humiliation from Lancang Guard soldiers became so intolerable that the local people of Beisheng sub-prefecture appealed to the Ming court in 1442. According to the Veritable Records, the court responded by limiting the power of the Guard to administer civilians, placing the Military-cum-Civilian Command of Beisheng sub-prefecture under the jurisdiction of the Yunnan Provincial Administration Commission, an office responsible for promulgating imperial orders and policies within the province. The adjustment was designed to assuage "the abuse suffered by indigenous people of the sub-prefecture at the hands of the army at the Guard administration". ${ }^{98}$ From the beginning, the Guard had governed the three sub-prefectures of Beisheng, Langqu and Yongning. However, after 1442, it only administered Langqu. As the area of its jurisdiction decreased, the Lancang Guard began to lose its leading role in local society.

No matter whether large or small, native officials in northwest Yunnan maintained their own military forces in the early Ming. The Ming converted Heqing and Lijiang prefectures into Military-cum-Civilian prefectures 軍民府 in the eleventh lunar month of 1397. In his memorial to the throne, Mu Chun 沐春, Marquis of Pacifying the West 西平侯, reported as follows:

The two Prefectures are located in distant places, and many people of the sub-prefectures and counties serve as voluntary soldiers 義兵. Local armies (tujun 土軍) [consist of men who] become soldiers when called to arms, 
and revert to civilian life once relieved from duty, so in the end it is difficult to transfer and assign them to other places. ${ }^{99}$

This memorial demonstrates that "voluntary soldiers" and "local armies" were common in the prefectures, sub-prefectures and counties in northwest Yunnan at the time. The later decline in the importance of the Guards and Battalions resulted in the amplification of the authority of these administrative units. Thus, the bureaucrats came to rely on troops under the command of native officials for ensuring security and maintaining order in local society. The Ming gradually replaced Guard and Battalion soldiers with native official troops as combat forces. A memorial by Yang Ning 楊寧, Military Consultant for Yunnan and Right Vice-Minister in the Ministry of Justice, dated the xinchou 辛丑 day of the twelfth lunar month of 1446 records as follows:

On my visit I learnt that the indigenous people (yiren 夷人) and military auxiliaries (junyu 軍餘) are extremely distressed by the way the guards and battalions in Yunnan force them to construct and repair weapons and travel back and forth for supplies. All guards and battalions have spare land; therefore, I request that we assign $560 \mathrm{mu}$ from the Dali Guard, $200 \mathrm{mu}$ from the Lancang Guard, $300 \mathrm{mu}$ from the Erhai Guard according to the [rule of] simplifying land measurement due to the complexity of the situation ... and assign local army (tujun 土軍) and the yuding 餘丁 ${ }^{100}$ who guard walled cities and relay stations ( $p u$ 舖) to cultivate crops. ${ }^{101}$

Yang Ning's memorial testifies that the local army at the Dali, the Lancang and other Guards participated in the tasks of "guarding walled cities and relay stations" during the Zhengtong era (1436-1449). The Zhengde Yunnan gazetteer records the following:

Indigenous peoples and the Han live among each other in the Yunnan area. Bandits appear and disappear unpredictably, so frontier outposts (shaoshu 哨戍) have been set up to guard every 10 to 30 li along each thoroughfare. ... Officials and the soldiers at each outpost (shao 哨) are stationed together with their families for one year on rotation. There are also civilian outposts (minshao 民哨), which guard the border concurrently with military outposts (junshao 軍哨)..$^{102}$

It is clear that civilian households under the jurisdiction of native officials began participating in defence duties performed by the Guards and the Battalions from the Zhengde era. Previously, in the Zhengtong era, the Ming deployed native officials from northwest Yunnan to participate in the campaigns against the Tai polity of Mäng ${ }^{2} \mathrm{Maaw}^{2}$, in expeditions to suppress revolts at Iron Chain Gorge and in the wars with the Toungoo dynasty. On the one hand, this new practice reveals a slackening in military administration over the Guards and the Battalions across Yunnan, highlighting their unfitness for critical military campaigns. On 
the other hand, it indicates that at the local level native officials possessed strong military forces. These changed circumstances compelled the Ming to depend on native officials and their troops much more than before for safeguarding the borders and for quelling revolts by indigenous leaders from the mid-to-late Ming. This development formed the backdrop for the implementation of the policy known as "assigning the Guards to the administration of sub-prefectures (hua wei gui zhou 劃衛歸州)" in northwest Yunnan in later years, a measure that created conditions conducive to the formation of a new ethnic status.

During the Jiajing and Wanli eras (1522-1620), the Gao Native Official started to strengthen his military power to contend with his adversary in Beisheng sub-prefecture, the Zhang Native Official. To open a thoroughfare to Sichuan through Huaping 華坪, he dispatched the local army (tujun 土軍) and ordered soldiers to settle and guard by cultivating land in the area around Yingpan village 營盤村, situated southeast of the Lancang Guard. He also established postal relay stations. Many years of living among the indigenous peoples in the area resulted in intermarriages and the formation of a unique ethnic group, now known as the Taliu people 他留人.

According to their collective historical memory, the Taliu were the descendants of Han military immigrants who came with $\mathrm{Fu}$ Youde to Beisheng subprefecture during the Hongwu era. These ancestors hailed from locations such as Changsha prefecture 長沙府 in Huguang and Ji'an prefecture 吉安府 in Jiangxi. As soldiers, they participated in the construction of the Lancang Guard city, and the Ming later settled them at Yingpan village on the major communication route between Yunnan and Sichuan. The Taliu came to Yingpan as a squad (wu 伍) consisting of 360 households and constructed the Taliu fort 他留城堡. The Taliu hold a grand ceremony to pay respect to their ancestors on the twenty-fourth day of the sixth lunar month every year and still retain the habit of constructing a simple gate for making offerings to ancestors (jizumen 祭祖門) using 360 pine tree branches to commemorate the households who opened up land here. ${ }^{103}$

The Taliu relate the following story about their ancestors and their formation as an ethnic group. The Gao Native Official of Beisheng required two bronze statues of the Buddha for the reconstruction of Chuandeng Temple 傳燈寺 on Mt. Chicken Foot 雞足山 in Binchuan during the Zhengde era (1506-1521). He dispatched two nuns to carry the statues on their shoulders from Mt. E'mei 峨眉 山 in Sichuan. On the return journey, a serious earthquake shook today's Yingshan village 營山村 in Liude township 六德鄉. One nun died and was buried holding her statue. The other nun continued on her journey home but unfortunately died at Liang'e 良峨 on the eastern shore of Lake Chenghai 程海. When the Gao Native Official challenged the Zhang Native Official for control over the area during the late Ming/early Qing period, he stationed troops at today's Yingshan village. While out on a hunting trip, the Gao Native Official accidentally found the first bronze statue of the Buddha lying on the ground after a flash flood. Thinking that the statue had willingly stayed behind to save all sentient beings, Gao ordered his subordinates to carry it back to the village, and he constructed a temple in its honour. The temple became known as the Dade Temple 
of the Taliu 他留大德寺 and the settlement as Taliu village他留村. ${ }^{104}$ Jiang Qiaosun 江嶠孫, the Magistrate of Yongbei prefecture, established seven charity schools (yixue 義學) in the prefecture in 1734. Yongning prefecture, Langqu zhou, En'e village and Taliu village each had a school for indigenous people (yiguan 夷館). Zhang Lining 張立寧, a Han teacher at the Taliu Charity School, wrote a calligraphy couplet based on the legend related to the bronze Buddha image and the meaning of Taliu and hung it at the entrance to the main hall at Dade Temple. This couplet reflects Taliu collective memory and implies that Confucian teachings and Buddhist culture had influenced them. In the first line of the couplet, Zhang Lining wrote of the Taliu following "a cloudy path of $8,000 l i$ ", indicating that their ancestors had come from a distant place.

Genealogies included in tomb inscriptions provide source materials for tracing the origin of the Taliu's ancestors. All of the inscriptions record that these ancestors came from Changsha prefecture or Ji'an prefecture. In addition, the genealogies repeatedly stress the close association of the Taliu's ancestors with the "transfer of the Guards in the Hongwu period" 洪武調衛. This repetition aims to emphasise and reinforce the orthodoxy of the Taliu's connection with the state. Scholars have noted the importance of genealogies as sources for studying Chinese social history, particularly the history of families and lineages. However, we must treat genealogies with caution because information can be added to them and their contents amended. ${ }^{105}$ By analysing the legends and genealogies of the Taliu and the texts incised on their tombstones and steles, we can understand how the Taliu constructed their past through their memories of history. Based on available information, I provide my reconstruction of the formation of the Taliu as an ethnic group as follows.

After the weakening of the Guards and Battalions from the mid-Ming onwards, the military households of the Lancang Guard converted themselves step by step into local civilian households. Parallel to this change, the Gao Native Official gradually acquired political authority over the Guards and Battalions. In their struggle with the Zhang for the dominance of the communication route from Beisheng sub-prefecture to Sichuan, the Gao dispatched soldiers to guard Yingpan, which was situated in the mountainous areas southeast of the prefecture. The soldiers included indigenous people (yiren 夷人) and military personnel from the Lancang Guard who had become localised (zaidihua 在地 化). Intermingling with indigenous peoples over a long period resulted in intermarriages and the soldiers gradually becoming the unique ethnic group known as the Taliu. This group formed in response to two major changes in the military: first, the decline of the Guards and Battalions; second, the localisation of military households and their integration with local indigenous people. A tomb inscription of the first ancestor of the Chen family 陳氏始祖 (born in the Jiajing era; died in the Wanli era) and his wife states, "The family originated from this father, continual succession of descendants began from this mother" 追溯淵源此公肇起, 延綿嗣續是母開先. The Chen were a Taliu family. Thus, we may construe that as an ethnic group the Taliu formed sometime between the Jiajing and Wanli periods (1522 to 1620). 
As an important military force of the Gao Native Official, the Taliu not only strengthened control over upland resources, such as land, produce and communication routes but also created a set of cultural habits and religious beliefs different from those of the Han. In particular, local elites created the wedding customs of “Qingchunpeng” 青春棚 and “Guoqiguan”過七關 and of having a Han fortune teller (xiansheng 先生) and a Taliu Duoxi 鐸系 preside at funeral and burial ceremonies. These practices displayed Han and indigenous cultural characteristics and served as significant cultural indicators for maintaining ethnic boundaries while remoulding local ethnic relations and Taliu history and culture.

\section{Conclusion}

The Ming heavily relied on Guards and Battalions to govern ethnic groups in Yunnan. The Lancang Guard played an important role in controlling the communication routes between Yunnan and Sichuan, constraining the power of native officials in northwest Yunnan, helping repress the armed rebels of Iron Chain Gorge, and maintaining stability on the provincial border. In addition, it coordinated relations between the Ming court and the native officials in northwest Yunnan, constrained the military strength of these native officials, and promoted social change in local society. That is, by establishing postal relay stations, forts and outposts, advocating Confucian education, constructing irrigation facilities, establishing markets and introducing other measures, the Lancang Guard gradually embedded the Ming state system into local societies under the jurisdiction of native officials. It was the guard and battalion system that created the conditions for Ming norms of governance to take root in local society, and the process accelerated the pace of the integration of northwest Yunnan with China proper.

During the lengthy and complicated process of continual interaction with local society, the Lancang Guard caused differentiation among social groups along the communication routes of northwest Yunnan. Military households, Han migrants, cultured men (wenren 文人) and merchants moved to Beisheng sub-prefecture from outside the province. Under the military administrative system, the Han from outside were differentiated from the local indigenous people. There were separate categories of household registration, distinct tax and labour service responsibilities, and differences in access to land, irrigation facilities and other resources. Thus, in effect, the establishment of Guards and Battalions created two separate groups in local society: one group subject to military administration and another group under the jurisdiction of regular bureaucrats (the prefectures, subprefecture, county) and native officials. The administrative status of local residents as military households, civilian households or native households (yihu 夷戶) determined differences in tax and labour service obligations and resource access. ${ }^{106}$ At the same time, local social groups themselves made further distinctions between the three households according to differences in culture and ethnicity, which resulted in the formation of diverse local interest groups. The establishment of state-based household status as well as tax and labour service duties influenced the ethnicisation of social groups in northwest Yunnan from the Ming. 
The Taliu ethnic group formed during the Jiajing-Wanli period as a result of the decline of the guard and battalion system and other factors. Legend and the historical memory of the Taliu's ancestors indicate an origin associated with Han soldiers of the Lancang Guard. The need for the Gao Native Official to legitimise his military power at a time of great political and social turmoil during the late Ming/early Qing period formed the backdrop for the emergence of the Taliu. To acquire orthodox status for their indigenous troops, the Gao emphasised their association with the Lancang Guard and the dynastic state. The legitimisation of Gao military power was necessary to the maintenance and the enhancement of Gao control over communication routes. As an ethnic group formed through intermarriage between migrants from the Guard and indigenous people and claiming pedigree from Central China, the Taliu used historical memories as a cultural method of "legitimising" their status within the imperial hierarchy. ${ }^{107}$ In addition, it had been customary since the Ming dynasty for local gentry and lineages to emphasise the orthodoxy of their status. Thus, people residing at the borders also came to create connections with the state. The troops sent to defend the communication route between Yunnan and Sichuan by the Gao Native Official included localised Guard soldiers and fit into this pattern.

Whether by deploying troops to suppress revolts or by facilitating the submission of tribute by native officials and the payment of taxes, the Lancang Guard performed the crucial functions of supervision and integration. Although the guard and battalion system deteriorated during the mid-to-late Ming, it proved indispensable for strengthening Ming governance over border areas. The Lancang Guard's impact on local society persisted even after the assignment of the Guards and Battalions to the jurisdiction of the sub-prefectures (hua wei gui zhou 劃衛歸州). In the case of Beisheng sub-prefecture, with the decline of the Lancang Guard, the "localisation" of migrant soldiers and constant intermarriage with indigenous people spawned a unique ethnic group, the Taliu. This phenomenon exerted lasting influence on local society along the communication routes in northwest Yunnan after the fall of the Ming and facilitated the establishment of a new political and cultural order in local society.

\section{Notes}

1 Fang Guoyu (2003), pp. 145-332.

2 Taizu Shilu, p. 2805.

3 Beisheng originally formed part of the territory occupied by an ethnic group known to Chinese dynasties as the Shi barbarians (Shiman 施蠻). The Nanzhao King, Yimouxun 異牟尋 (reigned 779-808), opened the area during the Zhenyuan period (785 to 804) of the Tang and named it Beifang Dan 北方賧. Yimouxun forcibly moved the White Barbarians (Baiman 白蠻) of the Mi River 瀰河 together with other peoples, such as the Luoluo 羅落 and Mosuo 麼些, to populate the region and then renamed it Chengji Dan 成偈賧 (later Shanju prefecture 善巨郡); see Zhang Tingyu, Mingshi, p. 8106. The Duan family 段氏 of the Dali kingdom changed the name to Chengji Zhen 成紀鎮 in 1048 (Qingli 8) and appointed Gao Dahui 高大惠 to govern; see Liu Zao, Ed., Qianlong Yongbei Fuzhi, juan 3.

4 Zhang Tingyu, Mingshi, p. 1187. 
5 Liu Zao, Ed., Qianlong Yongbei Fuzhi, juan 4.

6 Chen Wen et al., Yunnan Tujing Zhishu, 4:32a, p. 88.

7 Liu Zao, Ed., Qianlong Yongbei Fuzhi, juan 1.

8 Song Lian et al., Yuan Shi, p. 1464.

9 Liu Zao, Ed., Qianlong Yongbei Fuzhi, juan 25.

10 Huang Ming Enlunlu 皇明恩綸錄.

11 Lijiang Diqu Difangzhi Bianzuan Weiyuanhui, Ed., Lijiang Diquzhi, Shangjuan, pp. 761-764.

12 Liu Zao, Ed., Qianlong Yongbei Fuzhi, juan 25.

13 Based on the tomb inscription of the wife of Gao Mu, "Gaofeng Gaoshi Mu Yiren Muzhiming 誥封高氏木宜人墓誌銘” preserved at Lingyuanqing scenic spot 靈源箐 景區 at the foot of Hu Mountain 壼山 on the outskirts of Yongsheng county city.

14 Lijiang Diqu Difangzhi Bianzuan Weiyuanhui, Ed., Lijiang Diquzhi, Shangjuan, pp. $752-753$.

15 Zhang Tingyu, Mingshi, pp. 1874-1875.

16 Guo Hong, "Bieju Tese de Dili Danyuan de Tixian; Ming Qing Weisuo Fangzhi”, pp. $80-84$.

17 The Yunnan Regional Military Commission commanded twenty Guards, three $Y u$ 御 and seventeen Battalions independent from the Guards 直隸千戶所; see Lu Ren (2006), pp. 74-83.

18 Taizu Shilu, p. 2236.

19 Taizu Shilu, pp. 2245-2246.

20 Taizu Shilu, p. 2579.

21 Taizu Shilu, p. 2717.

22 Taizu Shilu, p. 2787.

23 Taizu Shilu, p. 3134.

24 Taizu Shilu, p. 3373.

25 Zhang Tingyu, Mingshi, p. 8019.

26 Zhang Tingyu, Mingshi, p. 8078.

27 Taizu Shilu, p. 3175.

28 Ma Jianxiong, "Mingdai De Zhaozhou Yu Tiesuoqing: Dianxi Yi 'Bazi' Wei Zhongxin De Dili Huanjing Yu Zuqun Jiangou", p. 243.

29 Zhang Tingyu, Mingshi, p. 8092.

30 Lian Ruizhi (2015), p. 38.

31 Gu Zuyu 顧祖禹, Dushi Fangyu Jiyao 讀史方輿紀要顾祖禹, juan 116. Cited from Fang Guoyu, Ed., Yunnan Shiliao Congkan, Vol. 5, p. 762.

32 Erhai Bingbei Dao Tiesuojing Junying Biji 洱海兵備道鐵索箐軍營廳壁記. See $L i$ Zhongxi Quanji, 7:21a-21b, in Yunnan Sheng Wenshi Yanjiuguan (2009), Vol. 21, p. 11262.

33 Binchuan Pingdao Ji 賓川平盜記, in Yang Shiyu and Zhang Shufang (1993), Vol. 10, p. 91.

34 Ma Jianxiong (2017), p. 247.

35 Shoubei Chenjun shanzhi xu 守備陳君善職序 (undated). See Li Zhongxi Quanji, 6:4b in Yunnan Sheng Wenshi Yanjiuguan (2009), Vol. 21, p. 11227.

36 Editor's footnote: For a detailed account of Zou Yinglong's campaign against Iron Chain Gorge, see Christian Daniels's chapter in this volume.

37 Gu Zuyu 顧祖禹, Dushi Fangyu Jiyao 讀史方輿紀要顾祖禹, juan 116. Cited from Fang Guoyu, Ed., Yunnan Shiliao Congkan, Vol. 5, p. 762.

38 Gu Yanwu, Tianxia Junguo Libing Shu, p. 457.

39 The Dali Guard was founded in the third lunar month of 1382 (Hongwu 15); see Taizu Shilu, p. 2249; The Heqing Yu 鶴慶御, subordinate to the Dali Guard, was founded in 1388 (Hongwu 21); see Tong Zhen Ed., 1714 Heqing Fuzhi, 14:1b, p. 478. The Heqing Guard was founded in 1391 (Hongwu 24), and Heqing prefecture 
was converted into Heqing Military-cum-Civilian prefecture in 1397 (Hongwu 30); see Zhang Tingyu, Mingshi, p. 8093.

40 According to Xiaozong Shilu, p. 2737, the court approved the establishment of Binchuan sub-prefecture 賓川州 and the Daluo Guard 大羅衛 on 23 April 1493 (8/4/Hongzhi 6).

41 Taizu Shilu 太祖實錄, p. 2236.

42 Taizu Shilu 太祖實錄, p. 3504.

43 Liu Zao, Ed., Qianlong Yongbei Fuzhi, juan 7.

44 Liu Zao, Ed., Qianlong Yongbei Fuzhi, juan 1.

45 Wang Shixing, Guangzhi Yi, p. 128.

46 Zhang Tingyu, Mingshi, p. 8110.

47 Chen Wen et al., Yunnan Tujing Zhishu, 4:28b, p. 86.

48 Zhang Tingyu, Mingshi, p. 1187.

49 Zhang Tingyu, Mingshi, p. 7982.

50 Zhang Tingyu, Mingshi, p. 8107.

51 Xuanzong Shilu, 1962, p. 0435.

52 Xuanzong Shilu, 1962, p. 0269.

53 Zhang Tingyu, Mingshi, p. 8098.

54 Taizong Shilu, p. 1506.

55 Renzong Shilu, p. 0300.

56 Liu Zao, Ed., Qianlong Yongbei Fuzhi, juan 25.

57 Mushi Huanpu 木氏宦譜, pp. 15-24.

58 Zhang Tingyu, Mingshi, p. 8098.

59 Liu Zao, Ed., Qianlong Yongbei Fuzhi, juan 25.

60 Zhang Tingyu, Mingshi, p. 8107.

61 Lijiang Diqu Difangzhi Bianzuan Weiyuanhui, Ed., Lijiang Diquzhi, Shangjuan, pp. 752-753.

62 Xiaozong Shilu, pp. 2309-2310.

63 Xiaozong Shilu, p. 2737.

64 Wang Shixing, Guangzhi Yi, pp. 125-126.

65 Wang Shixing, Guangzhi Yi, pp. 126-127.

66 Peng Gang and Zhou Jifeng, Zhengde Yunnan Zhi, 12: 3b, p, 500.

67 Chen Wen et al., Yunnan Tujing Zhishu, 4:32a, p. 88.

68 Chen Wen et al., Yunnan Tujing Zhishu, 4:32a, p. 88.

69 Chen Wen et al., Yunnan Tujing Zhishu, 4:28b, p. 86.

70 Liu Wenzheng, Dian Zhi, p. 999.

71 Liu Wenzheng, Dian Zhi, p. 999.

72 Wuzong Shilu 武宗實錄, p. 0835.

73 Wuzong Shilu 武宗實錄, p. 1363.

74 Wuzong Shilu 武宗實錄, p. 1436.

75 Liu Wenzheng, Dian Zhi, p. 432.

76 Liu Zao, Ed., Qianlong Yongbei Fuzhi, juan 22.

77 Wang Shixing, Guangzhi Yi, p. 80.

78 Wang Shixing, Guangzhi Yi, p. 122.

79 Taizu Shilu, p. 3475.

80 Taizong Shilu, p. 1982.

81 Yingzong Shilu, p. 2605.

82 Chao Bideng 昆必登 “Beishengzhou Ruxue Ji 北勝州儒學記”. In Liu Zao, Ed., Qianlong Yongbei Fuzhi, juan 27.

83 Li Yuanyang. Wanli Yunnan Tongzhi, juan 4, 32b.

84 Liu Zao, Ed., Qianlong Yongbei Fuzhi, juan 17.

85 Liu Zao, Ed., Qianlong Yongbei Fuzhi, juan 19; and Liu Wenzheng, p. 330.

86 Chen Wen et al., Yunnan Tujing Zhishu, 4:28b-29a, pp. 86-87. 
87 Chao Bideng 昆必登 “Beishengzhou Ruxue Ji 北勝州儒學記”. Liu Zao, Ed., Qianlong Yongbei Fuzhi, juan 27.

88 Examples of place names that contain administrative terms related to the Guards include Zhongsuo 中所, Yousuo 右所, Songguan 宋官, Jiguan 季官, Liangguan 梁 官, Qingshui postal relay station, Ximachang 西馬場, Qinjia pu 秦家鋪 and Wuli outpost 五里哨.

89 Peng Gang and Zhou Jifeng, Zhengde Yunnan Zhi, 12:3b, p, 500.

90 Liu Wenzheng, Dian Zhi, p. 269.

91 Liu Wenzheng, Dian Zhi, p. 127.

92 Liu Zao, Ed., Qianlong Yongbei Fuzhi, juan 5.

93 Li Yuanyang, Wanli Yunnan Tongzhi, juan 1, 31a.

94 Liu Wenzheng, Dian Zhi, p. 112.

95 Liu Zao, Ed., Qianlong Yongbei Fuzhi, juan 8.

96 Liu Zao, Ed., Qianlong Yongbei Fuzhi, juan 25.

97 Su Shangwu (1991), p. 15.

98 Yingzong Shilu, p. 1926.

99 Taizu Shilu, p. 3689.

100 The Ming state conscripted auxiliary males (yuding 餘丁) from among soldiers and the family members of civil and military officials (sheren 舍人) to augment the Guard system when it weakened during the fifteenth century. Previously, such individuals were not liable for military service.

101 Yingzong Shilu, p. 2905.

102 Peng Gang and Zhou Jifeng, Zhengde Yunnan Zhi, 2:18b, p. 138.

103 Huang Caiwen (2004), pp. 79-82.

104 The Talu Su 他魯蘇 changed their name to Taliu ren. See Huang Caiwen and Zi Zhiyue (2017), pp. 64-70.

105 Zhao Shiyu (2006), pp. 49-64.

106 Ma Jianxiong (2017), p. 243.

107 Liu Zhiwei (2003), pp. 54-64.

\section{Bibliography}

Chen Wen 陳文 et al., Compilers \& Eds. Yunnan Tujing Zhishu 雲南圖志書, printed in the Jingtai 景泰 era 1450-1457. Shanghai: Shanghai Guji Chubanshe, Xuxiu Siku Quanshu Shibu, Dililei, 2002.

Fang Guoyu 方國瑜, Ed. Yunnan Shiliao Congkan 雲南史料叢刊. Kunming: Yunnan Daxue Chubanshe, 1998. Ten volumes.

Fang Guoyu 方國瑜. "Mingdai zai Yunnan de Juntun Zhidu Yu Hanzu Yimin 明代在雲 南的軍屯制度與漢族移民 (The system Military Farming Colonies in Yunnan and Han Migrants in the Ming Period)”. In Fang Guoyu, Fang Guoyu Wenji 方國瑜文集 (The Collected Works of Fang Guoyu). Kunming: Yunnan Jiaoyu Chubanshe, 2003, Vol. 3., pp. 145-332.

Gu Yanwu 顧炎武. Tianxia Junguo Libing Shu 天下郡國利病書 (The Strengths and Weaknesses of the Various Regions of the Empire). Preface dated 1662. Shanghai: Shanghai Guji Chubanshe, Xuxiu Siku Quanshu Shibu, Dililei, 2002.

Guo Hong 郭紅. "Bieju Tese de Dili Danyuan de Tixian: Ming Qing Weisuo Fangzhi 別 具特色的地理單元的體現-明清衛所方志”. Zhongguo Difangzhi 中國地方志 (2003), No. 2, pp. 80-84.

Huang Caiwen 黄彩文. “Yizu Zhixi Taliu Ren De Lishi Yuanliu 彝族支系他留人的歷 史源流”. Yunnan Minzu Daxue Xuebao 雲南民族大學學報 (Zhexue Shehuixue Ban 哲學社會學版) (2004), No. 3, pp. 79-82. 
Huang Caiwen 黄彩文 and Zi Zhiyue 子志月. “Lishi Jiyi, Zuyuan Xushi Yu Wenhua Chonggou; Yongsheng Yizu Taliu Ren De Zuqun Rentong 歷史記憶, 祖源敘事與文 化重構; 永勝彝族他留人的族群認同”. Xinan Minzu Daxue Xuebao 西南民族大學 學報 (Renwen Shehui Kexue Ban 人文社會科學版) (2017), No. 3, pp. 64-70.

Huang Ming Enlunlu 皇明恩綸錄 (Record of the Gifts of Grace from the Ming Emperor), 1646 (Longwu 2). Published in Suzhou. Held by the Yunnan Provincial library. No pagination.

Li Yuanyang 李元陽, Ed., 1573 Wanli Yunnan Tongzhi 萬曆雲南通志. Beijing: Zhongguo Wenlian Chubanshe, 2011.

Lian Ruizhi 連瑞枝. “Tuqiu, Daofei Yu Bianmin: Yi Yunnan Shanxiang Yimin Wei Hexin De Taolun 土酋，盜罒與編民一以雲南山鄉夷民為核心的討論 (Ethnic Leaders, Bandits and Registered Populations: A Discussion Centred on the Upland Non-registered People of Yunnan)". Lishi Renleixue Xuekan 歷史人類學學刊, No. 13, 1 (2015), pp. 19-55.

Lijiang Diqu Difangzhi Bianzuan Weiyuanhui 麗江地區地方志編纂委員會, Ed. Lijiang Diquzhi 麗江地區志. Kunming: Yunnan Minzu Chubanshe, 2000. Shangjuan pp. 761-764.

Liu Wenzheng 劉文徵. Dian Zhi 滇志. Punctuation by Gu Yongji 古永繼. Kunming: Yunnan Jiaoyu Chubanshe, 1991.

Liu Zao 劉慥, Ed. Qianlong Yongbei Fuzhi 乾隆永北府志.

Liu Zhiwei 劉志偉. "Diyu Shehui Yu Wenhua de Jiegou Guocheng; Zhujiang sanjiaozhou yanjiu de lishixue yu renlei duihua 地域社會與文化的結構過程一珠江三角 洲研究的歷史學與人類學對話”. Lishi Yanjiu 歷史研究 (2003), No. 1, pp. 54-64.

Lu Ren 陸䩲. “Mingdai Yunnan Hanzu Yimin Dingjuqu De Fenbu Yu Tuozhan 明代雲 南漢族移民定居區的分佈與拓展”. Zhongguo Lishi Dili Luncong 中國歷史地理論 叢 (2006), No. 3, pp. 74-83.

Ma Jianxiong 馬健雄. “Mingdai De Zhaozhou Yu Tiesuoqing: Dianxi Yi 'Bazi' Wei Zhongxin De Dili Huanjing Yu Zuqun Jiangou 明代的趙州與鐵索箐: 滇西以“壩子” 為中心的地理環境與族群建構 (Zhaozhou and Iron Chain Gorge in the Ming Period: The Geographical Environment of Basins and the Making of Ethnic Groups in Western Yunnan)”. In Zhao Min 趙敏 and Wang Wei 王維, Eds., Dali Minzu Wenhua Yanjiu Luncong 大理民族文化研究論叢 (Collected Research Articles on Dali Ethnic Groups and Culture), No. 6. Beijing: Minzu Chubanshe, 2017, pp. 229-262.

Mushi Huanpu 木氏宦譜. Kunming: Yunnan Meishu Chubanshe, 2001.

Peng Gang 彭綱 and Zhou Jifeng 周季鳳. Zhengde Yunnan Zhi 正德雲南志. Preface 1510 (Zhengde 5). In Tianyige Cang Mingdai Fangzhi Xuankan Xubian 天一閣藏明 代方志選刊續編, 70 \&71. Shanghai: Shanghai Shudian, 1990.

Renzong Shilu 仁宗實錄. Taibei: Guoli Zhongyang Yanjiuyuan Lishi Yuyan Yanjiusuo, 1962.

Song Lian 宋濂 et al. Yuan Shi 元史. Beijing: Zhonghua Shuju, 1976.

Su Shangwu 蘇尚武. “Langcang Wei Gucheng Jianjie 瀾滄衛古城間介”. In Yongsheng Wenshi Ziliao Xuanji 永勝文史資料選輯, No. 3, 1991, pp. 12-15.

Taizong Shilu 太宗實錄. Taibei: Guoli Zhongyang Yanjiuyuan Lishi Yuyan Yanjiusuo, 1962.

Taizu Shilu 太祖實錄. Taibei: Guoli Zhongyang Yanjiuyuan Lishi Yuyan Yanjiusuo, 1962.

Tong Zhen 佟鎮, Ed., 1714 Heqing Fuzhi 鶴慶府志. Included in Beijing Tushuguan Guji Zhenben Congkan 北京圖書館古籍珍本叢刊. Beijing: Shumu Wenxian Chubanshe, 1988.

Wang Shixing 王士性. Guangzhi Yi 廣志繹. Beijing: Zhonghua Shuju, 1981. 


\section{Huang Caiwen}

Wuzong Shilu 武宗實錄. Taibei: Guoli Zhongyang Yanjiuyuan Lishi Yuyan Yanjiusuo, 1962.

Xiaozong Shilu 孝宗實錄. Taibei: Guoli Zhongyang Yanjiuyuan Lishi Yuyan Yanjiusuo, 1962.

Xuanzong Shilu 宣宗實錄. Taibei: Guoli Zhongyang Yanjiuyuan Lishi Yuyan Yanjiusuo, 1962.

Yang Shiyu 楊世鈺 and Zhang Shufang 張樹芳, Eds. Dali Congshu Jinshi Pian 大理叢 書金石篇. Beijing: Zhongguo Shehui Kexue Chubanshe, 1993. 10 volumes.

Yingzong Shilu 英宗實錄. Taibei: Guoli Zhongyang Yanjiuyuan Lishi Yuyan Yanjiusuo, 1962.

Yunnan Sheng Wenshi Yanjiuguan 雲南省文史研究館, Arranged 整理. Yunnan Congshu 雲南叢書. Beijing: Zhonghua Shuju, 2009.

Zhang Tingyu 張廷玉. Mingshi 明史. Beijing: Zhonghua Shuju, 1974.

Zhao Shiyu 趙世瑜. “Zuxian Jiyi Jiayuan Xiangzheng Yu Zuqun Lishi: Shanxi Hongdong Dahuaishu Chuanshuo Jiexie 祖先記憶, 家園象徵與族群歷史一一山西洪洞大 槐樹傳說解析” 《祖先记忆、家园象征与族群历史一一山西洪洞大槐树传说解析, Lishi Yanjiu 歷史研究, 2006 No. 1. pp. 49-64. 


\title{
4 The Mu Native Official's governance of the Tibetan world and his sponsorship of Tibetan Buddhism
}

\author{
Yamada Noriyuki
}

\section{Introduction}

After submission in 1382, the Ming bestowed the Chinese surname Mu 木 on the local leader of Lijiang A Jia A De 阿甲阿得, appointing him Native Official (tuguan 土官) with jurisdiction over the Naxi 納西 ethnic group. ${ }^{1}$ This arrangement transformed the Mu family into vassals (chenxia 臣下) of the Ming and benefitted the local leader by enabling him to continue ruling his own people. The descendants of A Jia A De served the dynasty as Native Officials for fourteen generations. After the Tianshun era (1457 1464), the Mu Native Official conquered the southern part of Kham (Ch: Kang 康) in Eastern Tibet, known as sBo 'bor ba. ${ }^{2}$ Both Ming and $\mathrm{Mu}$ family sources justify this aggression as creating "a protective hedge" (fanping 藩屏), ${ }^{3}$ or buffer, with Tibetan territory. The Ming indirectly governed ethnic groups in Southwest China by appointing their leaders as imperial bureaucrats, known as native officials. Therefore, previous scholars have explicated territorial expansion by the $\mathrm{Mu}$ family within the framework of this system. ${ }^{4}$ The $\mathrm{Mu}$ family proved themselves obedient vassals of the Ming state, always meeting their obligations to provide tribute, tax and military assistance in times of need. Given these displays of loyalty, it is highly likely that the Ming regarded $\mathrm{Mu}$ military aggression in the southern Kham region as aiding the maintenance of peace and stability in a peripheral area. ${ }^{5}$ However, in reality, the Mu family did not stop at simple military action. It also governed the conquered areas, collecting taxes from the populace, and annexed as well as administered the domains of neighbouring native officials, such as Yongning prefecture 永寧府 in Yunnan and the Salt Well Guard Post (Yanjing wei 鹽井衛)in Sichuan. ${ }^{6}$ In addition to the use of military force, the $\mathrm{Mu}$ family forged ties with the reincarnated lamas of the Karmapa sect, assuming the role of patrons (shizhu 施主) of Tibetan Buddhism by sponsoring the printing at Lijiang of the 'Jang bar bKa' 'gyur (Ch: Lijiang Ban Ganzhuer 麗江版甘珠爾), or the Lijiang version of the Tibetan Tripitaka. ${ }^{7}$ As the leader of the Naxi, the Mu family actively interacted with other ethnic groups and at times became embroiled in power struggles with them. The Mu family strove to maintain stability in its own power base at Lijiang while simultaneously aspiring to leverage its position between the Chinese world of the Ming court and the Buddhist world of Tibet to expand its power and influence. ${ }^{8}$ 


\section{Yamada Noriyuki}

This chapter addresses the question of whether the Mu Native Officials were loyal to the Ming court as vassals. By way of answer, I start by analysing evidence concerning the $\mathrm{Mu}$ family's conquest and governance of two locations in the southern Kham region: Muli and Zhongdian. ${ }^{9}$ Next, I examine the Mu's association with the incarnate lamas of the Karmapa sect through an investigation of Buddhist services and rituals performed by the lamas for the $\mathrm{Mu}$ family and of the woodblocks carved for printing the 'Jang bar bKa' 'gyur.

\section{Sources}

The major historical account of the Mu family is the Mu Shi Huanpu 木氏宦譜 (Genealogy of Native Officials of the Mu Family; hereafter MH). Written in Chinese, this source chronicles nearly a thousand years of the family's history in chronological order from the Shangyuan reign period (760-761) of the Tang dynasty until the abolition of its status as Native Officials in 1723, the year in which the Qing commenced to directly administer the Lijiang area. MH includes the family's certificates of appointment as Native Officials (gaochi 誥勅), records its submission of tribute and the military services it rendered and furnishes detailed information concerning military campaigns by the $\mathrm{Mu}$ family from the Ming onwards. No other Ming dynasty source provides as thorough and comprehensive a description of such topics except the Biographies of Six Masters of the Mu Family who Served as [Native] Prefects of Lijiang in the Ming: Xueshan, Duanfeng, Wenyan, Yulong, Songhe, Shengbai 明麗江知府木氏雪山端峰文岩玉龍松鶴生白六公傳 written by Feng Shike 馮時可, Assistant Administration Commissioner of the Right in Yunnan (Buzheng Shisi You Canyi 布政使司右參議), at the close of the Ming dynasty.

The first half of the Tibetan historical chronicle $M u$ li chos byung (A Political and Religious History of Muli 木里政教史; hereafter MC), which documents the deeds of the ruler of Muli from 1580 to 1735 , contains much information on $\mathrm{Mu}$ family military campaigns. The compilation of Tibetan documents known as rGyal thang gi lo rGyus yig tshigs dByad gZhi phyogs bsGrags (A Compilation of Tibetan sources from the Historical Archives of Zhongdian 中甸蔵文歴史擋 案資料匯編; hereafter GTL) provides data on $\mathrm{Mu}$ family governance of the occupied areas, including on tax collection. For information regarding the association of the $\mathrm{Mu}$ family with the incarnate lamas of the Karmapa sect, I mainly rely on three sources: $b K a$ 'brGyud pa (Biographies of Renowned Monks of the Karma Sect; hereafter GB), the Chos byung mKhas pa'i dGa'sTon (hereafter KPGT), and the Dazang Jiao Xu 大蔵教序 written by the Karmapa Red Hat Lama Gar dBang chos kyi dBang phyug. ${ }^{10}$ I also refer to the Sanzang Shengjiao Xu 三藏聖教序, in which Mu Zeng 木増 (incumbent 1598-1624) explicates his stance on Buddhism. The preface that Mu Zeng wrote in Chinese for this work is included in the catalogue of the 'Jang bar bKa' 'gyur.

The consultation of Chinese and Tibetan sources enables close analysis of the standpoints and attitudes of both the Mu Native Officials and the incarnate lamas of the Karmapa sect and reveals hitherto unknown aspects of their relationship with the Ming dynasty. 


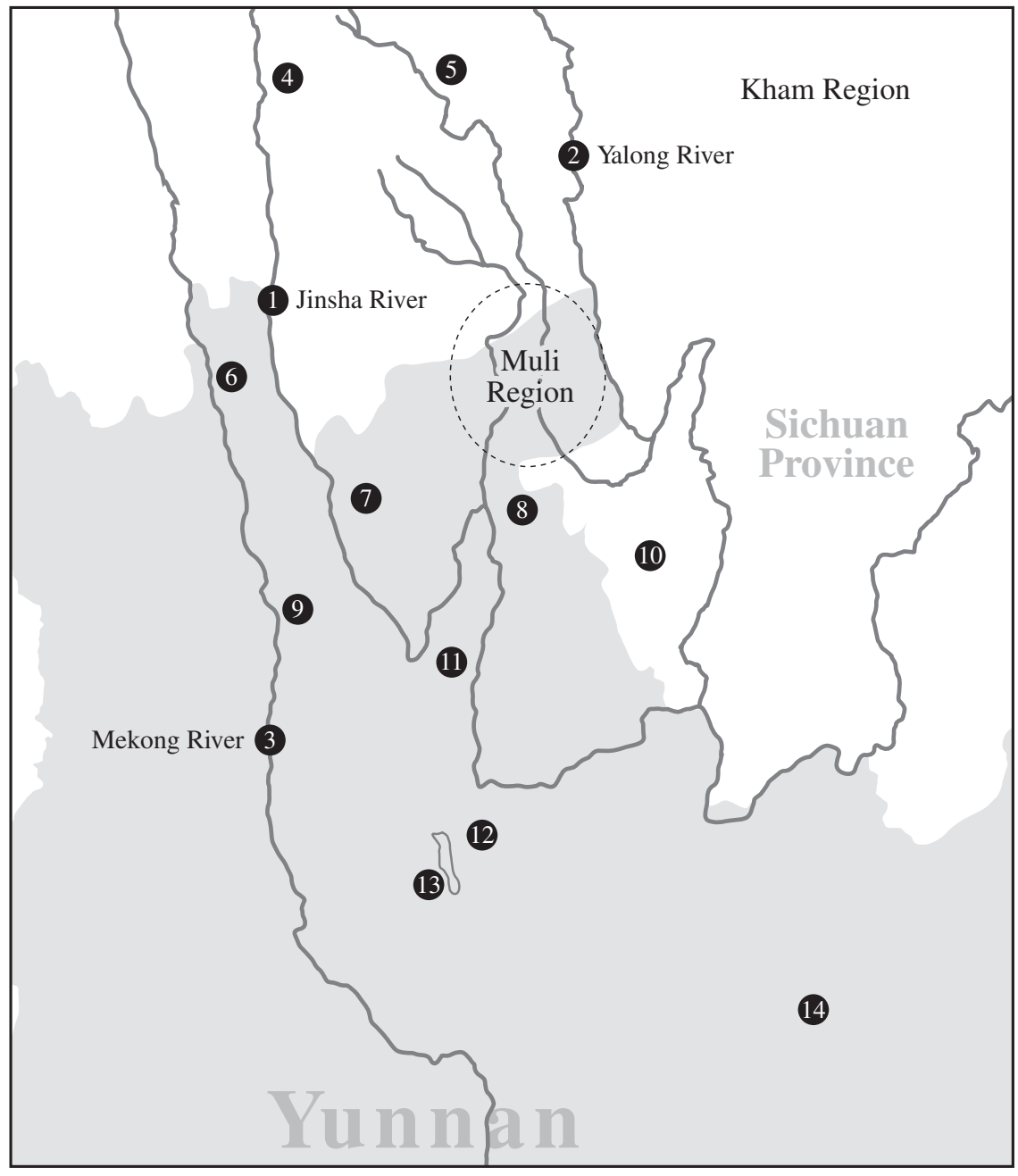

$\begin{array}{lll}\text { (1) Jinsha River } & 6 \text { Deqin (bDe can) } & \text { (1) Lijiang (Sa dam) } \\ \text { (2) Yalong River } & 7 \text { Zhongdian (rGyal thang) } & \text { (12 Mt. Chicken Foot } \\ \text { (3) Mekong River } & 8 \text { Yongning } & \text { (Ri bo bya rKan) } \\ \text { (4) Batan (Ba tang) } & 9 \text { Weixi } & \text { 13 Dali } \\ \text { (5) Litan (Li thang) } & \text { 10 Yanjing } & \text { 14 Kunming }\end{array}$

Map 4.1 Lijiang and the Muli region. 


\section{Yamada Noriyuki}

\section{The Mu Native Official's military campaigns in Southern Kham: the case of Muli}

\section{Physical location of Muli and its leaders}

In his renowned travel diaries, intrepid Ming geographer Xu Hongzu 徐宏祖 (1586-1641) left a detailed account of his visit to Lijiang. He noted a location known to the Naxi as Shuluo 鼠儸" and explained its position as "lying approximately 10 days' journey northeast of the prefecture [Lijiang]". ${ }^{12}$ The $M u$ Shi Huanpu provides a similar description. If this location could be reached in ten days on foot, then Shuluo would have been located at Muli. During the Ming, Yongning prefecture administered Muli (see Map 4.1), which consisted of four Chief's Offices (Zhangguan si 長官司). ${ }^{13}$ The Guangxu era (1875-1911) gazetteer of Yanyuan county records the following: ${ }^{14}$

The Xifan 西番 are the Tufan tribe 土番. The so-called Shanfan 山番 are Bo 嶓 people. They believe in the Buddha, and Ba'er 巴耳 of Muli was their ancestor.

This passage corroborates that the inhabitants of Muli were Tibetan people and that their leader belonged to the lineage of Ba'er. MC provides the following information concerning the lineage of Ba'er.: ${ }^{15}$

The father of the reverend Lama 'Jam dbyang bzang po was born to [parents] from the great tribe called 'Ba' ri, and the wonderful and extremely prestigious Khe ta tribe, and his faith [in Buddhism] was firm. The son [='Jam dbyang bzang po] was born in a mansion known as the Native Official's Yamen 土司衙門 where the reverend's uncle held the golden seal of the Manjusri Bodhisattva Emperor 文殊菩薩皇帝 and believed with a devout heart and faith. This was what people at that time had considered to be so.

The name Lama 'Jam dByang bZang po (1585-1656) is not verified by Chinese sources. However, from the account in $\mathrm{MC}$ we can identity him as the reincarnated Lama Sangs rGyas rGya mTsho. ${ }^{16}$ This source reveals that Lama 'Jam dByang bZang po descended from the lineage of 'Ba' ri, the pronunciation of which resembles the Ba'er recorded in the Yanyuan county gazetteer. Since the sources verify that 'Ba' ri and Ba'er were from Native Official families, we may conclude that they both belonged to the same family line.

\section{Military campaigns}

According to the $M u$ Shi Huanpu, the Mu family repeatedly launched campaigns against Muli between 1462 (Tian Shun 6) and 1616 (Wanli 44). However, the source provides little information on the involvement of Native Officials, such as Mu Dong 木東 (incumbent 1569-1579), Mu Qing 木青 (incumbent 1596-1597), and Mu Yi 木懿 (incumbent 1624-1669), in the campaigns. The Mu Shi Huanpu 
mentions the construction of villages, presumably by Naxi migrants, four times: in 1488 (Cheng Hua 24), ${ }^{17} 1522$ (Jiajing 1), 1536 (Jiajing 15), and 1555 (Jiajing 34). The Mu Shi Liugong Zhuan 木氏六公傳 (Biographies of Six Masters in Mu Family) documents these attacks on the Muli area: ${ }^{18}$

In the Yihai 乙亥 [year] (Wanli 3), the Tubo 吐蕃 of Shuluo 鼠羅 and Dadu 大渡 went rampant. Our lord sent troops that largely defeated the bandits, and set up forts in their lands, thereby extending the territory [of the Mu family].

The incumbent Native Official in 1575 (Wanli 3) was Mu Dong (in office 1569-1579). Although the Mu Shi Huanpu does not explicitly mention that Mu Dong attacked Muli, the entry for 1575 in that source helps clarify the situation: ${ }^{19}$

In this year [Wanli 3; Mu Dong] conquered Laqiuguang 刺秋光, and he ordered his eldest son, A Sheng 阿勝, to lead an army to advance to Naqiyin 那其音, Nibao 你保 and other places. [A Sheng] beheaded over 400 bandits and captured more than three hundred people. It was a great victory.

Mu Dong personally led the punitive expedition against Laqiuguang. His eldest son A Sheng, his successor, who later assumed office as the Native Official known as Mu Wang 木旺, had great success on the battlefield. The cited passage matches the account in the Mu Shi Liugong Zhuan. Although place names, such as Naqiyin and Nibao, must refer to villages in the Muli area, the sources do not mention their construction.

The information provided in these sources enables us to conclude that Ming officials knew that the Mu Native Official had attacked Muli and that he had constructed forts there. However, it is also clear that the accounts in the MuShi Liugong Zhuan and the Mu Shi Huanpu differ. Neither source mentions the scale of the attack by the Mu Native Official and his occupation of Muli.

The Tibetan source MC begins with an account of the Third Dalai Lama's visit to $\mathrm{Li}$ thang 理塘 in 1580 . The source describes the activities of the $\mathrm{Mu}$ Native Official at Muli as follows: ${ }^{20}$

The King of 'jang sa dam rgyal po placed great faith in the Karmapa and the 'Brug pa, so it proved difficult for the Yellow Hats (dGe lugs pa [格魯派]) to spread their teaching and construct temples here. At that time, the two brothers A skya bLa ma dGe 'dun bKra shis [根敦扎西] and Chos sKyong rGya mTsho [曲迥嘉措] drove away enemies opposing the revered doctrines of the Yellow Hats by ingenious methods.

This passage indicates that Tibetans referred to the Mu Native Official as “'jang sa dam rgyal po", meaning the Naxi King of Lijiang. ${ }^{21}$ Hereafter, when citing Tibetan sources, I use the term Naxi King of Lijiang or just Naxi King. As a follower of the Karmapa and the 'Brug pa, the Naxi King exercised substantial influence over the Muli area. Evidence of a faction resisting him clearly 
indicates that his army had invaded Muli. In addition, this resistance surpassed the bounds of mere military conflict, developing into a struggle between two temporal powers supporting different Buddhist sects in Muli. The Naxi King of Lijiang championed the cause of the Karmapa sect, while the anti-Lijiang faction defended the Yellow Hats.

Before examining the links between the Naxi King of Lijiang and the Karmapa sect, let us review the activities of the Yellow Hats at Muli. When the Third Dalai Lama visited Li thang in 1580, the anti-Lijiang faction dispatched a representative to Li thang to invite him to preach at Muli in an effort to introduce the Yellow Hat sect into their area. Although the Dalai Lama did not visit Muli himself, he dispatched Lama Sanggyes Gyatso (Ch: 桑結嘉錯) to preach there. ${ }^{22}$ Two temples constructed after his arrival became centres for the Yellow Hat sect at Muli: Lha sTen Buddhist Temple (Lha sTen dGa' IDan Dar rGyas gLing) and Khe 'ong Buddhist Temple (Khe 'ong bDe ba can bSod nams dar rGyas gLing), completed in 1584 and 1604, respectively. ${ }^{23}$ Tradition held that Lama Sangs rGyas rGya mTsho was reborn into the lineage of the powerful Ba'ri family of Muli, and people recognised the monk 'Jam dByang bZang po as his incarnation. This tradition led the anti-Lijiang faction to wage war against the Naxi King.

We can trace the deployment of troops by the Naxi King of Lijiang through accounts in $\mathrm{MC}::^{24}$

Then, when the abbot mNga ris Gari 阿里葛綘教主 went to the Yalong River 雅龍江 (Tib: Nya chu) for a trivial reason, he built a Buddhist temple at Lud Ge 魯吉 in which he resided. On account of this, the Kar 'Jang [followers of the Naxi King] acting from unworthy motives destroyed [this temple] in a dishonest manner. Thereupon, the Lama moved to the opposite side of the Yalong River, where he constructed rkang rab can Temple 崗讓 堅寺 and took up residence there.

Abbot mNga ris Gari served as abbot of Khe 'ong Buddhist Temple at the time, and he was known as dPal 'Byor rGya mTsho. ${ }^{25}$ Kar 'Jang (Ch: 葛降) was an abbreviation of the term KardGon Jang rDzong, which literally means "temples of the Karmapa sect and villages of the Jang" (Naxi followers of the Naxi King of Lijiang). The expression refers to the territory under the influence of the Karmapa sect and the Naxi or to the Naxi followers of the Karmapa sect. In this chapter, I use the Tibetan word Kar 'Jang when referring to this group associated with the Naxi King of Lijiang. rKang rab can Temple lay on the east bank of the Yalong River at a location known as Ma rDe rong, ${ }^{26}$ which is transliterated into Chinese as Maidilong 麥地龍. ${ }^{27}$ On the basis of this evidence, we can conclude that after the Kar 'Jang ousted dPal 'Byor rGya mTsho, the abbot of Khe 'ong Temple, from Lu dGe Temple, fled to rKang rab can Temple, located on the east bank of the Yalong River. Although the location of Lu dGe Temple remains unclear, judging from the fact that $\mathrm{dPal}$ 'Byor rGya mTsho crossed the Yalong River, we can conclude it must have been located on the western side of the river.

Another passage in $\mathrm{MC}$ records as follows: ${ }^{28}$ 
Using Lha sTen Temple (Ch: Lading Temple 拉頂寺) and Khe 'ong Temple (Ch: Kangwu Temple 康塢寺) as bases, the Kar 'Jang acted in wicked ways and with mean thoughts, as if in conspiracy with dogs and wolves. This resulted in people in the area no longer adhering to the teaching of the Yellow Hat sect in their temples. Due to this change, ['Jam dByang bZang] went to the salt wells (Tshwa thog) in China, where he united hearts with Chinese officials and four or five other officials through the expediency of wisdom, and built bkra shis chos gling Temple at 'Jo lo (Jueluo 覺羅). He amicably laid the foundations of the Yellow Hat sect. This came about due to the Kar 'Jang destroying the new temple built by dPal 'Byor rGya mTsho, the $\mathrm{mNga}$ ris Gari abbot [of Khe 'ong Buddhist Temple at the time].

This passage reveals that the Kar 'Jang invasion forced 'Jam dByang bZang po to take refuge at the salt wells. Since it records the residential presence of Chinese officials, we can assume that these salt wells were located at the Yanjing Guard 鹽井衛. The exact position of 'Jo lo remains unclear. However, from the context, it must have been a village within the jurisdiction of the Yanjing Guard, thus outside the reach of the Kar 'Jang.

The movement of the two monks reveals the extent of the Naxi King's control in this part of the Tibetan world. That dPal 'Byor rGya mTsho sought shelter on the east bank of the Yalong River indicates that the Naxi King's sphere of influence reached the west bank of the Yalong River at the time. The escape of 'Jam dByang bZang po from Muli to the Yanjing Guard indicates that he already controlled the whole of southwest Muli. Because the construction of Khe 'ong Temple occurred in 1604 and dPal 'Byor rGya mTsho succeeded the first abbot, gNas brTan tsgul khrims bZang, ${ }^{29}$ we may conclude that dPal 'Byor rGya mTsho resided here after 1604. Attacks by roaming Chinese bandits in 1647 delivered a blow to the Naxi King's domination of Muli, and thereafter, his control of the area gradually weakened. ${ }^{30}$ Availing themselves of this opportunity, the people of Muli rose up to eliminate the influence of the Naxi King. 'Jam dByang bZang po returned to Muli and assumed the position of abbot in Lha sTen (Lading) and Khe 'ong (Kangwu) Temples in $1648 .{ }^{31}$ We can surmise that the Naxi King's supremacy over Muli ended in 1648.

How did the Naxi King govern Muli? The Mu Shi Liugong Zhuan records that he established villages. Similar records appeared in MC. Their contents are summarised below:

1 Of the original 'Jang (Naxi) villages and Karmapa temples, only four to five remained after the attacks by the roaming Chinese bandits. ${ }^{32}$

2 Yas pa (Ch: Yipa 依帕), A 'phred rGya bya (Ch: A Ting Ga Qia Gong 阿亭 噶恰共) and others waged war against the Karma Kargyu Buddhist temples and the 'Jang villages. ${ }^{33}$

Point 1 reflects the devastation wrought on the 'Jang or Naxi villages by the roaming Chinese bandits in 1647. The targeting of 'Jang villages by the bandits 
corroborates the existence of the villages at that time. The passage that supports point 2 follows point 1 . Therefore, we can assume that all these events occurred in 1647. Although we possess no information regarding the two individuals Yas pa (Ch: Yipa 依帕) and A 'phred rGya bya (Ch: A Ting Ga Qia Gong 阿亭噶恰 共), point 2 indicates that Muli leaders staged attacks on 'Jang villages. That is, points 1 and 2 document the expulsion of the Naxi King's military forces and corroborate the existence of 'Jang villages. Considering that Tibetans constituted the original inhabitants of Muli, we can assume that the Mu Native Official constructed these villages after his occupation.

The Naxi King suppressed the Yellow Hat sect and promoted the activities of the Karmapa when he controlled Muli. MC clearly articulates this point: ${ }^{34}$

[The Kar 'Jang] informed [the people] saying, "if you do not continue to send children to become monks at the two temples of Lha sTen and Khe 'ong, the parents will end up carrying the [severed] heads and hands of their children on their backs." After the Kar 'Jang issued these orders to the various Mi sDe, it was no longer uncommon at all for them to send [their children] to serve as monks at the two temples.

The term Mi De (Ch: Mide 彌德) referred to serfs on the manors of secular rulers. After the construction of Lha sTen and Khe 'ong Temples, each serf family in the Muli area sent one child to these two temples to become monks. However, it seems that the serfs had stopped sending their children to serve as monks at these temples when the Muli area came under the domination of the Naxi King. To resolve the situation, the Naxi King made the serfs send their children to the temples as they had in the past by threatening them, sabotaging the activities of the Yellow Hat sect, and indicating his intention to promote the Karmapa sect. Direct interference in religion reveals that the Mu Native Official was a military conqueror of Muli as well as a protector of the Karmapa sect and a denouncer of the Yellow Hat sect.

\section{Administration under the Mu Native Official}

This section investigates the administration of the $\mathrm{Mu}$ Native Official of the newly acquired territory in Muli by an examination of how he collected tax from the local populace.

Data concerning tax collection at Tibetan villages appear in a Tibetan language source titled sPom rag bKra shis rab brTan dzong mNga' 'og gi sGrig lam yig cha (Documents on Regulations concerning sPom rag bKra shis rab brTan dzong; hereafter PKG). ${ }^{35}$ The village known as sPom rag lay in today's Benzilan Township 奔子欄鄉 in Deqin county 德欽縣, Yunnan province. The latest date mentioned was 1756 (Qianlong 21). Therefore, this source was most likely written during the Qianlong period. Despite the lack of precise dates, it records the tax quotas for the periods of domination of Zhongdian 中甸 by three different regimes: the Naxi King of Lijiang (the Mu Native Official), the GUSi 
qan and the Qing dynasty. ${ }^{36}$ The record of taxation in sTong shod pa, a village during the time of the King of Lijiang states as follows: ${ }^{37}$

Taxes for sTong shod village during the Naxi King of Lijiang's period amounted to 46 srang (Ch: sang 桑). [These taxes] were collected from one $r T a$, eleven $d u d$ chen, and seven me dMar households administered by the 'bas sras [village head]. ${ }^{38}$

The terms $r T a$, dud chen (large households), and me dMar (single households) were units for taxation purposes, ${ }^{39}$ and srang was a unit of currency. I have assembled the tax quotas for all the villages in Table 4.1.

This evidence indicates that the $\mathrm{Mu}$ Native Official controlled even the smallest villages and collected tax from them. Although MC does not furnish information as detailed as that found in the $\mathrm{PKG}$, it provides a glimpse of tax collection in Muli. It records the Lama 'Jam dbyang bzang po as proclaiming to the local people as follows: ${ }^{40}$

It would be better for you to pay tax to me than to the Naxi King ('jang po). I could conduct both the political and the religious affairs of your villages, and pray that you find peace in this life, annihilate suffering in future and past lives and that you are able to comprehend the tranquillity of emancipation.

The Lama 'Jam dbyang bzang po spoke these words directly after political power shifted into his hands following the expulsion of the Naxi King from Muli. He notified the local inhabitants that he had replaced the Naxi King as the ruler, and he ordered them to pay taxes to him from then on, not to the Naxi King. In effect, this proclamation testifies that the Naxi King had exacted taxes from the Muli populace in the past.

Data in the fragmentary historical sources indicate that the $\mathrm{Mu}$ Native Official maintained a system for collecting tax from the populace in the southern Kham area. The PGK account of the Mu Native Official exacting taxes from

Table 4.1 Villages and their tax quotas

\begin{tabular}{ll}
\hline Village Name & Amount of Tax Due \\
\hline Stong shod pa & 46 srang \\
Shel phu md & 27.5 srang \\
Nyin khung pa & 23 srang \\
Skye rtsa zo regs & 55 srang \\
Gnam zhing & 23 srang \\
Za kha & 23 srang \\
Chu lung mdzod & 23 srang \\
\hline
\end{tabular}

Source: Compiled from the PKG. 
even the smallest of villages reveals the depth of his control over local society, testifying that it reached to the lowest stratum. The systematic collection of tax had great significance because it indicates that the Ming state did not impose restrictions on the Mu Native Official's administration of the southern Kham. Ming non-interference contradicts the idea that the military occupation of Muli was for the establishment of a "protective hedge" (fanping 藩屏) to defend Ming borders from Tibetan incursions. Tax collection was part of the Mu Native Officials' own agenda.

\section{The Mu Native Official and Tibetan Buddhism}

In contrast to Chinese sources, including the Mu Shi Huanpu, which do not mention the association of $\mathrm{Mu}$ Native Officials with Tibetan Buddhism, Tibetan sources provide a wealth of information. In this section, I first trace the interaction between $\mathrm{Mu}$ Native Officials and the reincarnated lamas of the Karmapa sect through the GB and the KPGT, and then analyse what the Mu family aimed to achieve by constructing Buddhist buildings at Lijiang. Next, I examine the interaction between the Mu Native Official and the lamas of the Karmapa sect as revealed by their carving of the woodblocks for the 'Jang bar bka' 'gyur (The Jang edition of the Tibetan bka' 'gyur (Ch: 麗江版甘珠爾)) at Lijiang. The purpose is to clarify the connection between the two.

\section{Interaction between the Mu Native Official and the Karmapa sect}

The GB and the KPGT cover associations between the Mu Native Official and the Karmapa sect over a long period of approximately 220 years from 1408 to 1631. The number of accounts differs according to time period. Only four accounts survive for the years from 1408 to 1559 , and the number suddenly increases after 1560. The accounts provide data on four generations of Native Officials: Mu Gao 木高 (incumbent 1527-1553), Mu Dong 木東(incumbent 1569-1579), Mu Wang 木旺 (incumbent 1580-1596), and Mu Zeng 木增 (incumbent 1598-1624). Accounts of the reincarnated lamas appear in the biographies of the Ninth-generation Black Hat Lama dBang phyug rDorje, the Fifthgeneration Red Hat Lama dKon mChog yan lag, the Fifth-generation Situ Chos kyi rGyal mTshan, ${ }^{41}$ the Sixth-generation Red Hat Lama Gar dBang chos kyi dBang phyug, the Third-generation $\mathrm{dP}^{\prime} \mathrm{bo}^{42}$ gTsug lag rGya mTsho, and the Seventh-generation Red Hat Lama Ye shes sNying po and Drung yig bLo gros nor Idan.

\section{Printing of the Jang edition of the Tibetan bka' 'gyur}

Interaction between the Mu Native Official and the reincarnated lamas of the Karmapa sect encompassed a broad range of activities, including votive offerings, exchanges of handwritten messages and letters, the carving of woodblocks for printing the Jang edition of the Tibetan bka' 'gyur and the construction of 
Buddhist temples. Most accounts concerned votive offerings, as, for example, the following source: ${ }^{43}$

[DKon mChog yan lag] conducted Buddhist services in the twelfth month and performed ceremonies [for celebrating] the beginning of the iron $/ \mathrm{male} /$ monkey year [1560]. Gifts from the sponsor's field of blessing delivered by vassal ministers of the King of Lijiang arrived.

Sources record seven similar cases in which the $\mathrm{Mu}$ Native Official submitted offerings to the Karmapa sect at the new year.

In this section, I trace the events leading to the carving of the woodblocks of the Jang edition of the Tibetan bka' 'gyur, possibly at Zhongdian, and its printing at Lijiang. In 1581, dBang phyug rDorje visited Lijiang and agreed to allow $\mathrm{Mu}$ Wang 木旺, the incumbent Native Official of Lijiang, to print the Jang edition of the Tibetan bka' 'gyur. ${ }^{44}$ However, preparations only commenced in 1608 under the administration of Mu Zeng 木增. ${ }^{45}$ In 1609, Mu Zeng personally wrote a letter requesting that Gar dBang chos kyi dBang phyug lend him the woodblocks of the Tshal pa bar's Bstang'gyur ${ }^{46}$ to carve his own woodblocks for printing copies at Lijiang, ${ }^{47}$ and he received the woodblocks the same year. ${ }^{48}$ The printing of the Jang edition of the Tibetan bka' 'gyur was completed in $1621 .{ }^{49}$ To celebrate this auspicious event, Gar dBang chos kyi dBang phyug presided over a rab tu gNas (Ch: Shanzhu Fahui 善住法会) ritual service to consecrate the work at Khang sar mGo Temple at Zhongdian, ${ }^{50}$ with Mu Zeng in attendance. The GB describes the event: ${ }^{51}$

They [brought] the Jang edition of the Tibetan bka' 'gyur to the entrance of the Khang sar mGo [temple]. The Naxi King also went there full of strength as if to compete with Lord Indra 帝釋天. On the second day, [they] proceeded with preparations for the rab tu gNas ritual to consecrate the Jang edition of the Tibetan bka' 'gyur. The official ceremony was performed with favourable auspice on the third day, with the appearance of propitious omens such as myriad white light rays.

This passage does not mention the year in which the lama performed the consecration ritual. The GB chronicles an earlier performance of a different $r a b t u$ gNas ritual in 1619. Therefore, we may assume that the lamas performed these ceremonies every few years. Another entry in this text, which appears well after the one translated above, records the printing of the Jang edition of the Tibetan bka' 'gyur but mentions no date. ${ }^{52}$

This undated entry matches the description of the completion of the Jang edition dated 1621 in the Sanjiao Shengjiao Xu 三教聖教序. Based on this evidence, the rab tu gNas ritual noted in the preceding translated passage must have occurred between 1619 and 1621 .

The Preface to the Tripitaka in DS describes the rab tu gNas ritual executed for the consecration of the Jang edition of the Tibetan bka' 'gyur as follows: ${ }^{53}$ 
Not long afterwards, urged on by the great king [Mu Zeng], we [the sixthgeneration Red Hat Lama Gar dBang chos kyi dBang phyug] and the great incarnate Lama Chos kyi rGyal mTshan [the Fifth generation of Situ 司徒] arrived at $\mathrm{sBa}$ shes where the grand palace of the Naxi King of Lijiang stood. [The great King] invited us to perform the rab tu gNas ritual [for the carving of the woodblocks for the Jang edition of the Tibetan bka' 'gyur]. I followed the auspicious Śrīcakrasamvara mandala (Ch: Jixiang Shengle Mantuoluo 吉祥勝樂曼佗羅) ceremony, and Situ Chen Po followed the Vajravarāhī mandala ceremony (Ch: Jin'gang Haimu Mantuoluo 金剛亥母 曼佗羅), and after completing the preparations, main tasks and rearrangements with more than one hundred monks, [we] spoke auspiciously with wisdom thus making it a solemn event.

The present-day palace is shown in Figure 4.1.

The text fails to mention the precise year of this event. However, because the Dazangjing $X u$ was written in 1614, it must have occurred before this date. The venue was not Zhongdian but Lijiang. Gar dBang chos kyi dBang phyug conducted the ceremony. We also learn that in addition to the reincarnated Lama of the Karmapa sect, Chos kyi rGyal mTshan, the fifth generation of Situ, also performed a ceremony at Lijiang. Neither the GB nor the Dazangjing $X u$

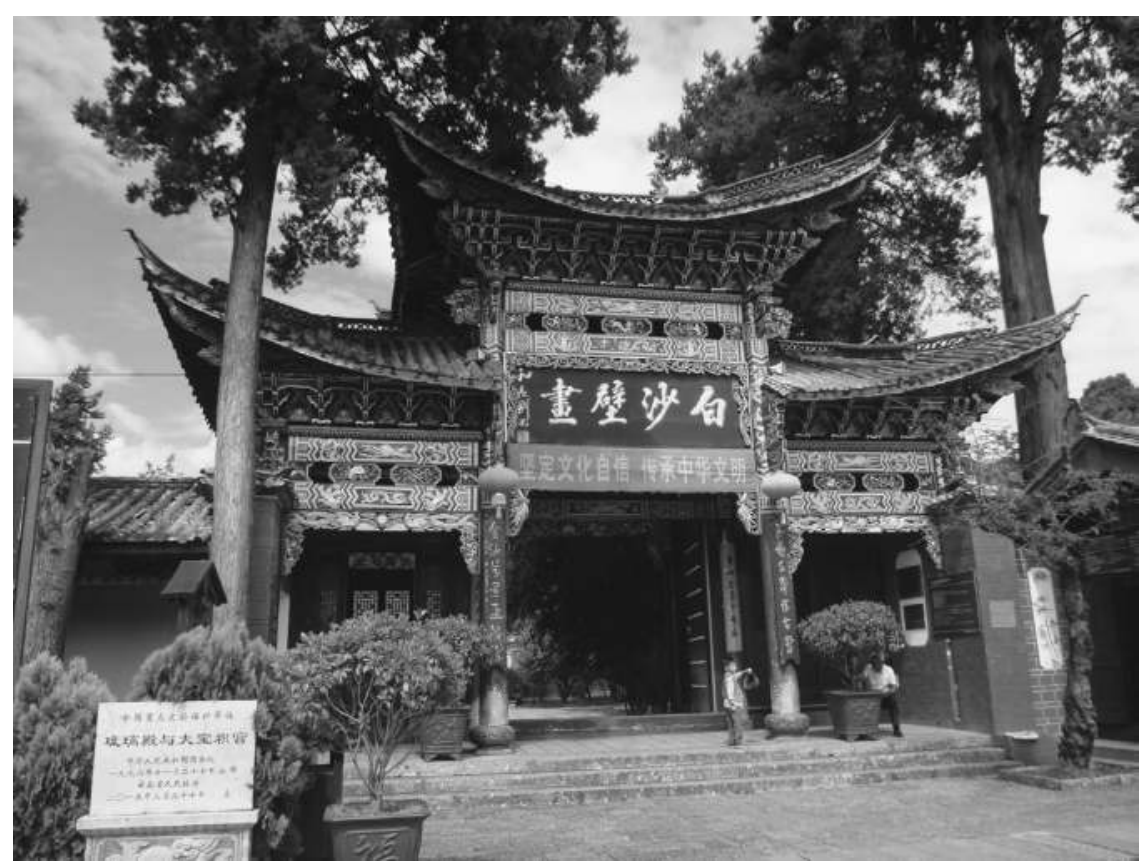

Figure 4.1 The present-day sBa shes palace at Baisha 白沙, Lijiang.

Photograph: Yamada Noriyuki, 23 August, 2018. 
provides the date for the completion of preparations for the printing of the Jang edition of the Tibetan bka' 'gyur. However, from the preceding passage and the Dazangjing $X u$, we can surmise that they ended before 1614 .

We know that the GB and the Dazangjing $X u$ record different venues for the rab tu gNas ritual for consecration without providing firm dates for the conclusion of the printing. The ceremonies may have been held twice, and errors could possibly have crept into the texts. However, both sources agree that Gar dBang chos kyi dBang phyug presided over the rab tu gNas ritual with Mu Zeng in attendance, which reveals an intimate relationship between the two men.

As previously mentioned, the Naxi King presented printed copies of the Jang edition of the Tibetan bka' 'gyur to Gar dBang chos kyi dBang phyug. This edition was the third woodblock printing of the Tibetan bka' 'gyur Bstang'gyur, following the editions printed during the Yongle and Wanli periods. ${ }^{54}$

\section{Construction of Buddhist temples}

This section examines the construction of four Buddhist temples: two at Zhongdian (rGyal thang) and two at Muli. According to the GB and the KPGT, the two temples at Zhongdian (rGyal thang) were Khang sar $\mathrm{mGo}^{55}$ and Tsi shang. ${ }^{56}$ The Lha sTen and the Khe 'ong Temples at Muli both originally served as centres for the Yellow Hats in the region. However, the Mu Native Official later forced the temples to convert to the Karmapa sect.

We possess five documented cases of incarnate lamas of the Karmapa sect visiting Lijiang, not counting relations with the preceptor of the Mu Native Official. These instances illuminate the association of the Mu Native Official with the incarnate lamas. The most detailed account chronicles the visit of Mi bsKod rDo rJe to Lijiang in 1516, when he met Mu Ding, the Native Official incumbent 1503-1526. One part of it reads as follows: ${ }^{57}$

First of all, the King [Mu Ding] led the people to the camping ground to welcome [Mi bsKod rDo rJe]. The next day, [Mu Ding] invited them to a palace. [Mu Ding] promised [Mi bsKod rDo rJe] not to wage any wars against Tibet for thirteen years, to send five hundred children each year [to serve as monks], to build one hundred Buddhist temples. [Mi bsKod rDo rJe] stayed [in Lijiang] for 7 days. Prior to his visit, the Naxi King of Lijiang did not revere Buddhism. Afterwards, he believed without discrimination in the common doctrines of Buddhism and those of Karmapa sect.

Mi bsKod rDo rJe managed to persuade the incumbent Native Official Mu Ding to consent to cease hostilities against the Tibetans. Mu Ding did not keep the promise for long as he renewed his aggression in the southern Kham area. However, the mediation of military affairs by a reincarnated lama was remarkable. The agreement to send children to serve as monks and the pledge to construct 100 temples can be construed as indicating the conversion of the $\mathrm{Mu}$ family to Buddhism. 
In addition, the following passage in GB reveals that a member of the $\mathrm{Mu}$ Native Official family had entered the monkhood: ${ }^{58}$

Karma rin chen, an Iha btsun 拉尊 [member of the royal family who had become a monk] of Lijiang, was the youngest son of the Dharma King (Ch: Fawang 法王) bSod nams rab brTen. Since there were no laymen, he took the tonsure, and relinquishing the administration of state affairs strove to put into practice the important teachings at a place of tranquillity. He attained the wisdom of finding the rightful path.

This passage records Karma rin chen as a child (Iha btsun) of Mu Zeng, referred to here as the Dharma King bSod nams rab brTen. The genealogy in the Mu Shi Huan pu does not record any of Mu Zeng's sons becoming monks. No other sources clarify whether this contradiction simply represents a case of the MuShi Huan pu not recording Mu Zeng's son joining the monkhood or that the son's entering the monkhood has no foundation in fact. Despite the lack of corroborative data, the recording of the son's name in GB indicates the strong possibility that Karma rin chen was a member of the $\mathrm{Mu}$ family, even if not a biological son of Mu Zeng.

Next, we consider another piece of evidence recorded in GB: ${ }^{59}$

The donors (shizhu 施主) and the recipient (futian 福田) went to Lijiang. After this, a few disciples went to Ri bo bya rKang (Ch: Jizu Shan 雞足山, or Mt. Chicken Foot) to worship from gSang khong.

This passage describes events following the previously mentioned $r a b$ tu gNas ritual for the consecration of the Jang edition of the Tibetan bka' 'gyur. The term "donor" refers to $\mathrm{Mu}$ Zeng and his officials, while "recipient" denotes the reincarnated lama of the Karmapa sect and the monks accompanying him. ${ }^{60}$ They travelled to Lijiang together, and some of the entourage journeyed on to Chicken Foot Mountain, a sacred site for Chinese Buddhists located in Binchuan county 賓川縣 in western Yunnan. According to the 1692 version of the Gazetteer of Chicken Foot Mountain 雞足山志, Mu Zeng constructed pavilions for storing Buddhist sutras (Cangjing ge 藏經閣) at Xitan 悉檀寺 and Huayan 華嚴 寺 Temples. ${ }^{61}$ Although not Tibetan Buddhist temples, Mu Zeng probably led Karmapa sect monks to hold Buddhist services at these temples that he had constructed at Mt. Chicken Foot.

Needless to say, "donor" refers to individuals who donate money or goods to Buddhist temples and monks. The Mu Native Official made donations to the reincarnated lama of the Karmapa sect, constructed temples, and sponsored the carving of the woodblocks for printing the Jang edition of the Tibetan bka' 'gyur.

Such donations required abundant funds. Therefore, to provide this scale of patronage, the Mu Native Official had to possess a fiscal base. Part of these funds most likely derived from the taxes collected in the Tibetan areas under his administration. The Mu Native Officials used tax revenue collected in the southern part 
of the Kham area to finance various Buddhist services and to sponsor the Karmapa sect. It seems that the lamas of the Karmapa sect unselfishly used these donations for the welfare of the local people in the southern Kham region. That is, under this arrangement, the lamas of the Karmapa sect altruistically returned the charitable donations received from the $\mathrm{Mu}$ Native Officials to the local people, thus converting part of the religious offerings into secular welfare support.

The incarnate lamas of the Karmapa sect counselled the Mu Native Official to terminate military action, albeit without success. They initiated the Mu Native Official and his family into the doctrines of Buddhism by converting them to the faith and performed the rab tu gNas consecration ritual for the carving of the woodblocks for the Jang edition of the Tibetan bka' 'gyur. In addition, as previously noted, one member of the $\mathrm{Mu}$ family entered the monkhood. The relationship between the Mu Native Official and the Karmapa sect lamas was undeniably that of donor and recipient.

\section{Construction of Buddhist structures at Lijiang}

A small number of buildings that reveal the relationship between the Mu Native Official and the Karmapa sect lamas still stand at Baisha 白沙 and Shuhe 束河 in Lijiang, certain of them preserving Buddhist murals. ${ }^{62} \mathrm{Mu}$ Native Officials provided the funds for the construction of these buildings. In this section, I investigate the purpose for which the Mu Native Official constructed these edifices.

GB records the visits of the Karmapa sect lamas to Lijiang. Consider the following three passages:

1 The Reverend Mi bsKod rDo rJe sat in his sedan chair, and [the Naxi King] invited him to his seat, and then invited his disciples into the palace. The Naxi King went to the door in the middle and presented the $\operatorname{ka~dar~}^{63} \ldots$ Tea was served, then the Naxi King presented one hundred rolls of valuable silk that he had prepared earlier as gifts, offered all kinds of food, and he served meals in the palaces. Displaying gold and silver, he requested the sprinkling of the wheat seeds of blessing. Three queens offered ornaments and adornments, and the ceremony for giving rise to the Bodhicitta (Ch: putixin 菩提心) was performed. ${ }^{64}$

2 The next day, amid the religious musical instruments, prayer flags and prayer banners, the Naxi King came riding on his $d o l a^{65}$ to receive them, and the donors and the recipients attended the welcome banquet. On the following day, the Naxi King announced that he would entertain at the sBa she palace the entire camp together with those who had come to welcome him. For the Naxi King, [Gar dBang chos kyi dBang phyug] performed the consecration ceremonies (abhiseka) of hundred longevity and of the Vajiramālā (Ch: jin'gang man 金剛蔓) from the coloured sand mandala. The Naxi King not only converted to the Dharma, he also maintained intimate ties with monks well versed in Chinese 
[Buddhism], and always showed respect for the Mahayana. He taught people who had studied the Avatamsaka Sūtra (Flower Ornament Sutra Ch: Huayan Jing 華嚴經) to perfect the great mudra (Ch: dayin 大印) and the six precepts (Ch: liufa 六法). One day, the Naxi King invited the reverend [Gar dBang chos kyi dBang phyug] and Situ rin po che to the gallery in the palace where he presented them with many expensive silk clothes that he had placed there beforehand. [Gar dBang chos kyi dBang phyug] then put on his hat, and [the Naxi King] quickly issued orders for the block-carving and printing of the Tibetan bka' 'gyur. ${ }^{66}$

3 The Naxi King of Lijiang and his officials extended an invitation as donors of the Buddhist teaching, so [Chos dByings rDo rje] changed the direction [of his travels] towards them. [Chos dByings rDo rje] then went to the sBa she palace. Because [he found the country of the Naxi King] as prosperous as the good augury of Vaisravana (the god of wealth), [Chos dByings rDo rje] performed a mass and wore a deep blue coloured hat in honour of [the Naxi King] who became full of hope from the many sermons that he received at the abhiseka [consecration ceremony] by the Avalokiteśvara Bodhisattva (Ch: Guanshiyin Pusa 觀世音菩薩). ${ }^{67}$

Passage (1) describes events that occurred when Mi bsKod rDo rJe, the Black Hat Karmapa incarnate Lama, visited Lijiang in the early sixteenth century. Passage (2) records the visit of Gar dBang chos kyi dBang phyug, the Red Hat Karmapa incarnate Lama, to Lijiang during the early seventeenth century. At that time, the lama conducted the consecration ceremony (abhiseka) for the Naxi King of Lijiang. In addition, he imparted tantric techniques to people (this term probably refers to Mu Zeng and others) who had studied the Avatamsaka Sutra or Flower Garland Sutra. Passage (3) chronicles the visit of Chos dByings rDo rje, the Black Hat Karmapa incarnate Lama, to Lijiang during the mid-seventeenth century and his performance of the consecration ceremony (abhiseka).

In all three instances, the cited Buddhist activities occurred in the palace at Lijiang. Where was this palace located? The Mu Native Official governed from his yamen, known as the Mu residence ( $\mathrm{Mu} \mathrm{Fu}$ 木府), in today's Dayan Township 大研鎮 (the present-day $\mathrm{Mu}$ residence is shown in Figure 4.2). To the Tibetans, this edifice may have appeared as magnificent as a palace. However, to judge from the buildings that remain standing today, Dajue palace 大覺宮 at Shuhe village 束河村 and Dabaoji palace 大寶積宮 at Baisha village 白沙村 would have been appropriate venues to which to invite reincarnated lamas to perform Buddhist services. The reason is that although these venues were not as splendid as the $\mathrm{Mu}$ residence, the main deities of the mural paintings that decorated their buildings derived from Tibetan Buddhism.

The Mu residence, Dajue palace and Dabaoji palace could all have been possible locations for the reception of the reincarnated lamas. The question is which of these buildings had the highest probability of being regarded as a palace by the Tibetans?

In answer, the first point is that only passage (1) mentions the name of the palace. It records the $\mathrm{sBa}$ she palace, which is close to the Chinese Baisha 白沙. ${ }^{68}$ 
The passage in the Dazangjing Xu cited earlier records that the rab tu gNas ritual conducted to consecrate the woodblock printing of the Tibetan bka' 'gyur was performed at "sBa shes where the grand palace of the Naxi King of Lijiang stood". In addition, passages (2) and (3) state that the lama performed the consecration ceremony (abhiseka) for the King, that is for Mu Zeng, the Native Official of Lijiang, at the sBa she palace and performed tantric ceremonies there. In any case, we can be certain that the reincarnated lamas recognised the building standing at Baisha today as the palace of the Naxi King and performed Buddhist services there. The Mu Native Official may have constructed this building and created Buddhist murals for the purpose of inviting reincarnated lamas to conduct Buddhist services. The $\mathrm{sBa}$ she palace at Baisha most likely functioned as a venue for deepening the association between the Mu Native Official and the lamas of the Karmapa sect within the framework of the donor-recipient relationship.

\section{Mu Native Official, the Karmapa sect and the Lijiang edition of the Tibetan bka' 'gyur}

Secular rulers commonly patronised particular Buddhist sects. Thus, the $\mathrm{Mu}$ Native Official's sponsorship of the Karmapa sect was not unusual. Association between donors and recipients reflected the intentions of secular rulers in sponsoring Buddhism. In this section, to understand why the Mu family chose to patronise the Karmapa sect, we consider the attitude of Mu Zeng towards Buddhism and how Lama Gar dBang chos kyi dBang phyug appraised Mu Zeng.

In the Sanzang Shengjiao Xu 三藏聖教序, Mu Zeng explained his motive for printing the Tibetan bka' 'gyur at Lijiang: ${ }^{69}$

The carving of the woodblocks [and the printing of the text], will spread [Buddhism], thus universally educating all sentient beings, who by developing themselves will awaken to the other shore [i.e., nirvana], and together achieving the wisdom of a Buddha (zhengjue 正覺) will ascend the diamond throne (Skt: vajrasāna, Ch: jin'gang zuo 金剛座), ${ }^{70}$ and similarly attain the perfect fruit (yuanmanguo 圓滿果) of nirvana.

By disseminating the Tibetan bka' 'gyur, Mu Zeng aimed to spread the teachings among all sentient beings and convert them to Buddhism. This intention indicates that $\mathrm{Mu}$ Zeng understood the religious significance of printing the Tibetan bka' 'gyur, thus revealing that he was not a mere financial sponsor.

Next, we consider the attitude of the Tibetans towards Mu Zeng, the patron, as recorded in the Preface to the Tripitaka (DS) written by Gar dBang chos kyi dBang phyug. First, let us consider how he understood the printing of the Tibetan bka' 'gyur at Lijiang: ${ }^{71}$

The State-Protecting Dharma King (Sa sKyong chos kyi rGyal po chen po Ch: Huguo Da Fawang 護國大法王) of Lijiang instructed the state preceptor (guoshi 國師) and his ministers to issue orders to each of his numerous 
subjects scattered all over [his kingdom, directing them] not to think of hardship because this [printing of the Tibetan bka' 'gyur] is for the greatest and highest of purposes, and would spread the benefit of speedy attainment.

The Tibetan Lama clearly understood that Mu Zeng ordered the cutting of the woodblocks and the printing of the Tibetan bka' 'gyur at Lijiang to propagate Buddhist teachings. Now that we have established this fact, let us consider how Gar dBang chos kyi dBang phyug appraised Mu Zeng as a secular ruler: ${ }^{72}$

The Naxi kingdom ('jang po) is a propitious place situated between China and Tibet. When a youth, the prince of this royal family that rules for the sake of goodness uttered the auspicious name of Karma mi pham tse dBang bSod nams rab brTan, expressed admiration and performed good [deeds]. Relying on compassion he has protected the kingdom and made the throne splendid.

Here, Gar dBang chos kyi dBang phyug praises Mu Zeng as a King ruling with an awakened or enlightened mind (putixin 菩提心). That is, the Lama recognised him as a monarch who ruled according to Buddhist law.

In his Preface to the Tripitaka, Gar dBang chos kyi dBang phyug expressed his wish that people be granted access to the woodblocks so that they could print the Tibetan bka' 'gyur for their own use: ${ }^{.73}$

Therefore, the King, his ministers, the monks, the laity, the sextons at the temples, the messengers and all those who will probably come to venerate this edition must acquaint themselves with this [i.e., the Tibetan bka' 'gyur Bstang'gyur]. Original copies of the dharma are rare, so if [the woodblocks of] the canon are hidden and stored for safekeeping in a quiet place out of fear that frequent usage [printing] will damage them, it will be impossible to continue making offerings to them. This is the most precious of treasures, and we can only venerate this treasure by increasing [copies of it through printing] and by people not leaving the texts wrapped [in cloth] and never opened.

The Lama insisted that the woodblocks be openly accessible to facilitate frequent printing of the Tibetan bka' 'gyur. He expected people to make Buddhism flourish in Lijiang through the dissemination of the printed text.

The cited passages reveal how Mu Zeng and the reincarnated Lama of the Karmapa sect Gar dBang chos kyi dBang phyug viewed the carving of the woodblocks for the Lijiang edition of the Tibetan bka' 'gyur and their hopes for its future dissemination. They clearly portray Mu Zeng as a follower of Buddhism, not merely as a financial sponsor. For this reason, the Lama referred to $\mathrm{Mu}$ Zeng as State-Protecting Dharma King (Sa sKyong chos kyi rGyal po chen po), recognising him as a monarch ruling his people according to Buddhist law. Both men shared a common ground of similar values founded on Buddhism. 


\section{Significance of the association}

Finally, let us consider the significance of the association between the $\mathrm{Mu}$ Native Official and the reincarnated lama of the Karmapa sect in the political and military context of the southern Kham area.

Lamas exerted immense influence on the populace in areas that believed in Tibetan Buddhism. ${ }^{74}$ The Karmapa lamas wielded strong power in southern Kham because their sect was originally based there. Their power has already been noted in the example of Mi bsKod rDo rJe visiting Lijiang in 1516 in an attempt to use his influence as a Lama to stop hostilities. Although similar examples cannot be found for later periods, we can surmise that lamas may have counselled the Mu Native Official to cease fighting or, alternatively, that the $\mathrm{Mu}$ Native Official may have relied on lamas to mediate disputes.

Unlike others, such as the Sa kya sect, the Karmapa sect did not possess abundant wealth and property. Therefore, to maintain and expand their religious order, it was essential for them to find donors. Given the economic situation, for

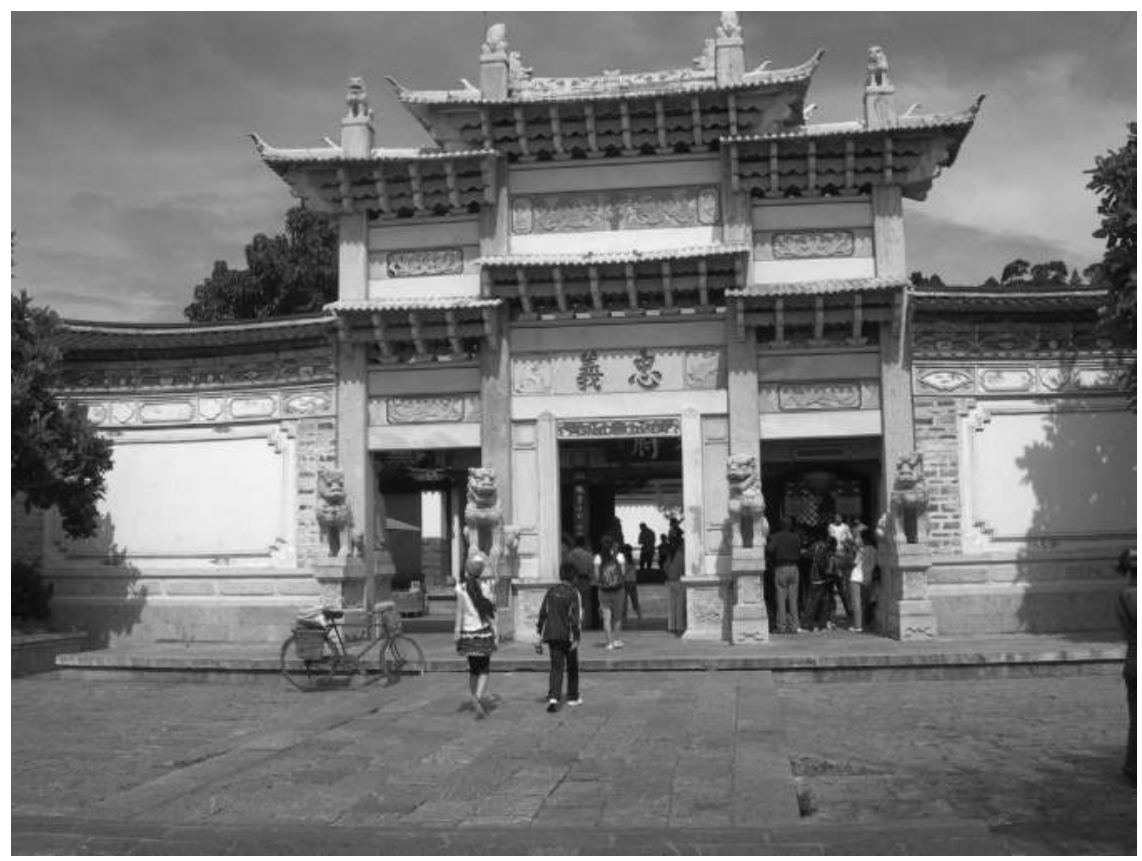

Figure 4.2 The reconstructed stone gate standing at the entrance to the $\mathrm{Mu}$ Native Official yamen in Lijiang.

The words "loyalty and righteousness (zhongyi 忠義)" can be seen on the gate. The same words were carved on old stone gate photographed by Joseph Rock during the Republican period. The Ming court understood the Mu Native Official's occupation of parts of the Tibetan world as an act of loyalty because this action helped prevent incursions from Tibet.

Photograph: Yamada Noriyuki, 30 July 2009. 
its own stability, the Karmapa sect required the support of the $\mathrm{Mu}$ Native Official, who controlled vast parts of southern Kham. In the end, the Karmapa succeeded in winning over the Mu Native Official, who as a donor and follower of Buddhism sponsored the carving of the woodblocks for the Lijiang version of the Tibetan Tripitaka. This printing constitutes an event of great significance because it marks the third edition of the $b k a$ ' 'gyur. Conditions in the southern Kham area from the mid-fifteenth to mid-seventeenth century created a milieu for the emergence of common interests between the Mu Native Official and the Karmapa sect. In fact, it is most likely that the Mu Native Official succeeded in dominating the southern Kham area because of these common interests. Viewed from this perspective, the $\mathrm{Mu}$ Native Official might appear to have merely utilised religion to gain political control over the area. However, the role of the $\mathrm{Mu}$ Native Official as a donor enabled the reincarnated lamas of the Karmapa sect to co-operate with him, further facilitating the sharing of similar values founded on Buddhism by both parties. That is, the circumstances compelled the Mu Native Officials to utilise Buddhism and at the same time made it possible for them to embrace values similar to those of the Tibetans they dominated.

\section{Conclusion}

As previously noted, Chinese sources describe the motive for the Mu Native Official's conquest and promotion of Naxi migration into the southern Kham area and the levying of taxes there as creating a "protective hedge" (fanping) for defence against Tibetan incursions. In this way, the Ming tacitly approved aggrandisement by the $\mathrm{Mu}$. Tibetan sources, however, do not corroborate this view and in fact reveal a completely different stance. Nowhere do Tibetan sources record the $\mathrm{Mu}$ as a link between the Tibetan world and the Chinese world (chüka sekai 中華世界) due to their appointment as native officials by the Ming Emperor. There is no mention of the Mu advancing into the Tibetan world as representatives of the Ming court. The Political and Religious History of Muli refers to the $\mathrm{Mu}$ Native Official as the 'Jang rGyal po, or Naxi King of Lijiang, and addresses his followers as Kar 'Jang. Clearly, the Tibetans were not concerned with the status of the $\mathrm{Mu}$ as Native Officials within the Ming political system. For them, which Tibetan Buddhist sect the $\mathrm{Mu}$ patronised constituted a far more important issue: the Yellow Hats (Gelugpa) or the Karmapa? In this chapter, I have noted the interaction of the Mu with the reincarnated lamas of the Karmapa sect, the Mu's sponsorship of the carving of the woodblocks for the Lijiang edition of the Tibetan bka' 'gyur, and that Mu family members joined the monkhood. These activities demonstrate that the $\mathrm{Mu}$ Native Officials shared similar Buddhist values with the Tibetans and that these values transcended sectarian differences. However, Mu sponsorship of the Karmapa sect by no means signified that the Tibetans regarded their military campaigns in Tibetan areas as being undertaken for the purpose of defending the Karmapa sect.

The Ming court sponsored the printing of the Yongle and Wanli editions of the Tibetan bka' 'gyur. The Zhengde Emperor immersed himself in Tibetan 
Buddhism, even adopting a Buddhist name. Viewed from this perspective, the $\mathrm{Mu}$ Native Official's patronage of Tibetan Buddhism could be interpreted as an expedient political strategy, i.e., a tactic aimed at using religion to control populations in conquered areas. However, in evaluating this interpretation, we should consider the major differences in the attitudes of the Ming court and the Mu Native Official towards Sino-Tibetan relations. Whereas the Ming court was unable to rule Tibet, the Mu Native Official conquered and actually governed a part of Tibet, the southern Kham area. As members of a non-local ethnic group, it would have been impossible for the Mu Native Official and his followers to sustain dominance over a Tibetan area for a protracted period of time without sharing and practising Tibetan Buddhist values. In addition, according to documentary evidence, interaction between the Mu Native Official and the Karmapa sect began in the early fifteenth century in a period before the Mu began launching attacks on the southern Kham area. This fact clearly indicates that the Mu Native Official did not forge links with the Tibetan Buddhist sect only to expedite governance. Whether $\mathrm{Mu}$ family members actually believed in Tibetan Buddhism remains unverifiable. However, the historical facts reveal that the Mu Native Official did interact continually with the Karmapa sect over a long period, which indicates that the lamas of that sect treated them as true followers of Tibetan Buddhism.

Thus, the political power struggles between the Karmapa and Yellow Hats (Gelugpa) arose from conflict between the two sects and were not due to ethnic confrontation between Naxis and Tibetans. It is only by examining associations with Tibetan Buddhism that we can bring to light historical facts that are not evident if one restricts oneself to studying relations between the Mu Native Official and the Ming state.

By examining the actual governance of the southern Kham area and the Mu family's interaction with the Karmapa sect, this chapter has demonstrated that the Mu Native Official exercised autonomous political authority and possessed the ability to maintain order within $\mathrm{Mu}$ jurisdictions in Lijiang and other areas during the Ming. In addition, the presented evidence reveals the one-sidedness inherent in the Sino-centric idea that the "virtue" (de 德) of the Chinese emperor extended to the jurisdictions of native officials. The case of the Mu conquering and governing Tibetan populations reveals a hitherto unstudied aspect of the Ming native official system.

\section{Notes}

1 Mushi Huanpu, p. 14.

2 sBo 'bor ba refers to the area stretching from the eastern bank of the Jinsha River to the western bank of the Yalong River. According to today's administrative divisions, the area belonged to the northwest part of Yunnan and the southwest part of Sichuan.

3 For instance, the stele “Dagong Da sheng Kejie Ji 大功大勝克捷記” of 1561, carved after a victory against Tibet, reads, "For generations, the Mu family has served as a 'protective hedge' (fanli 藩蘺) for the Ming”; see Fang Guoyu (1984), p. 1202. Yunnan Mu Dafu Shengbai Xiansheng Zhongxiao Xiaoaoji 雲南木大夫生白先生忠 孝記, by Cai Yizhong 蔡毅中, describes Mu family military action as resulting in "the extension of territory by several hundred li and the building of more walled and 
palisaded fortifications (chengzha 城柵) as protective hedges (fanli 藩蘺)"; see Fang Guoyu (1998), Vol. 5, p. 561.

4 See Feng Zhi (1990), pp. 25-48; Wang Hengjie (1995); Yu Haipo and Yu Jiahua (2002); Yang Fuquan (2004), pp. 55-60; and Zhao Xinyu (2004). Additionally, Rock (1947), p. 110, does not examine the relationship between Mu Native Officials and Tibet in great depth, and Ahmad (1970, pp. 123-124), when discussing the military occupation of the south Kham area, merely cites Rock's study.

5 Yamada Noriyuki (2007), pp. 1-13.

6 Yu Haipo and Yu Jiahua (2002, pp. 97-104) view the military action conducted by the Mu Family Native Official against Yongning prefecture 永寧府 and the Salt Well Guard Post (Yanjing wei 鹽井衛) as military assistance to relatives by marriage and do not examine how the Ming handled this aggression.

7 The $b K a$ ' 'gyur is a compilation of the sutras and vinaya from the Tripitaka. The Abhidharama is known as the bsTan 'gyur.

8 I use the term "the Chinese world" (chūka sekai 中華世界) to refer to the sphere over which the Emperor ruled by his virtue (de 德) and governed according to the Confucian principles of propriety ( $l i$ 禮). The term “the Tibetan world" indicates the area occupied by peoples who spoke Tibetan languages as their mother tongues and shared values based on Buddhism; see Ishihama Yumiko (2001). It does not include Mongolia, although Mongolia constituted part of the Tibetan Buddhist world.

9 Muli 木里 lies in today's Sichuan. Zhongdian 中甸 (now known as Xianggelila county 香格里拉縣) is located in northwest Yunnan. Tibetan sources refer to Zhongdian as rGyal thang.

10 Dazang Jiao Xu 大蔵教序 is included in the catalogue dkar chag 目録 of the 'Jang bar bKa' 'gyur. The term "catalogue" is a general appellation for the lists of names of sutras and books with prefaces, epilogues and postscripts attached to or recorded in the bKa' 'gyur and bsTan 'gyur.

11 Shuluo 鼠儸 is a Chinese phonetic transcription of the Naxi term "Shulo"; see Rock (1947), p. 110.

12 Xu Hongzu, Xu Xiake Youji, p. 877.

13 Chen Wen 陳文 et al., Jingdai Yunnan Tujingzhishu, 4:26a, p. 85.

14 Pei Yuan 培源, Compiler, Guangxu Yanyuan Xianzhi, Wubeizhi 武備志, Tusi 土司 entry.

$15 \mathrm{MC}$, p. 18.

16 MC, p. 18. Sangs rGyas rGya mTsho is regarded as the reincarnation of bLo gros chos sKyong, the fifth abbot of the dGa' IDan Temple; see MC, p. 13.

17 The original has Chenghua 24. However, in fact, the year was Hongzhi 1 (1488).

18 Feng Shike 馮時可, Mushi Liugong zhuan, in Fang Guoyu (1998), Vol. 5, p. 559.

19 Mushi Huanpu, p. 41.

20 MC, p. 14.

21 In Tibetan, 'Jang means Naxi, and Sa dam or Sa tham refers to Lijiang 麗江.

22 MC, pp. 12-13.

23 There is no record of Sangs rGyas rGya mTsho preaching at Muli in the DL3. The VDS or Religious History of the Yellow Hat Sect states:

rGyams Lha khang sTe dGa' IDan dar rGya gling Temple (Lha sTen Temple) was built at the same time as Li thang Temple by Sangs rGyas rGya mTsho and spread the teachings of the great Tsong kha pa in Muli superbly.

(VDS, p. 299)

MC, p. 15, records the founder of Khe 'ong Temple as Tshul khrims bZang po, which matches the account in the VDS, p. 299, noted above. Additionally, the VDS documents the names of the abbots of Lha sTen Temple after Sangs rGyas rGya mTsho, including that of 'Jam dByang bZang po.

24 MC, p. 16. 
25 VDS, p. 299.

26 MC, p. 16.

27 According to MC, p. 16, at this time, rKang rab can Temple was a branch temple of Khe 'ong Temple. In addition, according to the Muli Zangzu Zizhixianzhi Bianzuan Weiyuanhui (1995), p. 897, there is a temple named Gangraojing'erchi 崗繞井二赤 within Maidilong xiang 麥地龍郷 today. To judge from the similarity of pronunciation, it is probably the same as rKang rab can Temple.

28 MC, p. 21.

29 MC, p. 15.

30 The roaming Chinese bandits who delivered a blow to the Lijiang King's domination of Muli probably belonged to one of the rebel groups active during the turbulence of the late Ming/early Qing transition. The Mushi Huanpu, pp. 52-53, records that articles and documents bestowed by the Emperor were reduced to ashes in the attacks by the roaming bandits in the same year of 1647. Although this source does not enable us to conclude that the bandits who attacked Muli also came to Lijiang, considering the $\mathrm{Mu}$ Native Official's submission to the Qing and his elimination under the gaitu guiliu 改土 歸流 policy, domination by the Naxi King most probably started to weaken from 1647.

31 MC, p. 27; VDS, p. 299.

32 MC, p. 25.

33 MC, p. 25.

34 MC, p. 22.

35 PKG is included in the GTL or compilation of Tibetan documents known as rGyal thang gi lo rGyus yig tshigs dByad gZhi phyogs bsGrags (A Compilation of Tibetan sources from the Historical Archives of Zhongdian 中甸蔵文歴史擋案資料匯編).

36 According to Tezuka Toshiaki (1999), p. 61, the Naxi King of Lijiang lost his dominion over Zhongdian c.1670 as a result of the invasion by GUSi qan Gusi. Later, the forces of qosiGud from Qinghai 青海 were expelled, and the Qing court introduced the native official system in 1725 (Yongzheng 3); see Zhao Xinyu (2004), p. 309.

37 GTL, p. 75.

38 The term 'bas sras is thought to be a transliteration of the Naxi term be se, which means village head (Ch: cunzhang 村長); see Yunnan Sheng Bianjizu, Zhongguo Shaoshu Minzu Shehui Lishi Diaocha Ziliao Congkan Xiuding Bianji Weiyuanhui (2009), Vol. 3. p. 9.

39 According to the Chinese translation of the Tibetan text of GTL, me dMar refers to one household ( $h u$ 戸), one dud chen or large household (dahu 大戸) consisted of twenty-five me $d M a r$, or households, and two dud chen were termed $r T a$; see GTL, p. 228. According to Giuseppe Tucci, in central Tibet, one household was known as hor, twenty-five households constituted one dud chen, or large household, and two dud chen comprised one $r T a m G o$; see Tucci (1949), Vol. 1., p. 14. Although the names differed, the units were the same in Zhongdian and Central Tibet.

40 MC, p. 28.

41 The Yongle Emperor bestowed the title of Dasitu 大司徒 on the disciple of the Fifthgeneration Black Hat Karmapa Lama De bZhin gSheg pa known as Chos kyi rGyal mTshan. The lineage of Situ started with him; see Douglas and White (1976), p. 155.

42 This name derives from the first-generation Chos dbang lhun dru, whom people called dPa' bo; see Douglas and White (1976), p. 170.

43 GB, Vol. 2, pp. 88-89.

44 GB, Vol. 2, p. 180.

45 SZ, p. 4b.

46 According to Imaeda Yoshirō (1989), p. 329, Tshal pa dGe ba'i bLo gros established the Tshal pa bar bKa' 'gyur version of the Tripitaka at Tshal gung thang Temple by copying and amending the old sNar thang version of the Tripitaka. Various manuscript and printed versions of the $\mathrm{bKa}$ ' 'gyur derive from this version.

47 GB, Vol. 2, p. 266. 


\section{Yamada Noriyuki}

48 GB. Vol. 2, p. 267.

49 Sanzang Shengjiao Xu, pp. 11-13.

50 Tradition places the location of Khang sar Temple 康司寺, which was destroyed in 1673, at today's Xiao Zhongdian Tuanjie village 小中甸團結村; see Yunnan Sheng Zhongdian Difangzhi Bianzuan Weiyuanhui (1997), p. 233.

51 GB, Vol. 2, p. 275.

52 GB, Vol. 2, p. 286.

53 DS, p. 31a.

54 The Yongle 永樂 edition was printed at Beijing in 1410 (Yongle 8), and the Wanli 萬 曆 edition of 1605 (Wanli 33) was a reprint of the Yongle edition with slight amendments; see Imaeda Yoshirō (1989), p. 330.

55 KPGT, p. 723.

56 GB, Vol. 2, p. 275. According to Yunnan Sheng Zhongdian Difangzhi Bianzuan Weiyuanhui (1997), p. 233, this temple was located at Da Zhongdian Jiefang village 大中甸解 放村 but was destroyed in 1673. A passage in the GB, Vol. 2, p. 319, states, “The Naxi King of Lijiang constructed a new temple. Because a letter inviting a Lama was received, Drung pa shag rog pa requested that he himself be dispatched". This text verifies that the Naxi King constructed a temple, but it fails to mention the name of the temple.

57 GB, Vol. 2, p. 18.

58 GB, Vol. 2, p. 348.

59 GB, Vol. 2, p. 275.

60 Xu Hongzu, Xu Xiake Youji, p. 1137, records that the incarnate Lama of the Karmapa sect visited Chicken Foot Mountain, but his visit was later than the trip documented in the GB.

61 Fan Chengxun, Compiler, Jizu Shan Zhi, juan 4, 5b-6a.

62 As I explain later, the murals at Lijiang depict Daoist as well as Buddhist deities. However, the principal deities are Tathagatas 如來 and Boddhisattvas 菩薩 from the Tibetan Buddhist pantheon, and many of the images drawn around them are derived from Buddhism. For this reason, I refer to these murals as Buddhist murals.

63 Cloth that represents a good augury.

64 GB, Vol. 2, pp. 17-18.

65 According to Tshul khrim, Emeritus Professor at Otani University, a do la was a chariot-like vehicle on which people could sit.

66 GB, Vol. 2, p. 274.

67 GB, Vol. 2, p. 331.

68 According to Rock (1947), p. 73, Baisha 白沙 is a transliteration of the Naxi word Boa shi.

69 Sanzang Shengjiao Xu, 6b-7a.

70 The vajräsana throne was the Buddha's seat on attaining enlightenment.

71 DS, 31a.

72 DS, $27 b$.

73 DS, 34a.

74 Satō Hisashi (1986), p. 154.

\section{Bibliography}

\section{Abbreviations for Tibetan sources}

DL3: Ngag dbang bLo bZang rGya mTsho, Dalai lama V, rje btsun thams cad mKhyan pa bSod names rGya mTsho'i rnam thar dNgos grub rGya mThso'i shing rTam. 1646 Ed. In The collected works of Vth Dalai Lama. Vol. nya. Gangtok, 1991-1995.

DS: Gar dBang chos kyi dBang phyug, bDe bar gShegs ba'i bKa' gangs can gyi brDas 'dren pa ji sned ba'i phyi mo par gyi tshogs su 'khod pa'i byung ba gSal bar brDzod 
pa legs byas kyi dad pa'i gZugs kun nas sNang ba nor bur in po che'i me long zhes bya pa bZhugs so. In Imaeda Yoshirō 今枝由郎, Ed., Catalogue du Kanjur tibétain de l'édition de 'Jang Sa tham. Tokyo: International Institute for Buddhist Studies, 1982.

GB: Si tu pan chen chos khi 'byung gNas, 'Be lo tshe dBan kun khyab. bKa 'brGyud pa, sGrub brGyud karma kam tshang brGyud pa rin po che'i rnam par thar pa rab 'byams nor bu zla ba chu sel gyi phreng (Biographies of Renowned Monks of the Karma Sect). New Delhi: D. Gyaltsan and Kesang Legshay, 1972, Vol. 2.

GTL: rGyal thang gi lo rGyus yig tshigs dByad gzhi phyogs bsGrags (A Compilation of Tibetan sources from the Historical Archives of Zhongdian). Published under the Chinese title 中甸藏文歷史擋案資料匯編. Yunnan Minzu chubanshe 雲南民族出版社, 2003.

KPGT: gTsug lag 'phreng ba. Chos byung mKhas pa'i $d G a$ ' sTon gyi yan lag gSum pa bod kyi sKabs las brGyad pa sGrub rGyud karma ka ma tshang gi chos byung rRyas pa bZhugs. In mkhas pa'i dga' ston of dpa' bo gtsug lag. Ed. Lokesh Chandra (Indo-Asian Literature). New Delhi: International Academy of Indian Culture. 1959, Vol. 9 (pa).

MC: Ngag dBang mKhyen rab, mu li chos 'byung 木里政教史 (A Political and Religious History of Muli). Sichuan mingzu chubanshe 四川民族出版社, 1992.

PKG: sPom rag bKra shis rab brTan dzong $m$ Nga' 'og gi sGrig lam yig cha (Documents on Regulations concerning sPom rag bKra shis rab brTan dzong). This text is included in GTL, the compilation of Tibetan documents known as rGyal thang gi lo rGyus yig tshigs dByad gZhi phyogs bsGrags (A Compilation of Tibetan sources from the Historical Archives of Zhongdian) published under the Chinese title 中甸藏文歷史擋案資料 匯編 (Yunnan Minzu chubanshe 雲南民族出版社, 2003).

VDS: sDe srid Sangs rGyas rGya mTsho, Dga' lDan chos 'byung vaidūrya ser po (The Religious History of the Yellow Hat Sect). Beijing: Zhongguo Zangxue Chubanshe 中 國藏學出版社, 1989.

Ahmad, Zahiruddin. Sino-Tibetan Relations in the Seventeenth Century. Rome: Istitute Italiano Il Medio Ed Estremo Oriente, 1970.

Chen Wen 陳文 et al., Compilers. Jingdai Yunnan Tujingzhishu 景泰雲南圖經志書. In Xuxiu Siku Quanshu 續修四庫全書, 682. Shanghai: Shanghai Guji Chubanshe 上海古 籍出版社, 1995.

Douglas, Nick and Meryl White. Karmapa: The Black Hat Lama of Tibet. London: Luzac, 1976.

Fan Chengxun 范承勲, Compiler. Jizu Shan Zhi 雞足山志. In Siku Quanshu Cunmu Congshu 四庫全書存目叢書 Shibu 史部, Vol. 238. Tainan: Zhuangyan Wenhua Shiye Youxian Gongsi 莊嚴文化事業有限公司, 1996.

Fang Guoyu 方國瑜. Yunnan Shiliao Mulu Gaishuo 雲南史料目錄概說. Beijing: Zhonghua Shuju, 1984.

Fang Guoyu 方國瑜, Ed., Yunnan Shiliao Congkan 雲南史料叢刊. Kunming: Yunnan Daxue Chubanshe 雲南大学出版社, 1998. Ten volumes.

Feng Shike 馮時可. Mushi Liugongzhuan 木氏六公傳 (Ming Lijiang Zhifu Mushi Xueshan Duanfeng Wenyan Yulong Songhe Shengbai Liugongzhuan 明麗江知府木氏 雪山端峰文岩玉龍松鶴生白六公傳). In Fang Guoyu 方国瑜 (1998), Vol. 5.

Feng Zhi 馮智. “Ming Zhi Qingchu DianZang zhengjiao Guanxi Guankui” 明至清初滇藏 政教關係管窥. Zhongdian xianzhi tongxun 中甸縣志通訊, Vol. 3 (1990), pp. 25-48.

Imaeda Yoshirō 今枝由郎. “Chibetto Daizōkyō no Henshū to Kaiban チベット大藏經 の編集と開版 (The Editing and Carving of the Woodblocks For Printing the Tibetan Tripitaka)”. In Iwanami Kōza Tōyō Shisō 岩波講座東洋思想. Tokyo: Iwanami Shoten 岩波書店, 1989, Vol. 11, pp. 326-350. 
Ishihama Yumiko 石濱裕美子. Chibetto Bukkyō Sekai no Rekishi teki Kenkyū チベット 仏教世界の歴史的研究. Tokyo: Tōhō Shoten 東方書店, 2001.

Muli Zangzu Zizhixianzhi Bianzuan Weiyuanhui 木里藏族自治縣志編纂委員會. Muli Zangzu Zizhixianzhi 木里藏族自治縣志. Chengdu: Sichuan Minzu Chubanshe, 1995. Mushi Huanpu 木氏宦譜. Kunming: Yunnan Meishu Chubanshe, 2001.

Pei Yuan 培源, Compiler. Guangxu Yanyuan Xianzhi 光緒鹽源縣志. In Zhongguo Difangzhi Jicheng Sichuan Fuxianzhi Ji 中國地方志集成四川府縣志輯. Chengdu: Bashu Shushe 巴蜀書社, 1992.

Rock, Joseph Francis. The Ancient Na-Khi Kingdom of Southwest China. Cambridge: Harvard University Press, 1947.

Sanzang Shengjiao Xu 三藏聖教序, written by Mu Zeng 木増. In Imaeda Yoshirō 今枝 由郎, Ed., Catalogue du Kanjur tibétain de l'édition de 'Jang Sa tham. Tokyo: International Institute for Buddhist Studies, 1982.

Satō Hisashi 佐藤長. Chūsei Chibeto Shi Kenkyū 中世チベット史研究 (Studies on the Mediaeval History of Tibet). Tokyo: Dōhōsha 同朋舎, 1986.

Tezuka Toshiaki 手塚利彰. “Gushi Han Ichizoku to Zokuryō no Tōzoku Kankei グシハ ン一族と属領の統属関係”. Ritsumeikan Toyō Shigaku 立命館東洋史学, Vol. 2 (1999), pp. 41-76.

Tucci, Giuseppe. Tibetan Painted Scrolls. Rome: Libreria dello Stato, 1949.

Wang Hengjie 王恒傑. Diqing Zangzu Shehuishi 迪慶藏族社會史. Beijing: Zhongguo Zangxue Chubanshe, 1995.

Xu Hongzu 徐弘祖. Xu Xiake Youji 徐霞客游記. Shanghai: Shanghai Guji Chubanshe 上海古籍出版社, 1980.

Yamada Noriyuki 山田勅之. "Mindai Ni Okeru Reikō Nashizoku Bokushi Doshi: chūshin to jishu no hazama 明代における麗江ナシ族・木氏土司一一「忠臣」と 「自主」の間—— (Mu Tusi of the Naxi Ethnic Group from Lijiang during Ming dynasty: between loyalty and autonomy)". Chūgoku kenkyū geppō 中國研究月報， Vol. 61, No. 10 (2007), pp. 1-13.

Yang Fuquan 楊福泉. “Luelun Naxizu He Zangzu de Lishi Guanxi 略論納西族和藏族 的歷史關係”. Yunnan Minzu Daxue Xuebao 雲南民族大學學報, Vol 21, No. 3 (2004), pp. 55-60.

Yu Haipo 余海波 and Yu Jiahua 余嘉華. Mushi Tusi Yu Lijiang 木氏土司與麗江. Kunming: Yunnan Minzu Chubanshe, 2002.

Yunnan Sheng Bianjizu, Zhongguo Shaoshu Minzu Shehui Lishi Diaocha Ziliao Congkan Xiuding Bianji Weiyuanhui 雲南省編輯組・中國少數民族社會歷史調査 資料叢刊修訂編輯委員會. Naxizu Shehui Lishi Diaocha 納西族社會歷史調查. Beijing: Minzu Chubanshe, 2009, Vol. 3. p. 9.

Yunnan Sheng Zhongdian Difangzhi Bianzuan Weiyuanhui 雲南省中甸縣地方志編纂委 員會, Ed. Zhongdian Xianzhi 中甸縣志. Kunming: Yunnan Minzu Chubanshe, 1997.

Zhao Xinyu 趙心愚. Naxizu Yu Zangzu Guanxi 納西族與藏族關係. Chengdu: Sichuan Renmin Chubanshe, 2004. 


\title{
5 Upland leaders of the internal frontier and Ming governance of western Yunnan, fifteenth and sixteenth centuries
}

\author{
Christian Daniels ${ }^{1}$
}

\section{Introduction}

Since the publication of James C. Scott's controversial The Art of Not Being Governed, scholars have increasingly situated Yunnan within the sprawling region known as Zomia. ${ }^{2}$ The term Zomia refers to a stateless mountainous area that functioned as a place of refuge for ethnic groups attempting to escape encroachment by lowland states. In Zomia, communities preserved their autonomy by resisting incorporation into state administrative systems, avoiding paying taxes and refusing to provide lowland states with labour services. Relatively large polities emerged in Dali, the political and religious centre of Yunnan in pre-Ming times, the most renowned being the Nanzhao (649-903) and the Dali (937-1253) kingdoms, with their capitals beside Lake Erhai. These lowland polities existed within a framework similar to the lowland-upland dichotomy found in the northern mainland of Southeast Asia. After the Ming conquest of western Yunnan in 1382 and until 1574, upland communities remained outside the ambit of the state in a vast mountainous tract known as Iron Chain Gorge. ${ }^{3}$ In this chapter, I investigate why the Ming required nearly 200 years to control these upland communities. Adopting the case of Iron Chain Gorge as a means to begin this discussion, I focus on the agency of the upland leaders in maintaining the autonomy of their communities and analyse why their fierce opposition to outside interference restricted Ming governance of western Yunnan before 1574. The purpose is to examine the extent of upland influence on lowland dynastic power.

The upland communities of Iron Chain Gorge constituted an internal frontier (neidi bianjiang 內邊) because the area they occupied was one over which the Ming could not exercise direct control and one which they could not administer indirectly through hereditary native officials (tuguan 土官). Internal frontiers were not unique to Yunnan. Guangdong, Guizhou and Hunan also had them. We possess no information concerning autonomous communities in western Yunnan during the pre-Ming period. In addition, the scanty sources provide insufficient evidence to delineate the history of these communities during the first 200 years of Ming rule. The establishment of institutions, such as Guards and Battalions 
(weisuo 衛所) for defence, hereditary native officials for the management of ethnic peoples, and a household registration system to define the local population, initiated a state-induced transformation of local society. By examining how the internal frontier centred on Iron Chain Gorge resisted the introduction of these institutions, we can verify differences between lowland and upland societies in this process of transformation and highlight how the tightening of governance by the Ming during the sixteenth century shaped the history of upland communities.

The Mongol-Yuan governed local society in western Yunnan from c. 1256 to 1382 through the agency of the Duan Family General Administrators, descendants of the Dali kingdom royal family. ${ }^{4}$ The Ming abolished this strategy of reliance on a single powerful intermediary, choosing to administer prefectures, sub-prefectures and counties directly through regular imperial bureaucrats (liuguan 流官) and to oversee ethnic peoples indirectly through numerous hereditary native officials. The change to direct administration entailed the registration of the population. However, the complexities of ethnic political power and the region's terrain prevented complete registration and ended up creating three types of administrative status: (1) lowland communities under direct administration, (2) ethnic communities administered by native officials, and (3) autonomous communities inhabiting the internal frontier in upland western Yunnan. In the case of (1), the Ming registered the forebears of today's Bai 白 and other ethnic groups dwelling on the lowlands as tax-paying subjects ( $\min$ 民). For defence purposes, Zhu Yuanzhang, the first Ming Emperor, introduced a new Han in-migrant population into the lowland ethnoscape, garrisoning Han soldiers and their families within the jurisdictions of imperial bureaucrats and native officials. A strong military presence and the direct administration of lowland communities formed the backdrop for local elites, mainly consisting of scholar-officials, to initiate projects to reconstruct local society during the sixteenth century. ${ }^{5}$

Created by the examination system and in many cases having served as imperial bureaucrats, the new Confucian local elite set out to re-shape local culture and religion to accord more closely with Ming norms from the late fifteenth century. Their agenda in the sixteenth century included re-writing local history and reforming ideology and beliefs, a process that Ma Jianxiong describes as social reconstruction. ${ }^{6}$ The inability of the Ming state to penetrate type (2) and (3) communities restricted the range of social reconstruction. Since ethnic communities under the jurisdiction of native officials retained their status as $y i$ 夷, or non-registered barbarian people, the Ming could not classify them as subjects directly paying tax to the state. ${ }^{7}$ Residents in autonomous upland communities remained unregistered, a fact that reflects their ability to isolate themselves from state power. Such communities associated with the main stronghold at Iron Chain Gorge remained largely ungovernable by both imperial bureaucrats and native officials alike until 1574 .

Iron Chain Gorge was a place name of wide application. The area under its influence encompassed a broad upland frontier measuring approximately 200 kilometres in a north/south direction, stretching from the south bank of the 
Jinsha 金沙 River (the upper reaches of the Yangzi River) in the north to Yunnan county 雲南縣 (today's Xiangyun county 祥雲縣) in the south, Binchuan sub-prefecture 賓川州 and Zhaozhou 趙州 in the west, and bordering on Beisheng 北勝 sub-prefecture and Yaozhou 姚州 in the east. Protected by precipitous terrain (see Figure 5.1), Iron Chain Gorge formed a natural barrier separating Dali in the west from Chuxiong in the east.

Historical sources testify that these autonomous communities possessed their own leaders (over twenty), indicating that they did not constitute one of the acephalous upland societies of Zomia envisaged by James Scott. Ming sources refer to them as bandits ( $d a o$ 盜) and outlaws (zei 賊) because they periodically plundered lowland villages, waylaid travellers and terrorised vital communication routes linking Dali with the provincial capitals of Yunnan in the east and Sichuan in the north. ${ }^{8}$ Their disruption of lowland communities under both direct and indirect administration lasted for approximately 200 years.

Autonomous communities also existed on the Miao frontiers (Miaojiang 苗疆) in Guizhou and western Hunan and on the Yao frontier (Yaojiang 猺疆)

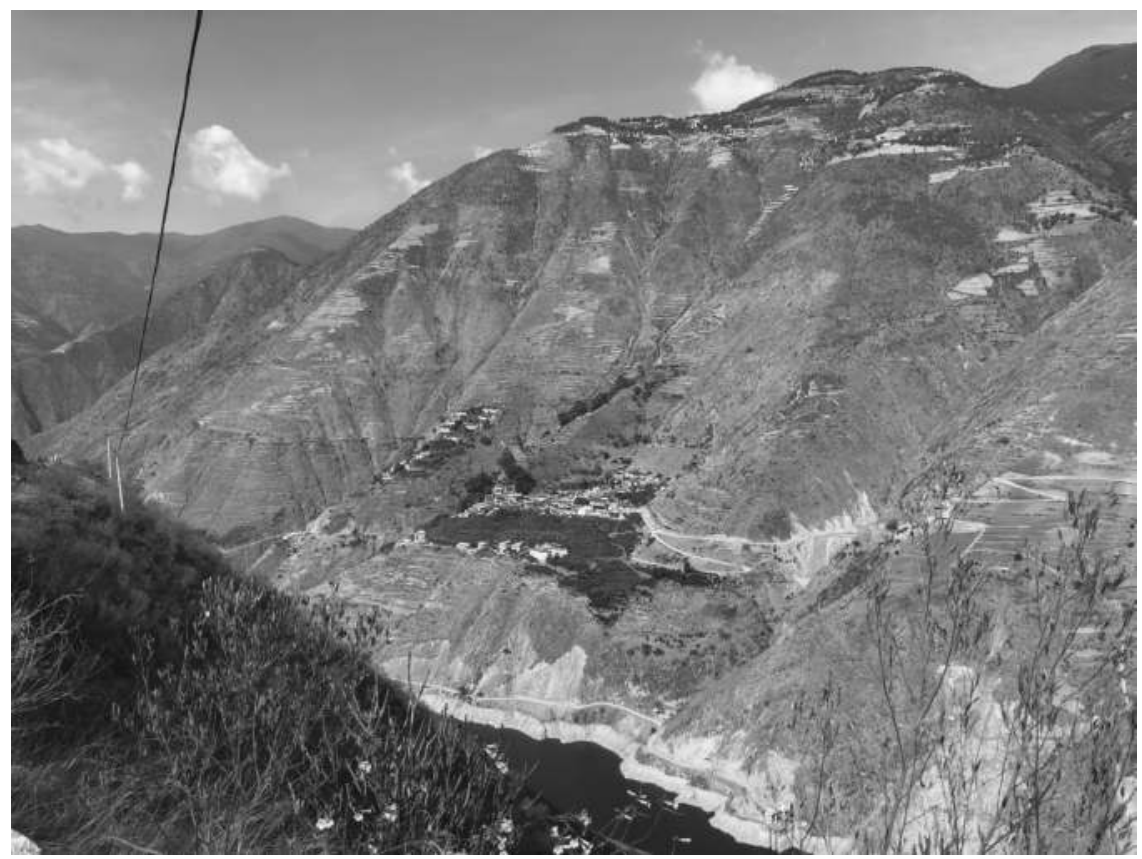

Figure 5.1 The deep gorge of the Yupao River.

The deep gorge of the Yupao River 漁泡江 demarcates the border between Binchuan county and Dayao county 大姚縣. This photo taken from the Dayao side shows the steep mountains on the Binchuan side. Iron Chain Gorge communities lay scattered over the mountains on both sides of the Yupao River until the Ming conquest of 1574.

Photograph: Christian Daniels, 18 June 2019. 
centred at Great Vine Gorge 大藤峽 in Guangdong. In his analysis of the Ming's long wars with the Yao of Great Vine Gorge (c.1446 to 1576), David Faure (2016) identifies three types of village community in the Pearl River Delta: (1) lowland communities populated by registered tax-paying households under the administration of imperial bureaucrats, (2) lowland and upland communities governed by native officials, and (3) communities located within an internal frontier outside the ambit of Ming jurisdiction. ${ }^{9}$ State registration of populations recently brought under direct administration created configurations of registered and unregistered households similar to those in western Yunnan. The expansion of Ming and Qing administration into internal frontier areas challenged the autonomy of upland communities across Southwest China. Historians have studied assimilation and other ethnicity issues in internal frontier areas. ${ }^{10}$ However, they have hesitated to investigate the role played by autonomous communities in defining the extent of state control over local society.

Lian Ruizhi's study on Iron Chain Gorge focuses on elucidating how the Ming incorporated the upland leaders of the internal frontier into the Ming administrative system. She argues that the extension of Ming administration into the margins of the frontier caused the intensification of raiding from the late fifteenth century and culminating in the Ming conquest in 1574. She empirically demonstrates that the Ming split the internal frontier into three separate communities following the conquest. The first constituted a lowland-type community of households registered under the lijia system. The second was a community of native troops (tubing 土兵) subordinate to native police chiefs. While the third community retained its non-registered status, the Ming placed it under the jurisdiction of the Gao Family Native Official of Yao'an 姚安高氏土官. ${ }^{11}$

To investigate the nature of political organisation within the internal frontier and to explain how upland leaders constricted Ming governance in western Yunnan, I address the following questions. First, did upland leaders maintain regimes that involved a degree of political organisation, or did they merely gather followers attracted by the prospect of plunder? Second, why did the Ming require nearly 200 years to conquer Iron Chain Gorge? Third, how did the persistence of an impenetrable internal frontier affect Ming governance of western Yunnan during the fifteenth and sixteenth centuries? By treating Iron Chain Gorge communities as the inhabitants of an internal frontier, I aim to view the interaction between upland political power and Ming governance in western Yunnan from a new perspective. The answers to the research questions will increase our understanding of the process by which the Ming transformed communities in western Yunnan into communities more akin to those of other provinces.

\section{Sources}

Since the upland communities left no documents of their own, information concerning them must be gleaned from accounts written by bureaucrats and literati. I mainly draw on two different sources. Regarding the raiding of lowland areas 
and the reasons for the failure of Ming officials to establish control until c.1574, I largely rely on the writings of Li Yuanyang 李元陽 (1497-1580) and to a lesser extent on memorials by He Mengchun 何孟春 (1474-1536), who served as the Grand Coordinator of Yunnan 雲南巡撫 during the Zhengde era (1506-1521). Li Yuanyang, a native of Taihe county 太和縣 in Dali prefecture, received his metropolitan degree (jinshi 進士) in 1526 and enjoyed a successful bureaucratic career with appointments as the Magistrate of Jiangyin county 江陰 縣, Secretary in the Ministry of Revenue, Investigating Censor and Magistrate of Jingzhou 荊州. After withdrawing from official life in 1542 at the age of 44, he retired to Dali and devoted the rest of his long life to writing prolifically on local history and society. ${ }^{12} \mathrm{He}$ re-interpreted the pre-Mongol-Yuan history of the Nanzhao and Dali kingdoms to accord with the Ming view that Chinese dynastic administration of Yunnan commenced during the Han dynasty. ${ }^{13}$ His retirement coincided with the intensification of raiding by the Iron Chain Gorge leaders. Thus, he wrote as a contemporary of the events he describes.

According to late Ming writer Zhu Guozhen 朱國禎 (1558-1632), Li Yuanyang hailed from an ancient family of "sorcerers" capable of quelling dragons but by his day his family had lost the art. Zhu records that Li's renovation of numerous Buddhist temples in Dali prefecture between 1542 (Jiajing 21) and 1579 (Wanli 7) aimed to prevent flooding wrought by unruly dragons. Apparently, the people around Lake Erhai "dwelt in safety in the past because they worshipped the Buddhist dharma (fofa 佛法), and constructed temples and pagodas 塔 to suppress" these dragons. However, following the abolition of Dali kingdom-style Buddhist dharma by the Ming state, the curse of the dragons returned (long fu zuochong 龍復作崇), causing calamities. Lacking the magical powers of his forefathers, Li Yuanyang chose to subdue the dragons by the renovation of temples. He "restored anew the ruins of the Chongsheng temple and altars (tanyu 壇宇) within the prefecture” 崇聖遺墟及郡中壇宇, 煥然一新. ${ }^{14}$ In remaking local society, Li Yuanyang invoked pre-Ming Buddhist practices, thus revealing deep familiarity with traditions dating to the Mongol-Yuan period. Intimate knowledge of traditional practices aided him in re-writing local history and in re-arranging customs and habits to accord with new sixteenthcentury norms.

As a scholar-official steeped in the traditions of his native Dali, Li Yuanyang was well positioned to update earlier accounts of Mongol-Yuan period local histories, such as the late-thirteenth-century Jigudian shuoji 記古滇說集 (Collected Records of Ancient Dian Stories) by Zhang Daozong 張道宗 and the now lost Bai Gu Tongji 白古通記. ${ }^{15}$ According to Hou Chong 侯冲, Dali intellectuals began to remake Bai identity in Mongol-Yuan times. Therefore, the "updating" of the contents of historical legends by Li Yuanyang can be construed as a continuation of an identity-making process already underway. Megan Bryson considers Li Yuanyang the first Ming writer to furnish detailed accounts of the legend concerning Cishan 慈善 (Charity), also known as Baijie Furen 柏 節夫人 (Lady of Cypress Chastity), a goddess associated with Baijie Shengfei 白潔聖妃 (Holy Consort of White Purity), whom Dali kingdom-period Buddhist 
ritual texts depicted as a consort of Mahākāla. ${ }^{16}$ Bryson argues that both local and non-local scholar-officials altered the stories of the goddesses to accommodate the changing concepts of gender, particularly the chastity cult, espoused by the Ming and Qing states. ${ }^{17}$ This example testifies to the contribution of Li Yuanyang's literary activities to the construction of a new identity and reflects the enthusiasm of intellectuals for reform. Li Yuanyang was not the only local scholar-official who attempted to reconstruct local society to suit the changed circumstances of the mid-sixteenth century. Lian Ruizhi observes that Yang Shiyun 楊士雲 (1477-1554) advocated reform of marriage, burial and ritual practices to align local customs with Ming norms. ${ }^{18}$ Scholar-officials became engines for generating new standards of knowledge while local village elites served as the stewards of their thought who implemented change. The process termed social reconstruction by Jianxiong Ma impinged on all aspects of social life.

The only Ming source that delineates the contours of the internal organisation of upland society is the Biographies of Luo Si and the Various Barbarians of Iron Chain Gorge 鐵鎖箐羅思諸夷列傳 (hereafter Biographies), which is included in the Wanli Wugong Lu 萬曆武功錄 compiled by Qu Jiusi 篗九思 (1546-1617) in 1612. ${ }^{19}$ Biographies provides a detailed account of the events surrounding the large-scale military campaign of 1573/74 led by Censor-in-chief Zou Yinglong 鄒應龍 (who received the metropolitan degree in 1556). This source records the number of troops deployed, the strategy of the offensive, and the numbers of casualties and captives. It also describes in detail the planning and execution of the campaign. Despite its decidedly pro-Ming stance, it provides information concerning the history and organisation of upland leaders collected by bureaucrats.

\section{Ten self-proclaimed kings}

On the eve of the campaign of $1573 / 74$, the political organisation within the internal frontier (see Map 5.1) consisted of an alliance of ten self-proclaimed kings. Luo Si 羅思, an ethnic headman (huotou 火頭), played a central role in the formation of this alliance. Biographies records the genesis of the Ten Kings as follows. In the beginning, it was Luo Qinkuai 羅勤快, a Company Commander (Baifuzhang 百夫長) stationed with troops at Red Rock Cliff, who urged the internal frontier leaders to proclaim kingship. However, he soon abandoned the idea because of opposition by Luo Si and Luo Ge 羅革, who thought it “wildly ambitious, and detrimental to our main objectives 狂妄沮吾大事”. However, these leaders changed their minds after a shaman (wuren 巫人), Li the Immortal 李仙子, described as "adept at magic and deluding people", announced after a prophetic vision that "the life force ( $q \mathrm{i}$ 氣) of a king lies in the gorge". According to Li's forecast, "a king is sure to rise to rule over Nanzhong 南仲 [today’s Yunnan] (箐中有王者氣，此必有興者，當制南仲矣)”. Certain that their time had finally arrived, the ten upland leaders, including Luo Si and Luo Ge, themselves proclaimed "we possess Nanzhong in the present age, 


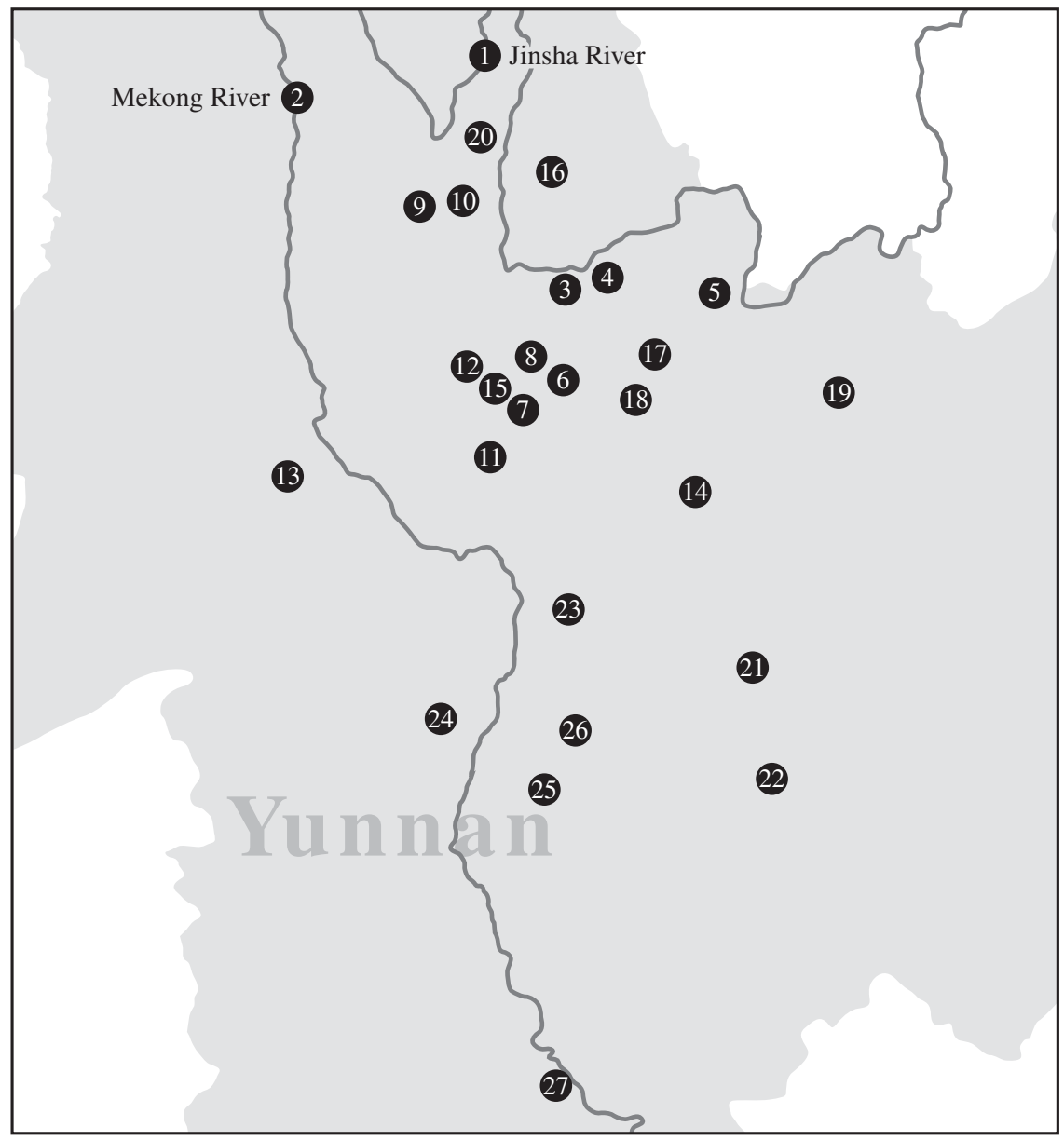
(1) Jinsha River 金沙江
10 Heqing 鶴慶
19 Wuding 武定府
(2) Mekong River 瀾滄江
(11) Menghua 蒙化
20 Lijiang 麗江
(3) Red Rock Cliff 赤石崖
(12) Dali 大理
21 Xinhua 新化
(4) Iron Chain Gorge 鐵索箐
13 Yongchang 永昌
22 Yuanjiang 元江府
(5) Juque 苴卻
(14) Chuxiong 楚雄
23 Jingdong 景東
6 Nidian 你甸
(15) Zhaozhou 趙州
24 Meng Mian 猛緬
(7) Yunnan 雲南
8 Daluo Guard (Binchuan)
16 Lancang Guard (Beisheng)
25 Weiyuan 威遠土州 大羅衛/賓川 瀾滄衛 / 北勝州
(17) Dayao 大姚
9) Jianchuan 劍川
18 Yaozhou 姚州 (Yao’an)
26 Zhenyuan 鎮沅府
27 Cheli (Sipsong Panna) 車里宣慰司

Map 5.1 Internal frontier and centres of administration in western Yunnan, 1582. 
twenty generations after Meng Huo”孟獲二十世後, 當世有南仲”. Assuming the title "the skyward soaring, iron-faced ten great kings" (chong tian tiemian shi dawang 沖天鐵面十大王), they appointed Yang Guisan 楊桂三 and others as ministers (xiang 相). In addition, Yang Che 楊撤, the son of Yang Guisan, served as the great general. "Making tallies and casting seals of office", warriors escorted the leaders when travelling "as if they were kings". ${ }^{20}$ Inspired by the legend of Meng Huo, the ten leaders embraced the idea of kingship. Therefore, the question arises whether this new ideology changed the original configuration of political power within the internal frontier.

Previous research has demonstrated that political power in upland societies typically lay in the hands of numerous individuals and that although certain of them may have wielded more power than others depending on circumstances, particularly in emergencies, no single person enjoyed life-long paramount leadership. ${ }^{21}$ The appointment of ministers to administer and generals to command military forces as well as the taking of tallies and casting of official seals creates a semblance of unified political power. However, rather than indicating substantive change, these acts may have merely reflected a desire to enhance prestige by displaying Chinese statecraft practices. It seems that the concept of royalty did not completely replace former structures, and, in essence, the political organisation of the Ten Kings continued as an alliance of leaders.

Jianxiong Ma argues that by invoking Meng Huo as a key symbol, the Ten Kings articulated their belief that external powers, such as the Ming state, were incapable of governing them. Explaining why the Ten Kings chose Meng Huo, Ma maintains that their claims to descend from him arose in the context of the replacement of the old image of the Nanzhao King with a new one of Zhu Geliang 諸葛亮 at Iron Pillar Temple 鐵柱廟 in Midu 彌渡 and the spread of the construction of Zhu Geliang temples. ${ }^{22}$ Here, to investigate different possible interpretations, I scrutinise the original sources that record encounters between Meng Huo and Zhu Geliang. I argue that from the standpoint of internal frontier leaders Meng Huo can be construed as a protector of Yunnan from Chinese dynastic power.

Meng Huo was an indigenous leader in Yunnan during the Three Kingdoms period 三國 (220-280), at the time when the Shu kingdom 蜀國 held suzerainty over Nanzhong. According to the written version of the story, Meng Huo finally submitted to the resourceful strategist of Shu, the renowned Zhu Geliang, in 225 (Jianzhou 建周 3) after being captured and released seven times (qiqin qizong 七擒七縱). Following his pledge of allegiance, Zhu Geliang returned to Shu, leaving some troops to safeguard against future unrest. ${ }^{23}$

To Chinese readers, this story illustrates the acumen of Zhu Geliang in overcoming an ethnic leader through superior strategy: he attained victory without heavy fighting. The Sun Zi Bingfa 孫子兵法 encapsulates the ultimate stratagem of warfare in the phrase "a hundred victories in a hundred battles is not the best of the best; bringing the troops of others to their knees without battle is the best of the best" ${ }^{24}$ Zhu Geliang triumphed by stabilising Nanzhong without waging full-scale war, a tactic that preserved his military resources for fighting the 
kingdom of Wei 魏國 in the north. However, one source which articulates the perspective of Nanzhong gives a completely different picture, i.e., that it was Meng Huo who outmanoeuvred Zhu, not the other way around. Historical evidence to support this notion appears in the Han-Jin Chunqiu 漢晉春秋 (Spring and Autumn between the Han and Jin Periods) by Eastern Jin-period 東晉 (317-420) writer Xi Zaochi 習鏊齒 (died 384). According to the Han-Jin Chunqiu, Zhu Geliang withdrew all his troops and officials due to the difficulties of governing Nanzhong: ${ }^{25}$

If we leave outsiders, then we must leave troops, but if we assign troops they will have no food. This is the first reason for not being easy to govern. In addition, we have recently defeated the barbarians ( $y i$ 夷), and their people have been killed. Disasters will certainly arise if we leave outsiders [Shu officials] without assigning troops. This is the second reason for not being easy to govern. Again, petty officials ( $l i$ 吏) have repeatedly transgressed by terrorising and killing (feisha zhi zui 廢殺之罪), and the local people detest the serious nature of their crimes (xinzhong 夓重), so if we assign outside people, [the local people] will never trust them. This is the third reason for not being easy to govern. This is why now I want to establish general control (gangji 綱紀) and to some degree stabilise relations between barbarians and Han [dynasty subjects] so that we will not have to station troops and transport grain.

According to this version, the failure of Zhu Geliang to establish direct administration over Nanzhong can be construed as a victory for Meng Huo. It was irrelevant that unstable local political conditions and insufficient numbers of troops and grain supplies made it prudent for the quick-witted Zhu Geliang to appease Nanzhong rather engage in warfare. For indigenous people, his cleverness did not matter. It was Zhu's ultimate withdrawal that counted. Retreat signalled triumph for Meng Huo and underscored the fact that in the end he had succeeded in protecting his land and people from outside interference. By interpreting events this way, Meng Huo emerged as the champion. A home-grown leader had prevailed over a strategist from distant lands.

I cite the Han-Jin Chunqiu version not to argue for a new reading of the historical events, but to illustrate that some literary sources recorded nonconventional interpretations of Meng Huo. According to Biographies, Meng Huo was a model for upland leaders. Therefore, by claiming to be reincarnations of Meng Huo, the Ten Kings identified themselves as successors to this historical legacy and expressed their resolve to oust the Ming from the internal frontier. By invoking this indigenous historical figure, the Ten Kings created an ideology that re-positioned them vis-à-vis the Ming state and emboldened them to believe that, similar to Meng Huo, they too would be protected from outside governance by the difficult terrain of the internal frontier.

These concepts of kingship emerged among communities in the internal frontier against a backdrop of mounting interference from Ming bureaucrats and 
native officials. The Ming originally appointed two local men as native police chiefs as early as $1383^{26}$ but only achieved a strong military presence near the internal frontier after the founding of Daluo Guard 大羅衛 and Binchuan subprefecture 賓川州 in 1494. These measures were aimed at curbing raiding and at governing the registered households relocated to newly founded Binchuan subprefecture from Taihe county 太和縣, Zhaozhou 趙州, and Yunnan county 雲南 縣. In addition, the Ming established a Military Defence Vice-Commissioner 兵 備副使 to oversee several areas surrounding the internal frontier in $1499 .{ }^{27}$ Luo Si and Luo Qinkuai understood Ming intentions. They both held minor official positions in the very institutions that the Ming established to control the internal frontier. As a Company Commander, Luo Qinkuai may even have been responsible for restraining his own people from exiting the uplands. However, as Lian Ruizhi has shown, the military build-up failed to safeguard lowland populations. On the contrary, the presence of Ming troops only hardened the resolve of upland leaders to defend their autonomy and tighten alliances among themselves. Thus, the build-up resulted in an intensification of raiding during the sixteenth century. ${ }^{28}$

Attempted governance by two native officials increased the complexity of relations between upland leaders and Ming bureaucrats. Biographies records the autonomous nature of the internal frontier, remarking that no part of it owed labour service (yishu 役屬) to the Ming before the late fifteenth century. ${ }^{29}$ However, the situation altered after the Native Prefect of Yao'an prefecture, Gao Feng 高鳳,,$^{30}$ and the Native Vice Magistrate of Yaozhou, Gao Chun高椿, ${ }^{31}$ began to administer the eastern fringes around Juque 苴卻 (in today's Yongren county 永仁縣) from the Hongzhi era (1488-1505) onwards. Although both native officials took turns managing this marginal area, neither established an exclusive jurisdiction (zhuanshu 專屬). During the Zhengde reign (1506-1521), the area came under Gao Bi 高弦 of Yaozhou. ${ }^{32}$ However, during the Jiajing reign (1522-1566), jurisdiction reverted to Yao'an prefecture, with Gao Qidou 高齊斗 being placed in charge. ${ }^{33}$ With the dismissal of Gao Qidou from office for criminal offences, the task fell to Gao Hu 高鴊. After the death of Gao Hu, Qidou's son Gao Qin 高欽 exercised jurisdiction. In approximately 1567-1569, Gao Qin 高欽 and his younger brother Gao Diao 高釣 became embroiled with upland leaders in a deadly struggle for the leadership of another position, the Native Prefect of Wuding 武定.

This struggle may have prompted upland leaders to proclaim kingship. Therefore, I will briefly describe it. The Native Prefect of Wuding was a hereditary position passed through the Feng family line 鳳氏. Madame $\mathrm{Qu}$ 翟氏, who had been appointed Native Prefect in 1537 after the death of her son Feng Zhao 鳳 詔, became dissatisfied with the behaviour of Suo Lin 索林, the wife of Feng Zhao 鳳詔, who succeeded her as Native Prefect in 1563. Madame Qu mobilised troops from native officials in neighbouring Guizhou and Sichuan in an attempt to install her adopted son, Feng Jizu 鳳繼祖, as a replacement for Suo Lin. The conflict between the two women triggered prolonged regional warfare. ${ }^{34}$ Gao Qin drew the internal frontier into this deadly conflict by instigating upland leaders to fight for the cause of Feng Jizu. He persuaded them to deploy 
"the bandits from the gorges (qingzei 箐賊)" to attack Menghua prefecture. These forces were dispatched by Gao Qin’s “arrogant bondservant (hanpu 悍 (僕)" Gao Xiaosan 高小三, who administered the eastern fringe of the internal frontier at the time. After the execution of Feng Jizu, Gao Xiaosan was dismissed from office, and, according to Biographies, it was from this time onwards that "the various leaders at Iron Chain" became "increasingly active, cruel and disorderly 益剽架亂”. ${ }^{35}$ The rebellion by Feng Jizu broadened the range of alliances to encompass upland leaders from throughout the internal frontier of western Yunnan. ${ }^{36}$

These intrigues alerted upland leaders to the dangers inherent in associating with native officials. The events demonstrated that appointees to jurisdictions at the margins of the uplands could manipulate upland leaders for their personal benefit, underscoring the largely perfunctory nature of administrative control by the Gao Native Prefect. The Gao Native Prefect failed the Ming on two accounts: first, by neglecting to avert the build-up of political and military power within the internal frontier; second, by not preventing his family members from colluding with upland leaders. Such plotting resulted in certain members of the Gao family turning against the Ming in 1573. Biographies records that Gao Xi 高熙, the family member responsible for handling upland affairs, secretly dispatched Luo Mingfeng 羅鳴鳳, a Company Commander (Baifuzhang 百夫長) with 1,400 of his own men to help internal frontier leaders fight against the Ming. ${ }^{37}$ The relationship between members of the Gao family and internal frontier leaders indicates collusion for mutual benefit rather than top-down administration. In reality, the Gao Native Prefect exercised limited control over the internal frontier, and the machinations of his family members may have emboldened upland leaders to be more receptive to a millennial ideology that promised protection of their autonomy.

\section{Ethnic groups and villages within the internal frontier}

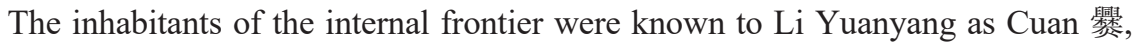
an ethnonym of wide application that implied a variety of ethnicities. Remarking that these inhabitants "are not all of the same stock (zhongzu 種族), but comprehensively known as Cuan", Li described them as "tough and dauntless (guanghan 獷悍) by nature", and noted that lowland people avoided association with them due to their "regular use of sturdy cross-bows with poisoned arrows that resulted in instant death when hit". 38

Table 5.1 lists twenty-four leaders within the internal frontier. Biographies uses the common ethnic designation of the Iron Chain Gorge group as "wild unregistered Luoluo 猓玀野夷 [forebears of today's Yi 彝]” and classifies the twenty-three other leaders as "all mostly unregistered Boren 整人 [forebears of the Bai 白] and Luoluo". Therefore, constituent groups of the internal frontier comprised a multi-ethnic mix of Luoluo and Boren. ${ }^{39}$ The Gao Native Prefect failed to transform them into his obedient subjects, let alone register them as tax-paying subjects of the Ming. They patently remained outside the orbit of control by both native officials and the Ming state alike. 
Table 5.1 Leaders in the internal frontier, c.1572-1573

\begin{tabular}{lll}
\hline Number & Name of Sub-prefecture/County & Name of Leader's Territory \\
\hline 1 & Yao'an & Iron Chain Gorge 鐵鎖等 \\
2 & Binchuan & Red Rock Cliff 赤石崖 \\
3 & Binchuan & Tanglang 螳螂 \\
4 & Binchuan & Gudi 古底 \\
5 & Binchuan & Wulong Ba 烏龍壩 \\
6 & Yunnan & Dabona 大波那 \\
7 & Yunnan & Nidian 你甸 \\
8 & Yunnan & Hedian 和甸 \\
9 & Yunnan & Chuchang 楚腸 \\
10 & Yunnan & Gezuo 各左 \\
11 & Yunnan & Muchala 木茶喇 \\
12 & Yunnan & Dasong Ping 大松坪 \\
13 & Yunnan & Qianglang 羌浪 \\
14 & Yunnan & Jinqie 金且 \\
15 & Yunnan & Edala 俄打喇 \\
16 & Yunnan & Xiao Chala 小茶喇 \\
17 & Dayao & Lamo 喇摩 \\
18 & Dayao & Waining 歪寧 \\
19 & Dayao & Mozhi 摩只 \\
20 & Dayao & Juzhi 苴只 \\
21 & Dayao & Moduola 摩朵喇 \\
22 & Dayao & Xiao Chishi 小赤石 \\
23 & Dayao & Anila 阿你喇 \\
24 & Dayao & Piaoju 漂䓝 \\
\hline
\end{tabular}

Source: Tiesuoqing Luo Si Zhuyi Liezhuan 鐵鎖等羅思諸夷列傳), Qu Jiusi 䨉九思, Wanli Wugong $L u$ 萬曆武功錄, p. 568 b.

Mid-sixteenth-century estimates of the number of upland villages within the internal frontier range from seventy to eighty. ${ }^{40}$ The territories of the twentyfour leaders extended across the boundaries of two counties and one subprefecture (Table 5.1). ${ }^{41}$ Excluding Iron Chain Gorge, which fell under Yao'an, a breakdown of the others by sub-prefecture/county indicates there were four leaders within the jurisdictions of Binchuan, eleven in Yunnan (today's Xiangyun 祥雲) and eight in Dayao. These data reveal two facts regarding the extent of upland political power. First, Iron Chain Gorge already maintained alliances with upland leaders over a broad area before the foundation of the Ten Kings alliance. Second, the territories of certain leaders included stretches of the lowlands as well as upland tracts. The terms $b a$ 壩 (a flat or undulating plain surrounded by mountains) and dian 甸 (flatland only) in toponyms no. 5 Wulong Ba, no. 7 Nidian and no. 8 Hedian refer to land suitable for lowland-style cultivation. Therefore, we can conclude that the upland leaders held sway over these three locations in Binchuan sub-prefecture and Yunnan county. 
Although Binchuan sub-prefecture was founded in 1494 (Hongzhi 7) for the specific purpose of preventing raiding, leaders of the interior frontier continued to claim authority over lowland strips nearly eighty years later. As shown later, they raided lowland societies adjacent to the uplands in parts of Binchuan up to 1573 .

\section{3/74 campaign against the internal frontier}

In a memorial to the throne dated 7 July 1479 (Chenghua 15/6/18), Mu Cong 沐琮, Regional Commander of Yunnan 雲南總兵官, reported the success of the military campaign against Wang Tonghai 王通海 and other barbarian bandits (manzei 蠻賊) of Iron Chain Gorge, who "assembled in large numbers to raid and to plunder 犚聚劫掠”. Ming forces captured 309 people, beheaded 139 and took 133 as captives. These figures do not include the exceptionally large numbers of those who died jumping off cliffs and starving to death from deprivation. ${ }^{42}$ However, this campaign failed to eradicate raiding, and, as noted earlier, depredations escalated in the sixteenth century. The campaign of 1573/74 was far larger and far more decisive than that of 1479. It resulted in a 400 per cent increase in the number of individuals captured alive and a six-fold increase in severed heads. In the subsequent section, I begin with a brief outline of the campaign and the role played by native officials and then proceed to examine the infrastructure for governing conquered uplands in the aftermath, particularly the construction of government offices.

\section{Account of the campaign}

According to Biographies, the campaign meticulously planned and co-ordinated by Zou Yinglong lasted for two months, from 8 November 1573 (14 day/10 month/Wanli 1) until 14 January (22 day/12 month/Wanli 1) $1574 .{ }^{43}$ Zou Yinglong completed positioning troops at the four cardinal points of the internal frontier to block escape routes by 21 November 1573 (27 day/10 month/ Wanli 1). Then, he travelled to the front line in disguise to avoid upland leaders learning of his plans through their connections with local officials. Following military tradition, on 29 November 1573 (6 day/11 month/Wanli 1), Zou led officers and troops in making sacrifices to the god of the commander's banner (qidao zhi shen 旗素之神). They consecrated the banners and drums (xin qigu 鱟旗鼓) with the blood of a beheaded traitor named Yang Xiande 楊獻德. ${ }^{44}$ Zou launched the attack after the completion of this ceremony and required approximately one and a half months to overcome the strongholds. Ming forces apprehended several of the Ten Kings and other officials, such as Luo Qinkuai 羅擒快, Yang Guisan 楊桂三, the General Yang Che 楊撤 and Li the Immortal, but failed to capture the central figures Luo Si and Luo Ge. The latter may have been among the several hundred who perished from starvation while fleeing to the Jinsha River. The Ming army captured 1,287 men and women and severed a total of 836 heads. 
Native officials provided most of the combat troops. Table 5.2 reveals that Zou Yinglong mobilised 6,400 soldiers from native official jurisdictions in today's Chuxiong, Lijiang and Dali prefectures to fight at the front line in mountainous terrain. Biographies does not mention Ming army regulars serving within the internal frontier although it records in detail how the Ming deployed native troops. When commanded by native officials, Ming bureaucrats served as supervisors. However, when native officials did not come in person, Ming bureaucrats served as both commanders and supervisors. The total number of troops personally led by native officials only amounted to 2,500, less than half. Certain native officials were prevented from appearing by other duties. For instance, Zou Yinglong instructed Gao Chengzu 高承祖, the Native Official of Beisheng 北勝, to lead his own troops at the Jinsha River to prevent escape via the northern route. ${ }^{45}$ To this end, he appointed $\mathrm{Li}$ Chaochen 李朝臣 and $\mathrm{Li}$ Zhongxing 李中行 to command another 1,000 men dispatched by Gao and assigned Hu Song 胡崧, the Prefect of Yao'an, to supervise them. Therefore, if we add the native official troops mobilised to guard escape routes, the actual count exceeds the 6,400 men recorded in Biographies..$^{46}$ For the conquest of Iron Chain Gorge, the Ming relied on the mobilisation of large numbers of native official troops. This approach was common in the southwest, where native officials provided 70 per cent of the 240,000 troops mobilised to quell the massive rebellion at Bozhou 播州 by the incumbent Native Official Yang Yinglong 楊應龍 in $1599 .{ }^{47}$

\section{Construction of administrative centres within the internal frontier}

Establishing an intra-structure within the internal frontier was essential for effective administration after the conquest. In the past, the Ming had stationed bureaucrats in the lowlands but achieved little success in extending control into the internal frontier. Li Yuanyang enthusiastically endorsed the erection of bureaucratic edifices. As early as $c .1559$ (Jiajing 38), he applauded the construction of a strategically located official residence-cum-office (gongguan 公館) at Juque 苴卻 in Yao'an. ${ }^{48}$ Bureaucrats built this edifice within a wall attached to a Buddhist temple on a thoroughfare at the eastern margins of the internal frontier. Li Yuanyang emphasised that by "raising the gates high and making the doors magnificent", bureaucrats were now able "to overawe traitors and to provide the honest and the good with something reliable (高其閈䦎, 壯其門閭, 以威反側, 以怙善良)"; he remarked that fortified within an encircling wall, the building complex "resembled a small city". ${ }^{49}$ Li clearly viewed bureaucratic edifices as instruments for impressing upland peoples and as a means to display the might of the Ming while cowing the vanquished into submission. He recognised their multi-purpose functions. In his own words, "normally used for hearing court cases, they can serve as places for commanding troops in times of emergency（建之棟宇，居常為聽訟之所，應變為治兵之地)" ${ }^{50}$ These structures doubled as administrative and military bases, and it was for this reason that he regarded their construction as an essential expenditure for good governance. 


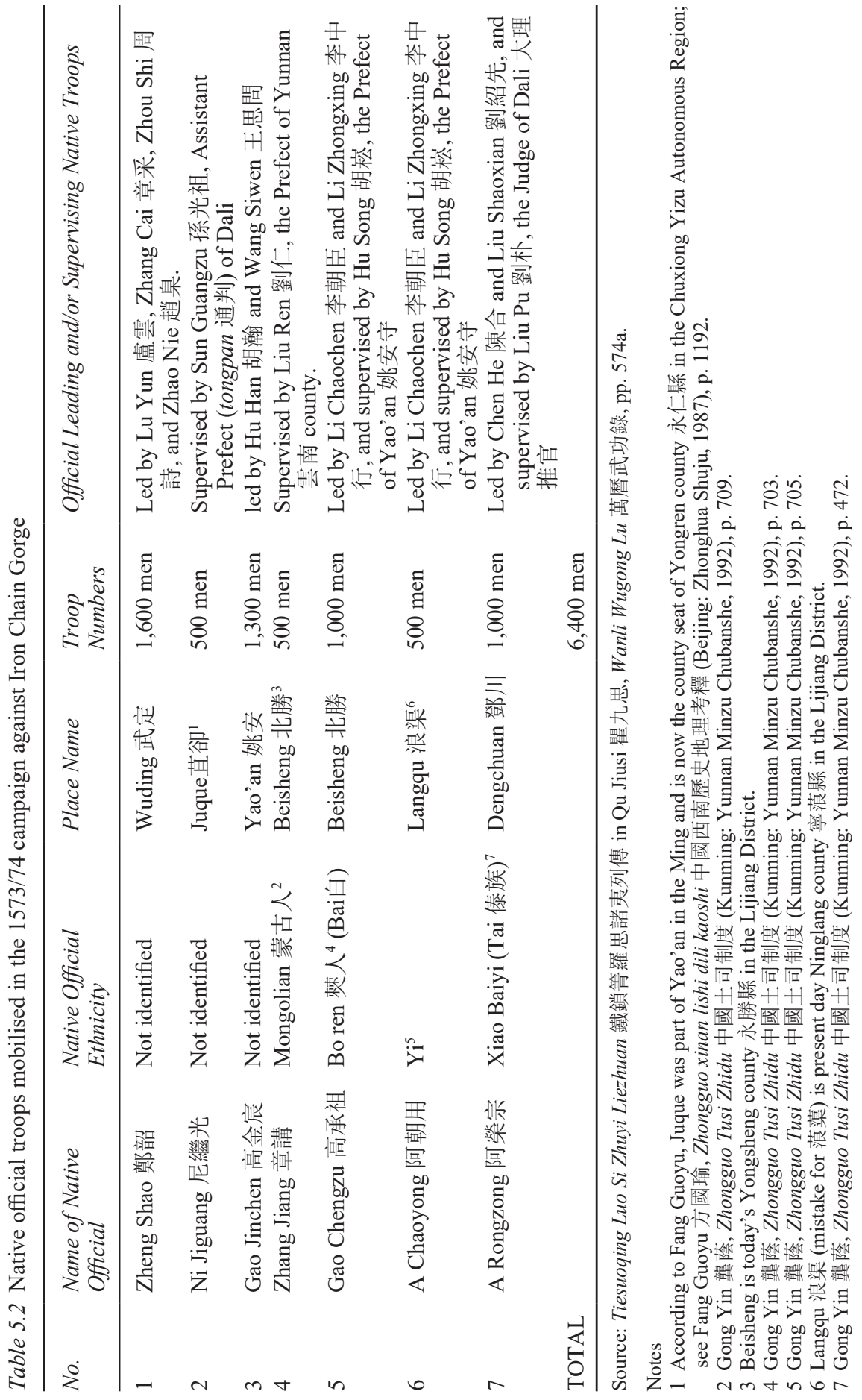


Li Yuanyang wholeheartedly supported the erection of a government office at Yangbi 漾濞 in 1574 (Wanli 2) as a strategic base for administering the vast uplands overlapping the three prefectures of Dali, Menghua and Yongchang. He explained his logic as follows: ${ }^{51}$

Since its establishment during the Jiajing reign period, only three people have been appointed as Commandant of the Jinsha and Lancang rivers. ... Prior to the time of the incumbent Li Hou 李侯, officials possessed no permanent office. They travelled back and forth between the three prefectures [of Dali, Yongchang and Menghua]; their horses never rested their hooves, and officials never sat [in one place] long enough to warm their seats. Affairs appeared to be executed exceptionally diligently, but [always] at lightning speed, as fast as the autumn wind blows away fallen leaves. Then, why were officials unable to thoroughly investigate evil elements and hidden conspirators? It was due to the lack of a residence from which to arrange [official affairs] and a shortage of spare time. Troops were not well organised because there was no residence from which to command them; there was no spare time to [investigate] affairs because official business was handled from horseback ...

... This official has to lead troops on campaigns of one thousand $l i$ in order to defend fortresses, to control barbarians ( $y i$ 夷) far away at the margins and to subdue evil elements and conspirators close at hand. Clearly, the duties are not light. By simply having him roam around the uplands, without any administrative office to work from, how can he sit down to plan negotiations and watch over [an area as extensive as] one thousand $l i$ ? Lack of a residence and shortage of spare time are precisely the reasons why [office buildings must be constructed].

To transform upland society to accord with Ming norms, officials needed to reside at permanent offices to administer and supervise newly incorporated ethnic groups. Therefore, the erection of offices constituted an integral part of Li Yuanyang's agenda for establishing administration over the internal frontier. In addition to functioning as organs for administrative, legal and military control, the offices simultaneously served as symbols of Ming triumph. It was only through on-the-spot administration that Ming bureaucrats could prevent upland communities reverting to their former ways.

\section{Extent of Ming control over the internal frontier}

Organised raiding activities by upland leaders severely disrupted lowland life in western Yunnan during the fifteenth century. Although the campaign of c.1479 marked an attempt to resolve this problem, it failed to curb raiding in the long term. Therefore, why did imperial bureaucrats require until 1573, nearly 190 years after the conquest of Dali, to conquer the internal frontier stronghold at Iron Chain Gorge? By way of answer, first, I demonstrate the scale of disruption, and then, I investigate the reasons for the Ming failure to take decisive action. 


\section{Raiding in the sixteenth century}

Leaders of the internal frontier raided broadly over the lowlands of three prefectures during the sixteenth century: Menghua, Yao'an and Chuxiong. ${ }^{52}$ In 1555 (Jiajing 34), Li Yuanyang lamented raiding as the terrible curse of Yunnan. remarking, "half of the province, has suffered from the calamities of bandits from the various gorges in Binchuan (賓川諸箐之盜, 滇西半省被其 患)"53 (see also Figure 5.2). The raiding impinged on many aspects of lowland life: ${ }^{54}$

There are twenty-odd barbarian bandit villages between Iron Chain Gorge in Yao'an and Red Rock Cliff in Binchuan. Armed with long spears and sturdy crossbows, the bandits rove, pillaging villages and military colonies (cuntun 村屯). Their raiding has become increasingly audacious (chi 熾) over the past two hundred years; they murder people on major thoroughfares, and do not flinch at flags and banners [of imperial troops]. They capture the

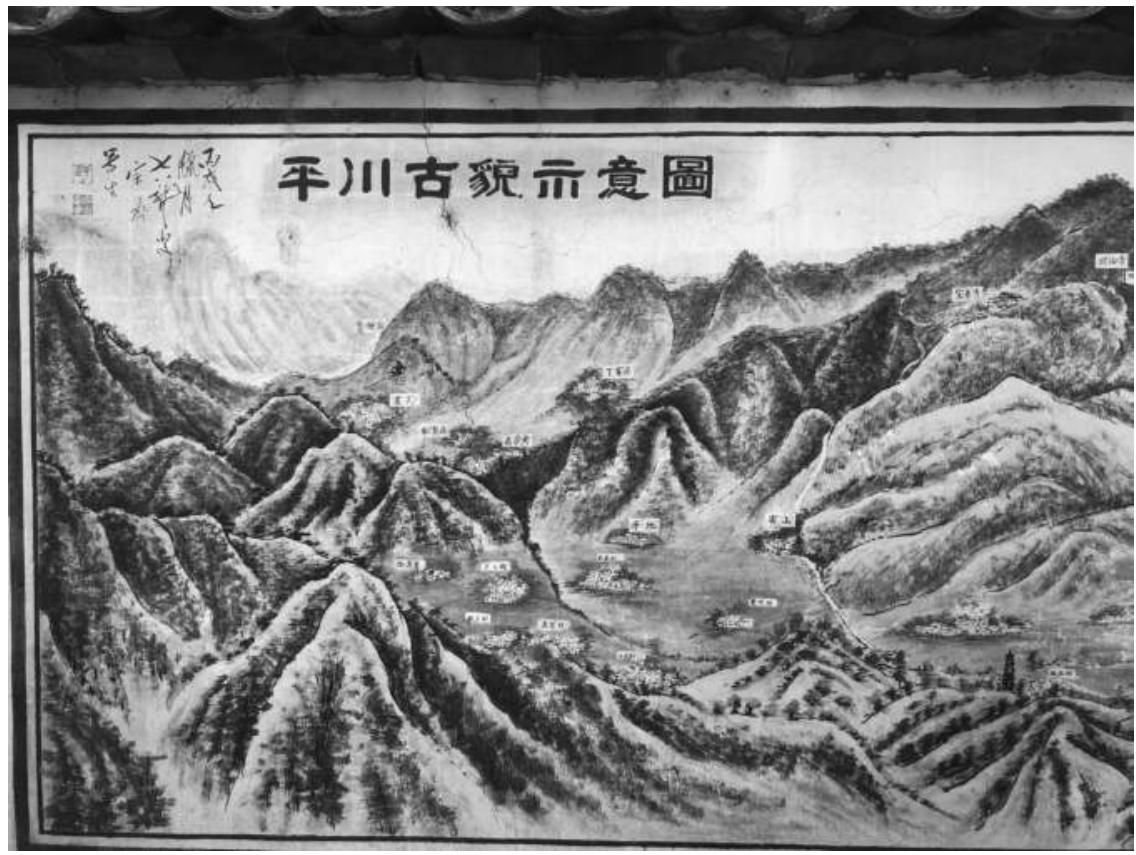

Figure 5.2 Sketch map of the mountains of Iron Chain Gorge.

Painted on a wall in Pingchuan 平川 (Binchuan county), this sketch map illustrates the precipitous mountains of the internal frontier in the background and settlements under Ming jurisdiction scattered at different elevations throughout the lowlands in the foreground. Painted in 2006 by a local man named Zong Qi 宗齊, this mural bespeaks the longevity of the lowland memories of raiding by Iron Chain Gorge inhabitants over 450 years after the Ming conquered this internal frontier.

Photograph: Christian Daniels, 22 June 2018. 
households of scholar-officials and common people, advance on walled cities and rampage everywhere, so no one dares to touch them.

Li Yuanyang documented the escalation in the scale of cruelty and despoliation since the fifteenth century: ${ }^{55}$

In the beginning, they robbed and plundered merchants, then they torched and captured villages and military colonies (cuntun 村屯), and their brethren have grown by the day. Possessing a penchant for killing people wherever they pass, they run wild doing as they please on the major thoroughfares. Carriages carrying officials cannot travel to the prefectures and counties without protection from command posts (shao 哨) and lookouts (wang 望). Outside walled cities, all people who have over one foot (chi 尺) of housing and agricultural land pay [grain tax] in rice, or wheat, so they beg the raiders for special dispensation. [If they have no grain] the raiders take at will household effects, clothes, felt, cotton, silk, fowls and pigs, and nobody dares to interfere, even in the smallest way. Great disaster immediately befalls anyone who defies their wishes. Over the past two hundred years, all strategies have involved constant deployment of troops to guard against them, and continual increases in taxes payable in grain (liang 糧) to meet the costs. Also, relying on native officials (qiuzhang 酋長) we have recruited native troops to deal with them. Government coffers suffer losses daily, while the bandits benefit from robbery day by day.

By the sixteenth century, Ming officials understood that things had slipped beyond their control. They had never exercised effective authority in the internal frontier, mollification policies had failed, and now they were losing some of the lowlands, while the raiders stood to gain everything at their expense. ${ }^{56} \mathrm{Li}$ Yuanyang's account documents the extent to which western Yunnan was riven by the leaders of the internal frontier. Communities near the frontier feared for the safety of their lives and property. When raiders descended to the lowlands, they came to wreck and to steal, to take away all the comfort that villagers had made for themselves. Plundering villagers and waylaying travellers heightened the sense of insecurity. Even officials could not travel without military escorts.

Lian Ruizhi observes that the limiting of upland access to lowland food supplies aggravated the situation in the internal frontier. Traditionally, lowlanders exchanged excess grain with upland communities. With the extension of administration into marginal areas, the lowland populace now had to pay grain tax in kind to the state, an arrangement that diminished the amount of grain available for trade with the uplands. A reduction in food supplies to the uplands caused deprivation in the internal frontier. Alterations to lowland-upland exchange practices precipitated by the introduction of tax-grain obligations compelled upland leaders to raid more frequently and more intensely than before to obtain food. Therefore, as recorded in the passage cited above, raiders 
now plundered for anything of value, i.e., "household effects, clothes, felt, cotton, silk, fowls and pigs", to support their livelihoods. Policies adopted to extend administration towards the upland, such as the mollification of ethnic leaders, the recruitment of native troops (tubing 土兵), establishing garrisons and collecting tax grain had backfired. Rather than stabilising marginal areas, these measures ended up exacerbating tension between the lowlands and the uplands..$^{57}$

Murderous destruction by the raiders was not haphazard. Li Yuanyang makes this point in his Record of Pacifying the Bandits at the Tiesuo River (probably written in 1573): $: 58$

Wet-rice fields at the border in northeast Chuxiong prefecture are fertile, and the people are good and honest. They dwell in expansive houses and have fine clothes for outings, but unable to enjoy ordinary life they all feign simplicity and poverty. Since the place adjoins the Tiesuo river 鐵索川, bandits come and go, pillaging and harming, and they do not enjoy a single year of peace. Residents dash into hiding to evade them, abandoning their livestock and granaries, so when they resume their occupations they start [again] with nothing. They consider themselves fortunate if [the raiders] do not destroy their dwellings. It has been the same every year since the foundation of the prefecture. Those in authority have pitied the hardships of the people and have been agonised by the situation, but the territory of the bandits is expansive, and due to its location at the margins of three prefectures they are able to march unhindered between two sub-prefectures and four counties, ${ }^{59}$ where mountains rise rugged and steep, and gorges run as deep as wells. Shady trees tower high into the sky, and bramble and hazel obstruct roads on dangerous and precipitously high mountains. The location has made it difficult to take any action.

Raiders must have left some houses intact. Without a roof over their heads, villagers would be displaced. To ensure that they stayed, upland leaders had to leave them with resources to recover. In this way, they had something to plunder the next time. Revenue derived from looting spoils, levies and "protection money" helped sustain communities within the internal frontier. Long-term raiding depended on constant access to lowland communities. It was not ad hoc but planned and organised by upland leaders through alliances, such as that of the Ten Kings. Therefore, raiding became even more important as a method of sustenance when the lowland-upland exchange system collapsed.

\section{Factors hindering the elimination of raiding}

Why did the Ming require 200 years to conquer the internal frontier? Multiple factors, many closely related to Ming state policy, were at play. Here, I discuss three of these factors: inaccessibility and state policy, change in lowland-upland exchange, and the attitudes of imperial bureaucrats. 


\section{Inaccessibility and state policy}

Upland communities across Southwest China and Southeast Asia were located distant from the centres of state power in lowland areas. The internal frontier in western Yunnan was no exception, and Li Yuanyang documented inaccessibility as a factor hindering the elimination of raiding. He explained as follows: ${ }^{60}$

Administrative orders do not reach the borders of two adjoining provinces, or the junctures of various prefectures, nor do the carriages of officials pass through these places. Relying on easily defendable strategic positions, [leaders in the internal frontier] gather the multitudes and assemble them into bands, so invariably, fierce monsters (xiongnie 杀㧛) and numerous bandits lurk here.

Rugged terrain prevented bureaucrats from constructing administrative infrastructure within the internal frontier. To prevent intrusion from outside, upland leaders utilised countless "easily defendable strategic points" at the precipitous mountain junctures with provinces and prefectures. In the previously cited Record of Pacifying the Bandits at the Tiesuo River, Li Yuanyang remarks that "the territory of the bandits is expansive" and notes that the upland leaders exploited their location at the margins of Ming administration. This strategy enabled them to target the weak spots in the vulnerable lowlands at the peripheries of Ming control. Alternatively, from their bases, the raiders could easily slip away into mountainous terrain impenetrable to Ming forces. Upland leaders sustained their autonomy by remaining inaccessible. Topography hampered the enforcement of Ming standards of law and order.

Closely co-ordinated operations by upland groups from different strongholds presented insurmountable challenges. In a memorial of 21 June $1521(17 / 5 /$ Zhengde 16), He Mengchun 何孟春 (1473-1536) explained that when sallying forth to raid, the raiders "banded together as kin, and no one could withstand the sharpness of their blades" but "dispersed to live in their hideouts, making it hard to track them down" afterwards.$^{61}$ The guerrilla tactic of disbanding immediately after the completion of concerted action made it even more difficult to trace their whereabouts.

\section{Adjustments to lowland-upland exchange}

We have already noted that the extension of administration into the marginal parts of the internal frontier and food shortages resulted in stronger opposition, compelling upland leaders to raid more frequently and with greater intensity during the sixteenth century. In this section, I provide evidence to support the argument that these shortages resulted from adjustments to lowland-upland exchange arrangements. I attribute the causes of these shortages to the introduction of new land-tax systems and restrictions on trade that accompanied the extension of administration. 
Lowland people traded rice for salt at the margins of the internal frontier during the Ming. Upland peoples supplemented their food supplies through this system of exchange. ${ }^{62}$ According to Li Yuanyang, "unregistered people close to [Yao'an] prefecture known as Luoluo 儸儸, Boyi 整夷, and Sanmodou 散摩都 who are fierce and have a passion for fighting used salt and rice for trading, and small markets (xiaoshi 小市) opened daily, and large markets every five days" ${ }^{63} \mathrm{He}$ also records that "local people treated salt as treasure (bao 寶)" and even named a strategic pass only one $l i$ distant from the [Yao'an] prefectural seat Treasure Pass (Baoguan 寶關) because it served as a vital thoroughfare for transporting salt. ${ }^{64}$ That people used mountain pathways in Yao'an prefecture at the margins of the internal frontier for transporting salt reflects the importance of salt to upland communities. Although common in the lowlands surrounding the internal frontier, this pattern of exchange broke down when the Ming burdened newly conquered areas with the payment of grain tax.

Certain sources mention restrictions on lowland and upland trade during the Jiajing period. In his stele to commemorate the deeds of Jiang Long 姜, Vice-Commissioner of the Lancang Military Defence Circuit 瀾滄兵備副使, Yang Shen 楊慎 (1488-1559) lauded Jiang's courage in venturing into the internal frontier of Yao'an to pacify and soothe (zhaofu 招撫). Yang Shen records the upland people as testifying that food shortages drove them to robbery and stressed that lack of access to Ming bureaucrats deprived them of the means to express their grievances: ${ }^{65}$

Previously, when we went down from the mountains [into towns] we were apprehended, and falsely accused of being bandits. Dwelling deep in secluded gorges food was difficult to obtain, so we had no way of seeking survival other than robbery. Since birth we have never seen bureaucrats present at this place, nor have we ever heard of them visiting, so we had no means of making our hardship known.

This stele reveals that lowland peoples stigmatised upland peoples as bandits and blocked their access to grain. Imperial bureaucrats remained unaware that the need for food fuelled raiding because they never set foot in this part of the internal frontier prior to the conquest. The bureaucrats only perceived this causal relationship after visiting upland communities. Therefore, it was the arrival of Ming administration that improved the access of upland residents to markets because the state now treated them the same as the registered populace. Yang Shen applauded the change: ${ }^{66}$

The various barbarians have come out of the gorges to participate in markets and are no different from registered people (bianmin 編民). Travelling merchants journey at night, and outposts (shao 哨) and forts (bao 堡) sleep in tranquillity. This has never been seen during the past hundred years. 
The opening of markets to upland peoples alleviated food shortages, eradicated raiding and brought security. How long this peaceful situation lasted or whether it was merely a fancy of Yang Shen's imagination is irrelevant to my argument. What is relevant is that interference in lowland-upland trade resulted in food shortages among upland residents.

Further evidence for the role of markets appears in a stele by Li Yuanyang that chronicles the conquest of the southwest tract of the internal frontier. Known as A Record of Quelling the Bandits of Binchuan, dated 3 July 1555 (15 day/6 month/Jiajing 34), the stele details the construction of government offices at former bandit lairs (chaolu 巢盧) and the measures designed to transform former raiders into loyal subjects: ${ }^{67}$

We can use these people as our soldiers and educate their young as if they were the same as our own sons. On the outside we can use tax-grain supplies (liangxiang 糧餉) to reward their commendable hard work, while on the inside we can use them to restrain and prevent any evil scheming. We have set up markets (lishi 立市) for them so that they can exchange what they have for what they do not have. We permit them to trade in salt and allow them to transport it on their shoulders and heads. We start fresh and new again, and do not investigate [the past]. With adequate food and sufficient troops, we can also issue orders for the establishment of community granaries (shecang 社倉).

The first measure was the recruitment of upland males to serve as native soldiers (tubing 土兵) to guard against raiding by upland groups from unconquered parts of the internal frontier. The second measure aimed to introduce an exchange mechanism to alleviate food shortages, and the agenda included establishing markets and permitting trade in salt. Lian Ruizhi argues that this stele indicates that the Ming obstructed the rice and the salt trade prior to $1554 / 55$, thereby preventing upland residents from participating in the lowland trading network. ${ }^{68}$ We possess no evidence for the Ming placing a total prohibition on trade with the internal frontier. Thus, the obstruction may have only applied to salt. Restricted access to salt would have deprived upland peoples of essential commodities for trading with lowlanders for rice.

\section{Attitudes of imperial bureaucrats}

In the eyes of Li Yuanyang, the negative attitude of bureaucrats contributed to the prolongation of raiding. Although the strongholds located deep in mountainous terrain presented logistical challenges, that fact in itself was not an insurmountable problem given the large number of troops garrisoned in western Yunnan from the early Ming. In the stele A Record of Quelling the Bandits of Binchuan, Li Yuanyang explained the mind-set of the Ming officials. In view of its importance for my argument, I cite it at length: ${ }^{69}$ 
When considering matters, excessive concern with profit and loss causes people to ignore the crucial in favour of the trivial. If it is clearly an emergency situation, but difficult to render meritorious service, [people will choose] the easy way out. Western Yunnan, which constitutes half of the province, suffers from the peril of the bandits from the various ravines in Binchuan. Merchants travelling on the roads are terrified of them, and peasants in the fields resent them. Assisting the aged and leading the young, they shoulder their cauldrons and follow each other to take refuge in village markets. This happens repeatedly throughout a single year. Is it a crucial or a trivial matter?

The state has established watches and guards (jianhou zhishou 建侯置 守), constructed walled cities and set up Guards to deal with the bandits. Many native officials (qiuling 酋領) have been captured and arrested on account of them. Also, sentries on rotation (fanshu 番戌) and watches (yu 御) have been set up to guard against them, but their tasks are so demanding (ququyingying 篗篗營營) that they go without sleep and rest. Is it easy, or difficult, to render meritorious service in this situation? Tightening restrictions creates more bandits. Regret comes as soon as the method for dealing with them is formulated. What is the reason for this? It derives from a mistaken, excessive concern with profit and loss.

When the bandits first emerged, some suggested mobilising the populace, while others said, "we have no means to pay for the cost"; some suggested suppressing them, while others remarked, "who is going to bear the blame?"; some suggested going deep into their territory, while others pointed out, "instigating conflict invites disaster". Subsequently, this caused wise men to miss the [opportunity] to strategise, and caused the courageous to lose morale, and for the time being they concealed the reality when writing (miwen 彌文) in order to absolve themselves of responsibility. For this reason, bandits escape unnoticed by watches ( $y u$ 御) positioned over a hundred $l i$ away. They blame (buyu 捕於) officials in adjacent jurisdictions, but the bandits have already left by the time officials go out on patrol. If you block the east, they slip out from the west; if you focus on the front they vanish from behind. In the end, the desire to economise on funds, contrarily made it twice as expensive; the desire to save labour actually created more work; and the inclination to avoid disaster resulted in endless disasters. It is for this reason that I say, "when considering matters, excessive concern with profit and loss causes people to ignore the crucial in favour of the trivial."

Stated simply, the febrile worries of the Ming bureaucrats were not accompanied by firm plans and concerted efforts. Li Yuanyang offered two reasons for their inaction. First, as noted in the phrase "we have no means to pay for the cost", the bureaucrats claimed a lack of funds. This excuse was a weak one because the Ming invested in local defence by establishing Watches and Guards and even constructed walled cities for protection against raiders from the internal frontier. One particularly notable instance was the addition of a defensive perimeter wall 
with four gates for the Daluo Guard 大羅衛 in 1494 (Hongzhi 7) at Zhoucheng 州城 in the lowlands in today's Binchuan county. ${ }^{70}$ A stele by Xiao Jin 蕭縉 erected in 1555 (Jiajing 34) records the establishment of civil and military administration for the express purpose of putting an end to raiding: ${ }^{71}$

The inhabitants suffered grievous hardship during the exceptionally wild despoliations of 1490 (Hongzhi 3). They complained to the local authorities over and over again, but the emperor only heard their case after it was pushed up to higher levels (shanggan chenting 上干宸玨). The emperor ordered the judges in the military guards ${ }^{72}$ and various offices ( $s i$ 司 $)^{73}$ to jointly discuss the case, and they established [Binchuan] as a sub-prefecture and set up the garrison at this place. They transferred [troops from] the Lancang and Erhai Guards, divided them into left and right, ${ }^{74}$ and shifted the entire army to protect the sub-prefecture. Registered households ( $\mathrm{min}$ ) were moved from Zhaozhou, Taihe and Yunnan [counties], and divided into twelve $l i$ 里.

One $l i$ comprised 110 households. Thus, the bureaucrats moved 1,320 civilian households. The 1510 Yunnan Gazetteer records the places of origin of the transferred households as follows: 990 households from Taihe county (9 li), 110 from Zhaozhou (1 li), and 220 from Yunnan county $(2 \mathrm{li}) .^{75}$

The Veritable Records of the Xiaozong Emperor describes the trouble caused by non-registered Luoluo on 23 April 1493 (8/4/Hongzhi 6): ${ }^{76}$

Various types of Yiluo [夷羅 = barbarian Luoluo] gather around the walled city of Daluo, and bandits make lairs there. State troops are exhausted guarding against them, and civilians on corvée service are tormented while transporting goods and materials.

The ever-present threat of attacks from Luoluo resulted in the creation of Binchuan sub-prefecture in 1494. To establish law and order, bureaucrats constructed a military infrastructure by transferring troops from garrisons in neighbouring Yunnan county (Erhai Guard) and Beisheng sub-prefecture (Lancang Guard). They even populated the new sub-prefecture with registered populace from today's Dali, Fengyi and Xiangyun, organising them into lijia, an arrangement in which groups of ten households equitably shared taxes and labour services. However, walled fortifications and garrisons alone proved inadequate. Secure defences had to be accompanied by well-planned military campaigns into the internal frontier to eliminate raiding.

The second reason was fear of failure. The thought of debacles terrified the bureaucrats and deterred them from launching military campaigns. They voiced their trepidation regarding responsibility, querying, "who is going to bear the blame?" The cited statement by Xiao Jin, "the emperor only heard their case after it was pushed up to higher levels", reflects the reluctance of bureaucrats to respond to the crisis promptly. In fact, they required four years (1490 until 1494) 
to fortify Binchuan sub-prefecture. As observed in the 1573/74 campaign, mounting large-scale expeditions into the internal frontier entailed close co-ordination between civil, military and native officials and depended on wellorganised logistical support for success. Li Yuanyang singled out fear of failure as a cause of bureaucratic apathy precisely because such operations were complex, involving synchronisation between bureaucrats and native officials. By choosing the safe strategy of not doing anything that might jeopardise their careers, the bureaucrats inadvertently preserved the status quo. The cautiousness of bureaucrats impeded the eradication of raiding.

Although trenchantly critical of bureaucrats, Li Yuanyang acknowledged deserving individuals. For instance, in his Record of the Earth-walled City of Baiya, he narrated the efforts of an energetic bureaucrat named Zhang. The Ming stationed bureaucrats at Baiya dian 白崖甸, located in today's northeast Midu county, to supervise the capture of bandits and to oversee native officials (du bu dazei kongyu tuguan 督捕盜賊, 控駆土官) in 1522 (Jiajing 1). Contrary to expectations, this measure ended up aggravating the situation. Raiding escalated, and despite countless petitions to construct a wall around Baiya, no bureaucrat took up the task until the arrival of Zhang forty years later in 1564 (Jiajing 43). Zhang fortified Baiya with a wall, armed the populace, and trained 1,000 able-bodied men for defence. According to Li Yuanyang, his measures, particularly the organisation of local defence, ensured that "the bandits dared not approach within $300 l i$ of Baiya" that year. ${ }^{77}$

It was the negative attitudes of bureaucrats that perpetuated raiding. Ostensibly valid concerns, such as the need to save on expenditure, reduced morale and created a milieu in which bureaucrats "absolved themselves of responsibility" by simply doing nothing. Although not their original intention, tardiness, caution and inaction on the part of bureaucrats worked to the benefit of the upland raiders, allowing them time to escape. This situation led Li Yuanyang to conclude, "the desire to economise on funds, contrarily made it twice as expensive; the desire to save labour actually created more work; and the desire to avoid disaster resulted in endless disasters." The attitude of Ming bureaucrats themselves contributed substantially to the prolongation of raiding.

\section{Upland leaders of Lukui Mountain: $c .1671$ to $c .1724$}

The arguments presented by James Scott in his The Art of Not Being Governed are founded on the premise that upland societies in South China, Southwest China and Southeast Asia share a universal political and social culture that transcends differences in ethnicity and the size of the lowland polities that they resist. Scott assumes that this universality makes possible the writing of a comprehensive history of upland peoples. I have noted that diversity in the scale of lowland political power, not to mention the structures of upland societies themselves, render Scott's claim highly questionable. ${ }^{78}$ By studying case histories of upland-lowland relations and tabulating empirical evidence, we can identify features common to upland societies in circumscribed contexts. In addition to 
Iron Chain Gorge, other internal frontiers of varying size within Yunnan troubled the Ming state. For instance, two Pu 蒲 (Mon-Khmer speaking ethnic group) villages located only a hundred $l i$ from the walled city of Yongchang prefecture, an important administrative centre on the route to Myanmar, remained outside the orbit of Ming governance for two centuries. Although these two villages raided the lowlands, the Ming only conquered them in 1586 (Wanli 14), eleven years after the demise of Iron Chain Gorge. ${ }^{79}$

To enhance our understanding of the nature of the internal frontier in western Yunnan, I compare it with the case of Lukui Mountain 魯魁山 (hereafter Lukui), a stronghold of Yi (Luoluo) leaders located deep in the mountains near Xinping county 新平縣. The purpose of this comparison is to place the political organisation that supported the upland leaders at Iron Chain Gorge within a broader context and demonstrate the prevalence of organised raiding by upland leaders in Yunnan. ${ }^{80}$

Lukui lay in the Ailao mountain range that skirts the border of Xinping county. Situated at the margins, it constituted an internal frontier at the boundary of land directly administered by imperial bureaucrats and territory under the jurisdiction of native officials. It had been renowned as a hotbed of agitation since the early seventeenth century, if not earlier. ${ }^{81}$ The Luoluo leaders of Lukui raided lowlands under imperial administration to the north, east and west of their mountain. When imperial bureaucrats launched attacks, they slipped away south into territories under the jurisdiction of native officials, and other non-Han leaders, where imperial bureaucrats could not track them down. ${ }^{82}$ In my 2004 study, I note two factors that prevented Qing forces from apprehending the Lukui leaders. First, the Lukui leaders maintained escape routes to places of refuge. Second, because the Qing state established no permanent government offices at Lukui, the leaders returned to continue raiding after imperial troops withdrew.

Within the internal frontier of western Yunnan, the Ming only succeeded in appointing a limited number of leaders to official positions, the most notable being Luo Qinkuai, one of the Ten Kings. At Lukui, all four upland leaders held appointments as Native Officials of the Qing state. Their association with the Qing dated back to 1672, prior to Wu Sangui 吳三桂 (1612 1678) rebelling against the Qing and declaring himself Emperor of his own Zhou 周 dynasty in 1674. Raiding by these leaders continued from 1671 to 1724 , a fifty-year period spanning the transition from Wu Sangui's regime to the tightening of administrative control over non-Han societies by E'ertai 鄂爾泰 as Governor-general of Yunnan and Guizhou. The Lukui leaders appear in official sources during an era of political turmoil.

Attempting to control raiding, Wu Sangui issued military titles to the four Luoluo leaders of Lukui in 1672. After the collapse of the rebel Zhou dynasty, Qing authorities re-issued all four leaders with Native Official titles in 1682. They appointed Yang Zongzhou 楊宗周 as a Native Vice General and Pu Weishan 普 爲善, Fang Conghua 方從化 and Li Shangyi 李尚義 as Native Brigade Vice Commanders. Fan Chengxun 范承勳 (? 1714), the new Governor-general of 
Yunnan and Guizhou, ratified their positions in the hierarchy of native officials by assigning new seals and new titles sometime between 3 January and 1 February 1688 (12/Kangxi 26). Yang Zongzhou now became Native Vice Magistrate of Xinping county, and Pu Weishan, Fang Conghua and Li Shangyi became Native Police Chiefs.

The incorporation of the four leaders into the native official system did not put an end to raiding. Fang Jingming and Pu Youcai (presumably related to Fang Conghua and $\mathrm{Pu}$ Weishan) even had the audacity to besiege the walled city of Yuanjiang prefecture 元江府 and commit several murders to square a personal debt in 1723. Lukui leaders understood subordination to the Qing as a ritual gesture. Therefore, their submission to the Qing as the dominant lowland political authority did not guarantee compliance. With a very different mind-set from that of Qing bureaucrats, the leaders did not regard ritual subordination as incongruous with raiding. Even the annulment of the Native Official title of Li Shang in 1691 for expropriating commodities from the local populace failed to discourage other leaders from collecting levies from lowland villagers.

At Lukui, we observe a similarity with Iron Chain Gorge. Upland leaders sustained their livelihoods through raiding. The Lukui leaders obtained revenue from levies imposed on the populace. This practice originated in $\mathrm{Wu}$ Sangui's policy of issuing military titles in return for annual payments, known as leather helmet silver (pikui yinliang 皮盔銀兩). This arrangement resembled tax farming. Wu sanctioned the collection of silver from the local populace to pay for the helmets, allowing them to keep any silver left after payment as their own "income". Military titles undoubtedly bolstered the status and prestige of Lukui leaders, and $\mathrm{Wu}$ Sangui's authorisation facilitated their access to lowland resources.

Cai Yurong 蔡毓榮 (?-1699), the Governor-general of Yunnan and Guizhou (1682 to 1686), left a detailed description of the collection of levies by Lukui leaders during the early $1680 \mathrm{~s}:{ }^{83}$

The bandits freely go out to the four quarters and issue each village with one piece of engraved wood. They collect protection silver (baotou yin 保 頭銀), which varies in amounts from over ten taels to twenty or thirty taels and are insatiable in their demands for swine, sheep, fowls and rice wine. Any slight failure to satisfy them, leads to arbitrary plundering and murder. As a result, destitute and homeless people, along with those in the vicinity of the wild bandits, gladly join them and become robbers. For as long as eight years [upland leaders] have enlisted even larger numbers of desperadoes, and eighty to ninety per cent of the villages and estates in all the prefectures, sub-prefectures, and counties in Yunnan comply with their extortions.

The Qing regarded the Lukui leaders as intractable, rapacious strongmen. They persisted in their collection of imposts and random pillaging after the defeat of $\mathrm{Wu}$ Sangui in 1681 because they interpreted the reinstatement of their 
Native Official titles as an endorsement of past practices. They required raiding and "protection silver" to support their increasing numbers of followers, and they could not mobilise men without a source of revenue. At that time, the Qing lacked sufficient resources to take decisive action against Lukui.

Topography, intermarriage with native officials, and amnesties constituted the three main factors that enabled Lukui leaders to evade apprehension by Qing armies. Gao Qizhuo 高其倬, Governor-general of Yunnan and Guizhou, identified these factors in a secret memorial to the throne dated 11 May 1724 (19/04/ Yongzheng 2). He noted that although the Qing had encircled Ailao Mountain on three sides, the leaders easily escaped from the fourth side into territory under the jurisdiction of the native officials of Weiyuan 威遠土州, Zhenyuan 鎮沅土 府 and Cheli 車里宣慰司 (Sipsong Panna). Gao explained how the upland leaders manipulated topography, intermarriage and amnesties to remain outside the orbit of the Qing state: ${ }^{84}$

In times of peace, the bandits enter into marital relations, take out father/son relationships or swear oaths as brothers with the native officials, their children and headmen. As soon as trouble arises, government troops attack the bandits from three sides, but they escape from the direction of the native officials. The native officials either hide and conceal them or allow them to pass freely to places in the miasma-ridden lands beyond the border, where it is difficult for government troops to go to arrest them. Governors-general and Grand Coordinators being afraid of meting out punishment always delay, and [end up] offering amnesties, exempting them from penalisation as an expedient measure. This acknowledges the current situation, and as a result the fugitives take the opportunity of amnesties to return to Qing administered territory (内地) again and harm the people as before. It is precisely because no one has been willing to directly investigate the situation thoroughly in the past that we have been left with a legacy of disaster now.

Whether real or fictive, marital relationships guaranteed Lukui leaders protection from native officials in times of emergencies, either in the form of harbouring them or by facilitating their flight to refuges located further south in today's northern Myanmar and Northern Laos. Gao Qizhuo emphasised that by pardoning renegade leaders Qing bureaucrats sustained an endless cycle of escape/ return/raiding. From the viewpoint of the Qing court, it was reluctance to take decisive action that perpetuated the cycle. Qing bureaucrats resembled their sixteenth-century Ming counterparts in their negative attitudes regarding dealing with upland leaders. They all choose the easy way out.

The cases of Lukui and Iron Chain Gorge reveal features common to leaders in both internal frontiers. First, both groups of leaders possessed inaccessible strongholds and the capability to organise large-scale raiding over broad tracts of the lowlands. Topography made Iron Chain Gorge so impenetrable that it functioned both as a place of refuge and an internal frontier for nearly 200 years. In the case of Lukui, Qing forces did penetrate this internal frontier but only 
temporarily, failing to conquer it for fifty years because of the existence of escape routes leading to refuges in marginal areas of Southeast Asia lying outside imperial jurisdiction. The imperial state only managed to establish control over internal frontiers when strong-willed bureaucrats, such as Zou Yinglong and E'Ertai, who possessed the energy to co-ordinate large-scale military action, appeared on the scene.

Scott emphasises inaccessibility and state evasion as universal features of upland societies. The data concerning the organisation of raiding at Iron Chain Gorge and Lukui expose the dependence of uplands on lowlands for survival, despite inaccessibility. Leaders at Iron Chain Gorge and Lukui commanded large numbers of armed men, raided lowlands systematically, and persistently demanded payments in grain and silver from villagers for "protection". Lukui leaders facilitated the collection of levies by issuing "each village with one piece of engraved wood". Scott's agenda downplays the dependence of upland on lowland.

Contrary to Scott's depiction of upland peoples as evasive and passive, Iron Chain Gorge and Lukui leaders exuded dynamism and manifested an ability to organise their populaces to collect revenue from lowland areas as a survival strategy. The Ten King Alliance revealed the existence of a regime replete with ministers and generals at Iron Chain Gorge, one that even mimicked Chinese dynastic practice by issuing seals and tallies. Kataoka Tatsuki has empirically demonstrated through a case study on a Lahu regime in present-day Menglian 孟連 (Tai: Mäng ${ }^{2}$ Lëm) in Yunnan that upland peoples did create their own polities after the eighteenth century. ${ }^{85}$ Further evidence from Northern Laos and Dehong in Yunnan has revealed that upland ethnic groups participated in the foundation and administration of lowland Tai polities. ${ }^{86}$ The data presented in this study reveal a situation opposite to Scott's scenario of lowland regimes raiding upland societies for slaves and other resources. In western Yunnan, it was the upland leaders who plundered the lowlands. The case of Iron Chain Gorge represents an attempt (despite its futility) by upland leaders to resist control by imperial bureaucrats and native officials alike. As in the instance of Kataoka's Lahu, concepts of kingship among the upland leaders of Iron Chain Gorge arose in the context of outside pressure from changed politico-economic conditions in sixteenth-century Yunnan.

\section{Conclusion}

Order was brought to Yunnan through the agency of Ming rule after 1382. However, this order was an agency dispersed among the worlds of Ming bureaucrats, native officials and upland leaders of the internal frontier in a way that defies simple labelling. The Ming's inability to independently govern the province forced it to co-administrate with ethnic leaders. It is possible to think of co-administration not simply as a product of a hodgepodge of regular bureaucrats and hereditary native officials but as the Ming state's recognition of the limited reach of its governance. This administrative infrastructure prolonged the 
existence of the internal frontier of Iron Chain Gorge and helped upland leaders retain their autonomy from the Ming for the first 200 years of the dynasty. The retention of autonomy by Iron Chain Gorge for 200 years indicates that the extent of Ming control in western Yunnan was not simply a function of Ming colonial policies, but also varied depending on the structure of internal frontiers.

The survival of internal frontiers negates the idea of an undifferentiated mass of upland peoples bent on evading the state. Their existence also defies blanket categorisation of upland societies as void of political control. Upland communities at Iron Chain Gorge and Lukui possessed a degree of political organisation. Their leaders organised them to actively engage with lowland communities to procure vital resources. This engagement involved violence, particularly at times when Ming and Qing bureaucrats restricted upland people's access to lowland resources. Upland leaders resorted to raiding to support their communities. However, in doing so, they expressed no aspirations to overthrow the Ming state and establish a new dynasty. They merely sought to maintain the livelihoods of their communities without becoming subordinate to outside political power. The embracement of concepts of kingship arose as a response by the leaders to mounting threats to their lifestyles. By creating their own regime, upland leaders sought to protect themselves from encroachments by the Ming. It was not until the raiding intensified and upland leaders of Iron Chain Gorge proclaimed themselves kings that the Ming finally took decisive action. The numerous rebellions that broke out in Southwest China during the latter half of the sixteenth century altered the bureaucratic milieu that had nurtured negative attitudes towards military action against the internal frontier. By this time, the Ming no longer tolerated widespread raiding that disrupted lowland societies. Therefore, it launched a military campaign to extend regular administration to the internal frontier.

It should be clear from this study that internal frontiers matter profoundly to the history of western Yunnan. First, the internal frontier of Iron Chain Gorge restricted the reach of social reconstruction promoted by the new Confucian elite. This study confirms similarities in Ming governance in western Yunnan with coeval internal frontiers in Guangdong, Guizhou and Hunan. After 1382, the Ming gained direct control of lowland power bases of the Mongol-Yuan and the Duan Family General Administrator and transformed the members of lowland communities into registered populaces $(\mathrm{min})$. However, the dynasty failed to extend household registration and the lijia system to the jurisdictions of native officials and upland communities within the internal frontier. With direct administration confined largely to lowland registered populace for the first 200 years, the pattern of social reconstruction by the new Confucian elite of western Yunnan resembled that in the Pearl River Delta during the fifteenth and sixteenth centuries.

Second, the case of Iron Chain Gorge illustrates the impenetrability of internal frontiers and at the same time exposes the drawbacks of attempting to govern them through the agency of native officials. The ethnoscape of western Yunnan compelled the Ming to appoint native officials to govern local populations unsuitable for direct administration by regular bureaucrats. However, the societies within the internal frontier remained so far removed from dynastic 
norms and practices that the Ming had difficulty even contacting their leaders. Invoking the age-old principle of "using barbarians to control barbarians", Ming bureaucrats charged the Gao Native Official of Yao'an prefecture with the task of managing the margins of the internal frontier adjoining Iron Chain Gorge from the late fifteenth/early sixteenth century onwards. Because the upland communities did not recognise the Gao Native Official as their overlord, this arrangement miscarried. Gao family members appointed to manage the internal frontier ended up embroiling the leaders in the power struggles of other native officials between 1567 and 1569. This outcome testifies to the dangers inherent in governing internal frontiers through native officials: kinsmen of native officials could manipulate upland leaders for their own personal gain, causing widespread unrest in the process.

Third, the 1573/74 campaign against Iron Chain Gorge exposed how heavily the Ming relied on native officials. The large number of native official troops that fought at the front line in the campaign underscores the extent of the reliance. Native officials gathered soldiers from among their own populaces, and their armies constituted the main body of the mobilised Ming forces. The Mongol-Yuan utilised the power and prestige of the deposed Duan royal family of the Dali kingdom to administer ethnic societies in western Yunnan. Their appointment as the Duan Family General Administrator transformed them into the most powerful native official in western Yunnan. ${ }^{87}$ The First Ming Emperor Zhu Yuanzhang abolished this office, choosing not to administer ethnic peoples via the mediation of the Duan. Although he placed most lowlands around Dali under the jurisdiction of regular bureaucrats, the ethnoscape forced him to appoint ethnic leaders as native officials to administrate both uplands and lowlands in certain locations. The $\mathrm{Mu}$ 木 family of Lijiang and the Zuo 左 family of Menghua represent well-known examples. Native officials constituted the mainstay of Ming rule in western Yunnan.

Fourth, the persistence of internal frontiers shaped the history of Han settlement. Internal frontiers functioned as barriers to Han in-migration. The garrisoning of Han military personnel and their families in the lowlands of western Yunnan reflects the limited reach of Ming control during the fifteenth and sixteenth centuries. The Ming established garrisons at strategic locations, occasionally even within native official jurisdictions. However, it could not position itself within the internal frontier. The permanent settlement of Han military personnel undoubtedly lubricated the transition from the Mongol-Yuan period to the early Ming by exerting a stabilising effect on lowland communities. However, as noted by Lian Ruizhi, troops from the Guards and native police chiefs proved ineffective at safeguarding vital points along communication routes and failed to eradicate raiding during the late fourteenth and fifteenth centuries ${ }^{88}$ Large-scale Han migration to the uplands of Yunnan only became possible after the state gained administrative jurisdiction over internal frontiers. Historians have emphasised the role played by American crops, such as maize and the sweet potato, in "opening up" the uplands of Southwest China for cultivation and settlement by the Han after the sixteenth century, and they cite 
the cultivation of these crops as a factor enabling Han in-migration. ${ }^{89}$ This study highlights that Han in-migration to the uplands could only occur after the elimination of internal frontiers. As basin populations in Yunnan reached saturation levels due to large-scale migration resulting from the eighteenth-century population explosion, sizeable numbers of Han settlers out-migrated from the basins to uplands under the jurisdiction of native officials on the Yunnan frontier, and some eventually passed over into Upper Burma and Northern Laos. ${ }^{90}$ Such migration only became possible after the state gained the power to govern internal frontiers and uplands, either directly through imperial bureaucrats or indirectly through native officials. The conquest of Iron Chain Gorge in 1574 marked the beginning of this process in western Yunnan.

\section{Notes}

1 This research was supported by the Hong Kong Research Grants Council (RGC) General Research Fund Project (No. 16642516).

2 James Scott (2009). Recent studies that position Yunnan in Zomia include Megan Bryson (2017), p. 12, and Kataoka Tatsuki (2013), p. 1.

3 Iron Chain Gorge (Tiesuoqing 鐵索箐, also written as 鐵鎖箐) is today’s Tiesuo Township 鐵索鄉 on the east bank of the Yupao jiang 漁泡江in the western part of today's Dayao county. Another stronghold, known as Red Rock Cliff (Chishiya 赤石 崖), lay in today's Pingchuan xiang 平川鄉, situated on the west bank of this river in today's Binchuan county. Zhang Tingyu, Mingshi, p. 8092, records: "during the Hongzhi period some [upland communities] slightly obeyed orders, and they were respectively subordinate to Yao'an 姚安 and Yaozhou 姚州. During the Jiajing period they became solely subordinate to Yao'an”. For the sake of simplicity, I use the term Iron Chain Gorge to collectively refer to all the upland communities because historical sources refer to this place as the major centre of their resistance against the Ming.

4 Regarding the Duan Family General Administrator, see Christian Daniels (2018), pp. 69-111.

5 Historians have found little evidence for widespread social reconstruction in native official jurisdictions. For instance, although communities around the prefectural city in Menghua adopted certain Confucian norms and customs by the late fifteenth century after the establishment of a Confucian school by the Native Official, this development did not result in large-scale reconstruction, as posited by Jianxiong Ma. Regarding the case of Menghua, see Tang Li (2015), p. 7. Additionally, see Tang Li (2016), pp. 48-49.

6 See Ma Jianxiong (2014), pp. 131-155, and Ma Jianxiong (2017), pp. 229-262.

7 It seems that certain native officials in the Dali basin did register the population within their jurisdictions. After being appointed Native Magistrate of Dengchuan Zhou 鄧川 州土官知州 (in today's Eryuan county) in c.1383 for meritorious service, A Zhe 阿這, a Tai aristocrat, "founded the sub-prefecture seat, registered the households (bian hukou 編戶口), constructed a school ..."; see the tomb inscription Dengchuan Zhou Tuguan Zhizhou A Shi Wushi Mubiao 鄧川州土官知州阿氏五世墓表 of 1508 (Zhengde 3) written by Yang Nanjin 楊南金, a native of Dengchuan Zhou, in Yang Shiyu and Zhang Shufang (1993), Vol. 10, p. 71. For a fuller account of the registration of upland people by the A Native Official, see Jianxiong Ma's chapter in this volume.

8 Zhang Tingyu, Mingshi, p. 8092. Additionally, see Ma Jianxiong (2014), pp. 141-145 for an account of these raiding activities.

9 David Faure (2006), p. 171, pp. 185-186. 
10 For instance, Donald Sutton studies the changes wrought on Miao society in western Hunan by the appointment of native officials within the internal frontier and in-migration by Han, paying particular attention to the settlement of disputes between Miao and Han; see Sutton (2003), pp. 41 80.

11 Lian Ruizhi (2015), pp. 46-51.

12 A woodblock reprint of the collected works of Li Yuanyang was published in the Yunnan Congshu 雲南叢書 in 1914 under the title Li Zhongxi Quanji 李中谿全集. The text was based on a manuscript copy of the edition printed by Liu Wei 劉維 and $\mathrm{Hu} \mathrm{Xi}$ 胡僖 in 1580 (Wanli 8); see the preface by Zhao Fan 趙藩 in Yunnan Sheng Wenshi Yanjiuguan (2009), Vol. 21, p. 11063. Liu Wei served as Regional Inspector (Xun'an yushi 巡按御 史), and $\mathrm{Hu} \mathrm{Xi}$ was in charge of the Military Defence Circuit of the Jinsha and Lancang Rivers (金滄道兵備道). Thus, Li Yuanyang's views carry official imprimatur.

$13 \mathrm{Li}$ Yuanyang was not the only local scholar-official determined to reconstruct local society to suit the changed circumstances of the sixteenth century. Yang Shiyun 楊士 雲 (1477-1554) also promoted reforms of marriage, burial and ritual practices to align local customs with the Ming norm; see Lian Ruizhi (2018), pp. 39-70.

14 Zhu Guozhen, Yongchuang Xiaopin, p. 679.

15 According to Hou Chong (2002), pp. 68-81, a member of the Xizhou Yang family wrote the Bai Gu Tongji 白古通記 in the late thirteenth or early fourteenth century.

16 The accounts appear in the two gazetteers edited by Li Yuanyang: the Jiajing-era (1522-1566) Dali Fuzhi and the Wanli-era (1573-1620) Yunnan Tongzhi; see Megan Bryson (2017), pp. 116-117.

17 Megan Bryson (2017), pp. 107-135.

18 Lian Ruizhi (2018), pp. 39-70.

19 See Qu Jiusi, Wanli Wugong Lu for the text. The account of the conquest of Iron Chain Gorge recorded in Mao Qiling, Mansi Hezhi is based on the text of Biographies in the Wanli Wugong Lu.

20 Qu Jiusi, Wanli Wugong Lu, pp. 569a-569b. Zhang Tingyu, Mingshi, p. 8092 writes disapprovingly that Luo $\mathrm{Si}$ "possessed magical abilities, made false seals and proclaimed rebellion".

21 E. R. Leach (1954) and James Scott (2009).

22 Ma Jianxiong (2017), pp. 256-257.

23 The written version appears in Chen Shou, Sanguo Zhi, pp. 919-921, and Luo Guanzhong, Sanguo Yanyi, p. 1175.

24 Li Ling 李零, Translator and Annotater, Sunzi Bingfa Yizhu, p. 13. The original in the Mougong pian 謀攻篇 reads: “是故百戰百勝, 非善之善者也; 不戰而屈人之兵, 善之善者也.”

25 This passage is cited in Chen Shou, Sanguo Zhi, p. 921, and Huang Shi, Ed., Huangshi Yishu Kao, Vol. 1210, p. 313. The original text reads: “亮曰: 「若留外人, 則當留 兵, 兵留則無可食, 一不易也。加夷新茂破, 父兄死喪, 留外人而無兵者, 必 成禍患, 二不易也。又吏累有廢殺之罪, 自嫌覺重, 若留外人, 終不相信, 三 不易也. 今吾欲使不留兵, 不運糧, 而綱紀粗定, 夷漢粗安故耳。」”. The text of the Han-Jin Chunqiu only survives in fragments. It records the history of the Later Han period to the reign of Emperor Min 晉壂帝 (reigned 313-316) of the Western Jin from the standpoint of Shu-Han as the righteous successor to the Han and regards the Cao-Wei dynasty (220-265) rulers as usurpers of the Han throne.

26 The two men from Zhaozhou 趙州 near Dali appointed Police Chiefs in 1383 were Li Yi 李義, who served as the Nidian Xunjian 你甸巡檢, and Li Nalin 李納麟, who served as the Annanpo Xunjian 安南坡土巡檢. Their descendants were later classified as native police chiefs (Tu Xunjian 土巡檢); see Tuguan Dibu, Shang 上, pp. 17a-18b.

27 In an entry for 12 October 1499 (Yichou 9/Hongzhi 12) the Xiaozong Shilu, p. 2737, records:

there are six, or seven bandit lairs in the areas of Yao'an prefecture, Daluo Guard and Binchuan, and military personnel and civilians have suffered immense 
damage. We request to establish a Military Defence Vice Commissioner (Bingbei Fushi 兵備副使) at the walled city of Lancang 瀾滄城, and place the prefectures, sub-prefectures and Guards of Yao'an, Daluo, Binchuan, Daluo Heli, Lijiang, Dali, Erhai and Jingdong under its control.

又姚安府, 大羅衛, 賓川州地方有賊穴六七處, 軍民受害甚切。請添設兵備 副使於瀾滄城, 以又姚安, 大羅, 賓川, 鶴麗, 麗江, 大理, 洱海, 景東府 州衛所屬之。

Regarding the foundation of Binchuan sub-prefecture, see Peng Gang and Zhou Jifeng, Zhengde Yunnan Zhi, p. 161.

28 Lian Ruizhi (2015), pp. 39-40.

29 Biographies records the administration of the marginal area at Juque 直卻 and the disturbances there; see Qu Jiusi, Wanli Wugong Lu, p. 568a.

30 Gao Feng assumed the office of Native Prefect in 1496 (Hongzhi 9) and died in 1530 (Jiajing 9); see Tuguan Dibu, shang, 59a.

31 Gao Chun served as Native Vice Magistrate of Yaozhou from 1506 (Zhengde 1) to 1530 (Jiajing 9); see Tuguan Dibu, shang, 59b-60a.

32 Gao Bi succeeded to the office of Native Vice Magistrate of Yaozhou in 1537 (Jiajing 16); see Tuguan Dibu, shang, 60a.

33 Gao Qidou assumed the office of Native Prefect of Yao'an in 1530 (Jiajing 9) after the death of Gao Feng; see Tuguan Dibu, shang, 59b.

34 Zhang Tingyu, Mingshi, p. 8096. Mao Qiling, Mansi Hezhi, juan 10, 3b-4a, p. 417, also provides an account of the collusion between Gao family members and Feng Jizu and their incitement of the Iron Chain Gorge leaders to raid Menghua.

35 Qu Jiusi, Wanli Wugong Lu, p. 568a.

36 Lian Ruizhi (2015), p. 42.

37 Gao Xi dispatched 800 men from the jurisdictions of the six ethnic headmen (huotou 火頭) of Tanglang 螳螂 (Table 5.1, no. 3) and 600 men from the five ethnic headmen at Gudi 古底 (Table 5.1, no. 4), who were all under his jurisdiction; see Qu Jiusi, Wanli Wugong Lu, p. 576a.

38 Erhai Bingbei Dao Tiesuojing Junying Biji 洱海兵備道鐵索箐軍營廳壁記; see $L i$ Zhongxi Quanji, 7: 21a, in Yunnan Sheng Wenshi Yanjiuguan, Yunnan Congshu, Vol. 21, p. 11262. The original reads: “其蠻夷種族不一，統名之曰“㭗”。學性 獷悍, 業習強驽, 以毒塗矢鏃, 中人立死, 莫敢掑其鋒。部落七十餘, 而鐵索 箐, 赤石崖其魁也。地屬賓川州, 而蒙化, 姚安, 楚雄諸郡咸被其害, ...。”

39 Qu Jiusi, Wanli Wugong Lu, pp. 568a-568b. Ma Jianxiong (2014), pp. 142-145, and Lian Ruizhi (2015), pp. 21-22, also mention the Lisuo 力些 (Lisu 傈傈 in today's PRC classification) and the Mosuo 麼些 (Mosuo 摩梭 in today's PRC classification). However, Biographies, the most detailed contemporary report available, does not record these terms.

40 Erhai Bingbei Dao Tiesuojing Junying Biji; see Li Zhongxi Quanji, 7: 21a, in Yunnan Sheng Wenshi Yanjiuguan, Yunnan Congshu, Vol. 21, p. 11262, and Qu Jiusi, Wanli Wugong Lu, p. 568b. According to the Qianlong era scholar-official Zhang Licheng 張履程 (Ming Qianning Wang Mu Ying Shi Shixi Lue 明黔寧王沐英氏世襲畧), Mu Changzuo 沐昌祚 and Zou Yinglong 鄒應龍 pacified seventy-two villages of the Lisuo at Iron Chain Gorge; see Wang Song, Ed., Yunnan Beizhengzhi, in Yunnan Sheng Wenshi Yanjiuguan, Yunnan Congshu, Vol. 13, 21:66a, p. 6837.

41 The figure of twenty-four leaders is approximately corroborated by Li Yuanyang in Shoubei Chenjun shanzhi xu 守備陳君善職序 (undated), in which he mentions "twenty-odd barbarian bandit villages" around Iron Chain Gorge and Red Rock Cliff; see Li Zhongxi Quanji, 6:4b in Yunnan Sheng Wenshi Yanjiuguan, Yunnan Congshu, Vol. 21, p. 11227. 
42 Xianzong Shilu, juan 191:4b-5a, p. 3400. The original reads: “癸卯，雲南總兵官黔 國公沐琮等奏鐵索箐蠻贼王通海等舷聚劫掠, 臣等將兵討之, 分道而迫連戰累 捷，生擒三百九，斬首一百三十九，俘獲一百三十三。其投崖及餓允者甚临， 獲畜產兵仗無算, 湊之上賜初獎屬之。”

43 Qu Jiusi, Wanli Wugong Lu, pp. 572a, 577b. The account of the campaign provided below is also based on Biographies; see Wanli Wugong Lu, pp. 569b-578b.

44 Qu Jiusi, Wanli Wugong Lu, pp. 573b-574a. Regarding temples for making sacrifices to the god of the commander's banner in Yunnan during the Ming, see Tang Li (2016), pp. 31-58.

45 Qu Jiusi, Wanli Wugong Lu, p. 572 b.

46 Biographies does not record the number of regular Ming army troops serving under Mu Changzuo 沐昌祚, the Zhengnan Jiangjun 征南將軍, positioned at Weichu 威楚 (today's Chuxiong) to prevent flight to the east, those serving under Tang Yang 湯仰 at Dayao blocking the southern escape route, and Tian Rubi 田汝㢱 guarded the western escape route; see Qu Jiusi, Wanli Wugong Lu, pp. 572b-573a.

47 Only 30 per cent of the 240,000 troops were Ming regulars. The forces were commanded by Li Hualong 李化龍 (1554-1612), Governor of Sichuan, and Guo Zizhang 郭子章, Guizhou Provincial Governor; see John Herman (2007), pp. 162-168.

48 Now within the jurisdiction of Yongren county 永仁縣.

49 Yao'an Zhidao Gongguan Biji 姚安職盗公館壁記 (undated); see Li Zhongxi Quanji, 7:24b-25a, in Yunnan Sheng Wenshi Yanjiuguan, Yunnan Congshu, Vol. 21, pp. 11263-11264. The relevant passage reads:

They cleared the site for the foundations on the mountain 通山辟址, hauled stones and cut timber for constructing halls (tang 堂), bedrooms ( $q$ in 寝), corridors (lang 廊), and quarters (she 舍). They raised the gates high and made the doors magnificent in order to overawe traitors, and to provide the honest and good with something reliable. It was intended that they must choose a site close to the Fengshan Buddhist temple, and that it must be encircled with a wall like a small city ...

於是, 公與分巡衡陽易公協心經始, 通山辟址, 輦石伐木, 為堂, 為寝, 為 廊, 為舍, 高其閈閞, 壯其門閭, 以威反側, 以怙善良。然選地必以鳳山佛 寺為依, 而繚垣必如小城者, 楊侯盖有微意焉。

50 Yao'an Zhidao Gongguan Biji 姚安職盜公館壁記 (undated); see Li Zhongxi Quanji, 7:23b-24a, in Yunnan Sheng Wenshi Yanjiuguan, Yunnan Congshu, Vol. 21, p. 11263.

51 Jian Yangbi Shoubei Shu Ji 建漾濞守備署記 (undated); see Li Zhongxi Quanji, 7:26a in Yunnan Sheng Wenshi Yanjiuguan, Yunnan Congshu, Vol. 21, p. 11264. The original reads:

稽金蒼守備自嘉靖間建設以來，前后才三人。初吳侯子忠，次元侯位，相繼 升都司。今為李侯, 前此駐無定所, 往來三郡之間, 馬不停蹄, 坐不溫席, 事若甚勤而風掃電掣。其於伏匿隱奸不能悉察, 何也。無整㗇之素也。治旅 無地, 故眾不整; 馬上應酬, 故事不㗇。今夫榷檢郵滯, 稗官也。必為廨以 錀之, 然後啓閉留縱司焉。守備金緋重職, 提千里之兵以守扼塞, 遠控徼 夷, 近壓奸宄, 其為任不輕也明矣。而廨宇弗置, 萍寄無方, 豈所以坐策折 衝而觀示千里也哉。不整不暇, 職此之由矣。

52 Erhai Bingbei Dao Tiesuojing Junying Biji; see Li Zhongxi Quanji, 7:21a, in Yunnan Sheng Wenshi Yanjiuguan, Yunnan Congshu, Vol. 21, p. 11262.

53 Binchuan Pingdao Ji 賓川平盜記, in Yang Shiyu and Zhang Shufang (1993), Vol. 10, p. 91.

54 Shoubei Chenjun shanzhi xu (undated); see Li Zhongxi Quanji, 6:4b, in Yunnan Sheng Wenshi Yanjiuguan, Yunnan Congshu, Vol. 21, p. 11227. The original reads: “姚安之鐵索箐, 賓川之赤石崖, 其間夷賊部落二十餘處, 長槍勁驽, 流却村屯。 二百年來，為盜益熾，殺人孔道之上，不避権施。虜士庶之家，迫臨城郭，蔓 延四出, 莫之敢攖。” 
55 Erhai Bingbei Dao Tiesuojing Junying Biji; see Li Zhongxi Quanji, 7:21a-21b, in Yunnan Sheng Wenshi Yanjiuguan, Yunnan Congshu, Vol. 21, p. 11262. The original reads:

地屬賓川州, 而蒙化, 姚安, 楚雄諸郡咸被其害, 始而劫掠商賈, 中而焚虜 村屯, 既而族黨日眾。所過殺人無厭, 孔道之上横行自恣。軺幰經由, 非哨 望擁護則不可行郡縣。自城郭之外, 凡有室盧田土者, 自一尺以上皆輸穀 麥, 以正寬免。家蓄器物, 衣占, 布帛, 雞豚, 恣其櫻取, 不敢少撓。苟違 其意, 大禍立至。二百年來, 百爾運籌, 為之調軍監衛不已, 又為之增糧置 禦不已, 又為之募土兵, 倩酋長。公帑日見其損, 寇偷日見其益。諺云：“ 苟非其人, 貓鼠相狎”。此之謂也。

56 Difficulty guaranteeing the safety of merchants was not limited to the areas afflicted by raiders from the Iron Chain Gorge. It was also common in other parts of western Yunnan. He Mengchun 何孟春 reported in a memorial to the throne that on the border between Jianchuan and Heqing sub-prefectures bureaucrats had "to hire Luoluo from the frontier-barrier at Xuanhua 宣化關 in Dali prefecture to serve as shouba 守把 to safeguard upland thoroughfares in the area and make them passable for merchants" 顧 募本府宣化關羅羅守把, 保障一帶山路, 商賈始通. He concluded that Police Offices (Xunjian si 巡檢司), originally established to apprehend bandits at frontierbarriers, could no longer be relied on because they have "become nominal 而巡司竟 為虛設”; see He Mengchun, He Wenjian Shuyi, 7:3b. Lian Ruizhi argues that the inability of native police chiefs to maintain the safety of upland thoroughfares arose in response to the introduction of the tax reform known as the combined land and poll tax (diding yin 地丁銀) during the Wanli period, which encompassed a shift from collecting labour in kind towards taxes linked to land. This measure is commonly known as the Single Whip reform). According to Lian, native police chiefs could no longer muster men to serve as bowmen (gongbing 弓兵) because the men paid their labour tax with money rather than serving in person; see Lian Ruizhi (2015), p. 30.

57 Lian Ruizhi (2015), pp. 39-40.

58 Tiesuo Chuan Pingzei Ji 鐵索川平賊記, Li Zhongxi Quanji, 7:22b-23a, in Yunnan Sheng Wenshi Yanjiuguan, Yunnan Congshu, Vol. 21, p. 11262-11263. The original reads:

楚雄郡東北界，其田膴美，其人善良，其有廣室以居，鮮服以遊，然皆倣陃 窮歳不能安其生者。以地鄰鐵索川, 寇盜出沒, 摽掠傷害, 無有甯歲。居人 奔走避匿, 家蓄藏積, 委而去之, 既而復業, 生計已空。但得不毀室盧斯幸 矣。蓋自有郡以來, 歲歲恒然也。當路憫民疾苦, 未嘗不以為憂。然賊地廣 臨三郡之界, 縱橫二州四縣之間, 亂山如沸, 遂箐如井, 林樾參天, 荆榛塞 路, 截嵲險阻, 勢難馳駎。

Ming officials launched two campaigns against the bandits, one in the last year of the Longqing period (1572) and one more in 1573 (Wanli 1).

59 These were the three prefectures of Dali, Chuxiong and Yao'an 姚安軍民府, the two sub-prefectures of Yaozhou 姚州 and Binchuan 賓川州, and the four counties of Yunnan 雲南縣, Dayao 大姚縣, Wuding 武定縣 and Yuanmou 元謀縣.

60 Yaoan Zhidao Gongguan Biji 姚安職盜公館壁記 (undated); see Li Zhongxi Quanji, 7:23b, in Yunnan Sheng Wenshi Yanjiuguan, Yunnan Congshu, Vol. 21, p. 11263. The original reads: “然而兩省接壤之處, 列郡交界之區, 政令之所不及, 軺㯖之 所不經。阻險負固, 協眾聚黨, 必有兇萑巨盜潛伏乎其間。”

61 He Mengchun, He Wenjian Shuyi, 7:7a. The original reads: “各巢素皆結親黨, 出 則彼此相應, 其鋒莫敵。入則散居巢穴, 其蹤難追。”

62 Lian Ruizhi (2015), pp. 23-27.

63 Li Yuanyang, Wanli Yunnan Tongzhi, juan 3:45b, p. 324. The original reads: “近郡 之夷, 名儸儸, 棵夷, 散摩都, 強悍好鬥。交易用鹽米, 一日一小市, 五日一大市”。 
64 Li Yuanyang, Wanli Yunnan Tongzhi, juan 3:44b. The original reads: “寶關山: 在司 治西一里, 勢高百伋, 以其通鹽路之要路, 土人名曰寶關, 蓋以鹽為寶也。”

65 See Bingbei dao Jianggong qusibei 兵備道姜公去思碑 in Yun Long, Ed., Minguo Yao'an Xianzhi, p. 1898. The original reads: “前此我輩下山即執, 誣指為賊, 閉 箐深居, 又難以得食, 求活之道, 非却無由也。生未嘗見官泣此地, 亦不曾聞 此言，有苦莫伸。”

66 See Bingbei dao Jianggong qusibei in Yun Long, Ed., Minguo Yao'an Xianzhi, p. 1898. The original reads: “自是, 群蠻出箐為市, 無異編民。行商宵征, 哨堡晏寢, 百年來末之前見也。”

67 Binchuan Pingdao Ji 賓川平盜記 in Yang Shiyu and Zhang Shufang (1993), Vol. 10 , p. 91. The original reads: “藉其人以為我兵, 教其幼有同己子。外以糧餉答其 功, 內以拘致訪其邪計。為之立市, 以通有為。許以行為鹽, 任其負載。自新 更始，則立罷追之條；足食足兵，再下社倉之令。”

68 Lian Ruizhi (2015), pp. 43-44.

69 Binchuan Pingdao Ji 賓川平盜記 in Yang Shiyu and Zhang Shufang (1993), Vol. 10, p. 91. The original reads:

事有大而眩於利害者, 以小忽之: 功有難而明於緩急者, 以易成之。賓川諸 箐之盜, 滇西半省被其患。商旅恐於途農民怨於野, 扶老攜幼, 負釜而避 匿者相屬於村墟。一歲之中, 蓋一再焉。茲其事大乎, 小乎? 國家為之建侯 置守, 築城設衛, 又為之酋領擒捕不已, 又為之番戌立御, 篗䨉營營, 不遑 寝息。茲其功難乎, 易乎? 然而, 禁越密而盜越滋。法方立而悔已至。此其 何故哉? 眩於利害之過也。方盜之起也。有言動眾，則曰：“費無從出。” 有言誅剿, 則曰：“处將誰任?”有言深入，則曰：“倁覺速禍。”遂使 智者失謀, 勇者喪氣, 姑為彌文以自塞責。是故, 戍御於百里之外, 盜逸而 御不知：責捕於鄰境之官，官旋而盜已出。塞東漏西，顧前失後。卒之， 欲省費而費反倍, 欲省力而力愈勞, 欲免禍而禍不已。故曰“眩於利害, 忽大為小”也。

70 Xiaozong Shilu, p. 2737, records that approval for the establishment of Binchuan subprefecture 賓川州 and the Daluo Guard 大羅衛 was issued on 23 April 1493 (8/4/ Hongzhi 6).

71 The stele is A Record of the Renovation of the Daluo Garrison (Congxiu Daluo Wei $J i$ 重修大羅衛記) in Yang Shiyu and Zhang Shufang (1993), Vol. 10, p. 93. The original reads: “弘治庚戌, 大肆猖獗, 居民甚苦之, 屢有辭於當路, 繼而上干宸聽。乃 命撫鎮諸司薟議之, 於地建州設衛, 調瀾滄洱海衛所, 分布左右, 全師徙守州。割 趙州, 太和, 雲南附近之民, 分里一十有二。” The 1510 Yunnan Gazetteer also records the construction of this city; see Peng Gang and Zhou Jifeng (1990), p. 177.

72 Fuzhen 撫鎮 in the original. However, this term is a mistake for zhenfu 鎮撫.

73 Here, "office" refers to the Provincial Administration Commissioner (Buzheng shi 布 政使) and the Surveillance Commissioner (Ancha shi 按察使).

74 Xiaozong Shilu, p. 1385, in an entry dated 23 April 1493 (8/4/Hongzhi 6), records the addition of "one garrison and left and right battalions 左右千戶所".

75 See Peng Gang and Zhou Jifeng (1990), p. 161.

76 Xiaozong Shilu, p. 1385. The original reads: “大羅城諸種夷羅所聚, 盜賊所穴, 官軍 疲於戍守, 民夫困於轉輸。”

77 Baiya Tucheng $J i$ 白崖土城記 (undated); see Li Zhongxi Quanji, 7:52a-53a in Yunnan Sheng Wenshi Yanjiuguan, Yunnan Congshu, Vol. 21, pp. 11277-11278.

78 Christian Daniels (2013), "Introduction", pp. 7-8.

79 The subjugation of these two villages is recorded in an addendum to a stele of 1587 known as the Xuzhong Ciji (恤忠祠記 The Epitaph on the Shrine for the Repose of the Souls of the Loyal) authored by Li Shida 李士達, an Assistant Surveillance Commissioner for the Jinsha and Lancang (Mekong) Rivers 按察司分巡金滄簽事; see text in Tang Li (2011), p. 249, and in Baoshan Shi Wenhua Guangdian Xinwen Chubanju (2008), pp. 134-137. 
80 The account of Lukui Mountain is based on Christian Daniels (2004) pp. 694-728, in Japanese. For an English translation, see Christian Daniels (2019), pp. 188-217.

81 In the memorial to the throne known as Xinping Jiaozei Baojie Shu 新平剿賊報捷, dated the tenth day of the tenth lunar month of Tianqi 4 (1624), Min Hongxue 閔洪學, Grand Coordinator of Yunnan (Xunfu 巡撫) reported the pacification by the Ming army of the Lukui bandits, who resisted for approximately an entire year between late 1623 and 1624. The disturbances started with a raid by approximately 600 men from Xinping county on the area around the Baoxiu market 寶秀街 in Shiping sub-prefecture 石屏州 on 27 November 1623 (6/10 intercalary month/Tianqi 3); see Min Hongxue, Fu Dian Zoucao, 5:60b-62a. Xiaozong Shilu, pp. 2492-2496, contains a digest of this memorial.

82 Cai Yurong 蔡毓榮 (?-1699), a Han white banner man 漢軍正白旗人 who served as Governor-general of Yunnan and Guizhou from 1682 to 1686, described how the upland leaders (he refers to them as bandits) used their strategic position at Lukui Mountain to sally forth to raid and then escape when pursued by Qing troops:

Lukui is located in the middle of the myriad mountains, and overlaps with the borders of Xinping County, Xi'e County, Menghua, Yuanjiang, Jingdong and Chuxiong [prefectures]. It stretches far and wide, and has deep forests and thick ravines. The bandits can enter the areas of Xinping, Xinhua, Yuanjiang, Yimen, Ejia, Nan'an and Jingdong, all of which lie on its inside, and escape out into the areas of Sipsong Panna (Cheli), Pu'er, Cengtung [Kengtung], Zhenyuan, Mäng Mën (Meng Mian 猛緬: Lincang county 臨滄縣), and Vietnam (Jiaozhi 交阯) which lie on its outside. For this reason, it is very difficult to guard against them, and also not easy to suppress them.

魯魁在萬山之中, 跨連新嶍蒙元景楚之界, 綿瓦廣遠, 林深箐密, 其內則新 平, 新化, 元江, 易門, 石十咢嘉, 南安, 景東一帶地方, 賊皆可入, 其外 則車里, 普洱, 孟艮, 鎮沅, 猛緬, 交阯一帶地方, 賊皆可出。故防之甚 難, 而剿之亦不易也。

See Cai Yurong, “Chou Dian Di Ba Shu 籌滇第八疏 (Eight Memorials Presenting Plans for Yunnan)" in Fan Chengxun, Wang Jiwen et al., Eds., 1691 Yunnan Tongzhi, juan 29, yiwen 藝文 3:36a.

83 Cai Yurong. "Chou Dian Di Ba Shu", in Fan Chengxun, Wang Jiwen et al., Eds., 1691 Yunnan Tongzhi, juan 29, yiwen 藝文 3:35b-39b. The original reads: “縱賊四 出, 每村給一木刻, 派定保頭銀十數兩, 二, 三十兩不等, 豬羊雞酒, 索取無 厭, 稍有不遂, 劫殺隨之。於是, 流離之民暨相近野賊之民樂於附賊為盜。八 年之久，招集亡命愈多，全滇各府州縣村莊聽其索保者十之八，九。”

84 Guoli Gugong Bowuguanyuan, Ed., Gongzhongdang Yongzheng Chao Zouzhe, Vol. 2, pp. 498-499. The original reads:

哀牢一山, 各州縣營汛環其三面, 其西南一面, 則係威遠土州, 鎮沅土府及 車里宣慰司之地。而威遠尤當衝要。賊人無事之時, 與土司及其子弟頭人 皆結婚姻, 或拜爲父子, 或盟爲兄弟, 一經有事, 官兵三面進攻, 賊師從土 司一面迯出, 土司師行護庇藏匿, 或縦出境外煙瘴之地, 令官兵難以前徃査 捕。督撫亦徃徃以曠日持久, 恐干処分, 姑以免罪招安。且了目前之局, 而 此輩借此一招復歸内地仍前害民。皆因從前不肯直窮到底, 是以貽串至今。

85 Kataoka Tatsuki (2013), pp. 69-94.

86 Nathan Badenoch and Tomita Shinsuke (2013), pp. 29-67, and Christian Daniels (2013), "Blocking the Path of Feral Pigs with Rotten Bamboo", pp. 133-170.

87 Regarding the foundation of the Duan Family Administrator, see Christian Daniels (2018), pp. 69-111.

88 Lian Ruizhi (2015), pp. 19-56.

89 This viewpoint originated with Ho Ping-ti (1955), pp. 191-201.

90 Nomoto Takashi and Nishikawa Kazutaka (2008), pp. 15-34. 


\section{Bibliography}

Badenoch, Nathan, and Tomita Shinsuke 富田晉助. “Mountain People in the Muang: Creation and Governance of a Tai polity in Northern Laos". Southeast Asian Studies, Vol. 2, No. 1 (2013), pp. 29-67.

Baoshan Shi Wenhua Guangdian Xinwen Chubanju 保山市文化廣電新聞出版局, Ed., Baoshan Beike 保山碑刻. Kunming: Yunnan Chuban Jituan Gongsi Yunnan Meishu Chubanshe 雲南出版集團公司雲南美術出版社, 2008.

Bryson, Megan. Goddess on the Frontier: Religion, Ethnicity and Gender in Southwest China. Stanford: Stanford University Press, 2017.

Chen Shou 陳壽. Pei Songzhi 裴松之, Annotater. Sanguo Zhi 三國志. Beijing: Zhonghua Shuju, 1982.

Daniels, Christian. "Yōsei 7 Nen Shinchō ni yoru Shipusonpanna Ohkoku no Chokkatsuchika ni Tsuite: Tai Kei Minzoku Ohkoku wo Yurugasu Sanchimin ni Kansuru Ichi Kōsatsu 雍正七年清朝によるシプソンパンナ一王国の直轄地化についてータイ 系民族王国を摇るがす山地民に関する一考察 (The Annexation of Sipsong Panna by the Qing Dynasty in 1729: An Examination of Hill Peoples Who Rocked the Foundations of a Tai Kingdom)”. Tōyōshi Kenkyū 東洋史研究, Vol. 62, No.4 (2004), pp. 694-728.

Daniels, Christian. "Historical Memories of a Chinese Adventurer in a Tay Chronicle: Usurpation of the Throne of a Tay Polity in Yunnan, 1573-1584". International Journal of Asian Studies, Vol. 3 (2006), pp. 21-48.

Daniels, Christian. "Introduction: Upland Peoples in the Making of History in Northern Continental Southeast Asia." Southeast Asian Studies, Vol. 2, No. 1 (April 2013), pp. 5-27.

Daniels, Christian. "Blocking the Path of Feral Pigs with Rotten Bamboo: The Role of Upland Peoples in the Crisis of a Tay Polity in Southwest Yunnan, 1792 to 1836". Southeast Asian Studies, Vol. 2, No. 1 (April 2013), pp. 133-170.

Daniels, Christian. "The Mongol-Yuan in Yunnan and ProtoTai/Tai Polities during the 13th-14th Century". Journal of the Siam Society, Vol. 106 (2018), pp. 69-111.

Daniels, Christian. "Upland Peoples and the 1729 Qing Annexation of the Tai Polity of Sipsong Panna, Yunnan: Disintegration from the Periphery". In Geoff Wade, Ed., China and Southeast Asia: Historical Interactions. London and New York: Routledge, 2019, pp. 188-217.

Fan Chengxun 范承勳, Wang Jiwen 王繼文 et al., Eds. 1691 Yunnan Tongzhi 雲南通志 (The Comprehensive Gazetteer of Yunnan). Citations from original edition held at Tōyō Bunko 東洋文庫, Tokyo, Japan.

Faure, David. "The Yao Wars in the Mid-Ming and Their Impact on Yao Ethnicity". In Pamela Kyle Crossley, Helen F. Siu, and Donald Sutton, Empire at the Margins: Culture, Ethnicity, and Frontier in Early Modern China. Berkeley and Los Angeles: University of California Press, 2006, pp. 171-189.

Guoli Gugong Bowuguanyuan 國立故宮博物館院 (National Palace Museum), Ed. Gongzhongdang Yongzheng Chao Zouzhe 宮中檔雍正朝奏摺 (Secret Palace Memorials of the Yongzheng Period). Taibei: National Palace Museum Press, 1988.

He Mengchun 何孟春. He Wenjian Shuyi 何文疏議. Wang Taiyue 王太岳 et al., Eds. Wenyuange Qinding Siku Quanshu 文淵閣欽定四庫全. Taibei: Taiwan Shangwu Yinshuguan, 1986.

Herman, John E. Amid the Clouds and Mist: China's Colonisation of Guizhou, 1200-1700. Cambridge and London: Harvard University Asia Center, 2007.

Ho Ping-ti. "The Introduction of American Food Plants into China". American Anthropologist, Vol. 57, No. 2 (1955), pp. 191-201. 
Hou Chong 侯冲. Baizu Xinshi: “Bai Gu Tongji” Yanjiu 白族心史一《白古通記》研究. Kunming: Yunnan Minzu Chubanshe, 2002.

Huang Shi 黃道, Ed. Huangshi Yishu Kao 黃氏逸書考. Xuxiu Siku Quanshu 續修四庫 全書. Shanghai: Shanghai Guji Chubanshe, 2002.

Kataoka Tatsuki 片岡樹. "Becoming Stateless: Historical Experience and Its Reflection on the Concept of State among the Lahu in Yunnan and Mainland Southeast Asian Massif'. Southeast Asian Studies, Vol. 2, No. 1 (2013), pp. 1-26.

Leach, E. R. Political Systems of Highland Burma: A Study of Kachin Social Structure. London: The London School of Economics and Political Science and G. Bell and Sons Ltd, 1954.

Li Ling 李零, Translator and Annotater. Sunzi Bingfa Yizhu 孫子兵法譯注. Shijiazhuang: Hebei Renmin Chubanshe, 1992.

Li Yuanyang 李元陽. Wanli Yunnan Tongzhi 萬曆雲南通志. Beijing: Zhongguo Wenlian Chubanshe 中國文聯出版社, 2011.

Lian Ruizhi 連瑞枝. “Tuqiu, Daofei Yu Bianmin: Yi Yunnan Shanxiang Yimin Wei Hexin De Taolun 土酋，盜匪與編民一以雲南山鄉夷民為核心的討論 (Ethnic Leaders, Bandits and Registered Populations: A Discussion Centred on the Upland Nonregistered People of Yunnan)". Lishi Renleixue Xuekan, 歷史人類學學刊, Vol. 13, No. 1 (2015), pp. 46-51.

Lian Ruizhi 連瑞枝. “Shuxie ‘Xinan’: Liangzhong Dianfan Lishi De Duihua Yu Jiangou 書寫「西南一兩種典範歷史的對話與建構」 (Writing Histories of the Southwest: Reconstruction and Dialogue between Two Paradigms of History)". Lishi Renleixue Kan 歷史人類學刊, Vol. 16, No. 1 (2018), pp. 39-70.

Luo Guanzhong 羅貫中. Sanguo Yanyi 三國演義. Shanghai: Zhonghua Shuju and Shanghai Guji Chubanshe, 1989.

Ma Jianxiong. "Zhaozhou Bazi Society in Yunnan: Historical Process in the Bazi Basin Environmental System during the Ming period (1368-1643)". In Ts'ui-jung Liu, Ed., Environmental History in East Asia: Interdisciplinary Perspectives. London: Routledge, 2014, pp. 131-155.

Ma Jianxiong 馬健雄. “Mingdai De Zhaozhou Yu Tiesuoqing: Dianxi Yi 'Bazi' Wei Zhongxin De Dili Huanjing Yu Zuqun Jiangou 明代的趙州與鐵索箐: 滇西以 ‘壩子' 為中心的地理環境與族群建構 (Zhaozhou and Iron Chain Gorge in the Ming Period: the Geographical Environment of Basins and the Making of Ethnic Groups in Western Yunnan)”. In Zhao Min 趙敏 and Wang Wei 王維, Eds., Dali Minzu Wenhua Yanjiu Luncong 大理民族文化研究論叢 (Collected Research Articles on Dali Ethnic Groups and Culture), No. 6. Beijing: Minzu Chubanshe, 2017, pp. 229-262.

Mao Qiling 毛奇齡. Mansi Hezhi 蠻司合志. Kangxi edition in Xuxiu Siku Quanshu 續修四庫全書. Shanghai: Shanghai Guji Chubanshe, 2002.

Min Hongxue 閔洪學. Fu Dian Zoucao (撫滇奏草 Drafts of Memorials While Serving as the Grand Coordinator of Yunnan). Citations from the original 1626 edition held at the Naikaku Bunko 内閣文庫, Tokyo, Japan.

Nomoto Takashi 野本敬 and Nishikawa Kazutaka 西川和孝. “Kanzoku Imin no Katsudō to Seitai Kankyō no Kaihen 漢族移民の活動と生態環境の改変 (The Activities of Han Migrants and Changes to the Ecological Environment)". In Christian Daniels, Ed., Ronshū Monsūn Ajia no Seitai Shi, Vol. 2: Chiiki no Seitai Shi 論集 モン スーンアジア の生態史, 第二巻: 地域の生態史 (Articles on the Ecological History of Monsoon Asia, Vol. 2: Regional Ecological History). Tokyo: Kobundō, 2008, pp. 15-34.

Peng Gang 彭綱 and Zhou Jifeng 周季鳳. Zhengde Yunnan Gazetteer 正德雲南志. Preface 1510 (Zhengde 5). In Tianyige Cang Mingdai Fangzhi Xuankan Xubian 天一 閣藏明代方志選刊續編, 70 \&71. Shanghai: Shanghai Shudian, 1990. 
Qu Jiusi 篗九思. Wanli Wugong Lu 萬曆武功錄. Taibei: Yiwen Yinshuguan, 1980.

Scott, James C. The Art of Not Being Governed: An Anarchist History of Upland Southeast Asia. New Haven and London: Yale University Press, 2009.

Sutton, Donald. "Violence and Ethnicity on a Qing Colonial Frontier: Customary and Statutory Law in the Eighteenth-Century Miao Pale". Modern Asian Studies, Vol. 37, No 1 (2003), pp. 41 80.

Tang Li 唐立 (Christian Daniels). Yunnan Xibu Shaoshu Minzu Gu Wenshu Ji 雲南西部 少數民族古文書集 (Old Documents Concerning the Minority Peoples of Western Yunnan: 1577 1943). Tokyo: Tokyo University of Foreign Studies Ajia Afurika Gengo Bunka Kenkyūjo 東京外國語大學アジア・アフリカ言語文化研究所, 2011.

Tang Li 唐立 (Christian Daniels). “Ming Qing Dianxi Menghua beike suo chuan shidafu yanjiu: Zhang Jinyun, Zhang Duanliang, Zhang Jushi, Zhang Chenzhao 明清滇西蒙 化碑刻所傳士大夫研究一張錦蘊 - 張端亮 - 張通栻 - 張辰照 (A Literati Family in Menghua County in Western Yunnan in the Ming/Qing Period as Portrayed in Stelae)". In Tang Li 唐立 (Christian Daniels), Ed., Ming Qing Dianxi Menghua Beike 明清滇西蒙化碑刻 (Ming and Qing Stelae from Menghua (Weishan), Western Yunnan). Tokyo: Tokyo University of Foreign Studies Research Institute for Languages and Cultures of Asia and Africa 東京外國語大學國立亞非語言文化研究 所, 2015, pp. 3-54.

Tang Li 唐立 (Christian Daniels). “Tuliu Jianzhi Diqu de tuguan shizheng: yi Dianxi Menghua Fu Zuo shi tuguan wei li 土流兼治地區的土官施政: 以滇西蒙化府左氏土 官為例”. Qingshi Luncong 清史論叢 No. 32 (2016), pp. 31-58.

Tuguan Dibu 土官底簿 (The Draft Register of Native Officials). In Sibu Quanshu Zhenben Chuji, Shibu Zhiguan Lei 四部全書珍本初集史部職官類.

Wang Song 王崧, Ed. Yunnan Beizhengzhi 雲南備徵志. Kunming: Yunnan Renmin Chubanshe, 2010. Citations from Yunnan Sheng Wenshi Yanjiuguan, Yunnan Congshu, Vol. 13.

Xiaozong Shilu 孝宗實錄. Taibei: Guoli Zhongyang Yanjiuyuan Lishi Yuyan Yanjiusuo, 1964.

Yang Shiyu 楊世鈺 and Zhang Shufang 張樹芳, Eds. Dali Congshu Jinshi Pian 大理叢 書金石篇. Beijing: Zhongguo Shehui Kexue Chubanshe, 1993. 10 volumes.

Yun Long 雲龍, Ed., Rui Zengrui 茌增瑞, Annotater. Minguo Yao'an Xianzhi 民國姚安 縣志. Kunming: Yunnan Renmin Chubanshe, 2005.

Yunnan Sheng Wenshi Yanjiuguan 雲南省文史研究館, Arranged 整理. Yunnan Congshu 雲南叢書. Beijing: Zhonghua Shuju, 2009.

Zhang Tingyu 張廷玉. Mingshi 明史. Beijing: Zhonghua Shuju, 1974.

Zhu Guozhen 朱國禎. Yongchuang Xiaopin 湧幢小品. Beijing: Wenhua Yishu Chubanshe, 1998, Postscript ( $b a$ 跋) dated 1622. 


\section{Index}

Page numbers in bold denote tables, those in italics denote figures.

A family: and administration of

Dengchuan sub-prefecture 46-7, 51-2; and Beisheng sub-prefecture 80; of Langqu $81-2$; of Yongning 81

A Sheng 115

A Zhe 46, 51

Achang ethnic group 34-6

administrative institutions see institutions of state control and administration

administrative reforms $60,63,65,69$ administrative units, local 47, 61, 66, 69, 76 agricultural land 47, 48, 55, 70; arable 11, 51; misappropriation of 29

Ai Zixiu 50-1, 52-4; history of Dali area 56-7; on the lijia system 60-1

Ailao mountain range 162, 164 ancestor worship 14-15

Anning Salt Well 22, 24, 25

Art of Not Being Governed, The (Scott)

137,161

Ashoka (Indian emperor) 53

autonomous communities 137, 139-40; in Iron Chain Gorge 138-9

Autumn Sacrifice (qiushe) 60

Avalokiteśvara 15-16n17, 55, 126; worship 7

Avatamsaka Sūtra (Flower Garden Sutra) 7, 126

Ayeyarwaddy River 5, 10, 15n8

'Ba' ri tribe 114

Ba'er family 114

Bai erzi (sons of Bai) 53

Bai Gu Tongji 141, 169n15

Bai people 6,15n12, 138, 147; origins of 53-4; see also Minjia people

Baisha village 122, 125, 126-7
Baiya dian 161

banditry 92, 101; in Binchuan gorges 153-5, 159; in Iron Chain Gorge 84-5, 149; in Lukui Mountain 162-3, 174n82; in Muli region 133n30; and native officials 164; and Naxi King 117; and upland communities 139, 156, 157-8, 166

baojia system of collective responsibility 8,61

barbarians $6,39,58,160$; yi yi zhi yi policy 90; see also Tibetans (Tubo)

Beisheng sub-prefecture 76, 77-9, 105n3; Confucian school in 96; Han migration into 94-5, 104; Jiangxi merchants in 95; and Lancang Guard 105; walled city of 86

Biaoleng Temple 55, 65

Binchuan sub-prefecture 146, 148-9; banditry in 159-60

Biographies of Luo Si and the Various Barbarians of Iron Chain Gorge 142, 145, 147, 171n46; and Zou Yinglong offensive 150

Biographies of Six Masters of the Mu Family. (Feng Shike) 112

bKa 'brGyud pa (GB) 112, 120; and Jang edition of the Tibetan bka' 'gyur 121-2; and Karmapa sect and Mu Native Official 123-4; and Karmapa sect visits to Lijiang 125-6

bka' 'gyur 120-3, 124, 125, 127-8, 130-1, $132 \mathrm{n} 10$

Black Hat Karmapa incarnate Lama 120, 126

Black Salt Well 20, 22, 24, 25

Bo people 53

borders, unrest on 19, 77, 83, 90, 102, 120

Bowen writing 4 
Bryson, Megan 6; on Buddhism in Dali kingdom 7; on Li Yuanyang 141-2

$\mathrm{Bu}$ bai $\mathrm{Ru}$ Jia rebellion 84

Buddha and Hāriti 57-8

Buddha statues and Taliu people 102-3

Buddharājas 15-16n17; worship 6, 7-8

Buddhism 4, 64, 112; in Dali area 54-5, 56; and Li Yuanyang 141; pre-1382 6-8; see also Tibetan Buddhism

Buddhist monasteries: decline of 60, 65, 66-7; family sponsorship of 55, 56; and Gao family 50

Buddhist temples 54-5, 102-3, 141

Burma 14, 46, 52; immigrants from 54; and Lancang Guard 93

Cai Yurong 163, 174n82

caitya worship (zhiti xinyang) 7

canal construction 48

Caojian 32, 36-7

centre-local dichotomy 1, 2, 13

chastity cult 142

chastity martyrdom ( jilie) 58, 59

Chen Biao 97

Chen Taliu family 103

Chongshen temple 141

Chos byung mKhas pa'i dGa' sTon

(KPGT) 112, 120, 123

Chos kyi rGyal mTshan 120, 122

Chuandeng Temple 102

Cibi Lake 65

Cishan, Madame, tale of 56-9, 141-2

Cishan Temple, Ai Zixiu history of 56

civil service examinations 30, 64, 96-7

civilian tax-paying households (minhu) $8-9,47$

civilianisation (minhua) of soldiers 100

civilising projects 6

climate in Yunnan basins 44-5

colonisation 2, 6

Commissioner for Salt Transit Taxes

(Yanque Shi) 20

common property $14-15,43,65-6,69,70$, 71 ; water mill in Dengchuan basin 68; wet fields (gongtian) 67

communication routes: in Lancang Guard jurisdiction 87, 93-4, 99; and Taliu people 102; and transformation of local society 100

Community Covenant Elder (xiangyue laoren) 61

Comprehensive Gazetteer of Yunnan (Li Yuanyang) 32, 99
Confucian elite: emergence of 4, 6; and social reconstruction $166,168 \mathrm{n} 5$

Confucianism: civilising mission 6 ; education 96-7; ideology 8, 58, 59, 64; see also Neo-Confucianism

conscription $11,50,108 \mathrm{n} 100$

consecration ceremonies (abhiseka) 125, 126,127

cooperative village projects $65-8,69-70$

corruption and grain supply to the military 28-9

county magistrates 60 ; and irrigation 45-6; and river management 48

cremation, prohibition of 64

Cuan people 53, 147

cultural identity $43-4$

Dabaoji palace 126

Dade Temple 102-3

Dajue palace 126

Dalai Lama see Third Dalai Lama

Dali kingdom 2-3, 50, 137; Bai people 6; and Buddhism 6-7; land ownership 65; transition to Ming rule 4-5

Dali prefecture: corruption and food supply to the military 28 ; and salt production 30

Dali region 49

Daluo Guard 146, 160, 169-70n27

Dao Ai (Tai leader) 51, 53

Daoist priests 61, 64

Dazang Jiao Xu 112, 132n10

Dazangjing $X u$ 122-3, 127

deforestation in Langqiong 48

Dengchuan basin 44, 45; irrigation systems 46,66

Dengchuan county 46-7; social reforms 47-8

Dengchuan sub-prefecture and A family 51-2

Deyuan city, tale of 56-7

dharma: and dragons 141; and Naxi King 124-5

Dharma Guardian deities of Dali kingdom 7

Dian Zaiji (Yang Shen) 4

Dictionary of Official Titles in Imperial China (Hucker) 72n15, 72n16

dikes, maintenance of 48

Dong Zhen (native police chief of Zhaozhou) 28

Dongchuan Great Temple 68

Dongjing Assemblies 68

Dragon King Temple 56 
dragons 141

Du Wenxiu rebellion 14, 68, 69

Duan Bao 34-6

Duan Family General Administrator

(Duan shi zongguan) 3, 9, 50

Duan royal family 3, 6, 34, 50, 138, 167

Duan Siping and Sanchong 33-4, 35

Duan Wenxian 32-3

Duan Xingzhi (Dali King) 3

Duan Zhixing (Emperor) 7-8, 15-16n17

elites 4-5; civilising of non-Han 6; cooperation between state and local 70-1

Emperor Zhao Shanzheng (village deity) 67

Erhai Lake 44, 45, 137; and dragons 141

Eryuan county 13, 43; creation of 47; geography of 44; lowland communities in 14

ethnic communities 138; Bai 6; in Beisheng prefecture 94; and internal frontiers 147; of the lowlands 13; and the state $1-2,167$

ethnic identities: and adminstrative reforms 60; and migration 39; Taliu people 102-3; transformations in 13-14, 47, 70-1

ethnic people (yiren) 8

eunuchs 29

examination system for bureaucrats 4,64 ; and literati 60

farming and community cooperation 45

Faure, David 1, 14, 140

Feng family and Native Prefect of Wuding 146-7

Feng Jizu rebellion 146-7

Feng Su 58-9

Fengshi 55

Fengyu basin 44; irrigation systems 46

fidelity (sijie) 58

Five Constant Virtues (sangang wuchang) $59,73 n 43$

Five Military Commissions (wu jun dudu fu) 10,82

Flower Garland Sutra (Avatamsaka Sūtra) 7, 126

Foguang stockade 35, 41n39, 46, 51

food shortages 22, 157-8

$\mathrm{Fu}$ Youde (General for Conquering the South) 22, 35, 80, 83, 102

Fude Longnü/Baijie Shengfei 7

\section{gaitu guiliu 9}

Gao family 79, 82; and Beisheng subprefecture 80; and Dali area 50; dispute within 91; imperial commendations for military service 91; and Ranggong Chapel 55; and rebellions 90; tribute missions 89; and upland communities 146,147

Gao Lan 91

Gao Laoguan 50

Gao Native Official and Taliu people 102-3, 105

Gao Qizhou 164

Gao Shanggui 48

Gao Zhisheng 80

Gar dBang chos kyi dBang phyug 120; and Jang edition of the Tibetan bka' 'gyur 121-2, 123; and Mu Zeng 127-8; and Naxi King 125-6

Gazetteer of Chicken Foot Mountain 124

Gazetteer of Dengchuan Sub-prefecture (Ai Zixiu) 52, 54

gazetteer of Yunnan 79, 94, 97, 98, 160

genealogies and social history 103

gentry 43, 54; and administrative reforms

65; and common property management

69; and local communities 70;

monastery court case against 66-7;

promotion to through Confucian education 97; and transformation of local society $56,63-4$; and water management $67-8$

grain: demand for 11; production of and military families 51 ; supply of 10,12 , 19, 21, 22, 26-7, 38, 145; and upland communities 154,158

grain to salt exchange rate 20,21 , 24-6, 38

Great Righteousness (gangchang dayi) 58,59

Great Vine Gorge 140

Gu Zuyu on Iron Chain Gorge 84-5

Guangzhi Yi (Wang Shixing) 88, 93

Guanyin Gorge 98

Guards and Battalions (weisuo) 53, 72n15, 76; abolition of 59; in basin communities 47-8; and control of borders 19, 83, 100; decline of 12-13, 101-2, 105; establishment of 9-11, 19, $82-3,87-8$; and farming 51 ; and internal frontiers 159-60, 167; supplying grain to $21,22,26-7,38$; and transformation of local society 104, 137-8; see also Lancang Guard; Daluo Guard guest migrants 53

Guizhou province 2, 94, 137, 139, 146 
Han colonisation 6

Han migrants 11-12, 15, 138; to Beisheng sub-prefecture 104; and Guards and Battalions (weisuo) 76; and internal frontiers 167-8; and Taliu people 102; troops from Central China 22-3, 52-3; to Yunlong county 30

Han people 13, 63, 70; classification of 53,54

Han-Jin Chunqiu (Spring and Autumn between the Han and Jin Periods) (Xi Zaochi) 145

Hāriti 57-8, 59

He Mengchun (Grand Coordinator of Yunnan) 29, 141, 156

Heqing prefecture 62, 80-1, 100-1; destruction of temples in 64

Historical Anthropology of Chinese Society project 1

horses as tribute $31,89-90$

Hou Chong 6, 169n15; and Bai identity 15n12, 141; on Buddhism in Dali kingdom 7

household registration $13,47,59,69,138$; in Iron Chain Gorge 140; reform of 53; and upland communities 140

$\mathrm{Hu}$ Yuan (Commander of the Jinchi Guard) 29

Hucker, Charles O. 72n15, 72n16

Huikang Temple 55, 67

humanistic learning (renwen) 96

Hunan province 137, 139, 169n10

imperial bureaucrats: and inaction against bandits 160-1; and Lukui Mountain 162-4; and upland communities 138 , 145-6, 152, 156, 157-9; and Zou Yinglong offensive 150; see also native officials (tuguan)

indigenous people (turen) 1-2, 39, 52-3, 69, 94; cheated by Jiangxi merchants 95; and Confucian education 96-7; and Guards and Battalions (weisuo) 19, 76-7, 98-102, 103, 105; revolts by $83-6,90$, 144-5; and salt 20; sinicisation of 13 ; and state governance 8-9, 32, 104; see also Bai people; Cuan people; Minjia people; Tai people; Taliu people; Xifan people inflation in food prices 26, 27

institutions of state control and administration 8, 150-2, 165-6; and basin communities 47; failure of on internal frontiers 154-5; and internal frontiers $156,162-8$ intermarriage 69; between Lancang Guard and indigenous people 103, 105; between native official families in northwest Yunnan 82; between upland bandits and native officials 164

internal frontier areas 140, 143, 162; and banditry $153-5,164-5$; and Han migration 167-8; Iron Chain Gorge 8, 10, 137-8; leaders within 147-8, 148; and salt trade 158; and state bureaucrats 145-6; and state institutions 150; and the Ten Kings 142; and upland communities 166

Iron Chain Gorge 84-5, 89, 137-9, 139, $152,153,162,168 \mathrm{n} 3$; autonomous communities 5, 8; campaigns against bandits in 149-50; community leaders 164-5; ethnic communities of 147-8; raids on lowlands 153-4; and state governance 140, 166-7

Irrawaddy River see Ayeyarwaddy River irrigation systems 43, 45-6; Lancang Guard projects 98; village agreements 67; and village temples 65-6

'Jam dByang bZang po see Lama 'Jam dByang bZang po

'Jang bar bKa' 'gyur 111, 112

Jang edition of the Tibetan bka' 'gyur $120-3,124,125$

'jang sa dam rgyal po see Naxi King of Lijiang

'Jang villages see Naxi villages

Jia Hala rebellion 84

Jigudian shuoji (Collected Records of Ancient Dian Stories) (Zhang Daozong) 141

Jinbang Temple and Madame Cishan 57

Jinchi Guard 29

Jingtai gazetteer of Yunnan 79, 94, 97

Jinjiang Ferry 86

Jinsha River 77, 78, 79, 131n2

Jinsha River Fort 86

Jiuqitai hot spring $68-9$

Jiuzhou 32-3, 33, 36, 38

Jizu (mountain and deity) 33, 35, 39

Kachin societies 14

Kar 'Jang 116-18

Karmapa sect 111, 112, 115-16; and donations 124-5; and $\mathrm{Mu}$ Native Official 120; and Mu Native Official as sponsor 129-30; promotion of under Naxi King 118; and temples 123-4; see also Kar 'Jang 
Kataoka Tatsuki 165

Kham region (eastern Tibet) 111, 113, 114-20, 123-5, 129-31

King of White Rice, the 53

Kirigaya, Ken $15 \mathrm{n} 8$

Ku Chengmei 7-8, 15-16n17

Kublai Khan 86

Labour Management Elder (guangong laoren) 61

Lai Xun (Surveillance Commissioner of Yunnan) 27

Lama 'Jam dByang bZang po 114; and taxation 119

Lama Sanggyes Gyatso 116

Lama Sangs rGyas rGya mTsho 116

Lancang Guard 10, 79, 80-1; area of jurisdiction 88; case of failure to defend against bandits 92; and Confucian education 96, 97; establishment of 86; ethnic composition of 94; extent of operations 93; farming and irrigation 98; and integration to form Taliu people 103, 105; and local communities 12-13, 88-9, 100, 104; marriage alliances 91; role of 76-7

land ownership 65,70

land registration for tax 15

Langqiong basin 44; Biaoleng Temple and land ownership 65; irrigation systems 46-7, 66-7; village temples in 55-6; water management agreements 67

Langqiong county 30 ; social reforms 48 , $50-1,55$

Langqiong sub-prefecture 62-3; see also Biaoleng Temple

Langqu sub-prefecture 81-2; tribute missions by native officials $89-90$

Lanruo Temple 66

Leach, Edmund 14

li captains (lishang) 61

li Elders (lilao) 61

Li Guanzhang 34

Li Shao on Lancang Guard's failure against banditry $92-3$

Li the Immortal 142, 149

Li Yuanyang 4, 32, 63, 141-2, 169n13, $170 n 41$; on banditry $153-4,156$; collected works 169n12; on Confucian education in Beisheng sub-prefecture 96; on Cuan people 147; on imperial bureaucrats 161; on Iron Chain Gorge 85; and Ranggong Chapel 55; Record of Pacifying the Bandits at the Tiesuo
River 155; Record of Quelling the Bandits of Binchuan, A 158-9; Record of the Earth-walled City of Baiya 161; on salt 157; and state bureaucrats 150-2 Li Zhongxi Quanji (Li Yuanyang) 169n12 Lian Ruizhi 140, 142, 146, 154, 167 lijia system of social control and taxation 4, 8, 59, 60-1, 69, 72n16; and basin communities 47; in Eryuan county 13; in Iron Chain Gorge 140; Single Whip (yitiao bianfa) reforms 61-2; and upland communities 166; and villages 66

Lijiang Ban Ganzhuer 111

Lijiang prefecture $80,82,100-1,113,114$; Buddhist structures in 125-7; Karmapa sect lama visit 123-4; and Tibetan bka' 'gyur $127-8$

lineages and kinship 14-15, 44, 103, 105

Lingjiu temple 55

Lingying Temple 55

Lisu rebellion $37,41 \mathrm{n} 44$

literati 43, 140-2; and administrative reforms 65; Confucian 60; and Madame Cishan 57-9; and monasteries 66; and moral instruction 63, 70; re-writing of old texts 59

Liu Sishan 97

Liu Xi 97

local communities 12; and common property management 69 ; and cultural identity 4, 43-4; and geography 5-6; and Guards and Battalions (weisuo) 76; and social reforms $70-1$; and state institutions 8, 88-9

local deities: Dali kingdom 7; re-interpretation of 56; see also Emperor Zhao Shanzheng (village deity); Sanchong (tutelary deity in Yunlong); State Founding Chicken Foot Emperor (Jianguo Jizu Huangdi) (Wujing deity)

local elites: composition of 43; and Confucian education 97; and cultural changes 4, 138, 142; and internal frontiers 166; and the state 1-2; and Taliu people 104

local magnates (yihao) 38-9; and grain supply shortages $12,28,32$; and indigenous people 39 ; monopoly on salt licences 26; official status aspirations $30-1$; state use of 32

local society: Ai Zixiu classification 52; collective responsibility 61; and Guards and Battalions (weisuo) 105; and influx of military personnel 50; Lancang Guard 
and transformation of in Beisheng 76-7, 104; and lijia system 60; and markets 99-100; and migration 62-3; and role of the gentry in transformation 54-6; and salt-barter system 19, 29-32; state policies and transformations in 38-9, 69-70, 71, 142; structure of 94; transformation through virtue (dehua) 97

Longhua Temple 55

lowland communities 138 ; and banditry 154-5, 159; and Guards and Battalions (weisuo) 146; and protection silver $163-4,165$

lowland/upland dichotomy 5-6, 13, 137

lowland-upland exchange 154, 156-7

Lukui Mountain 162-5, 174n82

Luo Ge 142-4

Luo Qinkuai 142, 146, 149

Luo Si 142-4, 146

Luochuan basin 51-2

Luofu Temple 55

Luoluo people 13, 54, 70, 147, 160; and Lukui Mountain 162-5

Luoma salt well 38

magnates (haoyou) 26; and Biaoleng Temple 65; see also local magnates (yihao)

Mahākāla 7

maize cultivation 167

Mäng Maaw; Tai polity of 10-11; campaigns against and grain supply to the military 22-6, 27-8; war against 19, 32, 38, 90

Mao Sheng (eunuch) 29

markets 99, 157-8

Mekong River 33, 33, 34, 44, 49, 78

Meng Huo (indigenous leader) 144-5

merchants: and banditry $85,172 \mathrm{n} 56$; and local communities in Beisheng subprefecture 95; migrant 38, 39, 104; Muslim 54; and salt-barter system 12, 20-2, 24-7, 30

Mi bsKod rDo rJe 123

Mi De 118

migration 39, 52-4, 69, 130; see also Han migrants

Miju River 45; and irrigation 44, 45, 48

Military Defence Vice-Commissioner, appointment of at Lancang 92-3

military dereliction of duty 94

military discipline 92

military family members (sheren) $50-1$; and reform of household registration 53 military farming colonies (juntun) 11,
$16 \mathrm{n} 25,19,76$; and communication route forts 77 ; and delivery of grain (baozhong) 26-7; and Lancang Guard 98-9; misappropriation of 28; and salt-barter system 21

military governance 88

military households (junhu) 8, 47-8; and

Dengchuan basin 68; integration into local society 52; and Langqiong basin 50-1; and reform of household registration 53

military service, imperial commendations for 91

military strategy 144-5

Military-cum-Civilian Military Command: and Jinchi Guard 29; and Lancang Guard 79, 88, 100

Min Hongxue (Grand Coordinator of Yunnan) 174n81

Ming History 21, 31; on Beisheng sub-prefecture 79; on hereditary native officials 89; on Iron Chain Gorge 84; on Lancang Guard 88; on Lijiang native officials' tribute mission 89-90; on $\mathrm{Mu}$ De's reward for meritorious service 91; on $\mathrm{Mu}$ Zeng's punitive mission against Gao Lan 91; on Wang Ji 34

Ming Huiyao 31

Ming Shi see Ming History

Mingguang 36

mining $54,62-3$

Ministry of Revenue and grain to salt exchange rate $20,22,24$

Minjia people 13-14, 63, 70

Mongolians 86

Mongol-Yuan 2-3, 138; administration 19, 50 ; extent of territory 10 ; and $\mathrm{Li}$ Yuanyang 141; native officials (tuguan) in northwest Yunnan 80-2; and salt production 20; transition to Ming rule 31; and Zao dynasty 34

monsoon 45, 66

$\mathrm{Mu}$ Ang (General for Conquering the South) 25

$\mathrm{Mu}$ Chun (Marquis of Pacifying the West) 100-1

Mu Dong (Native Official) 82, 115, 120

Mu family 51 ; annexation of territory by 111; area of jurisdiction $80-1$; and Beisheng sub-prefecture 79-80; imperial commendations for military service 91 ; manors controlled by 51 ; military campaigns against Muli 114-16, 
131-2n3; and rebellions 90-1; tribute missions 89-90

Mu li chos byung (MC) 112, 115, 119, 133n27; on 'Ba' ri 114; on Kar 'Jang 117; on Naxi King destruction of temples 116

Mu Native Official 111, 115; and Jang edition of the Tibetan bka' 'gyur 121; and Karmapa sect 120, 123-4, 126-7, 129-31; and taxation of villages 119-20, 124-5; see also Naxi King of Lijiang

$\mathrm{Mu}$ residence (Mu Fu) 126, 129

Mu Shi Huanpu (MH) see Mushi Huanpu (MH)

Mu Shi Liugong Zhuan 115, 117

Mu Zeng (Native Official) 91, 112, 124, 127-8

Muli region 113, 114, 132n9; and Lama Sanggyes Gyatso 116; Mu family military campaigns in 114-15; and Naxi King of Lijiang governance 117-18; taxation by Naxi King 118-19

Mushi Huanpu (MH) 82, 90, 91, 112, 114-15, 124, 133n30

Myanmar see Burma

Nanzhao kingdom 46; and Buddhist temples 55; and Dali area 56-7; and salt production 20

Nanzhong and the Ten Kings 142-5

Native Official of Yunlong 34-6

native officials (tuguan) 8-9, 51, 76, 138; advancement for military success 91 ; and Confucian education 96; and decline of Guards and Battalions 12-13; A family 60; A family in Dengchuan 47, 51,53 ; and grain supply to the military 28; and internal frontiers 146; and Iron Chain Gorge 166-7; and local official troops 101-2; in northwest Yunnan 79-82; and regular bureaucrats 47, 51; restraint on power of 88-9, 91; and the state 1, 12-13, 19, 100; state use of $31-2,111$; tribute and state patronage 89; and tribute system $30-1$; and upland communities 5, 140, 147; use of Guard system for advancement 91; and Zou Yinglong offensive 150, 151; see also Gao Native Official and Taliu people; Mu Native Official

Native Prefect of Wuding 146-7 native troops (tubing) 140, 155, 158 Naxi ethnic group 111

Naxi King of Lijiang 115-16, 130, 133n30, 133n36; governance of Muli 117-18; and Jang edition of the Tibetan bka' 'gyur 122, 123; Karmapa sect visits to $125-6,127$; and taxation 118-19

Naxi villages $117-18$

Neo-Confucianism 52, 63, 66; and religious history 56

non-Han peoples 2, 6, 70, 94, 162

non-Han/Han distinction 13-14

non-registered communities 140, 160; see also barbarians

northwest Yunnan map 78

official appointments: and grain supply shortages to the military $27-8$; and tribute system 89

official magnates (guanhao) and nepotism 28

outposts: and banditry 101; establishment of 86-7

Pearl River Delta 140, 166

Police Offices 72n30; and A family 51

Political and Religious History of Muli, The 130

post stations 62,86

postal relay stations (yizhan) 12, 77, 86-7, 93, 102, 104; see also Qingshui postal relay station

Preface to the Tripitaka 121, 127-8

Prefectural Buddhist Registries 4

propriety (li) 96, 97

protection silver and bandits $163-4,165$

$\mathrm{Pu}$ Yandu 35

Qianlong gazetteer of Yongbei prefecture 79, 86, 90, 99; on Xifan people 99

Qing dynasty: and adminitrative reforms 63; and ethnic identity 70; and Feng Su 58-9; and Lukui Mountain upland leaders 162-4; war against Konbaung dynasty 52; Zuo family appointments in Migguang 36-7

Qingshui postal relay station 87, 95, 97, 99

rab tu gNas ritual 121-2, 123, 124, 127

Ranggong Chapel 55

rebellions by indigenous leaders $21,37-8$, 76, 83-6, 90-1, 150, 166; see also $\mathrm{Du}$ Wenxiu rebellion; Feng Jizu rebellion; Lisu rebellion

Record of Pacifying the Bandits at the Tiesuo River (Li Yuanyang) 155, 156 
Record of Quelling the Bandits of

Binchuan, A (Li Yuanyang) 158-9

Record of the Earth-walled City of Baiya 161

Red Hat Lama 120, 122, 126

Red Rock Cliff 90, 153, 168n3

Regional Military Commission ( $d u$ zhihui shi si) 10, 72n15, 82, 83, 88, 106n17

regular bureaucrats (liuguan) 2, 8-10, 13, $47,104,138$; and native officials 166-7; and salt licences 12

religion and the state 4, 39

Religious History of the Yellow Hat Sect, The $132 \mathrm{n} 23$

resources, control of 43-4, 66-7, 69-70, 104; see also common property

rGyal thang gi lo rGyus yig tshigs dByad gZhi phyogs bs Grags 112

rice cultivation see wet rice cultivation

righteousness ( $y i) 97$

ritual 43, 60-1, 68, 70, 121-2, 123, 127, 142

rKang rab can Temple 116

royalty, Buddhist concepts of 7

Ruan Jiaxiang (Magistrate of Tongchuan zhou) 97

Ruiguang Temple 97

Salt Distribution Supervisorates (Yanke

Tiju Si) 22, 26; Wujing Salt wells 30

salt licences (yanyin) 12, 21, 26

salt production $20-1,22,24-5,26,30$; and tribute system $30-1$

Salt Tax Offices (Yanke si) 30

salt-barter system (kaizhong fa) 16n32, 19, 24-7, 32, 38; and grain supply 12, 157, 158; and local communities 29-32; and military 20-2

samsāra 35

Sanchong (tutelary deity in Yunlong) 19, 33,36 ; change of identity 32 ; identified as a Han General 37-8

Sanchong Hao (ritual text) 33

Sanchong Mountain 32-3

Sanjiao Lun (Discussions on the Three Teachings) (Yang Nanjin) 63

Sanjiao Shengjiao Xu 121

Sanzang Shengjiao Xu 112, 127

sBa shes palace $122,125-7$

scholar-officials 142

Scott, James C. 137, 139, 161, 165

seasonal labour and community cooperation 46

sentry outposts 87

Shan (Tai) societies 14
Shang Guanchong punished for dereliction of duty 94

Shanxi province and salt-barter system 21

shell money and copper coins 62

Shunzhou 81; Confucian school in 96; tribute missions by native officials 89

Si Renfa (leader of Mäng Maaw) 25, 27, 37,38

Sichuan 79-80, 81, 83-5, 86, 97, 102-3, 113,146

Single Whip (yitiao bianfa) reforms 61-2

Sino-Burmese relations 52

social categories: Ai Zixiu classification 52-4; elimination under Qing reforms 63; Hou Yunqin reclassification 54

social reconstruction 4, 138, 142, 168n5; and Confucian elites 166

socio-political change 4, 8-15, 43-4, 50-2

soldiers stationed in Yunnan 11-12, 21

Songpan rebellion 83

southern Kham area 119-20, 123, 125, 129-30, 131; see also Muli region

sPom rag bKra shis rab brTan dzong mNga' 'og gi sGrig lam yig cha (PKG) 118-19, 133n35

sPom rag village 118

Spring Sacrifice (chunshe) 60

State Founding Chicken Foot Emperor (Jianguo Jizu Huangdi) (Wujing deity) 32,33

state honours: and military prowess 91 ; and tribute system 89

sulphur spring 68-9

Sun Zi Bingfa 144

Supervisor of the Salt Commission (Tiju Yanshi si) 20

Sutton, Donald 169n10

sweet potato cultivation 167

Tai ethnic group 34

Tai people 53, 60

Tai polities $10-11,15 \mathrm{n} 8$

Tai troops $51-2$

Taliu people 102-4, 105

Tan Sheng (Magistrate of Hezhou) 97

Tantric Buddhism 7

tax paying subjects $(\mathrm{min}) 138,140$

taxation 14-15, 89; in Dengchuan 60-1; by Mu Native Officials 118-19, 124-5; and salt 20,30; and silver 62; and upland communities 154

tea horse trade 79

temples see Buddhist temples; village temples 
Ten Kings 142-4, 165; and Iron Chain Gorge 148; and story of Meng Huo 145; and Zou Yinglong offensive 149

Third Dalai Lama, visit to Li thang 115-16

Three Bonds 59, 73n43

Three Pagoda Temple 55

Tibet $8,79,111$

Tibetan bka' 'gyur 127-8, 130-1; see also Jang edition of the Tibetan bka' 'gyur

Tibetan Buddhism 111, 120, 127, 130-1, 134n62; temples in Muli region $116-17,123$

Tibetan lama sects see Karmapa sect; Yellow Hats sect (dGe lugs pa)

Tibetan Tripitaka 111

Tibetans (Tubo) 8, 79, 86, 91, 111-12, 114; and Muli region 114, 115-18; and taxation of villages $118-20$

Tounggoo military attacks 52; and Lancang Guard 93

trade and transportation routes $5-6,15 \mathrm{n} 8$, 77, 157; Dengchuan sub-prefecture and Heqing prefecture 62; Sichuan and Tibet 79 ; and wet rice cultivation 44

tribute missions 89-90, 92; and foreign envoys 93

tribute system $30-1,89$

Tripitaka 7, 111, 121, 127-8, 130, 133n46 tuliu jianzhi administrative arrangement 9, 47

Tumu Crisis (1449) 12

Tuzhu Bian (Local Change) (Yang Nanjin) 63-4

upland communities 5, 158, 161, 165; Biographies of Luo Si and the Various Barbarians of Iron Chain Gorge 142; and food shortages 157-8; grain supplies to 154; Iron Chain Gorge 137; leaders of in Lukui Mountain 162-4; and markets 99-100; political power in 144; and salt-barter system 157-8; and the state 8 ; and state governance 140 , $150-2,156,166-7$

uplands, extent of 44

Upper Ditch of the Changle Village God 65,66

using barbarians to control barbarians ( $y i$ yi zhi yi) 90, 167

Vairocana Buddha 7-8, 15-16n17 valley basins 5-6; of Eryuan county 44 Veritable Records of the Ming, The 16n25, 30,83 ; on indigenous rebellions 86 ; $\mathrm{Li}$ Shao's memorial on Lancang Guard 92-3; on military dereliction of duty 92 ; on Military-cum-Civilian Command 100; on tribute missions 89-90

Veritable Records of the Xiaozong Emperor 160

village leaders $14,15,43,69,70$

village temples 44, 55-6; and cooperative projects 69-70; and land ownership 65-9; and local communities 59, 71; see also Buddhist temples

Wang Ji (deified Minister of War) 4, 32, 39; Caojian legend of 36; replaces Duan Siping 34; Yunlong sub-prefecture gazetteer legend 37-8

Wang Shixing (Military Defence Vice-Commissioner of Lancang Guard) 88, 93, 95

Wang Song (Langqiong scholar) 64-5

Wang Yi memorial on Confucian schools 96

Wang Zuo (Lancang Guard Commander) 86 Wanli reign period 47-8, 60; and Lanruo Temple incident 66-7

Wanli Wugong Lu 142, 169n19

water management 43; and Cibi Lake villages 65 ; and common property 69 ; Dengchuan basin 68; and Guanyin Gorge 98; Langqiong basin 67; metaphor for social change 63-4; and Miju River 48; and village temples 56 Western Yunnan map 23 wet fields (gongtian) 98 wet rice cultivation 44-6; and banditry 155; and village temples 65-7

White Salt Well 24, 25

woodblocks for bka' 'gyur 120-1, 122, $124,125,127-8$

Woodcutter Blue (Qiaoqingshen) (village deity) 67

Wooden Bell Elder (muduo laoren) 61

Wu Sangui 58-9, 62, 162, 163

Wujing Salt wells 25, 26, 29-30; local magnates (yihao) and local deity 32; Wang Ji (deified Minister of War) worshipped at 32

\section{Xi Zaochi 145}

Xiao Jin 160

Xiaozong Shilu 169-70n27

Xifan people 99, 114

Xingci Temple 55

Xinping county $162,174 n 81$ 
Xixinquan Bei (Spring for Washing Hearts Stele) (Yang Nanjin) 63

Xu Hongzu (Ming geographer) 114, $134 \mathrm{n} 60$

Yalong River 116, 117, 131n2

Yang Ci history of Jinbang Temple 57

Yang Nanjin 63-4

Yang Ning (Right Vice-Minister) 96, 101

Yang Nu rebellions 83

Yang Shen (scholar-official) 4, 63, 157-8

Yang Shiyun (scholar-official) 4, 142

Yang Zongzhou (Native Official) 162-3

Yangtze River 5

Yanjing Guard 117

Yellow Hats sect (dGe lugs pa) 115-16, 130,131 ; suppression of 118

yi yi zhi yi policy 90,167

Yingzong Emperor 25

Yongning sub-prefecture 81 ; rebellions by indigenous leaders in 84

Yuefeng 52

Yun-Gui plateau 44

Yunlong Ji Wang (Dong Shanqing) 34, 35, 39, 40n35

Yunlong sub-prefecture 4-5, 19, 33; and Sanchong deity $32-3$; and state institutions 12

Yunlong sub-prefecture gazetteer and legend of Shanchong and Wang Ji 37-8

Yunnan Provincial Administration

Commissioner 21, 100; and grain supply shortages $24-5,27$
Yushi Mine 62-3

Zao Bao 34, 35

Zao family $34-5$

Zao Kai dynasty in Yunlong 34

Zhang Dan 65, 83-4

Zhang family and Beisheng sub-prefecture 80

Zhang Guanyin $\mathrm{Nu} 89$

Zhang Jing 55

Zhang Lining 103

Zhang Shengwen Fanhua Juan 7 , 15-16n17

Zhao Shanzheng 55, 67

Zheng Chun 20

Zhengde Yunnan Gazetteer 11, 98, 101

Zhu Geliang 52-3; and Meng Huo 144-5

Zhu Guozhen 141

Zhu Yuanzhang 19, 138, 167; and Confucian education of native leaders' sons 96 ; and grain supply to the military 20-1; and Guards and Battalions (weisuo) 9, 11, 76, 82-3; and Lijiang prefecture 80

Zi family: and rebellions 90; and Shunzhou 81

Zomia region 137

Zou Lü punished for dereliction of duty 94

Zou Yinglong and military campaign $1573 / 74,142,149-50$

Zuo family $36-7$

Zuo Zhengbang 37, 41n44 


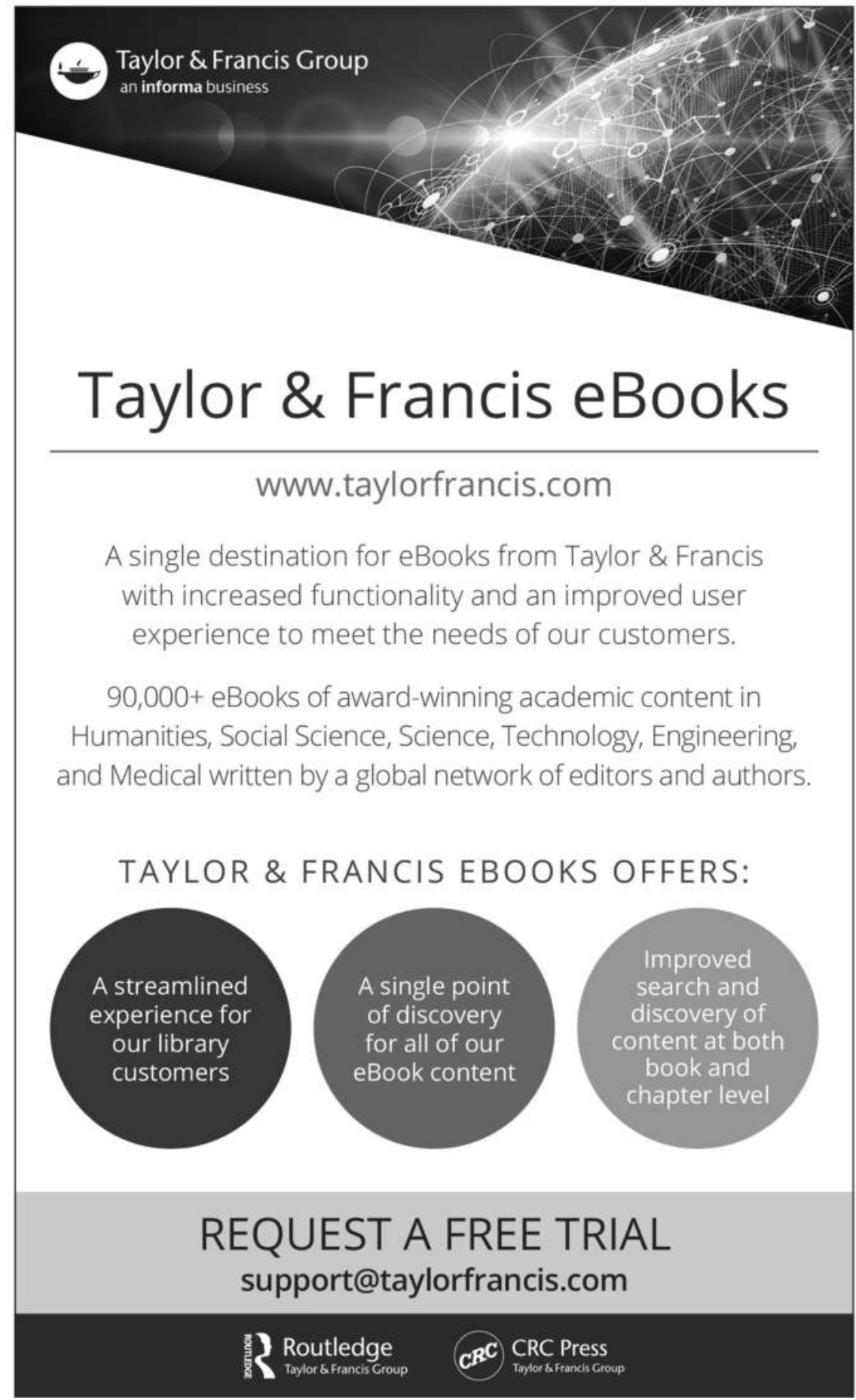

